International Labour Conference, 92nd Session, 2004

Report VI

\title{
Towards a fair deal for migrant workers in the global economy
}

Sixth item on the agenda

International Labour Office Geneva 
ISBN 92-2-113043-6

ISSN 0074-6681

First edition 2004

The designations employed in ILO publications, which are in conformity with United Nations practice, and the presentation of material therein do not imply the expression of any opinion whatsoever on the part of the International Labour Office concerning the legal status of any country, area or territory or of its authorities, or concerning the delimitation of its frontiers.

Reference to names of firms and commercial products and processes does not imply their endorsement by the International Labour Office, and any failure to mention a particular firm, commercial product or process is not a sign of disapproval.

ILO publications can be obtained through major booksellers or ILO local offices in many countries, or direct from ILO Publications, International Labour Office, CH-1211 Geneva 22, Switzerland. Catalogues or lists of new publications are available free of charge from the above address, or by email: pubvente@ilo.org Visit our web site: www.ilo.org/publns 


\section{Contents}

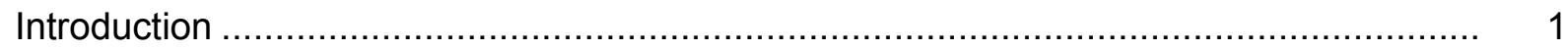

Chapter 1. Labour migration in a globalizing world .................................................... 3

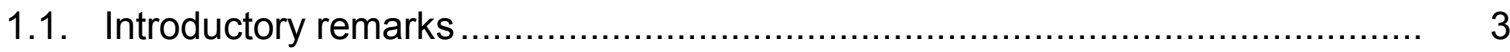

1.2. Growth of labour migration ................................................................. 5

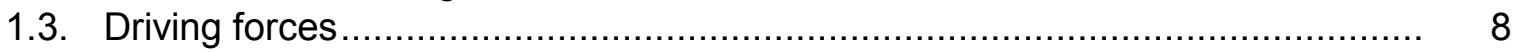

1.4. Diversity of migrant flows ..................................................................... 9

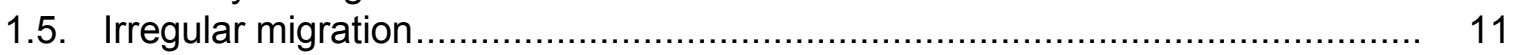

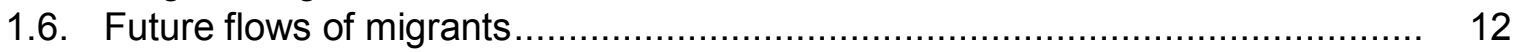

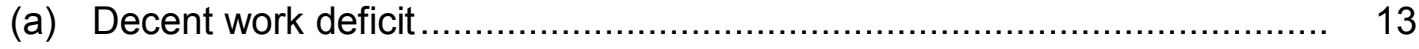

(b) Economic disparities ............................................................... 13

(c) Population density ..................................................................... 14

(d) The demographic deficit ........................................................... 14

1.7. The decline of bilateral migration management....................................... 15

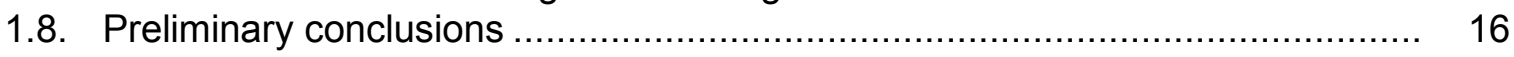

Chapter 2. Migration and its consequences......................................................... 17

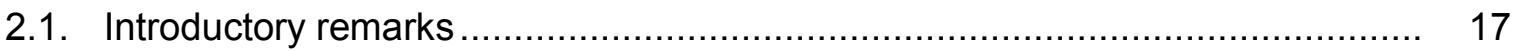

2.2. Impact of migration on countries of origin................................................... 18

(a) Reducing population pressure and unemployment............................ 19

(b) Emigration of skilled persons - The brain drain ................................... 19

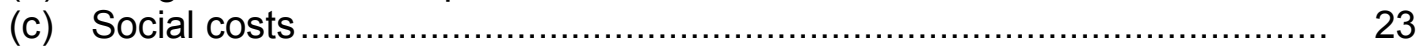

(d) Flows of remittances ................................................................. 23

(e) Transnational communities and home country development ................... 25

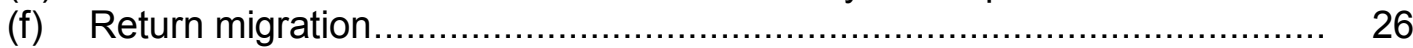

(g) Migration and trade ................................................................... 27

(h) Migration and overall economic performance ....................................... 28

2.3. Impact of immigration on destination countries ...................................... 30

(a) Impact on employment and wages ............................................ 31

(b) Fiscal impact of immigration ..................................................... 34

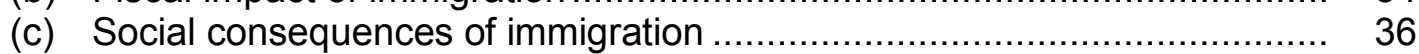

2.4. Preliminary conclusions .................................................................... 40

Chapter 3. Conditions of work and treatment of migrant workers............................ 41

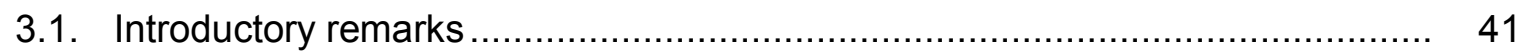

3.2. Scope and criteria of working conditions .................................................... 42

3.3. Factors affecting conditions of work ....................................................... 42

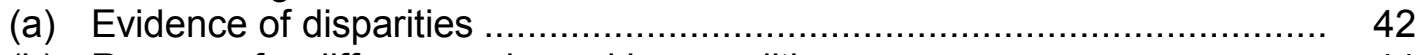

(b) Reasons for differences in working conditions .................................. 44 
3.4. Conditions of work in selected sectors and occupations ......

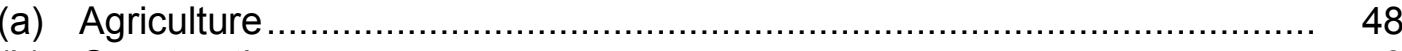

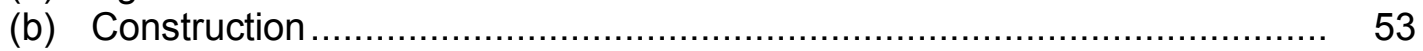

(c) Manufacturing: Sweatshops and migrant workers ................................ 55

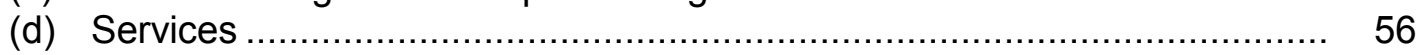

3.5. Most vulnerable groups of workers ….................................................. 58

(a) Women domestic workers ....................................................... 58

(b) Migrant workers in irregular situations .......................................... 60

(c) Trafficked persons..................................................................... 62

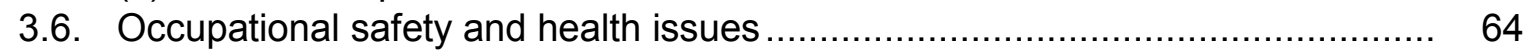

3.7. Integration of migrant workers in host countries ..................................... 67

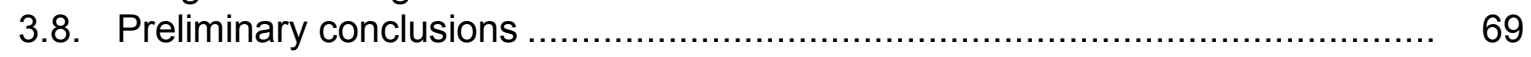

Chapter 4. International regulation of migrant workers and migration ......................... 71

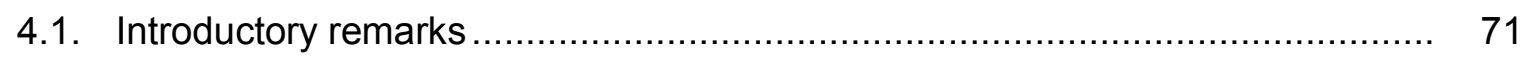

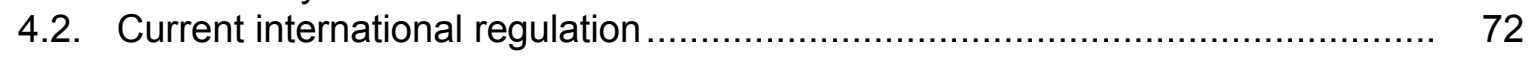

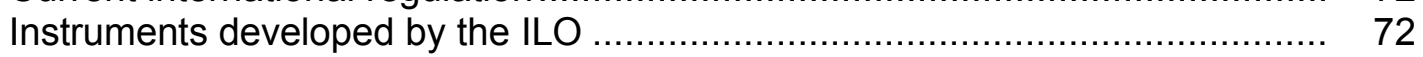

Instruments developed by the United Nations ........................................... 81

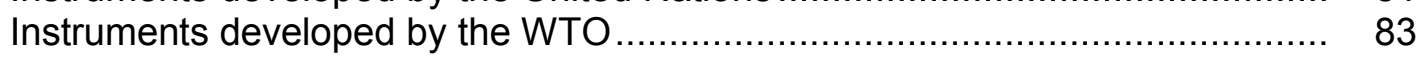

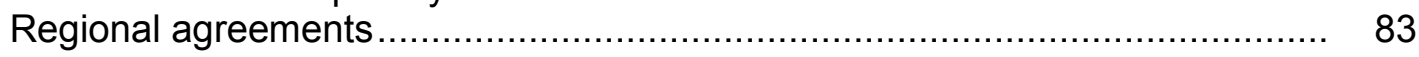

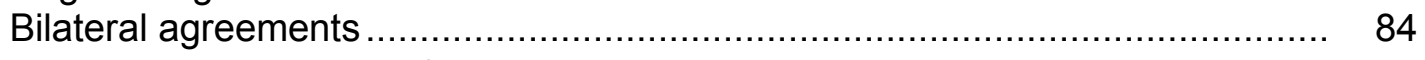

4.3. Relevance and impact of international regulation ................................... 85

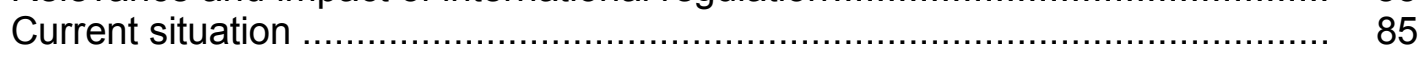

Protecting the rights of specific groups of migrant workers........................ 86

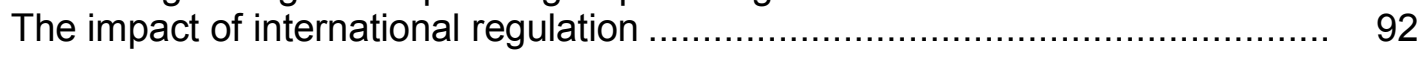

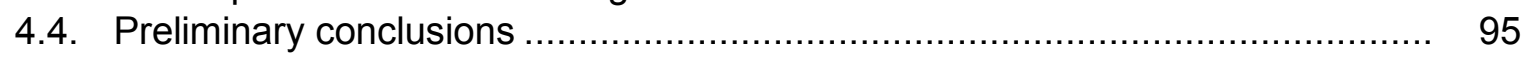

Chapter 5. ILO activities with governments and social partners.............................. 99

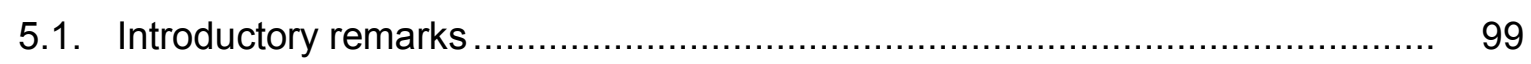

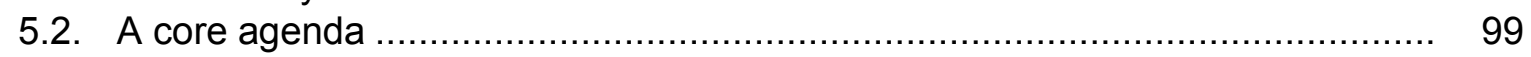

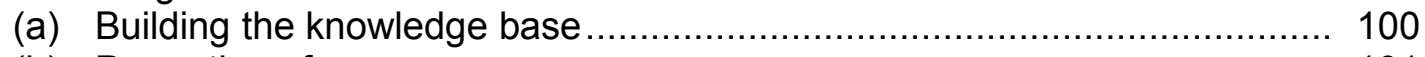

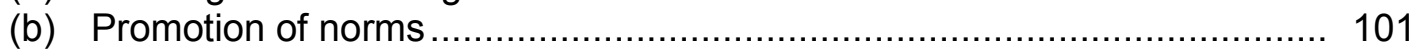

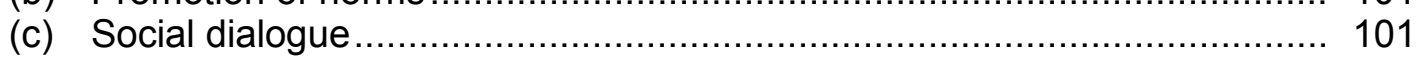

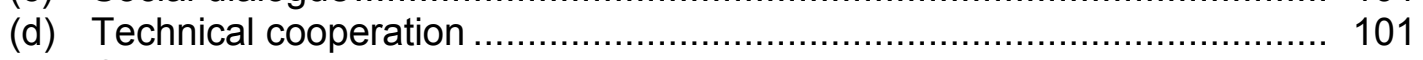

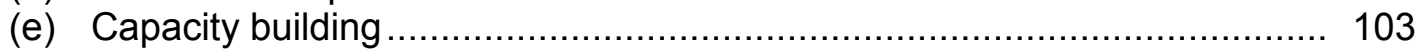

(f) Special action programmes ........................................................ 103

(g) Building international cooperation............................................... 104

5.3. An integrated programme within the ILO .................................................. 105

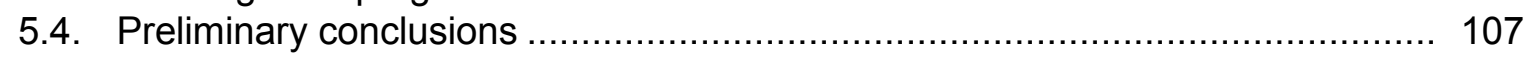

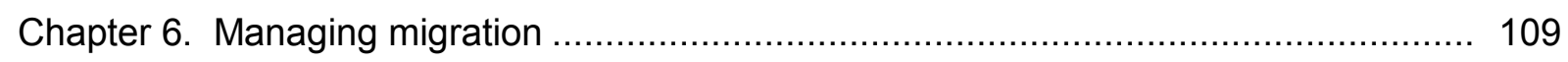

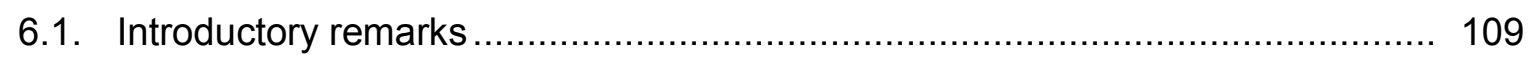

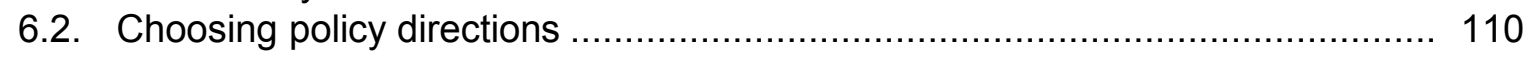

6.3. Towards greater policy coherence ...................................................... 110

Flexibility in administering policy .......................................................... 111

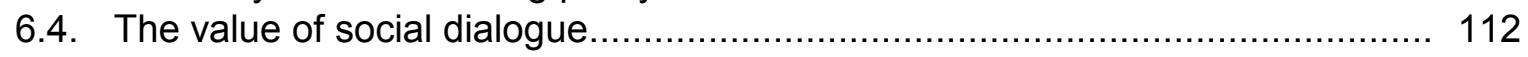

6.5. Aligning foreign labour admissions with economic needs........................... 113

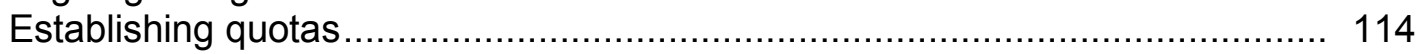

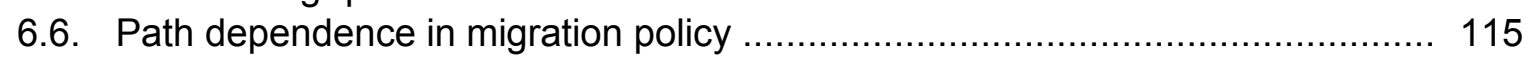

6.7. Making temporary migration schemes work .............................................. 118 
$\begin{aligned} \text { Page } & \text { Page }\end{aligned}$

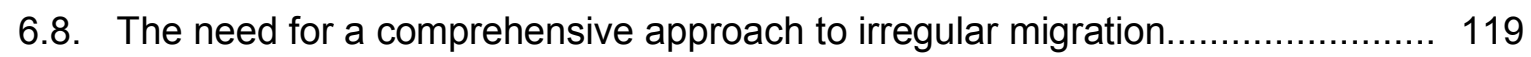

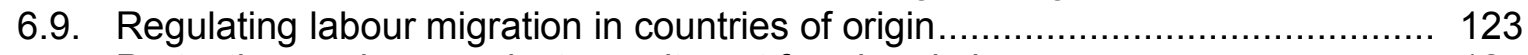

Protecting workers against recruitment fraud and abuses .......................... 125

6.10. Advantages of inter-country cooperation ............................................. 126

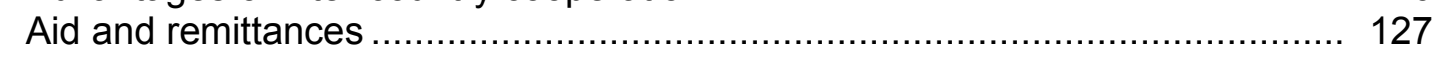

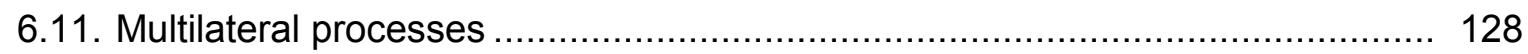

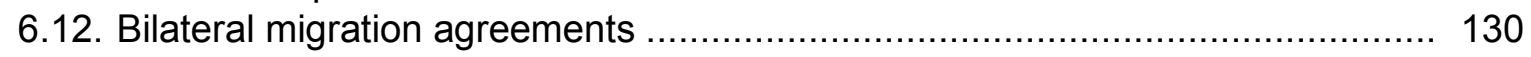

6.13. Regional economic integration and the free movement of labour ................ 131

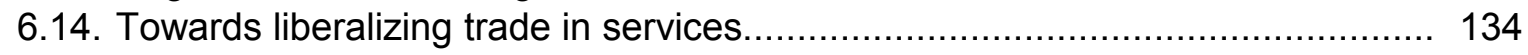

6.15. Preliminary conclusions: A complex policy challenge .............................. 135

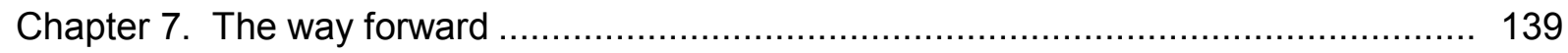

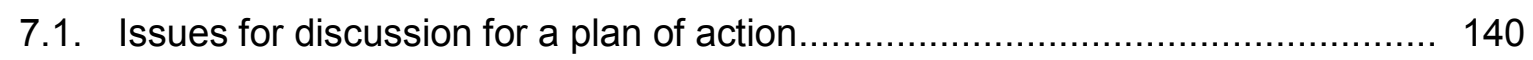

Annexes

I. Summary of replies to the International Labour Migration Survey, $2003 \ldots \ldots \ldots \ldots \ldots \ldots . \ldots \ldots$

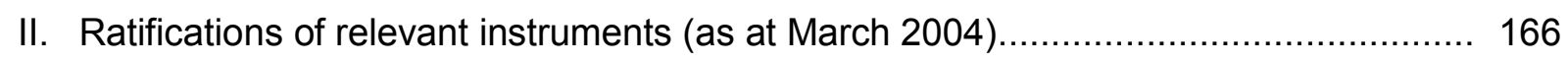

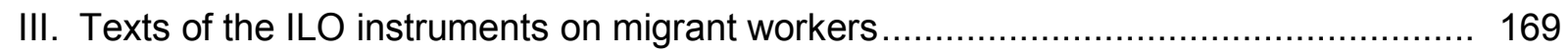




\section{Introduction}

1. The Governing Body of the ILO decided at its 283rd Session in March 2002 to place on the agenda of the 92nd Session (2004) of the International Labour Conference a general discussion on migrant workers based on an "integrated approach". Its agenda is to include:

- labour migration in an era of globalization;

- $\quad$ policies and structures for more orderly migration for employment; and

- improving migrant worker protection through standard setting.

2. This was a most timely decision since the growing cross border movements of labour have emerged as a central issue for the international community. Two recent global reports, one by the World Commission on the Social Dimension of Globalization, and the other by the Global Commission on Human Security, have placed migration issues squarely at the top of their recommendations for a global policy agenda. These reflected the gathering momentum for international action for a new migration order. In 2003, two independent initiatives, The Declaration of the Hague on the Future of Refugee and Migration Policy of the Society for International Development (Netherlands Chapter), and the Swiss Government's Berne Initiative also urged for partnerships in incorporating humanitarian principles in managing migration. At the beginning of $2004 \mathrm{a}$ new Global Commission on Migration was established at the instance of several governments. ${ }^{1}$ In 2006 the High-Level Dialogue of the United Nations General Assembly will be devoted to the issue of migration and development.

3. In practically every region the rising mobility of people in their search for decent work and human security has been commanding the attention of policy-makers and prompting dialogues for multilateral cooperation on how to better manage the flows in the interest of protecting human rights, maximizing migration's contribution to growth and development, and preventing clandestine flows and trafficking. This report has been prepared with these in mind. It links the ILO's concerns with those of other recent initiatives in the field, incorporates new research and data, and synthesizes the lessons that can be drawn from the experience of both origin and host countries in seeking to manage migration to improve the treatment and conditions of migrant workers and members of their families. The analysis offered by the report can hopefully provide a basis for formulating sound recommendations for future action and for the active engagement and participation of the ILO's constituents in their realization.

4. With regard to many issues addressed in the report, much light has been shed by the replies of the ILO's constituents to the International Labour Migration Survey, which

\footnotetext{
1 The Governments of Australia, Brazil, Canada, Egypt, India, Italy, Mexico, Morocco, the Philippines and the United Kingdom comprise an open-ended core group of countries behind the Commission chaired by Switzerland and Sweden.
} 
was undertaken by the Office as part of the preparations for the Conference. Through this Survey the ILO obtained from some 93 member States the latest information on trends in migration and conditions of migrant workers, the state of law and practice, impact of migration, and the experience with structures and policies for regulating migration and employment of migrant workers. While it had not been possible to fully integrate all the findings in the body of the report owing to the late arrival of some replies, the most important findings have been cited in relevant sections. Annex 1 of the report also contains a summary of the replies. A more detailed presentation and analysis of the replies will be published as a separate report.

5. Because of the uneven availability of published information on migration in different regions, it has not always been possible to present a fully global picture of certain aspects of labour migration, much less to discuss them in their full complexity, especially in countries or regions where governance capacities are particularly limited. On the treatment and conditions of employment of migrant workers, for example, the report had to rely heavily on studies and reports available only in a few industrialized countries. The same is true of the discussions on best practices for addressing widely shared problems of irregular migration, discrimination and unequal treatment, and making temporary labour migration schemes work. However, every effort has been made to include in the report those issues that are of common concern to most if not all policy-makers dealing with migration questions. It is hoped that by bringing together in this volume the lessons that may be drawn from experience with policy successes as well as policy failures, the report will have facilitated the work of the General Conference in deciding what the whole Organization can contribute to the establishment of a fair deal for migrant workers in the global economy.

6. In preparing this report the ILO greatly benefited from the advice and information received from many institutions and individuals. Special acknowledgement should be made of the contributions of the other members of the Geneva Migration Group (UNHCR, UNHCHR, UNCTAD, UNODC, and IOM), the UN Population Division, the OECD, WHO, UNESCO and the European Commission. 


\section{Chapter 1}

\section{Labour migration in a globalizing world}

\subsection{Introductory remarks}

7. Migration has emerged as a central issue of our times. Each year millions of men and women leave their homes and cross national borders in search of greater human security for themselves and their families. Most are motivated by the desire for higher wages and better opportunities, but some are forced to leave their homes on account of famine and poverty, natural disasters and environmental degradation, and violent conflict or persecution. Most migration is between neighbouring countries, but greater access to global information and cheaper transport mean that geography now poses less of a barrier to movement. More and more countries are now involved with migration, either as origin, destination, or transit countries, or all of these simultaneously.

8. The world has experienced migration for human betterment, and the factors motivating migration in the past are present today, ${ }^{1}$ and perhaps exert greater force than before as they are accompanied by technological changes that have dramatically reduced the cost of information and communication. Rising economic and demographic differences between nation States make the transfer of people over borders a "natural response" in a globalizing world.

9. While international migration can be a productive experience for most people, many migrant workers suffer poor working and living conditions. Their terms of employment may be better than in their home countries, but they often face conditions far inferior to those available to nationals in host countries. Despite international standards to protect them, their rights as workers are too often undermined, especially if they are unauthorized.

10. The challenge confronting the global community is to manage migration so that it can serve as a force for growth and development, and not lead to clandestine movements and the dangers these pose for established institutions and the respect of labour standards. Various initiatives to develop a global consensus on the rules and principles to govern migration began soon after the demise of bilaterally arranged migration in the mid-1970s, but success has been elusive.

11. Ten years ago, at the 1994 International Conference on Population and Development (ICPD) in Cairo, the need for a new migration regime was discussed; the Programme of Action adopted at that Conference called on origin and destination States to cooperate to protect the rights of migrants, reduce clandestine or irregular migration,

\footnotetext{
${ }^{1}$ National Bureau of Economic Research: What fundamentals drive world migration?, by T.J. Hatton,
} J.G. Williamson, NBER Working Paper 9159 (Cambridge, MA, Sep. 2002), p. 3. 
and combat racism and xenophobia. ${ }^{2}$ This raised hopes for giving specific form to the actions needed at national and multilateral levels to establish a more orderly migration regime in which migration would be mutually beneficial. However, subsequent developments appear to have weakened the ability and the resolve to establish cooperative agreements between origin and destination States to manage migration. Even before 11 September 2001, the growth of refugee flows and various forms of irregular migration, the dilemmas posed by the nexus between asylum and migration, and in some cases the failure of existing legal systems to protect the basic rights of migrants, combined to move migration beyond the "comfort zone" for many policymakers in origin and destination countries. Difficulties with the social integration of some migrants and the complex dilemmas raised by integration in many receiving States suggest that a much greater understanding of the contemporary migration phenomenon is needed to enable the international community to fashion the tools and instruments for better managing migration.

12. Migration issues today occupy the centre stage in national and international public policy debates. Migration was addressed at the World Summit for Social Development in Copenhagen in 1995, at the Fourth World Conference on Women in Beijing (1995), at the Second United Nations Conference on Human Settlements in Istanbul in 1996 and at the World Conference against Racism, Racial Discrimination, Xenophobia and Related Intolerance in Durban in 2001. As a follow-up to the ICPD, a Technical Symposium on Migration and Development was organized in 1998 in the Hague, and later echoed by similar technical meetings at regional levels organized by the United Nations Economic and Social Commissions for Latin America, Africa, and Asia. New mechanisms for temporary migration under the framework of the General Agreement on Trade in Services (GATS) have been launched.

13. At regional levels, inter-country dialogues on refugee and migration issues and the specific problems of trafficking - notably the Barcelona Process and the Puebla Process - serve as vehicles for consultation and for achieving greater cooperation among States in the area of migration governance. In the European Union several conferences, under the auspices of the Presidency, have also been organized to review, among other things, the experience with harmonization of policies on migration and social integration and the various approaches to de-linking refugee and migration outcomes.

14. Other initiatives aimed at developing ideas for an international framework for migration governance include the "Berne Initiative", sponsored by the Federal Office for Refugees of Switzerland, and the 2003 "Declaration of The Hague on the Future of Refugee and Migration Policy" - the contribution of the Netherlands Chapter of the International Society for Development. Two international commissions, the Commission on Human Security and the World Commission on the Social Dimension of Globalization, have argued for better management of global migration. At the initiative of Sweden and Switzerland, a Global Commission on Migration was launched in December 2003 with a mandate for placing international migration on the global agenda and analysing gaps in current approaches. On a more informal basis there are regular consultations between international agencies concerned with migration such as the ILO, IOM, UNCTAD, UNHCHR, UNHCR and UNODC and in what has been called the Geneva Migration Group.

\footnotetext{
${ }^{2}$ United Nations: Report of the International Conference on Population and Development, A/CONF.171/13/Rev.1, New York, 1995.
} 
15. In response to the low and declining rate of ratification of the ILO's existing standards on this subject, the Committee of Experts on the Application of Conventions and Recommendations was requested by the Governing Body at its 267th Session (November 1996) to undertake a General Survey on the state of law and practice with respect to migrant workers. ${ }^{3}$ The Committee of Experts clearly saw the need for a general discussion on the subject at a future session of the International Labour Conference, with a view to reviewing and possibly revising the instruments. This was endorsed by the members of the Governing Body, which also saw the need for discussing the subject on this basis of an "integrated approach".

16. For these reasons the general discussion on migrant workers based on an integrated approach at the 92nd Session of the International Labour Conference (2004) acquires special significance. Within the larger context of identifying the principles for establishing a more sustainable migration order, this discussion aims to identify the areas of consensus on ways in which migration for employment might be managed to contribute to a better world for all.

\subsection{Growth of labour migration}

17. The migration of workers from developing countries to the industrialized countries has been on the rise for the last few decades; however, in 1998 migrants still represented no more than 4.2 per cent of the industrialized countries' total workforce. The United States absorbed the bulk of the increase (more than 81 per cent of the new migrants from developing countries), while Canada and Australia accounted for another 11 per cent. In the European Union, migrants were also heavily concentrated in four countries - France, Germany, Italy and the United Kingdom. Throughout the 1990s the number of those coming from developing countries grew significantly faster than those originating from other OECD countries, so that by 1998 they had become the bigger group, representing some 57.8 per cent of all migrant workers in the organization's member countries.

18. Close to half of all reported migrants move from one developing country to another. Indeed, considerable migration for employment takes place between and among countries where differentials in wages are not very large. For example there have been large movements of workers from Haiti to the Dominican Republic, from Burkina Faso to Côte d'Ivoire, from Egypt to Jordan, from Indonesia to Malaysia, or to Argentina from neighbouring countries. Some 2 million Asian workers leave their countries every year to work in other countries within and outside the region under short-term employment contracts. ${ }^{4}$

\footnotetext{
${ }^{3}$ ILO: Migrant workers, Report III (Part IB), International Labour Conference, 87th Session, Geneva, 1999.

${ }^{4}$ See M. Abella: "Driving forces of labour migration in Asia”, in World Migration 2003 (IOM, Geneva, 2003).
} 


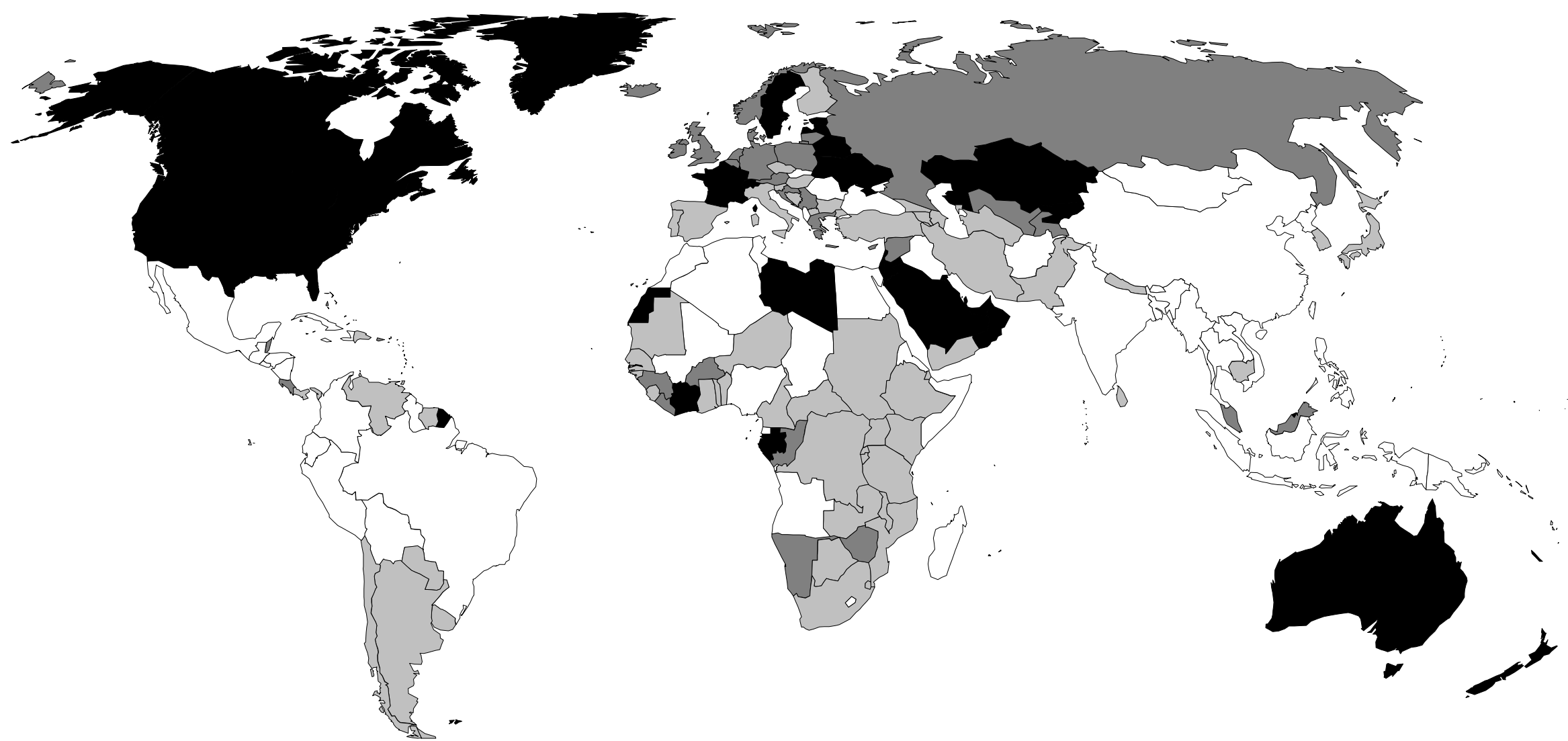

More than $10 \%$ 
19. The full global magnitude of these flows is hard to ascertain because not all countries monitor, and fewer still report on, labour migration flows, but the phenomenon is undoubtedly significant and growing. ${ }^{5}$ It is estimated that there are today over 86 million economically active migrants the world over, of whom some 32 million are in the developing regions. Even this figure is likely to be an underestimate since there are considerable difficulties with migrant population data in almost every country - and particularly in some regions.

\section{Table 1.1. ILO estimates of migrant workers by region, 2000 (provisional)}

\begin{tabular}{|c|c|c|c|c|c|c|}
\hline \multirow[t]{3}{*}{ Region* } & \multirow{2}{*}{\multicolumn{2}{|c|}{$\frac{\text { Migrants }^{* *}}{\text { Including refugees }}$}} & \multicolumn{4}{|c|}{ Migrant workers } \\
\hline & & & \multicolumn{2}{|c|}{ Excluding refugees } & \multicolumn{2}{|c|}{ Including refugees } \\
\hline & Millions & $\%$ dist. & Millions & $\%$ dist. & Millions & $\%$ dist. \\
\hline Africa & 16.3 & 9 & 5.4 & 7 & 7.1 & 8 \\
\hline Asia & 49.9 & 29 & 22.1 & 27 & 25.0 & 29 \\
\hline Europe & 56.1 & 32 & 27.5 & 34 & 28.2 & 33 \\
\hline $\begin{array}{l}\text { Latin America and the } \\
\text { Caribbean }\end{array}$ & 5.9 & 3 & 2.5 & 3 & 2.5 & 3 \\
\hline North America & 40.8 & 23 & 20.5 & 25 & 20.5 & 24 \\
\hline Oceania & 5.8 & 3 & 2.9 & 4 & 2.9 & 3 \\
\hline Total & 174.9 & 100 & 80.9 & 100 & 86.3 & 100 \\
\hline \multicolumn{7}{|c|}{$\begin{array}{l}{ }^{*} \text { Regions as defined by the UN Statistics Division. }{ }^{* *} \text { United Nations Population Division estimates of stock of migrants. UNDP } \\
\text { 2002, International Migration 2002, New York, United Nations. }\end{array}$} \\
\hline \multicolumn{7}{|c|}{$\begin{array}{l}\text { Source: ILO provisional estimates based on UN estimates of migrant stocks (UNDP, op. cit.) and country-specific economic activity } \\
\text { rates (ILO, Bureau of Statistics. 1996: Economically Active Population, STAT Working Papers 1996-1, 2, 3, } 4 \text { and 5, Geneva, ILO), } \\
\text { and available country data on economically active foreigners and/or foreign-born persons. }\end{array}$} \\
\hline
\end{tabular}

20. Today's migrant workforce includes workers with a variety of skills. At the upper end are the professionals and managers who move within the internal labour markets of transnational corporations in the course of expanding trade or direct foreign investments. These so-called "intra-company transferees" have become a ubiquitous presence in the more dynamic regions of the world, where they are the purveyors of new production techniques and managerial know-how. Three out of every four transferees move from one rich country to another, especially across the Atlantic, while the rest largely move to and from one of the more successful newly industrializing countries in East Asia and South America. Outside of movements within these internal markets, there are larger movements of professionals and highly skilled labour in multiple occupations such as ICT, medicine, teaching, sea and air navigation, journalism and communications, and entertainment. Some of these movements of individuals may fall within the so-called "Mode 4" negotiations on trade in services.

\footnotetext{
${ }^{5}$ Most countries have different systems for compiling statistics to suit their particular needs. This makes comparisons across countries difficult. When estimating migrant numbers, some countries gather statistics only on foreign citizens and thus do not count those immigrants who have naturalized; others gather statistics on the "foreign born". There are also differences in administrative capacity. Countries with better statistical systems would have better coverage of migration statistics. In many parts of the world, migrants frequently cross borders without being included in any migration records.
} 
21. Nonetheless, contemporary migration flows are still dominated by workers moving to fill unskilled jobs in those segments of the labour market vacated by native workers who move on to better jobs. However the significance of migrant labour in these segments is not uniform across regions, especially in the OECD countries where recent flows are increasingly becoming more skilled. Labour and immigration policies influence the absorption of migrant workers in different economic sectors, so that migrant farm workers are more important in the United States than in Western Europe.

22. By 2000, around 175 million people were residing outside their country of birth or citizenship -3 per cent of the world's population. ${ }^{6}$ Over the last decade their numbers increased by about 6 million a year, representing a rate of growth faster than the growth of the world's population. However, world trade has been growing at more than twice the rate of growth of world gross domestic product since 1990, while net private capital flows to developing countries have grown by more than eight times the level of such flows in the mid-1980s. Nevertheless, if international migrants were considered together they would account for the world's fifth most populous "country".

23. Many countries are both sources and destinations for migrants. Canada, for example, is a traditional destination for migrants but also sends significant numbers of people, particularly the highly skilled, to the United States. Similar phenomena have emerged in Asia. Thus, Thailand receives many unskilled immigrants from Myanmar, Cambodia, and the Lao People's Democratic Republic, but also sends its own people to other countries including Israel, Japan, and Taiwan (China).

\subsection{Driving forces}

24. The forces driving migration are many and complex, and global explanations may not apply to individuals. Poverty, wars, famine and repression are certainly among the major causes of migration, but there are other factors as well. Reasons individuals cite for crossing national borders include population pressures on scarce natural resources, wage or income inequality between the poor and rich countries, growing urbanization, reduction in the cost of transport and communications and increasing interactions among societies, civil conflict and absence of human rights, and establishment of migration networks by earlier migrants. It is generally recognized, however, that both increasing differences between countries and the lack of gainful employment, decent work, human security and individual freedoms help explain much contemporary international migration. ${ }^{7}$

25. Civil conflicts in many parts of the world have dislocated many from their homes and forced them to seek temporary protection, often in neighbouring countries. During the last decade the number of refugees globally peaked at an estimated 18.2 million but has since declined to about 12 million. The growth in the number of asylum claimants nevertheless has raised anxieties among the signatories to the 1951 Geneva Convention and the 1967 Protocol relating to the Status of Refugees about their capacity to host more refugees, since many refugees and asylees work in host countries. Other factors in particular political instability and population displacement related to the consequences of global warming - promise more migration pressures. While the focus of this report is

\footnotetext{
${ }^{6}$ United Nations, International Migration 2002, op. cit.

${ }^{7}$ P. Martin and J. Widgren: International migration: Facing the challenge (Washington, DC Population Reference Bureau, Population Bulletin), 2002, Vol. 57, No. 1.
} 
not on refugees, those refugees that actually work in destination countries are considered migrant workers (though often in the capacity of irregular workers). The world's population of 6.3 billion is growing by about 84 million every year - of which 97 per cent are in the developing countries. Some 100 million new entrants join the world's labour market every year, most of them in developing countries, aggravating the already serious problem of unemployment estimated at no less than 1 billion unemployed or underemployed.

26. For a variety of demographic, political and other reasons, the economic gains from the progressive integration of the global economy have yet to materialize for many of the world's poor countries. Despite the gains made by the more populous developing countries, such as China and India, in raising incomes over the past two decades, the gap in per capita incomes between the rich and the poor countries has remained large, and a recent ILO study shows that inter-country inequality as measured in GDP per capita has increased. ${ }^{8}$ In the words of the ILO Director-General, Juan Somavia, “... If you look at the global economy from the perspective of people, its biggest structural failure is the inability to create enough jobs where people live". 9

27. Globalization may yet narrow the income gaps between nation States. History shows that the movement of goods rather than the movement of people has been the key factor in the success of some developing countries catching up with the more advanced ones. The East Asian economic miracle was based on a comparative advantage in lowcost labour to manufacture goods that were exported; it has since spread to China, where per capita incomes have doubled in less than a decade. However, the general replicability of this model has been in dispute in other developing countries with weaker capacities to produce manufactures or where other conditions for successful management of the development process are not present.

28. Some low-income countries dependent on a few agricultural exports such as cotton and maize have suffered from increased competition with subsidized exports of the same commodities by the more developed countries. A recent general equilibrium analysis of trade policies for low-income countries like those in sub-Saharan Africa indicates that trade liberalization by a low-income country only generated increased emigration because liberalization led to a sharp fall in the real exchange rate. ${ }^{10}$

\subsection{Diversity of migrant flows}

29. There are many ways of categorizing migrant workers based on motivations, skills, age, occupation or distance from origin; the categories most commonly used are based on anticipated duration of stay, reflecting the fact that control over entry and stay is a core aspect of national sovereignty. Most migrant workers enter other countries through one of three channels:

- Permanent migration, primarily for highly skilled migrants, family unification and refugee resettlement.

\footnotetext{
8 ILO: Trade and international labour mobility, by A.K. Ghose, ILO Employment Papers, 2002/33 (Geneva, 2002).

9 Statement to the International Co-operative Alliance General Assembly (Oslo, 3 Sep. 2003).

10 See R. Faini, J.M. Grether and J. de Melo: "Globalization and migratory pressures from developing countries: A simulation analysis", in R. Faini, J. de Melo and K.F. Zimmermann (eds.): Migration: The controversies and the evidence (London, Cambridge University Press, 1999).
} 
- $\quad$ Temporary migration for all types of employment. This door allows the entry of migrants, commonly known as guest workers, to fill vacant jobs that persist, such as nursing positions.

- $\quad$ Temporary migration for time-bound employment. Allows the entry of migrants to fill seasonal jobs - jobs that will end with the completion of a project, e.g. a construction - and service providers, trainees and students.

30. Although migrants from developing countries work in almost every type of job, they tend to concentrate at the bottom and the top of the employment ladder. The majority of migrants are at the bottom of the ladder and often do the dirty, dangerous and difficult - "3-D" - jobs that, once they become "migrant jobs", tend to remain migrant jobs.

31. At the other end of the scale are millions of professional workers who travel to other countries in search of higher wages or greater opportunities The majority of migrant professionals - three out of four - move from one rich country to another, especially across the Atlantic, while many of the rest move between the more successful newly industrializing countries in East Asia, among the countries of Central and Eastern Europe, as well as between countries in South America. A significant number also migrate to poorer countries, often accompanying foreign investment, thus helping to accelerate economic development.

32. Most countries welcome the arrival of professionals from other countries. Australia and Canada, for example, have points systems that make it easier for professionals from developing countries to enter as immigrants. The United States also makes it relatively easy for professionals to immigrate or to enter with temporary visas if a United States employer requests them. During the 1990s, many developed countries recruited foreign health professionals; consequently nearly one-third of doctors and 13 per cent of nurses in the United Kingdom are foreign born, and half the extra staff employed by the National Health Service over the past decade qualified abroad. ${ }^{11}$ From 1995 to 2000 in the OECD countries, the foreign labour force grew by 3-4 per cent per year; however, the highly educated migrant workforce grew much faster - on average 35 per cent annually in the United Kingdom over the past five years, and 14 per cent a year in the United States.

33. Women account for an increasing proportion of international migrants - from 47 per cent in 1960 to 49 per cent in 2000 - reflecting the rising importance of family unification, especially in more developed countries. However, more women are travelling on their own as their family's primary income earner, a consequence of a number of social and economic transformations. In the more developed destination countries, populations are ageing, which increases the demand for female health workers. Another contributing factor is rising prosperity: in some of the faster growing developing countries, such as Malaysia and Chile, as families become wealthier they employ foreign domestic help.

34. At the same time there has been a general feminization of the workforce, particularly in labour-intensive manufacturing industries and in many services. Thus, garments manufacturers in the industrialized countries may employ women migrants directly to take the place of local workers who move on to better jobs.

${ }^{11}$ D. Walker: "Statistics show immigration beneficial to economy", in The Guardian (London), 29 Jan. 2001. 
35. This feminization of migrant workers is most evident in Asia, where hundreds of thousands of women emigrate each year in both unskilled and skilled professions - the majority in domestic service and entertainment and, to a lesser extent, in nursing and teaching. The main source countries are Indonesia, Philippines, Sri Lanka and Thailand, while the main destinations are Hong Kong (China), Malaysia, Singapore and the Middle East. In the case of the Philippines, women accounted for about 61 per cent of all new hires of overseas land-based contract workers in 1998; as for Indonesia, they accounted for around 78 per cent of officially reported emigrants in the 1996-97 period. In Sri Lanka, in 2000, of the estimated stock of 858,000 emigrants, 590,420 were women - the majority of whom went to work as housemaids and 90 per cent of whom went to the Middle East. ${ }^{12}$

\subsection{Irregular migration}

36. People who enter or work in countries without legal authorization have been labelled illegal, clandestine, undocumented or irregular. "Illegal migrants" were once a residual category, but illegal has a normative connotation and conveys the idea of criminality. Thus, the 1994 International Conference on Population and Development recommended the term "undocumented"; but this is incomplete, since it does not cover migrants who enter the host country legally with tourist documents but later violate their conditions of entry by taking a job. Furthermore, migrants moved by traffickers over borders may have false documents; this prompted an International Symposium on Migration in Bangkok in April 1999 to recommend the term "irregular". Irregularities in migration can arise at various points - departure, transit, entry and return - and they may be committed against the migrant or by the migrant.

37. Information obtained from regularization programmes and other sources suggests that 10 to 15 per cent of migrants are irregular. ${ }^{13}$ In the United States, there were an estimated 7 to 8 million irregular migrants in 2000. In Europe, at that time, irregular foreigners who had been regularized accounted for 4 per cent of total migrants in France, 14 per cent in Portugal and Spain, and 25 per cent in Greece and Italy. ${ }^{14}$ That same year, there were 22 million foreign nationals resident in Western Europe. If the number of irregular migrants were equivalent to, say, 15 per cent of the foreign population, the total number in irregular status would be 3.3 million - which is in the range commonly quoted. An estimate of flows has also been made by Europol, which believes that there is an annual inflow to the European Union (EU) of around half a million undocumented workers. ${ }^{15}$ In the Russian Federation the Interior Ministry in September 2003 estimated that there were 5 million foreigners whose legal status was unclear, of whom 1.5 million were "clearly unauthorized". ${ }^{16}$ Several countries in Central Europe like Poland, Hungary and the Czech Republic are now faced with problems of dealing with thousands of

\footnotetext{
12 D. Malsiri and R. Jayasundere: Sri Lanka: Good practices to prevent women migration workers from going into exploitative forms of labour (Geneva, ILO, Gender Promotion Programme Working Paper No. 9, 2000).

13 NBER: T.J. Hatton; J.G. Williamson, op. cit.

14 J. Salt: Current trends in international migration in Europe (Council of Europe, CDMG (2002), 26 Dec. 2002).

15 European Commission: Communication from the Commission to the Council and European Parliament on a Community Immigration Policy (Brussels, COM 757, 2000).

${ }^{16}$ Migration News (University of California, Davis), Oct. 2003, Vol. 10(3).
} 
migrants from other regions who are seeking eventual entry to one of the Western European countries.

38. Irregular migration is not confined to the developed countries. In Argentina, for example, it was estimated in 2004 that there were 800,000 irregular migrants, mainly from the bordering countries. Many parts of Asia, Africa and Latin America have long and porous borders that people commonly cross without going through immigration posts, as with the Democratic Republic of the Congo in Africa and the border between Myanmar and Thailand. Indeed in many of these regions, most of the migratory flows might better be considered as informal, since the authorities are frequently aware of them but tolerate them - either because they do not have the capacity to police borders adequately or because they recognize that immigrants serve a useful purpose for certain interest groups and communities.

39. Asia is thought to have several million irregular migrants. The largest numbers are likely to be Nepalese and Bangladeshis in India, Afghans in Pakistan and the Islamic Republic of Iran, Indonesians and Filipinos in Malaysia, and Burmese in Thailand. In 2001 there were 255,000 overstayers in the Republic of Korea and 224,000 in Japan.

40. The extent of the flows of irregular workers is a strong indication that the demand for regular migrant workers is not being matched by the supply, with migrants serving as the buffers between political demands and economic realities. If they have to travel long distances, irregular migrants often pay for the services of smugglers, who might conceal them in trucks or ships or supply false documents, or bribe immigration officials. ${ }^{17}$ Smugglers can charge US\$200-300 to get migrants across a land border, or about US\$30,000 to transport them from East Asia to North America or to Europe.

41. According to the Protocol against the Smuggling of Migrants by Land, Sea and Air, supplementing the United Nations Convention against Transnational Organized Crime (2000), the "smuggling of migrants" is the procurement of the illegal entry of a person into a State of which the person is not a national or a permanent resident, in order to obtain, directly or indirectly, a financial or other material benefit. Smugglers provide services to willing customers - acting as extra-legal travel agents. Trafficking, on the other hand, involves the use of violence, coercion or deception to exploit workers essentially treating people as commodities, and does not require crossing an international border, although the same people or gangs are often involved in both smuggling and trafficking. Trafficked migrants are the victims, and should not be liable to criminal prosecution.

\subsection{Future flows of migrants}

42. The flow of migrants over borders may be attributed to various differences between countries - demographic or economic - and to a lack of employment, decent work and human security. Differences are growing and conditions often worsening; this promises more migration in the future.

\footnotetext{
${ }^{17}$ P. Taran and G. Moreno-Fontes Chammartin: Getting at the roots: Stopping exploitation of migrant workers by organized crime (Geneva, ILO, International Migration Programme, Paper 1E, 2002).
} 


\section{(a) Decent work deficit}

43. In a number of countries, freer trade has replaced or undercut domestic industrial and agricultural industries displacing workers, while Structural Adjustment Programmes (SAPs) have restricted government spending to cushion unemployment. Job creation in some countries under SAPs has lagged behind the increased number of unemployed, and a net result of these job losses due to trade and structural change has been large numbers of people without opportunities for decent work in their homelands.

\section{(b) Economic disparities}

44. Economic differences are also widening. Globally, per capita GDP in 2003 was around US\$5,000 a year, but at the country level per capita GDP varied from US\$100 in Ethiopia to US\$38,000 in Switzerland. Moreover the gaps appear to be widening (table 1.2). In 1975, incomes in the high-income countries were 41 times greater than those in low-income countries, and eight times greater than those in middle-income countries. Meanwhile, very few low- and middle-income countries have been joining the high-income ranks. ${ }^{18}$

Table 1.2. Global incomes, population and migration, 1975-2000

\begin{tabular}{|c|c|c|c|c|c|c|c|c|c|}
\hline \multirow[t]{2}{*}{ Year } & \multirow{2}{*}{$\begin{array}{l}\text { Migrants } \\
\text { Millions }\end{array}$} & \multirow{2}{*}{$\begin{array}{l}\text { World } \\
\text { population } \\
\\
\text { Billions }\end{array}$} & \multirow{2}{*}{$\begin{array}{l}\text { Migrants as } \\
\text { a proportion } \\
\text { of world } \\
\text { population }\end{array}$} & \multirow{2}{*}{$\begin{array}{l}\text { Average } \\
\text { annual } \\
\text { increase in } \\
\text { number of } \\
\text { migrants } \\
\text { Millions }\end{array}$} & \multicolumn{3}{|c|}{ Income group by GDP (US\$) } & \multicolumn{2}{|l|}{ Ratios } \\
\hline & & & & & Low & Middle & High & $\begin{array}{l}\text { High- } \\
\text { low }\end{array}$ & $\begin{array}{l}\text { High- } \\
\text { middle }\end{array}$ \\
\hline 1975 & 85 & 4.1 & 2.1 & 1 & 150 & 750 & 6200 & 41 & 8 \\
\hline 1985 & 105 & 4.8 & 2.2 & 2 & 270 & 1290 & 11810 & 44 & 9 \\
\hline 1990 & 154 & 5.3 & 2.9 & 10 & 350 & 2220 & 19590 & 56 & 9 \\
\hline 1995 & 164 & 5.7 & 2.9 & 2 & 430 & 2390 & 24930 & 58 & 10 \\
\hline 2000 & 175 & 6.1 & 2.9 & 2 & 420 & 1970 & 27510 & 66 & 14 \\
\hline \multicolumn{10}{|c|}{$\begin{array}{l}\text { Notes: Migrants are defined as persons outside their country of birth or citizenship for } 12 \text { months or more. The estimate for } 1990 \text { was raised from } \\
120 \text { million to } 154 \text { million, largely to reflect the break-up of the USSR, thought many of these additional migrants did not move; they were, for } \\
\text { example, Russians considered foreigners in Estonia. }\end{array}$} \\
\hline \multicolumn{10}{|c|}{ Sources: United Nations Population Division and World Bank Development Indicators; 1975 income data are those for 1976.} \\
\hline
\end{tabular}

45. Another economic factor that could encourage migration from developing countries is the plight of farmers. In 2000 around 43 per cent of the world's workers were employed in agriculture, and in the poorer countries they are usually worse off than urban dwellers - a result in part of the high cost of farm inputs and the low prices they receive for their crops. This is the reverse of the situation in the more developed countries where farmers are often heavily subsidized. These gaps encourage rural-urban migration; indeed, between 1980 and 1999 the urban share of the population rose from

\footnotetext{
${ }^{18}$ P. Martin and M.I. Abella: Globalization and guest workers: Migration for employment in the 21st century (forthcoming).
} 
32 to 41 per cent in low- and middle-income countries. ${ }^{19}$ Many industrial countries had a "great migration" off the land in the 1950s and 1960s, and similar movements are evident today in many major source countries, including China, Mexico and Turkey.

46. This trend has several implications for international labour migration. First, exfarmers everywhere are more likely to accept dirty, dangerous, and difficult ("3-D") jobs in urban areas. This is happening in China, where internal rural-urban migrants fill many of the "3-D" jobs in the coastal cities. Second, many ex-farmers, who make physical as well as cultural transitions when they arrive in cities, may find it just as easy to emigrate overseas if there is a recruitment or migration infrastructure to help them. Once an exfarmer moves to a city, it is usually far easier to obtain visas and documents for legal migration, or to make arrangements for irregular migration. Mexicans leaving southern Mexico, or Turks leaving eastern Turkey, when faced with the prospect of integrating into a large city, may find it just as easy to adapt to Los Angeles or Berlin.

\section{(c) Population density}

47. The population of the more developed regions of the world is rising at an annual rate of 0.25 per cent, while that of the less developed regions is increasing nearly six times as fast, at 1.5 per cent annually; these differences will largely persist until around 2050. ${ }^{20}$ Population density is already higher in developing than in developed countries 51 persons per square kilometre in low- and middle-income countries, compared with 29 in the high-income countries. In broad terms it might therefore be expected that just as the nineteenth century was marked by migration from densely populated Europe to more sparsely populated America and Oceania, so migration in the first half of this century might similarly respond to differences in population density.

\section{(d) The demographic deficit}

48. There is a contrast between the ageing populations of the more developed countries and the more youthful populations of developing countries. Although populations are ageing to some extent almost everywhere, the process has gone much further in Europe and Japan, with fertility so low that deaths exceed births. On present trends, between 2000 and 2050 the population of Italy, for example, is projected to drop by 22 per cent and by 52 per cent in Estonia and 44 per cent in Latvia. ${ }^{21}$ Low fertility and rising life expectancy mean that, for Europe as a whole, the proportion of the population older than 65 years of age will rise from 15 to 28 per cent between 2000 and 2050, and in Japan from 17 to 36 per cent.

49. In its report, the United Nations Population Division concludes that if immigration were the only means of maintaining current labour forces, it would need to be much higher. The big four EU countries - France, Germany, Italy and the United Kingdom account for two-thirds of the EU population and 88 per cent of its immigrants. If their 1995 populations were to remain constant, given current fertility rates, immigration levels would have to triple, from 237,000 to 677,000 a year. However, if the objective were not just to maintain the 1995 population but also the 1995 workforce, and to maintain the dependence ratio, the big four alone would have to accept 1.1 million

\footnotetext{
19 ibid.

${ }^{20}$ United Nations Population Division: World Population Prospects: The 2002 Revision (New York, United Nations, 2003).

21 ibid., Vol. II: Sex and age distribution of the world population (medium variants).
} 
immigrants a year. Immigration on this scale is unlikely, but there is no doubt that immigration at some level will make an important contribution. Chapter 2 discusses this issue further.

\subsection{The decline of bilateral migration management}

50. Most migration reflects individual or family initiatives, as people leave home to take advantage of opportunities overseas. This is in marked contrast to earlier eras when a significant proportion of migration took place under the aegis of bilateral agreements between governments.

51. One of the earliest bilateral recruitment programmes was the Bracero programme, which from 1942 to 1966 admitted around 5 million workers from Mexico to the United States. It was eventually halted because unions, churches, Mexican-American leaders and others concluded that having Bracero workers in the fields slowed the upward mobility of Mexican-Americans.

52. During the 1950s and 1960s a number of European countries also established programmes that actively recruited workers overseas and ratified the Migration for Employment Convention (Revised), 1949 (No. 97) which aimed to regulate such flows. In the 1950s, France, for example, encouraged the long-term settlement of workers arriving first from southern Europe then from North Africa. In the 1960s, the West German Government followed France's lead and set up recruitment offices in the major source countries - Italy, Greece, Turkey and Yugoslavia - initially looking for seasonal workers and then Gastarbeiter to work on short-term contracts. There were similar schemes in other countries such as Belgium and the Netherlands.

53. What distinguished these movements was the role played by States in organizing and closely supervising recruitment, employment, and return. Employers seeking foreign workers sent their request to local public employment offices, which then relayed it to public employment authorities abroad, where workers were recruited, tested, and selected. Between 1960 and 1966 the Gastarbeiter programme brought some 3.6 million foreign workers to West Germany, and 3 million returned home as expected. ${ }^{22}$

54. By the mid-1970s this bilateral system collapsed. The global recession that followed the oil shock of 1973 reduced the demand for immigrant workers, and governments applied more restrictions to guest workers to encourage their departure, although only 10 per cent left. ${ }^{23}$ Large-scale organized labour migration to Europe through bilateral agreements came to an end in the late 1970s, and the labour migration that occurred as growth resumed involved migrants entering via family reunification channels, or as tourists, asylum-seekers or students - or clandestinely with the help of smugglers and traffickers.

55. Most labour migration policies today are unilateral, in the sense that destination countries normally announce programmes to admit migrants without seeking bilateral agreements with source countries. There is growing recognition that cooperative

\footnotetext{
${ }^{22}$ H. Werner: From guests to permanent visitors? A review of the German experience (Geneva, ILO, International Migration Papers No. 42, International Migration Programme, 2001).

23 J.-P. Garson and A. Loizillon: Changes and challenges: Europe and migration from 1950 to present, Paper for the European Commission/OECD Conference on the Economic and Social Aspects of Migration, Brussels, 21-22 Jan. 2003.
} 
migration management can better achieve goals for both sending and receiving countries, and there has been an upsurge in bilateral memoranda of understanding (MOUs) and agreements; however, most programmes to admit foreign workers are unilateral. For the source countries, unilateral action means trying to manage the process of emigration. Some of the major Asian source countries, including Indonesia, the Philippines, and Sri Lanka, closely regulate and supervise the recruitment of their nationals for employment in foreign countries.

56. Multilateral action has been most successful in establishing international norms. The ILO pioneered two Conventions: the Migration for Employment Convention (Revised), 1949 (No. 97), and the Migrant Workers (Supplementary Provisions) Convention, 1975 (No. 143); in 1990, the United Nations General Assembly adopted a new Convention on the Protection of the Rights of All Migrant Workers and Members of their Families, which entered into force in 2003.

\subsection{Preliminary conclusions}

57. Economic, political and demographic factors suggest that we are in an age of growing migration pressures. Every year many millions of young men and women enter the labour force in developing countries where jobs are not created fast enough to absorb them; meanwhile populations are ageing in the more developed regions, where scarcities of labour are emerging in many sectors. Other developments that add to migration pressure include rising differences that motivate or cause people to move over borders, and new technologies that allow more people to acquire the information they need to access the global labour market.

58. Migration has historically been beneficial to most migrants as well as countries of destination and origin. However, efforts to build an acceptable multilateral framework for regulating movements to ensure that labour migration yields mutual benefits have so far not seen much evidence of success. The number of migrant workers in an irregular situation is rising rapidly, fuelled to some extent by the growing commercialization of migration processes, including smuggling and trafficking - but also by the growth of informal forms of employment in destination countries. Unless the international community acts, this situation is likely to worsen, with worrisome implications for the protection of migrant workers' rights until such time as migration pressures are reduced by faster economic development. 


\section{Chapter 2}

\section{Migration and its consequences}

\subsection{Introductory remarks}

59. Since human beings first emerged from the African continent many thousands of years ago, every part of the world has been subject to overlapping waves of immigration. It has thus been a central part of human history - shaping and reshaping societies, cultures and economies. The twenty-first century is no exception. The millions of migrants who circulate around Asia or Africa, or who travel from developing to developed countries today, are just the latest bearers of an age-old tradition.

60. Even so, migration, and particularly immigration, has often been a controversial issue; indeed, the descendants of previous generations of immigrants, the "natives", look askance at the arrival of newcomers whom they consider a threat to their jobs or their culture. Even the United States, a country populated almost entirely by immigrants, has at times raised higher barriers to immigration, typically on the grounds that the contemporary generation of immigrants was in some way inferior to those who arrived 20, 50 or 100 years ago - objecting at various times to the arrivals of Irish, for example, or Chinese, or Eastern Europeans.

61. There have usually been fewer problems with emigration. Relatively few governments have objected to the departure of their citizens, and have done so on political rather than economic or social grounds. More often they have viewed emigration as a form of safety valve, allowing, sometimes encouraging, discontented or disadvantaged people to seek their fortunes elsewhere.

62. What impact does immigration have on national development? In some ways this is the wrong question. Migration, whether within or between countries, is better thought of as a part or an aspect of development - more significant at some times and in some countries than others, sometimes a cause of events, sometimes a consequence of them, but always an integral part of the development process. Nevertheless, as with many aspects of development, there are both positive and negative consequences. Table 2.1 lists some of the potential advantages of migration at three different levels - for the migrants themselves, for enterprises, and for the country as a whole. 
Table 2.1. Potential advantages and disadvantages of emigration and immigration

\begin{tabular}{|c|c|c|c|c|}
\hline & \multicolumn{2}{|l|}{ Emigration } & \multicolumn{2}{|l|}{ Immigration } \\
\hline & $\begin{array}{l}\text { Potential } \\
\text { advantages }\end{array}$ & $\begin{array}{l}\text { Potential } \\
\text { disadvantages }\end{array}$ & $\begin{array}{l}\text { Potential } \\
\text { advantages }\end{array}$ & $\begin{array}{l}\text { Potential } \\
\text { disadvantages }\end{array}$ \\
\hline \multirow[t]{5}{*}{$\begin{array}{l}\text { For migrants, } \\
\text { or for individuals }\end{array}$} & Employment & $\begin{array}{l}\text { Discontinuity, } \\
\text { loss of seniority }\end{array}$ & $\begin{array}{l}\text { Services that free women } \\
\text { to enter labour force }\end{array}$ & $\begin{array}{l}\text { Competition for jobs; } \\
\text { marginalization of } \\
\text { less skilled }\end{array}$ \\
\hline & Greater income & $\begin{array}{l}\text { Bad working/living } \\
\text { conditions }\end{array}$ & $\begin{array}{l}\text { Cheaper goods } \\
\text { and services }\end{array}$ & Lower local wages \\
\hline & Training or education & $\begin{array}{l}\text { Lower status work; } \\
\text { loss of skills }\end{array}$ & & Crowded schools \\
\hline & $\begin{array}{l}\text { New cultural } \\
\text { experiences }\end{array}$ & $\begin{array}{l}\text { Racism or } \\
\text { discrimination }\end{array}$ & Richer cultural life & $\begin{array}{l}\text { Strange languages } \\
\text { and customs }\end{array}$ \\
\hline & Meeting new people & $\begin{array}{l}\text { Separation from } \\
\text { family; } \\
\text { adverse impact } \\
\text { on children }\end{array}$ & $\begin{array}{l}\text { Learning about } \\
\text { other countries }\end{array}$ & \\
\hline \multirow[t]{3}{*}{ For enterprises } & $\begin{array}{l}\text { Skills of returning } \\
\text { migrants }\end{array}$ & $\begin{array}{l}\text { Losing skilled } \\
\text { workforce }\end{array}$ & $\begin{array}{l}\text { Cheaper, more } \\
\text { flexible labour }\end{array}$ & $\begin{array}{l}\text { Less stable } \\
\text { workforce }\end{array}$ \\
\hline & $\begin{array}{l}\text { Lucrative business } \\
\text { for the recruitment } \\
\text { industry }\end{array}$ & $\begin{array}{l}\text { Labour shortages } \\
\text { that drive up wages }\end{array}$ & Workforce diversity & $\begin{array}{l}\text { Dependence on } \\
\text { foreign labour for } \\
\text { certain jobs }\end{array}$ \\
\hline & $\begin{array}{l}\text { Extra business for } \\
\text { communications } \\
\text { and travel firms }\end{array}$ & & $\begin{array}{l}\text { Larger markets and } \\
\text { economies of scale }\end{array}$ & \\
\hline \multirow[t]{6}{*}{$\begin{array}{l}\text { For the country } \\
\text { as a whole }\end{array}$} & $\begin{array}{l}\text { Reduced population } \\
\text { pressure }\end{array}$ & $\begin{array}{l}\text { Losing younger } \\
\text { people }\end{array}$ & Rejuvenating population & Social friction \\
\hline & $\begin{array}{l}\text { Lower } \\
\text { unemployment }\end{array}$ & $\begin{array}{l}\text { Coping with sudden } \\
\text { returnees }\end{array}$ & $\begin{array}{l}\text { Larger workforce; } \\
\text { lower inflation }\end{array}$ & $\begin{array}{l}\text { Delay technology } \\
\text { upgrading }\end{array}$ \\
\hline & $\begin{array}{l}\text { Foreign currency } \\
\text { remittances }\end{array}$ & $\begin{array}{l}\text { Loss of potential } \\
\text { output and tax } \\
\text { revenue }\end{array}$ & $\begin{array}{l}\text { Higher GDP; } \\
\text { capital brought by } \\
\text { immigrant investors }\end{array}$ & $\begin{array}{l}\text { Increased income } \\
\text { inequality }\end{array}$ \\
\hline & $\begin{array}{l}\text { Knowledge and } \\
\text { skills of returnees }\end{array}$ & $\begin{array}{l}\text { Brain drain and } \\
\text { loss of better } \\
\text { workers; } \\
\text { reduced R \& D }\end{array}$ & Brain gain & $\begin{array}{l}\text { Costs of integration } \\
\text { programmes }\end{array}$ \\
\hline & $\begin{array}{l}\text { Building transnational } \\
\text { communities }\end{array}$ & $\begin{array}{l}\text { Social disruption } \\
\text { and a culture of } \\
\text { emigration }\end{array}$ & $\begin{array}{l}\text { More diverse and } \\
\text { energetic population }\end{array}$ & $\begin{array}{l}\text { More social } \\
\text { stratification; } \\
\text { immigrant ghettos }\end{array}$ \\
\hline & & Increasing inequality & $\begin{array}{l}\text { Tax income from } \\
\text { younger workers }\end{array}$ & $\begin{array}{l}\text { Cost of social } \\
\text { services, welfare } \\
\text { benefits }\end{array}$ \\
\hline
\end{tabular}

\subsection{Impact of migration on countries of origin}

63. While there can be many motivations behind individual decisions to migrate, it is evident that lack of satisfactory opportunities at home is the main driving force behind the contemporary growth of migration pressures. In the developing countries decent jobs 
are not being created fast enough to absorb the growing numbers of people joining the labour force every year. The ILO estimates that at the end of 2003, the number of working people earning US\$1 or less a day remained constant at the 2002 level of around 550 million.

64. The failure of the global economic system to generate jobs where there are people has put the onus of adjustment on the family and its members. In poor countries families have to make the hard decisions of sending a family member abroad to be able to cope with threats to their security which originate from many sources - natural calamities, external economic shocks, rapidly declining agricultural commodity prices, privatization and downsizing of state enterprises, currency devaluations, and bank failures. This explains why many migrate, often knowing it will involve great personal sacrifice, working in difficult conditions, and spending very little of their earnings so that they can send most of their savings home to their families.

65. Policy-makers in most developing countries seem to conclude, however, that - in the short term at least - migration has had a favourable net effect on their countries. Migration has absorbed a considerable number of young people entering their labour markets, while also generating large flows of remittances. Set against this primarily is the anxiety that they are losing some of their brightest young people in the form of a "brain drain". But for the major migrant source countries, emigration is generally seen as making a net contribution to development.

\section{(a) Reducing population pressure and unemployment}

66. Emigration may be perceived as helping to ease population pressures, but for most countries it can at best only have a modest impact. Even for the major sending countries, the proportion of the population leaving is relatively small. The largest transfer is from Mexico to the United States. Of the 108 million people alive today who were born in Mexico, around 8 million now live in the United States - effectively reducing Mexico's annual population growth rate from 1.8 to 1.5 per cent. ${ }^{1}$ For most other countries, such as China and India, the proportions are of course much lower.

67. The same is true of the impact of emigration on unemployment or underemployment in most countries of origin. Certainly if all the emigrants suddenly returned home there would be a serious problem - as was evident after the first Gulf War in 1990, when around 2 million foreign workers were driven out of Kuwait and Iraq and tried to find work in their countries of origin. Indeed, some of the countries with high net emigration rates are also the ones with intractable unemployment problems.

\section{(b) Emigration of skilled persons - The brain drain}

68. Since the early 1990 s the international mobility of highly skilled workers has been increasing ${ }^{2}$ with the rising global demand for skills, alongside advances in globalization and phenomenal growth in information and communications technologies (ICT). The impact of this "brain drain" on sending countries is still unclear; it obviously varies according to the characteristics of the country of origin (e.g., size and level of

\footnotetext{
${ }^{1}$ P. Martin and M. Teitelbaum: Emigration and development: Focus on West-Central Mexico, Report of the Eighth Migration Dialogue Seminar, Guadalajara, Mexico (2000).

${ }^{2}$ B.L. Lowell and A.M. Findlay: Migration of highly skilled persons from developing countries: Impact and policy responses - Synthesis report (Geneva, ILO, International Migration Paper IE, 2002); OECD: International mobility of the highly skilled (Paris, 2002).
} 
development), the type of sector or occupation concerned, the mode of financing education (e.g., public or private) and the type of migration (e.g., temporary, permanent, circular). ${ }^{3}$

69. Professionals move for many reasons, including higher wages, better facilities, and more opportunities for advancement. Receiving States also promote professional immigration through recruitment drives and selection systems that facilitate their entry. These selection systems are effective in attracting the best and brightest from developing countries, so that immigrants in the United States in 1990 from many developing countries had twice as much education as their compatriots at home. Table 2.2 shows that there were 3.7 times more Jamaicans with tertiary education in the United States than there were at home in 2000, while for every ten El Salvadorian college graduates at home there were four in the United States. The IOM has estimated that, for 40 per cent of African countries, at least one-third of college graduates are living abroad.

\section{Table 2.2. Migrants to the United States by level of educational attainment in} relation to similarly educated cohorts remaining at home, 2000 (\%)

\begin{tabular}{|c|c|c|c|c|}
\hline \multirow[b]{2}{*}{ Country } & \multirow[b]{2}{*}{ Total } & \multicolumn{3}{|l|}{ Educational level } \\
\hline & & Primary or less & Secondary & Tertiary \\
\hline \multicolumn{5}{|l|}{ East Asia } \\
\hline China & 0.1 & 0.1 & 0.2 & 2.2 \\
\hline Indonesia & 0.1 & 0.1 & 0.1 & 0.7 \\
\hline Philippines & 3.6 & 0.6 & 2.2 & 11.7 \\
\hline \multicolumn{5}{|c|}{ Eastern Europe, Central Asia } \\
\hline Croatia & 1.2 & 0.4 & 1.2 & 4.7 \\
\hline Turkey & 0.2 & 0.1 & 0.4 & 1.3 \\
\hline \multicolumn{5}{|c|}{ Latin America and the Caribbean } \\
\hline Brazil & 0.2 & 0.1 & 0.5 & 1.1 \\
\hline Colombia & 2.1 & 0.4 & 4 & 9.9 \\
\hline Dominican Republic & 12.9 & 5.3 & 42.4 & 24.8 \\
\hline El Salvador & 24.3 & 12.4 & 114.8 & 39.5 \\
\hline Guatemala & 7.6 & 3.8 & 29.9 & 25.8 \\
\hline Jamaica & 33.3 & 4.7 & 40.9 & 367.6 \\
\hline Mexico & 13.3 & 10.8 & 17.2 & 16.5 \\
\hline Peru & 1.8 & 0.3 & 2.5 & 4.2 \\
\hline \multicolumn{5}{|l|}{ Middle East, North Africa } \\
\hline Egypt & 0.3 & 0.1 & 0.2 & 2.3 \\
\hline Tunisia & 0.1 & 0.1 & 0.2 & 1.3 \\
\hline \multicolumn{5}{|l|}{ South Asia } \\
\hline Bangladesh & 0.1 & 0.1 & 0.3 & 2.3 \\
\hline India & 0.2 & 0.1 & 0.2 & 2.8 \\
\hline Pakistan & 0.3 & 0.1 & 0.5 & 6.4 \\
\hline Sri Lanka & 0.2 & 0.1 & 0.1 & 5.6 \\
\hline
\end{tabular}




\begin{tabular}{|c|c|c|c|c|}
\hline \multirow[b]{2}{*}{ Country } & \multirow[b]{2}{*}{ Total } & \multicolumn{3}{|l|}{ Educational level } \\
\hline & & Primary or less & Secondary & Tertiary \\
\hline \multicolumn{5}{|c|}{ Sub-Saharan Africa } \\
\hline Sudan & 0.1 & 0.1 & 0.3 & 3.4 \\
\hline \multicolumn{5}{|c|}{$\begin{array}{l}\text { Note: Immigrants defined as foreign-born population in the United States age } 25 \text { years or over; primary education or less } \\
\text { corresponds to 0-8 years of schooling; secondary to } 9-12 \text { years of schooling; and tertiary to more than } 12 \text { years of schooling. } \\
\text { Percentages represent ratio of numbers living in the United States over those living at home with same educational } \\
\text { attainment. } \\
\text { Source: Reproduced from table 5, R.H. Adams: International Migration Remittances and the Brain Drain: A study of } 24 \text { labour- } \\
\text { exporting countries, Working Paper No. } 3069,27 \text { May } 2003 \text {. }\end{array}$} \\
\hline
\end{tabular}

70. The brain drain can set in motion vicious circles that slow development. For example, the emigration of African doctors and nurses leads to poorer health care in Africa at a time when there is a greater need for it because of HIV/AIDS and recent initiatives to improve immunization rates. Emigration especially leaves rural areas with few health care staff, increases the work load on remaining staff, and may slow changes in the health-care system. Countries such as Jamaica and Ghana have more doctors trained locally outside the countries than inside them.

71. One estimate suggests that there are at least 400,000 scientists and engineers from developing countries working in research and development in the industrial countries compared with around 1.2 million still working at home. ${ }^{4}$

72. Student migration is a precursor to the brain drain. The OECD reported that in 2000 there were some 1.5 million foreign students pursuing higher studies in member States, of which over half came from non-member countries. In the United States there were 475,000; in the United Kingdom 223,000; in Germany 187,000; and in Australia 105,000 . Most aim to stay only for the duration of their study but a significant proportion end up staying as permanent migrants. Around 47 per cent of foreign-born $\mathrm{PhD}$ graduates remain in the United States, although the ratio varies between different source countries: between 1990 and 1999 the stay rates of foreign science and engineering $\mathrm{PhD}$ graduates were higher among migrants from China ( 87 per cent), India ( 82 per cent) and the United Kingdom (79 per cent), than among those from Taiwan, China (57 per cent) or the Republic of Korea (39 per cent). ${ }^{5}$

73. How damaging is this brain drain? There are both costs and benefits. ${ }^{6}$ One cost is that those who leave their countries of origin are often the best and the brightest - so their departure reduces the country's capacity for long-term economic growth. For countries that lose a significant part of their skilled labour force this could lower the returns to capital. Local firms that invest in training people will also find it hard to recoup their investments if these trained workers regularly leave. The emigration of highly trained people - given that it tends to have cumulative effects - may make it very difficult to create a critical mass of know-how necessary for product development and for adapting imported production technologies to local conditions. The history of industrialization points to the importance of internalizing knowledge and developing a capacity at enterprise levels for process and product innovation. Such possibilities are

\footnotetext{
${ }^{4}$ J.-B. Meyer and M. Brown. Scientific Diasporas: A new approach to the brain drain (Discussion Paper No. 41 prepared for the World Conference on Science, UNESCO-ICSU, Budapest, June-July 1999).

${ }^{5}$ OECD: International Mobility of the Highly Skilled (OECD Policy Brief, Paris, 2002).

${ }^{6}$ For an illustrative balance sheet of positive and negative impacts, see P. Wickramasekara: Policy responses to skilled migration: Retention, return and circulation (Geneva, ILO, International Migration Programme, Paper 5E, 2002).
} 
lost when the best workers and technicians are the first to take advantage of emigration opportunities.

74. The migration of the more highly skilled people might also affect capital movements. There could be an impact on foreign direct investment (FDI) since companies would take into account the skills and personnel available locally and might be discouraged from investing in a country that loses its most qualified people. In addition, migrants not only depart with their education, they also leave with significant amounts of capital. Again the destination countries encourage this. The United States immigrant investor programme, for example, permits 10,000 investors and members of their families a year to obtain immigrant visas if they invest at least US $\$ 500,000$ in the United States and create or preserve at least ten jobs. New Zealand offers visas to people who arrive with at least US\$630,000. For Canada, the corresponding sum is around US\$300,000.

75. Nevertheless, the outflow of educated people is not necessarily a damaging loss. ${ }^{7}$ ILO research on skilled emigration has shown that the net impact of skilled emigration from developing countries is a balance of direct and indirect effects. The most direct effect of skilled emigration is a reduction of human capital stock, which is critical to productivity and economic growth, but it also sets in play a number of forces that can promote economic growth through major feedback effects. Return migrants, in particular, bring back their skills and work experience from abroad, thus boosting productivity. The promise of higher incomes through migration may itself encourage more investment in education, public and private, than might otherwise have been the case. Expatriates who remain abroad contribute funds via remittances. They also transfer knowledge, technology, and investments to countries of origin, which boost productivity and economic development. A central challenge for developing countries would be to engage appropriately in the exchange of skills taking place in the global labour market. ${ }^{8}$

76. The large-scale emigration of IT workers from Asia, particularly India, has had a number of salutary effects on source countries in the form of skills transfer, outsourcing arrangements and investment flows. This has been described as a virtuous circle, in contrast to the vicious circle - described above - in the case of emigration of health workers from countries such as South Africa. Aside from remittances, there have been few benefits from the latter for the home countries. ${ }^{9}$ In the Philippines, the high salaries offered abroad for nursing graduates is even enticing some medical doctors to leave their jobs and apply for nursing jobs. The potential negative impact of emigration on the supply of human capital also needs to be seen in the overall context of employment in the country of origin. In many cases, expatriated professionals would have had few opportunities to work at home in their field. Many developing countries have more graduates in certain subjects than they need. In Bulgaria, for example, some 818,000 (or 19.3 per cent of its population) were graduates of tertiary education, a proportion much higher than those of other countries with per capita incomes more than two and a half times its own like the Czech Republic. ${ }^{10}$

\footnotetext{
${ }^{7}$ B.L. Lowell and A. M. Findlay, op. cit.; P. Wickramasekara, ibid.

${ }^{8}$ Lowell and Findlay, ibid.

9 P. Martin: Professional migrants and development, Paper presented at the GTZ Conference on Migration and Development, 20-21 October 2003, Berlin.

10 A. Gächter: The ambiguities of emigration: Bulgaria since 1988 (Geneva, ILO, International Migration Paper $39,2002)$.
} 


\section{(c) Social costs}

77. The social costs of labour migration in terms of fractured families and communities are without a doubt at least as significant as those related to the more measurable economic costs. The effects are almost never gender-neutral. In parts of South Africa, when a man leaves to work on mines and plantations, the wife left behind effectively becomes the head of a one-parent family. Similarly, in Kerala in India, there are around 1 million "Gulf wives". On the other hand, when it is the mother who migrates, the consequences for the family can be even more serious. In Sri Lanka, more than half a million women work in the Gulf and elsewhere. This has many implications for the family and community left behind - particularly for the children. Often the children of migrant women workers drop out of school or find themselves in vulnerable situations of neglect and abuse, including incest. On their return, some women also face traumatic experiences, such as sexual abuse, violence or family dislocation. More generally, countries that send a large proportion of their population overseas find they create a "culture of emigration" in which becoming a migrant is almost a rite of passage for young people. This is the case in a number of Caribbean countries, and increasingly in parts of Mexico and Uruguay.

\section{(d) Flows of remittances}

78. The recent World Bank study, Global Development Finance 2003, ${ }^{11}$ highlighted the fact that remittance flows were the second-largest source, behind FDI, of external funding for developing countries. In 2001, workers' remittance receipts of developing countries stood at US\$72.3 billion or 1.3 per cent of their combined GDP, much higher than total official flows and private non-FDI flows, and 42 per cent of total FDI flows to these countries. Flows of remittances were smaller than inflows of FDI but usually larger than those of official development assistance. They were also a more reliable and stable source of income and tended to fluctuate less with economic cycles - they continued to rise during the Asian financial crisis, for example, even when flows of FDI fell (figure 2.1). For a number of countries remittances are now the principal source of foreign exchange.

79. Whether intended for consumption or for investments, migrants' remittances appear to be less volatile than capital flows. In fact remittances tend to increase in times of economic hardship because families depend on them as a principal income source, and because more people are likely to emigrate for work during such times. Better-off migrants who invest in their home countries are also less likely to be discouraged by adverse economic conditions than foreign investors. The World Bank noted that remittances have been used as collateral against which some emerging market economies like Brazil borrow in the international capital markets on substantially better terms than they otherwise could.

\footnotetext{
${ }^{11}$ World Bank: "Workers' remittances: An important and stable source of external development finance", by D. Ratha, in Global Development Finance 2003 (Washington, DC, 2003).
} 


\section{Figure 2.1. Workers' remittances and other inflows, 1998-2001 (US\$ billion)}

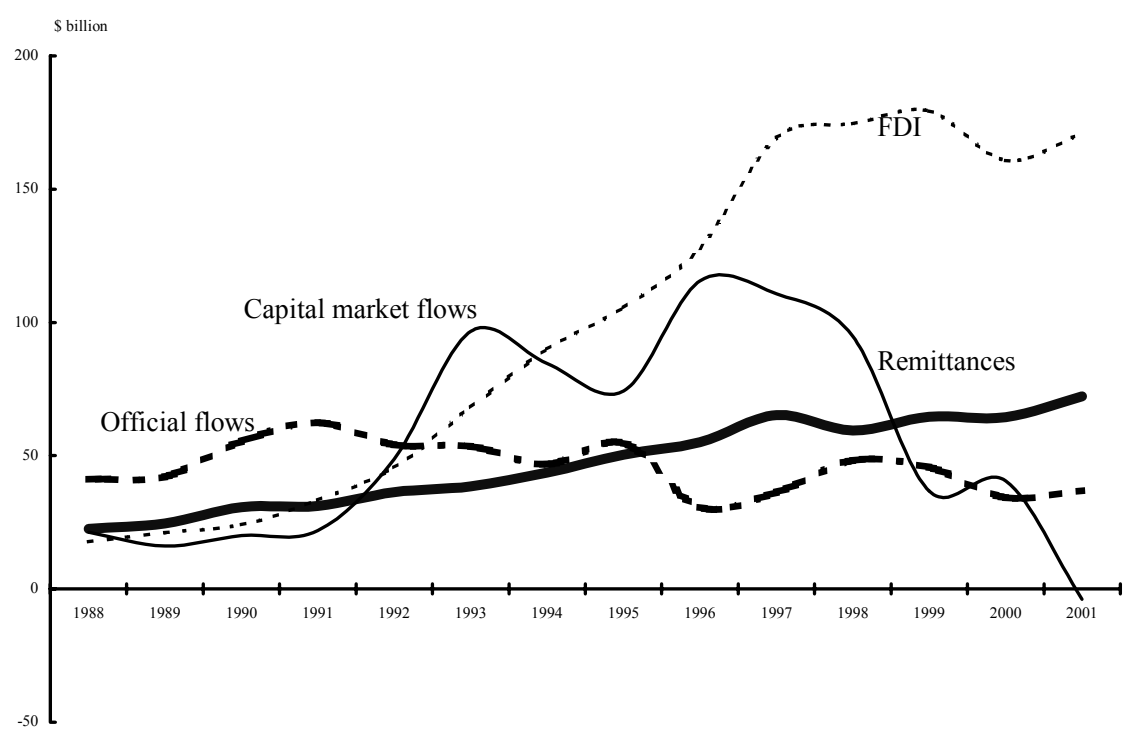

Source: World Bank, Global Development Finance 2003 (Washington, DC, 2003) p. 158.

80. While there is no information on remittance flows according to the skill profile of migrant workers, the contribution of low-skilled migrants is believed to be substantial. An undocumented Mexican worker in the United States, for example, is estimated to send back home US $\$ 500$ per month. Although the leading recipients of remittances were Mexico (US\$10 billion), India (US\$9.9 billion) and the Philippines (US\$6.4 billion), remittances as a share of GDP were much higher in some of the smaller countries: Tonga (37 per cent), Lesotho (27 per cent), the Republic of Moldova (25 per cent), and Jordan (23 per cent). ${ }^{12}$ In Cape Verde, remittances exceeded the country's exports by 16 to one in 1994. In the same year, remittances accounted for over 75 per cent of merchandise exports in Egypt, El Salvador and Jordan, and 25 per cent or more of merchandise exports in Bangladesh. ${ }^{13}$ ILO case studies show that remittances in Bangladesh account for more than half of household income of families who receive them, and in Senegal the figure is as high as 90 per cent. A recent ILO mission to Nepal concluded that remittances now probably contribute more to Nepal's foreign exchange than do manufacturing exports, tourism, foreign aid and other sources combined. Research has suggested that the resilience of the economy despite these adverse macroeconomic indicators must be due to the inflow of the large volume of remittances, estimated at more than one billion rupees each year.

81. Even these amounts only refer to official transfers. In some countries it is thought that only around half of remittances pass through official banking channels, since migrants are discouraged from using them by cumbersome procedures, high fees and poor rates of exchange. In South Asia, the Hawala or Hundi systems of informal transfer are popular because they make it much easier for people not used to going to banks to receive money sent to them. Allowing for the funds that do not travel through formal

\footnotetext{
12 ibid.

13 J. Van Doorn: "Migration, remittances and development", in Labour Education 2002/4 (Geneva, ILO, 2003), No. 129, special issue on migrant workers, pp. 48-53.
} 
banking channels, the global annual flow of remittances to developing countries probably already exceeds US $\$ 100$ billion.

82. An unexpected consequence of the large flows of migrants' remittances through informal currency traders is the ease with which capital flight takes place during periods of instability. In many developing countries large amounts of foreign currencies are now traded by money brokers who easily escape control by the monetary authorities.

83. It is difficult to generalize as to how increased remittances by migrants have affected the development of origin countries. Since they tend to push up the external value of a country's currency or its exchange rate, they may make a country's exports less competitive and investments in import-substituting industries less attractive, a variant of the so-called "Dutch disease". But most origin country authorities seem convinced that this impact has on the whole been very positive, especially because of the need for foreign exchange to finance large trade deficits and service external debts.

84. Since remittances go directly to migrants' households which have a high propensity to consume, their multiplier effects on a country's national income is considerable. Increased spending by migrants' families on goods and services produced in sectors with excess capacity create jobs and incomes for others whose additional spending in turn benefits some others, and so on. A study by the Bangladesh Institute of Development Studies, for example, indicates that remittances in Bangladesh have a multiplier effect of 3.3 on GNP, 2.8 on consumption, and 0.4 on investment. ${ }^{14}$

85. The recent Department for International Development (DFID) and World Bank International Conference on Migrant Remittances concluded that sound macroeconomic policies, political stability and improvements in the investment climate in receiving countries were prerequisites for making the best use of remittances. It suggested that improving migrants' access to the formal financial sector constituted a priority because the formalization of transfers was central to enhancing their long-term development impact. $^{15}$

\section{(e) Transnational communities and home country development}

86. Migration is viewed positively in origin countries not only because it improves the economic conditions of migrant families and their communities but also because migration and return have become conduits for new ideas and new ways of doing things, and serves as a window to the outside world. In addition to sending remittances, migrant communities abroad are now seen as investors, welfare providers, knowledge communities and technology harbingers to the home countries. They can do this, for example, by passing on information and contacts and helping to enforce contractual arrangements. Indian nationals who have reached senior executive positions in multinational companies such as Hewlett Packard have encouraged their companies to set up operations in India. Studies undertaken by the Sussex Migration Centre on Ghana and Côte d'Ivoire have shown that migration and return can be seen as a mechanism for providing capital for the development of small enterprises, particularly among poorer

\footnotetext{
14 ibid.

15 DFID/World Bank: Report and conclusions; International Conference on Migrant Remittances: Development impact, opportunities for the financial sector, and future prospects (London, 9-10 October 2003).
} 
and less-skilled migrants. ${ }^{16}$ Some US\$60 billion are estimated to have been invested in China by 55 million overseas Chinese.

87. Governments of origin countries are increasingly becoming interested in the potential value of transnational communities as engines of development. Mexico, for example, has created special programmes that match government funds to remittances that were invested to create jobs in migrant areas of origin. Mexicans in the United States have thousands of "hometown associations", which have supported all kinds of community activity back home, from building new roads to repainting the church to paying for fiestas. Similarly, emigrants from El Salvador who live in Los Angeles, Washington, DC, and many other United States cities have established comités del pueblo (town committees) to support activities back home. Salvadorian towns with this kind of association often acquire paved roads and electricity.

88. The migrants themselves have formed associations and networks abroad, some of which are associations of the intellectual or professional diaspora. Meyer and Brown ${ }^{17}$ have identified 41 formal knowledge networks linking thirty countries to their skilled nationals abroad. They distinguish between five types of networks: student/scholarly networks, local associations of skilled expatriates, expert pool assistance through the UNDP's TOKTEN programme, and intellectual/scientific diaspora networks. Some well-known ones are: the Colombian Red Caldas network, the South African Network of Skills Abroad (SANSA), the Global Korean Network, the Philippines Brain Gain Network, Polish Scientists Abroad, the Association of Thai Professionals in North America, the Iranian Scientific Information Network, the Tunisian Scientific Consortium, and Arab Scientists and Technologists Abroad. The Internet has played a key role in this regard, and SANSA, for example, is said to comprise an active network with more than 2,000 members. ${ }^{18}$

\section{(f) Return migration}

89. The large-scale return of migrants has rarely taken place before conditions at home have improved sufficiently to make it attractive. This happened when northern Italy became very prosperous and attracted back Italians who had earlier migrated to Germany and the Americas; in the Russian Federation, when ethnic Russians who had earlier been forcibly relocated to Central Asia and the Caucasus moved back after the collapse of the Soviet Union; and when second-generation Japanese in Brazil, Peru and elsewhere in Latin America responded to encouragements for them to take up jobs in Japan.

90. Individual migrants, however, do return even when conditions at home have not changed - either because their contracts abroad are over or because they have other reasons for not wanting to remain abroad. This is clearly the case for temporary migrants such as most contract workers in the Gulf States, who normally return after a couple of years. On the other hand, many other people who migrate overseas with the aim of longterm settlement change their minds after a couple of years. One survey has concluded

\footnotetext{
${ }^{16}$ Sussex Centre for Migration Research: International Workshop on Migration and Poverty in West Africa, Sussex University, Brighton, 2003.

17 J.-B. Meyer and M. Brown: Scientific diasporas: A new approach to the brain drain (Paris, UNESCO, UNESCO-MOST Discussion Paper No. 41, 1999).

${ }^{18}$ H. Bhorat, J.-B. Meyer and C. Mlatsheni: Skilled labour migration from developing countries: Study on South and Southern Africa (Geneva, ILO, International Migration Papers No. 52, 2002).
} 
that around 20 per cent of migrants to the United States leave within ten years of arrival and one-third leave at some time during their lifetime. ${ }^{19}$

91. Some migrants may have been disappointed by their emigration experience; others may decide to return when they have accumulated sufficient funds. But often the deciding factor will be the situation in their country of origin: if the economic outlook improves then returning will seem more attractive. When these migrants come back with skills or savings, this can make a welcome contribution to development. China, for example, is now taking advantage of what are sometimes called "turtles" - comparing returning migrants to turtles who eventually return to the beach where they were born. Of the 600,000 students who are thought to have left China in the past 25 years only 160,000 have returned. But the numbers are rising: 18,000 in 2002, double the number of two years previously - of whom a high proportion held a master's degree or a doctorate, and many of whom set up new enterprises in business parks created for their use. ${ }^{20}$

92. In addition to those who return home permanently there are also people who regularly move back and forth between their two countries. In this case, rather than a brain drain, there is more of a circulation or sharing of know-how. Indeed the extent of travel and communications links between source and destination countries is blurring lines of nationality. Migrants, diasporas and circulating workers have effectively been establishing new kinds of social space and forming "transnational communities". The African Union has now invited Africa's diaspora to actively take part in the region's development, and has agreed to amend the organization's charter to "encourage the full participation of the African diaspora as an important part of the continent....". ${ }^{21}$

\section{(g) Migration and trade}

93. Trade, like migration, also involves the movement of labour since goods traded include labour inputs. For this reason economists look at trade as a substitute for migration. It is therefore not surprising that the growth of trade with the reduction or removal of tariffs and other trade barriers tends to reduce migration pressures. In the European Union the growth of intra-community trade has brought about a convergence of incomes. Today, even though labour is completely free to move within the European Union, the number of workers tempted to migrate is an insignificant proportion of the European workforce because trade and other measures have largely accomplished the job of reducing economic differences between the Member States. ${ }^{22}$ The relation between trade and migration is, however, much more complex than this would suggest. Some activities like "call centres" can easily be relocated to low-wage countries (jobs migrate, not labour), but others cannot. In some cases - such as financial services and hightechnology products - trade and migration are complementary in that the former prompts an increase of the latter.

94. Other factors also influence outcomes. In North America, NAFTA may in fact have led to greater, not less, migration between the United States and Mexico. The

\footnotetext{
19 B. Bratsberg and D. Terrell: "Where do Americans live abroad?", in International Migration Review (New York), 1996, Vol. 30, No. 3.

20 "On their way back", in The Economist (London), 19 Nov. 2003.

${ }^{21}$ G. Mutume: "Reversing Africa's "brain drain": New initiatives tap skills of African expatriates", in Africa Recovery (New York, United Nations), Vol. 17, No. 2, July 2003.

${ }^{22}$ See A. Venables: "Trade liberalization and factor mobility: an overview", in R. Faini, K.F. Zimmerman, J. de Melo (eds.), Migration: The controversies and the evidence (London, Cambridge University Press, 1999).
} 
establishment of maquiladora enterprises near the United States-Mexico border has triggered labour migration from the Mexican hinterland - which in turn has generated more pressures to cross the border for much higher wages.

95. As noted earlier, migration and remittances may in turn have a perverse impact on trade. Where remittances raise the exchange rate of the currency of the country of origin, the consequence may be to reduce exports and increase imports. Some countries have been labelled as "import-based, remittance-dependent economies" for this reason.

96. Migrants do contribute to trade by establishing stronger links between the source and destination countries. The most striking example of this synergy is provided by the Indian information technology (IT) industry. Initially the Indian Government had not been enthusiastic about information technology, fearing job losses. But multinationals in India recognized the IT talent in India and sent Indians to their operations in other countries. Meanwhile, Indian firms such as Tata moved Indian IT specialists overseas and soon saw the virtues of bringing some back to work in India. The Indian Government then bolstered the budding IT industry by reducing barriers to the imports of computers and helped to assure reliable infrastructure. By 2002, India had about US $\$ 10$ billion in revenues from exports of computer-related products, including services provided to foreign firms in India, and has gradually been moving from exporting labour to exporting services.

97. The General Agreement on Trade in Services (GATS) from the Uruguay Round represents the first multilateral and legally enforceable agreement on the international trade in services. Its central objective is the progressive liberalization of trade in services. GATS Mode 4 (movement of natural persons) in a sense seems to provide the best of both worlds for promoting circulation of skills - at least in theory. On the one hand, developing countries have surplus skills in the service sector, and GATS provides an opportunity for them to earn higher rewards in developed countries. On the other hand, the strictly temporary movement of Mode 4 of GATS allays the concerns of developed countries about permanent settlement. Yet the potential of this option has been seriously constrained by limited commitments by developed countries, and by serious immigration barriers to the movement of natural persons. Confusion of short-term movements with permanent migration, and treatment of issues within a migration rather than a trade framework, have hampered progress in this area. ${ }^{23}$

\section{(h) Migration and overall economic performance}

98. Migration may clearly have a number of positive and negative effects in the country of origin. Most policy-makers in developing countries conclude that any losses in human capital are more than offset by the gains through remittances and other linkages. Is this the case? At present, there is not much positive evidence that countries receiving large quantities of remittances have better economic performance. Of the top 20 developing country recipients of workers' remittances, seven have managed an annual per capita income growth of at least 2 per cent over the past 25 years (notably China, India, and Thailand); however, seven have done very poorly (notably Ecuador, the Philippines and Yemen).

\footnotetext{
${ }^{23}$ OECD and Working Party of the Trade Committee: Service providers on the move: A closer look at labour mobility and the GATS (Paris, OECD, 2002).
} 
99. A similar mixed picture emerges when economic performance is compared with net migration rates. Table 2.3 groups developing countries by economic performance and by involvement in migration as reflected in net migration rates. This table excludes countries for which no migration data were available. It also excludes the least developed countries, for which structural factors would be far more important in explaining development performance than migration.

\section{Table 2.3. Emigration and development performance}

\begin{tabular}{llllllr}
\hline & High emigration & \multicolumn{4}{l}{ Medium emigration } & \multicolumn{2}{l}{ Low emigration } \\
\hline High performers & Guinea & $(-11.0)$ & Cape Verde & $(-2.2)$ & Thailand & $(-0.1)$ \\
& Lesotho & $(-4.0)$ & Belize & $(-1.2)$ & China & $(-0.3)$ \\
Rapidly growing per & & & Egypt & $(-1.2)$ & India & $(-0.2)$ \\
capita incomes $(2 \%+)$ & & & Uganda & $(-1.6)$ & Mauritius & $(0)$ \\
Medium performers & Samoa & $(-13.5)$ & Guatemala & $(-2.0)$ & Romania & $(-0.2)$ \\
& Guyana & $(-10.5)$ & Philippines & $(-2.3)$ & Bangladesh & $(-0.4)$ \\
Slow-growing per & Suriname & $(-7.8)$ & Morocco & $(-1.0)$ & & \\
capita incomes & Fiji & $(-8.3)$ & Peru & $(-2.2)$ & & \\
& Jamaica & $(-5.6)$ & Ecuador & $(-2.3)$ & & $(-0.2)$ \\
& & & Trinidad \& & $(-2.9)$ & & \\
& & & Tobago & & & \\
Poor performers & Albania & $(-19.0)$ & Latvia & $(-3.5)$ & Zimbabwe & \\
& Kazakhstan & $(-10.3)$ & Ukraine & $(-2.1)$ & & \\
Declining per capita & Tajikistan & $(-9.8)$ & Mongolia & $(-2.3)$ & & \\
incomes & Estonia & $(-6.0)$ & & & & \\
& Georgia & $(-9.7)$ & & & &
\end{tabular}

Note: The figures in brackets are net migration rates (migrants per thousand of the population), averaged over the period 2000 to 2005. A negative figure indicates emigration.

Source: M. Abella, paper presented at Metropolis Conference, Vienna, Sep. 2003. Net migration data are from United Nations Population Division: World Population Prospects: The 2002 Revision (New York, 2003).

100. Poorly performing economies tend to be concentrated in the column for high net emigration, while higher performing countries are in the column with lower net emigration rates. However, this crude comparison cannot indicate the direction of causality: are people leaving because the economic situation is difficult, or does their departure cause deterioration in economic performance? The former seems more likely. In the case of Eastern Europe, for example, the high emigration rates are probably the result of major social and economic disruption in the region. On the other hand, there does not seem to be any evidence that high emigration boosts economic performance. At best emigration can serve as a safety valve, making more productive use of workers who otherwise would have been unemployed or underemployed, or whose departure opens up employment opportunities for others.

101. Among the middle-income countries there does not seem to be a strong correlation between per capita income and migration. For example the Philippines, whose per capita income has only risen at 1 per cent a year over the past 20 years, has the same migration rate as Mexico whose economic performance has been much better. Clearly other factors are at work here. Mexico experiences a strong pull from the United States to the North, and cross-border migration is much easier than for the Philippines. In addition, the flight 
from the countryside and the high levels of inequality will have encouraged migration from Mexico. ${ }^{24}$

102. One recent review of the links between migration and development has concluded that it is still an "unsettled and unresolved" field. ${ }^{25}$ Whether or not emigration will contribute to development will vary according to many factors. It would seem to depend, for example, on what forms of migration take place, where to, and on how well countries are able to put in place policies to adjust to adverse consequences or take advantage of big windfalls. The latter suggests that migration can contribute positively to development where a country is already poised to develop; it cannot, however, create such a condition.

103. A recent study has attempted an assessment of the relationship between poverty, migration and remittances for 74 low and middle-income developing countries. ${ }^{26}$ The major finding is that both international migration (the share of a country's population living abroad) and international remittances (the share of remittances in country GDP) have a strong, statistical impact on reducing poverty in the developing world. First, "on average, a 10 per cent increase in the share of international migrants in a country's population will lead to a 1.6 per cent decline in the poverty headcount." ${ }^{27}$ Second, international remittances - defined as the share of remittances in country GDP - have a negative and statistically significant effect on poverty indicators used. On average, the point estimates for the poverty headcount measure indicate that a 10 per cent increase in the share of remittances in country GDP will lead to a 1.2 per cent decline in the share of people living on less than US\$1 per person per day. The other poverty measures - the poverty gap and squared poverty gap - show a slightly larger impact on poverty reduction, with a 2.0 per cent decline in the depth and/or severity of poverty in the countries studied. The study finds that the impact of international migration and remittances on poverty varies from one region to another, which may perhaps be due to the difficulty of factoring in undocumented migration.

\subsection{Impact of immigration on destination countries}

104. Immigration has equally profound consequences for receiving countries. The immediate effects are to rejuvenate populations and stimulate growth without inflation but these are seldom noticed. What usually become the subject of public discourse are the social adjustments that receiving societies have to make to immigrants from a different ethnic origin, whose values may differ considerably from their own. Many societies have managed to adjust to increasing immigration and some, like Canada, may even celebrate increasing diversity. There is today much greater cultural diversity, even in countries which a decade or so ago did not see themselves as countries of immigration. But there have been some negative reactions, sometimes taking the form of open racism and xenophobia, especially where migration is perceived, rightly or wrongly, to take away jobs from native workers. At another level migration, especially when large in

\footnotetext{
${ }^{24}$ X. Clark, T.J. Hatton and J.G. Williamson: What explains cross-border migration in Latin America? Draft paper, June 2003, p. 6. http://post.economics.harvard.edu/faculty/jwilliam/papers/Cross-Border.pdf (accessed 27 Feb. 2004).

25 D. Ellerman: Policy research on migration and development (Washington, DC, World Bank, World Bank Policy Research Working Paper 3117, 2003).

${ }^{26}$ R. Adams Jr. and J. Page: The impact of international migration and remittances on poverty, Paper prepared for the DFID/World Bank Conference on Migrant Remittances, London, 9-10 Oct. 2003.

${ }^{27}$ ibid.
} 
scale, may have important repercussions on the political order in the destination countries. Particularly where it does not lead to integration, migration is sometimes at the root of ethnic tensions.

105. While migration may bring about the same pressures on host societies, the outcomes have tended to differ, depending on a country's history, its policies, and its government's capacity for managing social change. It is not possible to speak of consequences without taking into account the mediating effects of state policy. The emergence of minority ghettoes, for example, is the consequence of failure of policy to integrate migrants, rather than the inevitable result of immigration. In some cases it may even result from well-intentioned policies to provide refugees and poor immigrants with subsidized housing.

106. At the economic level immigration also has a mixed impact on the destination countries, though here there seems little doubt that the countries as a whole benefit, even if certain groups find themselves disadvantaged - notably the less skilled, a group that includes some of the earlier migrants. In Europe since the Second World War, immigrant workers have been credited for their contribution to thirty or so years of sustained growth. In East and West Asia from the 1970s, migrant workers helped transform cities, almost overnight, into gleaming metropolises. And in North America immigrants to Canada and the United States have for generations renewed and re-energized the population and the economy.

107. An exercise for the destination countries, similar to that in table 2.2, would show that the countries with the highest levels of immigration are among the most successful economically - the United States, Canada, Australia and South Africa. In Europe, Germany, Switzerland and Luxembourg have some of the highest proportions of immigrant workers and are among the wealthiest. A statistical analysis for 15 European countries over the period 1991-95 found that for every 1 per cent increase in a country's population through immigration there was an increase in GDP of 1.25 to 1.5 per cent. ${ }^{28}$ This, of course, does not prove causality, but studies which used simulation models to assess the impact of migration on GDP indicate that it can be substantial if the skills of the migrants complement those of the native population. ${ }^{29}$

\section{(a) Impact on employment and wages}

108. It is commonly assumed that during times of economic expansion immigrants bring net benefits. This can come about for example by meeting general labour shortages and helping prevent inflation, and also by providing particular skills that are in great demand, as has happened in recent years with information technology specialists. In Europe, where countries have less mobile populations than the United States, these shortages can occur not just in different countries but also in different regions in the same country. Migrants tend to move to the fast-growing regions where wages are relatively higher and unemployment lower. It must also be noted that the impact of migration is not limited to the labour market; it can also provide incentives for capital accumulation. ${ }^{30}$

\footnotetext{
${ }^{28}$ S. Glover, C. Gott et al.: Migration: An economic and social analysis (London, Home Office, RDS Occasional Paper No. 67, 2001).

${ }^{29}$ H. Brücker, G. Epstein et al.: "Managing migration in the European welfare state", in: T. Boeri, G. Hanson and B. McCormick (eds.), Immigration policy and the welfare state (Oxford, Oxford University Press, 2002), p. 120.

30 ibid.
} 
109. The impact of migration on wages and employment depend on initial conditions in the labour market, and the number and skill levels of migrant workers admitted. In general immigration would tend to reduce the wages of natives with similar skills, and consequently also worsen income distribution. But studies in Western Europe indicate that wages tend to resist downward pressures and the impact on employment is ambiguous (table 2.4). Migration has had a negative impact on unskilled wages but may actually raise the real wages of the more skilled because of the increased supply of products from the low-wage sector.

Table 2.4. The employment impact of migration: A survey of European studies, 1992-2002

\begin{tabular}{|c|c|c|c|}
\hline Study & Year & Country & Impact on employment \\
\hline Gang and Rivera-Batiz & 1996 & EU-12 & $\begin{array}{l}\text { Positive, but insignificant correlation between } \\
\text { unemployment probability and foreigner density }\end{array}$ \\
\hline Gang and Rivera-Batiz & 1999 & EU-12 & $\begin{array}{l}\text { Weak, but significant positive correlation between } \\
\text { unemployment probability and foreigner density }\end{array}$ \\
\hline Hunt & 1992 & France & $\begin{array}{l}\text { An increase of the foreigner share by } 1 \text { percentage } \\
\text { point increases native unemployment rate by } 0.2 \\
\text { percentage points }\end{array}$ \\
\hline Mühleisen and Zimmermann & 1994 & Germany & $\begin{array}{l}\text { No significant impact of foreigner share on } \\
\text { unemployment probability }\end{array}$ \\
\hline Villosio and Venturini & 2002 & Italy & $\begin{array}{l}\text { Ambiguous signs for both, displacement risks and } \\
\text { entry probability }\end{array}$ \\
\hline Winkelmann and Zimmermann & 1993 & Germany & $\begin{array}{l}\text { No significant increase of unemployment frequency } \\
\text { of natives }\end{array}$ \\
\hline Winter-Ebmer and Zweimüller & 1994 & Austria & $\begin{array}{l}\text { An increase of the foreigner share by } 1 \text { percentage } \\
\text { point increases individual displacement risks by }-1 \text { to } \\
1.1 \text { per cent (instrumented), } 0.1 \text { to } 0.4 \text { per cent (not } \\
\text { instrumented) }\end{array}$ \\
\hline Hofer and Huber & 1999 & Austria & $\begin{array}{l}\text { An increase in the foreigner share by } 1 \text { percentage } \\
\text { point increases individual displacement risks by } 0.8 \\
\text { per cent }\end{array}$ \\
\hline Brücker, Schräpler and Kreyenfeld & 1999 & Germany & $\begin{array}{l}\text { An increase in the foreigner share by } 1 \text { percentage } \\
\text { point increases individual displacement risks by } 0.2 \\
\text { per cent }\end{array}$ \\
\hline Pischke and Velling & 1997 & Germany & $\begin{array}{l}\text { Weak correlation between foreigner share and } \\
\text { unemployment rate with ambiguous signs }\end{array}$ \\
\hline Winter-Ebmer and Zimmermann & 2000 & $\begin{array}{l}\text { Austria, } \\
\text { Germany }\end{array}$ & $\begin{array}{l}\text { An increase in the foreigner share by } 1 \text { percentage } \\
\text { point increases (decreases) total employment by } \\
-0.002 \text { per cent (Austria) and } 0.025 \text { per cent } \\
\text { (Germany), and native employment by }-0.25 \text { per } \\
\text { cent (Austria) and }-0.04 \text { per cent (Germany) }\end{array}$ \\
\hline
\end{tabular}

Note: Elasticities have been converted at the sample mean by the author.

Source: Courtesy of United Nations Economic Commission for Europe: Economic Survey of Europe, 2002, No. 2.

110. The presence of immigrants is generally assumed to depress wages for local workers. However, the near uniform finding of a wide range of studies is that any negative effect of immigration on wages is small. In Europe, there have been a series of studies that have produced a range of conclusions. A study in Germany in 1995 based on 
household panel data shows that a 1 per cent increase in the share of foreign citizens in the population has a small positive impact ( 0.6 per cent) on domestic wages. ${ }^{31}$ Wages of the highly skilled native workers increase even more, by 1.3 per cent. Other studies found negative but very small effects, ranging from -0.3 to -0.8 per cent, while some suggested that native wages, especially of the highly skilled, increase slightly. ${ }^{32}$ In the United States a large number of studies have concluded that there is very little impact typically concluding that a 10 per cent increase in the proportion of immigrants in a region lowers native wages by less than 1 per cent and often by an amount close to zero. ${ }^{33}$ A survey of literature in the United Kingdom concluded: "The overwhelming majority of empirical studies agree that there is essentially no statistically significant effect of immigration on labour market outcomes." 34

111. It is possible, however, that the arrival of immigrants in a given certain region either causes other workers to leave or deters them from coming, thus diffusing or disguising the impact. There are, on the other hand, other studies showing that, in terms of mobility, natives and previous cohorts of immigrants do not react in this way to new immigrant inflows - indeed, if anything, their arrival can complement new immigrant flows.

112. What does seem to be the case, however, is that the wages of immigrants as a whole are lower than those for native workers. In most EU countries, migrants, and particularly non-EU migrants, are more likely to be unemployed than natives. Although the situation varies from one country to another, the general picture seems to be that this is the result of lower levels of education and skill among immigrants. In the United States too, in 1998 the hourly wage for immigrant men was 23 per cent less than that for native men, largely because of the increasing concentration of immigrants with low levels of education. That is not to deny that part of the explanation is discrimination against immigrants. Many studies already confirm that visible minorities earn significantly less than natives, even when taking into account occupation, industry, education, experience and language, among other factors. ${ }^{35}$

113. There is much controversy as to whether or not immigration causes higher unemployment among natives. At micro or enterprise levels there are undoubtedly displacements that take place when firms restructure and foreign workers are hired to take the place of native workers, especially the older and less skilled, who have been laid off. What is difficult to assess is whether, after taking all economic adjustments into account, there is higher unemployment among natives after immigration than before. If immigration brings about an expansion of the economy it is no longer clear that it causes higher unemployment among natives. The OECD examined the experience of several countries between 1984 and 1995 and concluded that there was no evidence of a

\footnotetext{
${ }^{31}$ K. Zimmerman: Wage and mobility effects of trade and migration (London, CEPR Discussion Paper No. 1318, Jan. 1995).

${ }^{32}$ G. Hanson, K.F. Sheve et al.: "Immigration and the US economy: Labour-market impacts, illegal entry, and policy choices", in: T. Boeri, G. Hanson and B. McCormick (eds.): Immigration policy and the welfare system (Oxford, Oxford University Press, 2002, p. 192).

${ }^{33}$ H. Brücker, op. cit., p. 30.

${ }^{34}$ N. Gaston and D. Nelson: The employment and wage effects of immigration (Centre for Research on Globalisation and Labour Markets, University of Nottingham), July 2000, cited in Glover et al., op. cit.

35 See for example: K. Pendakur and R. Pendakur: "The colour of money - Earnings differentials among ethnic groups in Canada", in Canadian Journal of Economics, Vol. 31, No. 3, Aug. 1998.
} 
negative impact. In one study no relationship at all was found between unemployment and the growth in immigrant arrivals: in the countries that had the highest inflows of immigrants, unemployment often stayed the same or went down. Indeed some studies even show that immigration has led to an increase in employment as a result of an expansion in production. The admission of unskilled labour may, for example, lead to increased production of labour-intensive products and to increased exports, thus raising overall levels of employment. ${ }^{36}$

114. A direct way of examining whether immigration adds to unemployment during a recession is to compare two periods of time and see if an increase in immigration is matched by an increase in unemployment. The OECD has carried out this exercise for a range of countries for the periods 1984-89 and 1990-95. ${ }^{37}$ As may be seen in table 2.5, annual immigration and unemployment do not appear to be related. Migration grew rapidly between the two periods even if the latter witnessed a an economic downswing. In the countries that experienced a substantial increase in immigration (the United States, Germany, Japan, Switzerland and France) the rate of unemployment dropped in one, rose slightly in three, and remained the same in the fifth.

Table 2.5. Gross immigration inflows and unemployment in selected OECD countries

\begin{tabular}{|c|c|c|c|c|c|}
\hline & \multicolumn{2}{|l|}{ 1984-89 } & \multicolumn{2}{|l|}{$1990-95$} & \multirow{2}{*}{$\begin{array}{l}\text { Percentage point } \\
\text { difference in } \\
\text { unemployment } \\
\text { rates }\end{array}$} \\
\hline & $\begin{array}{l}\text { Average inflows } \\
\text { (thousands) }\end{array}$ & $\begin{array}{l}\text { Unemployment rate } \\
\text { (per cent) }\end{array}$ & $\begin{array}{l}\text { Average gross } \\
\text { inflows } \\
\text { (thousands) }\end{array}$ & $\begin{array}{l}\text { Unemployment rate } \\
\text { (per cent) }\end{array}$ & \\
\hline United States & 675 & 6.4 & 1128 & 6.4 & 0.0 \\
\hline Germany & 520 & 7.6 & 920 & 8.1 & +0.5 \\
\hline Japan & 183 & 2.6 & 284 & 2.5 & -0.1 \\
\hline Switzerland & 69 & 0.7 & 101 & 2.9 & +2.2 \\
\hline United Kingdom & 50 & 8.6 & 54 & 9.4 & +0.8 \\
\hline France & 45 & 10.0 & 93 & 10.7 & +0.7 \\
\hline Norway & 18 & 3.0 & 18 & 5.5 & +2.5 \\
\hline Luxembourg & 7 & 1.6 & 10 & 2.0 & +0.4 \\
\hline \multicolumn{6}{|c|}{ Note: Data for Germany are for Western Germany until 1990, and subsequently for Germany as a whole. } \\
\hline
\end{tabular}

115. Even at times of economic contraction, immigrants continue to do work that native workers shun. In many industrialized countries, the steadily more educated populations are less willing to take on manual work, even skilled manual work. In the Republic of Korea the Government wants more women and old people either to start working or to return to work. But most of the firms say this is impractical for heavy physical work. In any case they find that Koreans refuse to do even the lighter work for the wages on offer.

\footnotetext{
${ }^{36}$ A. Venables, op. cit.

37 OECD: Trends in International Migration: SOPEMI 1997 (Paris, 1998).
} 


\section{(b) Fiscal impact of immigration}

116. A major concern in some countries is that immigrants become a burden on host societies since they extract more from public services and welfare payments than they contribute in terms of taxes and social security contributions. ${ }^{38}$ In Denmark, the Netherlands, Belgium, France, Austria and Switzerland welfare dependency of immigrants is significantly higher than that of natives. This seems to correlate with the amount of benefits granted under the welfare systems. The risk of serving as "welfare magnets" has caused a number of countries to limit the welfare benefits that new immigrants can claim.

117. The fiscal impact of immigration would evidently depend on the age at which immigrants arrive in the host country. Those who come at working age are likely to make a greater contribution to public finances and social security than those who come in as young children. A study in Germany, for example, shows that someone who immigrates at age 30 will contribute 110,000 euros over his or her lifetime, while one who immigrates before his or her first birthday will create a net burden on public finances of 60,000 euros. Since 78 per cent of immigrants in Germany are of working age, the representative migrant makes a positive net contribution of some 50,000 euros in his or her lifetime. Immigration therefore helps Germany to close the gap between expected tax revenues and government consumption and debt servicing. In the United States some studies have concluded that immigrants make more use of welfare in terms of public assistance and free medical care than do natives. This is mainly because immigrants are on average less educated and poorer than natives. Other studies find that low-income immigrants are less likely to claim welfare than low-income natives. ${ }^{39}$ Taking the longer view of immigration, a study for the United States National Academy of Sciences has concluded that although immigrants will in the early years add to costs, particularly for education, eventually each immigrant, with his or her descendants paying taxes, will make a net positive contribution to the national budget of US\$80,000. ${ }^{40}$

118. As regards undocumented migrants, they are often so preoccupied with concealing their existence that they are unlikely to claim welfare. Employers who treat them as legal immigrants on the basis of fake social security cards will be paying social security contributions to the Government. These funds accumulate in a "suspense file" for contributions that cannot be matched to legally recorded names and will not therefore generate benefits. In the United States during the period 1990-98 these funds amounted to more than US\$20 billion. Many undocumented immigrants pay taxes through automatic deductions, and even some of those paid in cash voluntarily pay taxes to prove their residence in the country in the case of a future amnesty. In some countries, the tax and social security authorities are legally prevented from sharing information with the immigration authorities. ${ }^{41}$

\footnotetext{
${ }^{38}$ In the United States there has been a rise in welfare use by the immigrant population; it would seem that the longer immigrants stay the more likely it is that they will use welfare. See G. Borjas: Heaven's door: Immigration policy and the American economy (Princeton, N.J., Princeton University Press, 1999).

39 M. Fix and J. Passel: Trends in noncitizens' and citizens' use of public benefits following welfare reform: 1994-97 (Urban Institute, Washington, DC, 1999).

40 J. Smith and B. Edmonston: The New Americans: Economic, demographic and fiscal effects of immigration (Washington, DC, National Academy Press, 1997).

${ }^{41}$ G. Hanson et al., op. cit., p. 248.
} 
119. Other countries of immigration have also shown that immigrants are paying their way. In Australia, for example, a study in 2000 found that for the younger age groups in particular immigrants were less likely to be receiving welfare payments than those born in Australia. ${ }^{42}$ Across the European Union the fiscal impact is more ambiguous. In a number of countries (Germany, the United Kingdom, Greece, Spain and Portugal) dependency on welfare among immigrants is similar to, and sometimes lower than, that of EU citizens. ${ }^{43}$ In the United Kingdom, for example, one study revealed that the foreign-born population contributed around 10 per cent more to government revenue than they took in benefits, and concluded that were it not for the immigrant population, either public services would have to be cut or income taxes would need to increase. The British Home Office carried out a more detailed analysis of the fiscal impact of the migrant population in the United Kingdom and estimated that in 1999/2000, migrants in the United Kingdom contributed $£ 31.2$ billion in taxes while they consumed $£ 28.8$ billion in benefits and state services - a net fiscal contribution of approximately $£ 2.5$ billion after rounding." 44

\section{(c) Social consequences of immigration}

120. Migration has a profound impact on host societies beyond quantifiable economic consequences, which to a large extent explains the controversies that surround migration policy. Migration changes society and its institutions. Because its composition rarely mirrors that of the receiving society, with the large majority having lower education and experiencing greater disadvantages in the labour market, it tends to lead to changes in social stratification. ${ }^{45}$ The entry of new migrants, especially those from very different ethnic origins, usually leads to fragmentation of the working classes and segmentation of the labour market. The growth in numbers of migrants in an irregular situation has only exacerbated this trend. Migrants, however, have experienced markedly different rates of social mobility in different countries, suggesting that integration policies, as well as social and economic conditions, determine the final consequences of migration.

121. Immigration alters a country's sense of national identity, a development that may be by and large welcomed - as for example in Canada - but not as well accepted in Germany or France. Regardless of the differences in attitudes, it is evident that the living and working together of people coming from different origins and possessing different social values and standards inevitably transform societies. This is nowhere more evident than in the large cosmopolitan centres like New York, London, Cairo, Bangkok, and even Moscow and Tokyo. Fortunately, increasing diversity has not led to a breakdown of social cohesion in many countries and the large cosmopolitan centres appear to have benefited hugely from the entry of energetic migrants with new ideas and different outlooks.

\footnotetext{
${ }^{42}$ B. Birrell and J. Jupp: Welfare recipient patterns among migrants (Canberra, Australian Department of Immigration and Multicultural Affairs, 2000).

43 Brücker et al., op. cit., p. 74.

${ }^{44}$ C. Gott and K. Johnston: The migrant population in the UK: Fiscal effects (London, RDS Occasional Paper No. 77,2002$)$

45 See S. Castles and M. Miller: The Age of Migration (New York, Palgrave Macmillan, 1998, paperback edition 2003).
} 


\section{Box 2.1}

\section{Impact of migration on social and demographic structure of the population in Russia}

Today many Russian regions find themselves in a deep demographic crisis. Under these conditions, migration plays the role of a "shock absorber" in the process of the reduction of the population. For example, in 1992, migration growth compensated by 85 per cent for the natural loss of the population; in 1994, by 93 per cent; in 1996 and 1997, by some 50 per cent; and in 1999 and 2000 by some 20 per cent. In the course of 19922000 , the net migration growth in Russia amounted to some 3.6 million persons, which made it possible to slow down the rates of depopulation affecting many regions.

Many surveys show that these persons are, as a rule, migrants of active working age with an adequate educational level. For example, in 1998, the share of the persons of active working age among external migrants amounted to 63.8 per cent, and among the permanent Russian population, 58 per cent. Among migrants, more than 15 per cent of the newcomers had higher and undergraduate education; 31 per cent, secondary and specialized secondary education, the same indicators among the permanent population being 13 per cent and 24 per cent respectively. In fact, immigrants to Russia are already well-trained specialists who can be used in various branches of the national economy without additional budget expenditures.

The experience of Stavropol Territory is quite significant. According to the results of our studies, the migration flow includes basically highly qualified persons. In Stavropol Territory, 17 per cent of the migrants have higher education and some 30 per cent specialized secondary education. Moreover, migration here exerts a stabilizing influence on the demographic situation, compensating for the loss of population, as a result of a sharp reduction in birth rates in the region. The flow of forced migrants has saved a number of village schools from closing down. It would be interesting to know that it was migration that slightly increased the number of marriages.

As is known, prevailing evaluations of the after-effects of migration flows in various sources include pressures on labour markets, deterioration of the socio-economic situation and increased criminality. At the same time, from the point of view of the demographic situation, for many regions of Russia migration today is an unquestionably favourable phenomenon since it plays the role of a "shock absorber" of the negative demographic consequences of reduced natural population growth.

It should be admitted that migration in Russia has partially impeded the process of further ageing of the population and slightly improved the educational and occupational composition of the population.

Source: S.V. Ryazantsev: External labour migration in Russia, ILO International Migration Programme, Geneva, forthcoming.

\section{Case study of ageing and migration in Europe}

Europe is ageing rapidly. In 2000 , the United Nations Population Division published a report," which stated that for the present 15 States of the EU, about 47 million migrants would be needed to maintain the overall size of the population until 2050; about 79 million migrants would be needed to maintain a constant size of the 15-64 years age group; and about 674 million would be needed to maintain a constant old-age dependency ratio. This conclusion perturbed many people in Europe and prompted some to speculate as to what extent ageing would reduce the standard of living and the social security of Europeans.

In order to ascertain the potential immigration needs of the current EU countries, the ILO performed a combined demographic and economic analysis to assess how ageing would reduce the standard of living (as measured by per capita GDP) under different assumptions. If the labour force participation rates remain constant, an ever-increasing share of the population will be inactive as a result of old age; an ever-decreasing share of the population will have to produce the goods and services needed, and that active 
group will itself become older and older. These developments will also affect long-term economic growth rates.

For the purpose of the exercise the GDP per capita and hence the average per capita consumption level is targeted to increase in real terms by about 3 per cent per annum. The historical trend in labour productivity is assumed to continue (increase by 2.5 per cent a year). The labour force participation rates for women are assumed to increase by about 1 per cent per year for the next 25 years until they reach a level only 5 percentage points less than that of males. There is no general increase in effective retirement age; and a rate of "unavoidable" frictional unemployment is assumed to be 2.5 per cent for the whole period.

If the EU-15 as a whole does not take any corrective measures (i.e. if there is no change in the labour force participation and no migration of additional workers), the analysis using a simulation model predicts a substantial labour shortage of about 38 million workers by 2050 , assuming a rise in labour productivity of 2.5 per cent. If productivity only rises by 2 per cent a year, the shortage grows to 88 million workers. The effect on the "gap between the targeted standard of living and the one that is possible" would be substantial. Per capita GDP would be only 78 per cent of the expected level by 2050 .

What would happen now if Europe were to take corrective action through the import of labour rather than changing its labour force participation behaviour, inter alia, through later retirement age, longer working hours, or switching to more productive work patterns? Workers, of course, will not come alone; they will come with their families and the total population will spiral upwards. The reason is that, in closing the employment gap, the migrant workers and their families will push up overall consumption levels - and hence the necessary GDP level - so that the structural labour gap of the native population is further increased and the subsequent year's gaps and replacement needs become bigger than under the original conditions.

The results of the simulation are striking. In an ever-increasing effort to fill the labour gap, the total population of EU-15 would have to approximately double within the next 50 years and the net increase of the population would be about 388 million. This would seem to be a most unlikely scenario. Societies are unlikely to absorb such a massive increase in migrant population. They will make other adjustments.

One clear option for the EU countries is to increase the retirement age from about 60 (de facto) to 65 years. This would mean increasing labour force participation by about 15 per cent. Doing so greatly changes the results. It reduces the needed additional immigrant population to about 112 million over 50 years (figure 2.2).

The changing demographic structure in an ageing society has an obvious impact on the social protection system. Generally expenditure for pensions and health care will increase, while other expenditure items such as child and family benefits will decrease as societies age. In the EU, pension and health expenditure account for about 75 per cent of total social expenditure, with pensions alone accounting for about half. Controlling pension expenditure would thus go a long way towards keeping the overall social expenditure at sustainable levels. To demonstrate the effect it is assumed (see figure 2.3) that EU-15 has increased the retirement age to 65 years and reduced replacement rates of social security pensions to a uniform rate of 40 per cent of the average wage - a rate barely higher than many national relative poverty rates. Old-age pensions of this level are assumed be financed on a pay-asyou-go (PAYG) basis.

Under a "no migration" scenario, it is no surprise that the PAYG contribution rate (cost rate without administrative cost) and the cost measured in GDP shares (the GDP cost ratio) would increase by over 50 per cent over the projection period. Under the migration scenario with higher labour force participation rates and a retirement age of 65 , the cost would increase likewise over the next decades but would be brought back to the present levels once the replacement migration sets in. Figure 2.3 shows this graphically.

The above results indicate broad directions for future policies. It appears that standards of living and the financial stability of nationals could be safeguarded by a careful policy mix. That mix has to find a compromise between accepting lower economic growth (and hence lower growth rates in standards of living), accommodating replacement migration, increasing labour force participation rates and, as a consequence, investing in the increase of productivity of older workers. It is obvious that controlled migration plays a crucial role in the portfolio of policies.

* United Nations Population Division: Replacement migration: Is it a solution to declining and ageing populations? Doc. ESA/P/WP.160 (New York, United Nations, 2000). 
Figure 2.2. Projected total population (EU-15) under status quo and standard migration assumptions with and without the effect of alternative labour force participation rates, in thousands, 2000-50

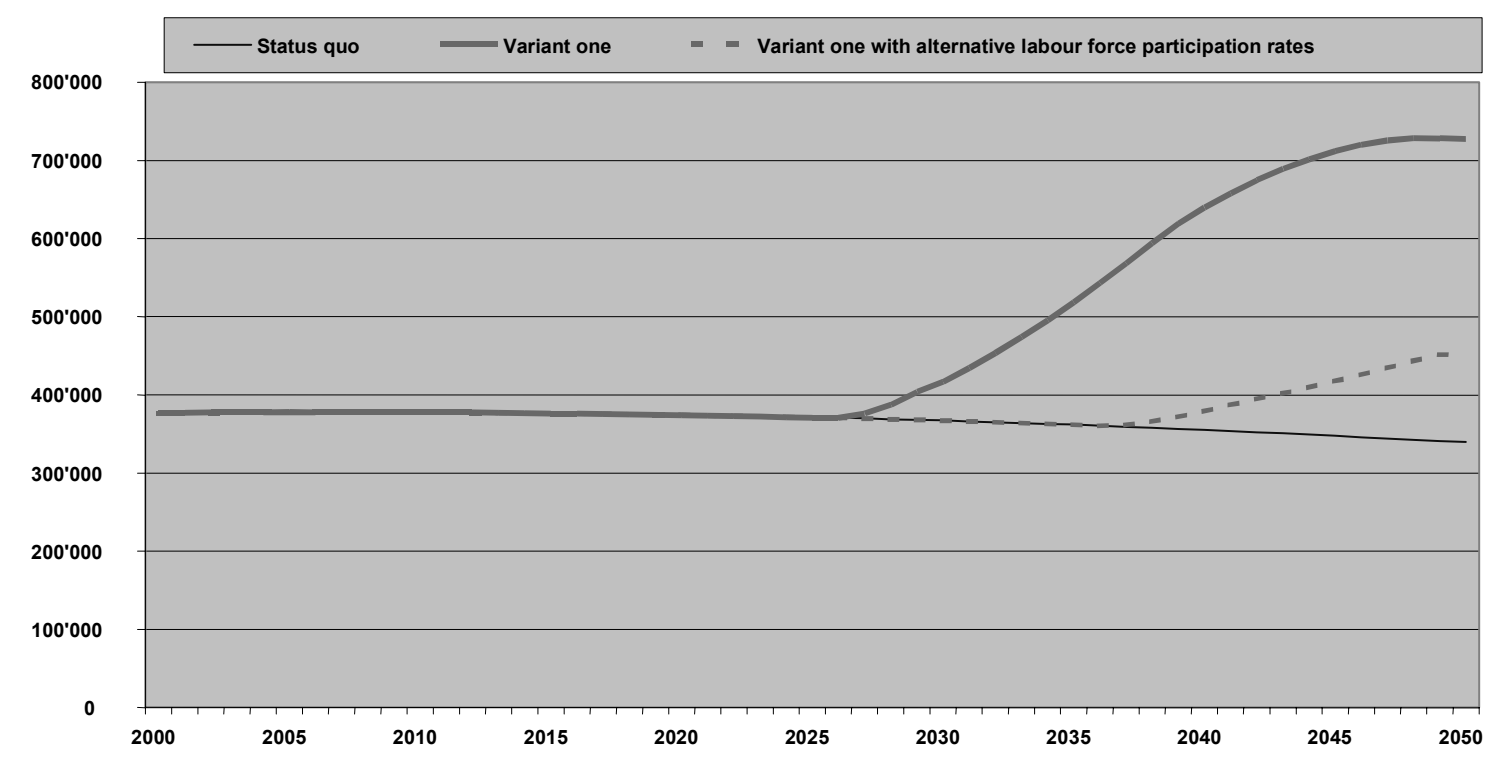

Figure 2.3. Projected PAYG cost ratios and GDP cost ratios of PAYG pension schemes in EU-15, 2000-50

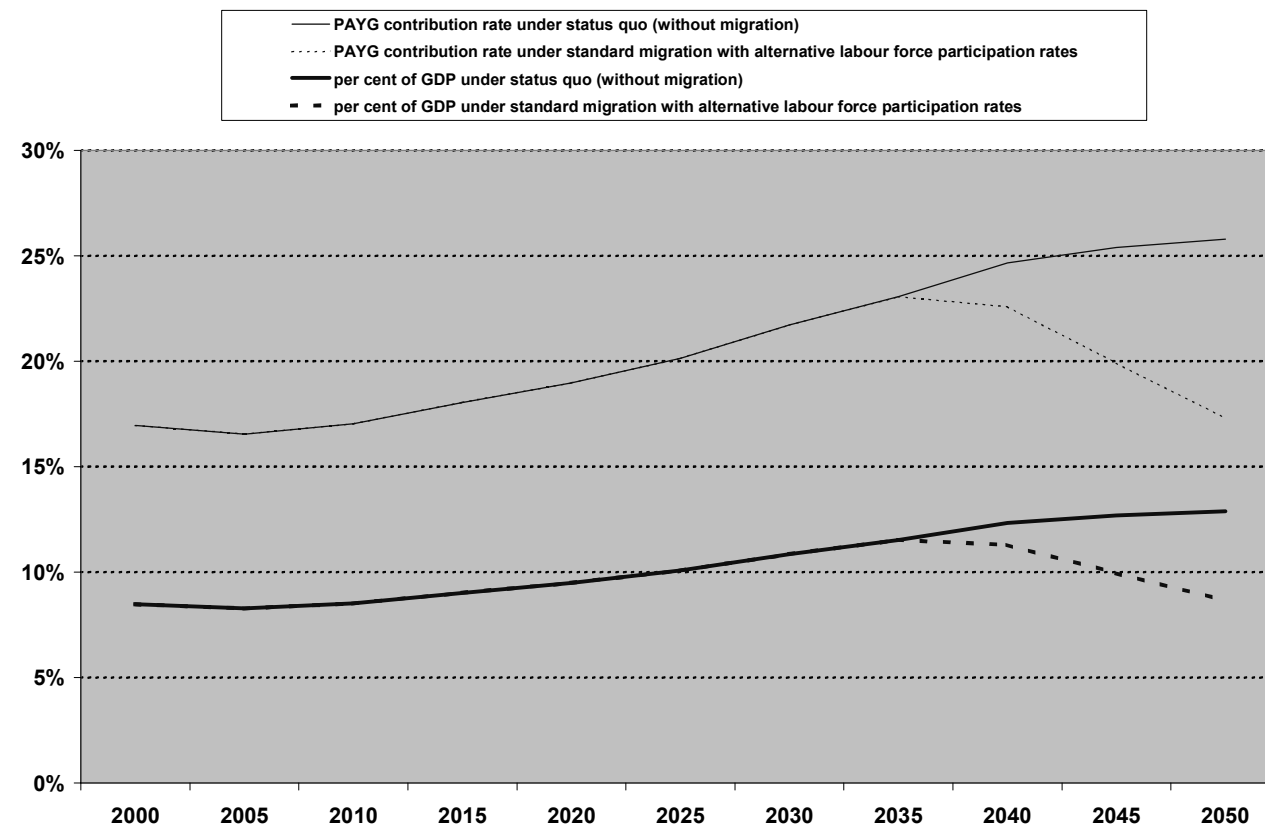




\subsection{Preliminary conclusions}

122. We live in an age of global migration, with more migrants moving in more ways to more countries than ever before. As in the past, this migration is mostly beneficial for the migrants that move, the countries that welcome them, and the countries they leave. The challenge is to manage the migration that is occurring in a way that maximizes benefits for all parties involved.

123. Origin countries have begun to recognize that their nationals abroad can be an important source of finance for development, as their remittances can cover family living expenses as well as investment for job creation. Migrants who return or circulate between sending and receiving countries can also be an important source of new technologies and ideas. When recruitment, remittances, and returns come together in a virtuous circle, as in the Indian IT sector, the result can be an important new export industry that also benefits those who did not migrate.

124. The ambition and drive that motivates people to migrate generally helps migrants in many countries to find jobs, work hard, and benefit both themselves and host country nationals. In most cases, migrants have only slight negative effects on the wages of nationals, and they usually pay more in taxes than they receive in tax-supported services. There is also little evidence that migration leads to much displacement of nationals in employment.

125. Finally, demographic trends in some regions suggest that immigration will be an important component of a long-term solution to the anticipated problems raised by ageing. Along with raising labour productivity and increasing labour force participation - especially among older workers - countries will need to consider more immigration if a decline in levels of welfare is to be avoided. Promoting consensus on these long-term issues is clearly the task of responsible political leadership, since immigration always imposes social adaptation which must be supported by appropriate public policy. 


\section{Chapter 3}

\section{Conditions of work and treatment of migrant workers}

\subsection{Introductory remarks}

126. Analysis in preceding chapters suggests that international migration for employment is likely to increase in the future, with potential benefits for countries of origin and destination and for the migrants themselves. A major precondition for harnessing these potential benefits is an effort to ensure decent working conditions for migrant workers. For many, migrating for work may be a rewarding and positive experience, but for an unacceptably large proportion of migrants, working conditions are abusive and exploitative, and may be characterized by forced labour, low wages, poor working environment, a virtual absence of social protection, the denial of freedom of association and union rights, discrimination and xenophobia, as well as social exclusion, all of which rob workers of the potential benefits of working in another country. ${ }^{1}$ The development of labour institutions for the protection of migrant workers has lagged behind the growth of migration.

127. This chapter reviews working conditions for international migrants and the factors that determine these conditions, with a special focus on more vulnerable groups of lowand semi-skilled women and men migrant workers who need greater protection. ${ }^{2}$ Information has been gathered from several different sources, including the International Labour Migration Survey (ILM Survey). ${ }^{3}$ The analysis considers specific vulnerable groups, including domestic workers and migrant workers in an irregular status and employment sectors where migrant workers are predominant. Integration of migrants in host societies and health issues are discussed next, followed by conclusions. ${ }^{4}$

128. While the report overall focuses mostly on positive aspects of international labour migration, the present chapter considers problem areas and reviews significant, practical initiatives at different levels to address them. The way these concerns are reflected and addressed in international standards is reviewed in the following chapter.

\footnotetext{
${ }^{1}$ ILO: Summary of conclusions, Report of the Regional Tripartite Meeting on Challenges to Labour Migration Policy and Management in Asia, 30 June-2 July 2003, Bangkok; ILO: Summary report and conclusions, Tripartite Forum on Labour Migration in Southern Africa, Pretoria, South Africa, 26-29 November 2002.

2 This report does not deal with the working conditions and treatment of internal migrant workers, although their situation has close parallels with that of international migrant workers, especially in large countries like India or China.

${ }^{3}$ For all references to the results of the ILM Survey see Annex I.

${ }^{4}$ Social security issues are discussed in Ch. 4.
} 


\subsection{Scope and criteria of working conditions}

129. Concerns relating to working conditions and the treatment of migrant workers have been articulated in numerous international labour standards developed by the ILO, as well as in international instruments developed by the United Nations. These cover issues such as remuneration, hours of work, holidays with pay, minimum age for employment, occupational safety and health measures, social security measures and welfare facilities and benefits provided in connection with employment, and security of employment. A fundamental principle is that of equality of treatment: Article 12 of the Migrant Workers (Supplementary Provisions) Convention, 1975 (No. 143), urges States to "guarantee equality of treatment, with regard to working conditions, for all migrant workers who perform the same activity whatever might be the particular conditions of their employment", and Article 25, paragraph 1, of the International Convention on the Protection of the Rights of All Migrant Workers and Members of their Families also calls for equal treatment: "Migrant workers shall enjoy treatment not less favourable than that which applies to nationals of the State of employment" in respect of remuneration and other conditions of work and terms of employment.

130. Migrant workers' issues should be seen in the context of the ILO's decent work framework because conditions of work determine the quality of employment. Decent jobs should mean fair and acceptable conditions of work. The Director-General's report to the International Labour Conference in $2001^{5}$ identified decent work deficits for workers in four categories: employment, rights at work, social protection, and social dialogue.

\subsection{Factors affecting conditions of work}

131. Disparities in working conditions and treatment in countries of destination exist at two levels: (a) between migrant workers themselves; and (b) between migrant workers and national workers. While some disparities can be explained by factors such as differences in migration status, skill profiles, or the nature of jobs and employment sectors, some are attributable to deliberate differential treatment. A brief discussion of this follows.

\section{(a) Evidence of disparities}

132. Differences in unemployment rates are a clear indicator of the disadvantageous position of migrants in the labour market: in the period 2000-01, migrant men and women in OECD countries had unemployment rates that averaged almost twice those of non-migrant men and women. In Denmark and Switzerland, the migrant unemployment rate for men was over three times the corresponding non-migrant rate, and unemployment rates for migrant women were over 20 per cent in Finland, France, and Italy ${ }^{6}$ (see table 3.1 ).

\footnotetext{
${ }^{5}$ ILO: Reducing the decent work deficit - A global challenge, Report of the Director-General, Part I(A), International Labour Conference, 89th Session, Geneva, 2001.

${ }^{6}$ OECD: Trends in international migration: SOPEMI annual report, 2002 edition, Paris, 2003, tables 1.13 and 1.14 .
} 
Table 3.1. Migrant and non-migrant workers in selected OECD countries, 1995 and 2000

\begin{tabular}{|c|c|c|c|c|c|c|c|c|c|c|}
\hline \multirow[t]{2}{*}{ Country } & \multicolumn{2}{|c|}{$\begin{array}{l}\text { Foreign workers } \\
\left(\${ }^{\prime} 000 \text { s) }\right.\end{array}$} & \multicolumn{2}{|c|}{$\begin{array}{l}\text { Total labour } \\
\text { force }(\%)\end{array}$} & \multicolumn{4}{|c|}{ Unemployment rate 2000-01 (\%) } & \multicolumn{2}{|c|}{$\begin{array}{l}\text { Unemployment } \\
\text { ratios }\end{array}$} \\
\hline & 1995 & 2000 & 1995 & 2000 & $\begin{array}{l}\text { Nationals } \\
\text { (male) }\end{array}$ & $\begin{array}{l}\text { Foreigners } \\
\text { (male) }\end{array}$ & $\begin{array}{l}\text { Nationals } \\
\text { (female) }\end{array}$ & $\begin{array}{l}\text { Foreigners } \\
\text { (female) }\end{array}$ & $\begin{array}{l}\text { For./nat. } \\
\text { (male) }\end{array}$ & $\begin{array}{l}\text { For./nat. } \\
\text { (female) }\end{array}$ \\
\hline Austria & 366 & 377 & 9.7 & 9.8 & 3.9 & 8.4 & 3.9 & 8.6 & 2.2 & 2.2 \\
\hline Belgium & 327 & 266 & 7.9 & 8.4 & 4.6 & 14.2 & 7.0 & 16.5 & 3.1 & 2.4 \\
\hline Denmark & 54 & 78 & 0.2 & 2.8 & 3.6 & 12.2 & 4.9 & 7.2 & 3.4 & 1.5 \\
\hline Finland & 18 & 34 & 0.8 & 1.3 & 10.0 & 24.2 & 11.2 & 29.9 & 2.4 & 2.7 \\
\hline France & 1566 & 1571 & 6.3 & 6.1 & 7.1 & 17.1 & 10.7 & 23.9 & 2.4 & 2.2 \\
\hline Germany & 3505 & 3429 & 9.1 & 8.8 & 7.2 & 13.4 & 7.8 & 11.7 & 1.9 & 1.5 \\
\hline Greece & 71 & 163 & 1.7 & 3.8 & 7.2 & 7.6 & 16.2 & 17.6 & 1.1 & 1.1 \\
\hline Ireland & 42 & 60 & 3.0 & 3.5 & 4.1 & 5.1 & 3.8 & 6.2 & 1.2 & 1.6 \\
\hline Italy & 100 & 246 & 0.5 & 1.1 & 8.0 & 7.4 & 13.9 & 21.3 & 0.9 & 1.5 \\
\hline Netherlands & 281 & 298 & 3.9 & 3.7 & 1.9 & 4.7 & 2.9 & 7.0 & 2.5 & 2.4 \\
\hline Norway & 59 & 75 & 2.7 & 3.2 & 3.7 & 5.3 & 3.4 & 4.5 & 1.4 & 1.3 \\
\hline Portugal & 21 & 104 & 0.5 & 2.2 & 3.1 & 8.4 & 5.1 & 9.6 & 2.7 & 1.9 \\
\hline Spain & 121 & 227 & 0.8 & 1.4 & 9.3 & 12.9 & 19.8 & 17.2 & 1.4 & 0.9 \\
\hline Sweden & 186 & 205 & 4.2 & 4.8 & 5.5 & 16.1 & 4.6 & 13.0 & 2.9 & 2.8 \\
\hline Switzerland & 729 & 717 & 18.6 & 18.3 & 1.3 & 4.3 & 2.6 & 6.4 & 3.3 & 2.5 \\
\hline United Kingdom & 1011 & 1220 & 3.6 & 4.2 & 5.5 & 16.1 & 4.4 & 7.9 & 2.9 & 1.8 \\
\hline Australia & 2139 & 2365 & 23.9 & 24.5 & 6.7 & 6.6 & 5.8 & 6.9 & 1.0 & 1.2 \\
\hline Canada & 2839 & & 19.2 & & 10.3 & 9.9 & 9.5 & 11.6 & 1.0 & 1.2 \\
\hline United States & 14083 & 17384 & 10.8 & 12.4 & 4.9 & 4.4 & 4.1 & 5.6 & 0.9 & 1.4 \\
\hline Average & & & 6.7 & 6.7 & 5.7 & 10.4 & 7.5 & 12.2 & 2.0 & 1.8 \\
\hline
\end{tabular}

Note: Foreign workers are non-nationals (Europe) or foreign born (Australia, Canada, United States).

Source: OECD: Trends in international migration: Continuous reporting system on migration: Annual report, 2002 edition (Paris, 2003), compiled from tables I.13 and I.14, pp. 59 and 60.

133. There are also notable differences with regard to employment security. National workers in most host countries can expect some form of protection in the case of loss of employment, such as redundancy payments or unemployment insurance, and perhaps an opportunity for retraining. At the very least, they can look for another job. Migrant workers have in general much less security. Permanent migrants may eventually enjoy labour market advantages similar to nationals, but these are not normally available to temporary workers. Some countries allow temporary migrant workers to seek alternative employment for the duration of their residence permit, but in others, work and residence permits are combined, so that losing a job means loss of the right to live in the country. ${ }^{7}$

\footnotetext{
${ }^{7}$ According to the ILM Survey, 32 member States indicated that migrant workers who lost their employment through no fault of their own were not allowed to stay and seek new employment, while 47 granted migrant workers such rights. Upon regular termination of the contract of temporary migrant workers, 21 member States allowed them to stay and seek other employment while 53 did not. See Annex I.
} 
134. Chapter 2 (section 2.2(a)) highlighted the disparities in wages between migrants and native workers. It was shown that in general the wages of migrants as a group are lower than those for native workers, and that this is partly explained by lower levels of education and skill among migrants, with discriminatory practices also playing a role. In the Middle East, there is a high level of segmentation in the labour market and large wage disparities between national and foreign workers. The relatively low wages of migrant workers seem to be determined by the prevailing labour market conditions in sending countries. ${ }^{8}$ In Asia also, women and men migrant workers generally receive lower wages compared to native workers for the same work. ${ }^{9}$

\section{(b) Reasons for differences in working conditions}

\section{Migration status}

135. While all migrants are workers employed outside their country of birth or citizenship, their status abroad ranges widely: they may be legal migrants with the right to settle and become naturalized, temporary guest workers required to leave when a contract expires, or unauthorized workers liable to arrest and removal at any time. Temporary workers are rarely accorded the same treatment given to permanent workers, as a matter of policy aimed at discouraging settlement. Those migrating under irregular conditions, and persons trafficked or smuggled, normally experience the most unfavourable conditions of work, and often have limited means of seeking redress.

\section{Conditions of recruitment}

136. ILO instruments recommend bilateral agreements as means of regulating labour migration, and they were the norm in the 1950s and 1960s, when public employment services played a significant part in the recruitment of migrants and in ensuring that they left their own countries with contracts setting out wages and working conditions. Today, the international mobility of workers is increasingly in the hands of private fee-charging recruitment agencies which play a crucial role in facilitating migration for employment. ${ }^{10}$ They are also responsible for a number of unethical practices which promote irregular migration and cause immense hardship to actual and potential migrants. Some recruitment agencies send workers for non-existent jobs, some provide false information about jobs, and many charge migrants excessive fees for services. ${ }^{11}$ The sponsorship or "khafeel" system common in the Gulf States has also resulted in labour inflows not matched by actual employer demand, resulting in irregular status for

\footnotetext{
${ }^{8}$ ILO: Migrant workers in Kuwait: A review of the recruitment system in an international context (unpublished report, Geneva, International Migration Programme, 2002); ILO studies on women migrant workers in Bahrain, Lebanon and the United Arab Emirates; K.C. Zachariah et al. (eds.): Kerala's Gulf connection: CDS studies on international labour migration from Kerala state in India (Ulloor, Kerala, India, Centre for Development Studies, 2002).

9 P. Wickramasekara and M. Abella: "Protection of migrant workers in Asia: Issues and policies", in Labour migration in Asia: Trends, challenges and responses in countries of origin (Geneva, International Organization for Migration, 2003, pp. 53-75).

${ }^{10}$ Of the 90 respondents to the ILM Survey, just under half authorized private recruitment agencies to bring in migrant workers, and 23 indicated that private recruitment agencies were entitled to charge fees. The respondents also reported on malpractices in this area, including the offering of non-existent jobs, withholding of information or provision of false information on the nature of jobs and conditions of employment, and the imposition of exorbitant fees. See the summary of replies to the ILM Survey (Annex I) for further details.

${ }^{11}$ Report of the ILO Asian Regional Tripartite Meeting, Bangkok, 2003, op. cit. which notes widespread recruitment malpractices, fraud and abuses in many Asian countries.
} 
the migrants. ${ }^{12}$ Some intermediaries engage in smuggling and trafficking of migrants which are proving difficult to stop. As an ICFTU-APRO report noted: "Employment agencies caught for their malpractices and even illegal work are quite often found escaping any punishment. If at all a punishment is given, the penalty imposed is far less than the crime and damage inflicted on the concerned migrants". ${ }^{13}$

137. Subcontracting of temporary and seasonal workers through labour brokers in many sectors has been at the expense of worker benefits and entitlements such as holidays, bargaining rights and social protection. The manner of recruitment and placement thus has far-reaching consequences for the working conditions and general treatment of migrant workers. Some may be forced to endure situations of virtual debt-bondage or near-slavery to pay off debts owed to recruiters and traffickers.

\section{Sector of employment or occupation}

138. Migrant workers are concentrated in the labour markets that are sometimes characterized as the "bargain basement" of globalization. Most are employed in low-skill services, agriculture and labour-intensive manufacturing in which employers are small enterprises that are basically "price-takers" - that is, they have no influence on the prices of their products or services. With intensifying competition with suppliers from other parts of the world, employers in these sectors seek to maintain their small margins by squeezing workers' wages. Garment manufacturing, for example, is one industry that is at the "squeezed" end of the "buyer-driven chain" and one that relies heavily on migrant labour.

139. The more highly skilled workers migrate, mostly through regular channels, into formal sector jobs with good conditions of work, although there are exceptions. However, the great majority of migrant workers are in low-skilled occupations, usually in jobs requiring long or irregular hours of work or subject to seasonal lay-offs - jobs normally shunned by national workers. These issues are discussed below in section 3.4.

\section{Growth of the informal sector in developed economies ${ }^{14}$}

140. Changing economic and demographic trends are combining to increase the effective demand for foreign labour in many industrialized countries. Ageing populations, older workforces and fewer entries into labour markets combine with the persistence of dual labour markets to expand the number of precarious jobs often filled by migrants. Many small and medium-sized companies and labour-intensive sectors that find it hard to relocate abroad try instead to hold down labour costs by hiring migrants, so that the demand for foreign labour reflects the long-term trend of informalizing or downgrading low skilled and poorly paid jobs. Migrants in irregular status are often preferred since they are willing to work for lower wages, for short periods during production peaks, and to accept physically demanding and hazardous jobs. ${ }^{15}$ The

${ }^{12}$ M. Ruhs: Temporary foreign worker programmes: Policies, adverse consequences and the need to make them work (Geneva, ILO, Social Protection Sector, Perspectives on Labour Migration, No. 6, 2003).

13 ICFTU/APRO: Migration issues concern trade unions: Background proceedings, action plan and conclusions, Regional Consultation on Developing a Cooperating Mechanism for Promoting and Protecting the Rights of Migrant Workers, Jakarta, 19-21 March 2003.

14 P.A. Taran: Globalization, migration and the rule of law: Roles and challenges for international organizations, Paper presented at the Workshop "Managing the employment of foreign workers: What role for international standards and institutions?", Eighth International Metropolis Conference, Vienna, 15-18 September 2003.

15 P. Stalker: Workers without frontiers: The impact of globalization on international migration (Geneva, ILO, 2002). 
resulting demand for migrant workers provides a significant impetus to labour flows and encourages the use of undocumented migrants, at the expense of formal protections of workplace safety, health, minimum wage and other standards.

\section{Lack of freedom of association and bargaining rights}

141. The right to organize and to form trade unions is of fundamental importance in the world of work and is of particular importance to migrant workers. Representation and a voice at work are important means by which migrant workers can secure other labour rights and improve their working conditions, and may be a crucial avenue by which temporary and migrant workers in irregular status can assert their rights. While these rights may be upheld and freely exercised in many countries, migrant workers' rights to organize and protect their interests are frequently violated. Permanent migrant workers are more often able to exercise these rights than temporary workers or, in particular, migrant workers in irregular status, ${ }^{16}$ but national legal restrictions based on nationality may make it more difficult for migrant workers to act as trade union officials, to be active as members of an organization, or to form their own unions. Workers in an irregular situation are generally not in a position to demand any rights, given their precarious position. The ILO Workers' Consultation on Migrant Workers in December 2003 reiterated that organizing migrants was a paramount task for trade unions, and that legislation preventing migrants from joining unions should be repealed, as should provisions in trade union statutes and rules which contain obstacles to the membership of migrants. ${ }^{17}$

\section{Discrimination and xenophobia in the workplace}

142. While it may be understandable why migrants suffer some forms of labour market disadvantages upon entry as a result of language and other handicaps, some disadvantages seem to be systemic, a consequence of policy (or the lack of one), or of discrimination. Migrant workers are frequently subjected to unequal treatment and opportunities, as well as discriminatory behaviour, and these are the key reasons why migrant and ethnic minority workers face greater obstacles than the majority population. ${ }^{18}$ With the support of local foundations and research institutions, the ILO used practice tests in comparing the occurrence of discrimination in access to employment, specifically against migrant workers and ethnic workers in some highly advanced countries (Belgium, Denmark, Germany, Italy, the Netherlands, Spain, Switzerland and the United States). These studies showed that more than one-third of tested vacancies for semi-skilled jobs were closed to young, male applicants of migrant or ethnic minority origin. Higher discrimination rates were detected in the services sector than in other sectors, and in small and medium-sized enterprises than in bigger ones. ${ }^{19}$

\footnotetext{
${ }^{16}$ According to the ILM Survey, 14 out of 90 respondents indicated that the right to organize and protect their interests was reserved for nationals. See Annex I for details.

17 Report of the Workers' Consultation on Migrant Workers, organized by the ILO Governing Body's Workers' group and ACTRAV, Nyon, Switzerland, 15 and 16 December 2003; see also ICFTU-APRO, 2003, op. cit.

18 Only a few respondents in the ILM Survey reported on specific legal restrictions on grounds of nationality. See Annex I.

19 R. Zegers de Beijl: Documenting discrimination against migrant workers in the labour market. A comparative study of four European countries (Geneva, ILO, 2000). The country studies can be downloaded from: http://www.ilo.org/migrant/publ/imp-list.htm . See also ILO: General Survey on migrant workers, Report III (Part 1B), International Labour Conference, 87th Session, 1999, paras. 365-368; and Time for equality at work, Global Report under the follow-up to the ILO Declaration on Fundamental Principles and Rights at Work, Report I(B), International Labour Conference, 91st Session, 2003.
} 
143. Temporary (and a fortiori undocumented) migrants may be excluded from wage protection and from social security programmes as a result of stringent residence requirements. In addition, some jobs disproportionately filled by migrants may be excluded from full coverage under wage laws and benefit programmes, for example in agriculture, in free trade zones, and in private households. ${ }^{20}$ Even if migrants are protected by wage laws and covered by benefit programmes on the same basis as nonmigrant workers, they may not enjoy these rights in practice.

144. According to the ILM Survey, national legislation in just under half the countries surveyed provides for protection against discrimination at work for all workers. In about one-third of countries, this right applies only to nationals and regular migrant workers. Equal treatment with regard to wages and the right to a minimum wage is available to all workers in about 40 per cent of cases, and to national and regular migrant workers only in another 40 per cent of cases. ${ }^{21}$ In five cases, national provisions relating to discrimination were said not to cover migrant workers. A number of countries highlighted problems in applying protection to workers in irregular status. While most protections would cover such workers, some States make it obligatory to inform the immigration authorities if the workers concerned attempt to avail themselves of these provisions. With regard to protection against ethnic and racial harassment, irregular workers are also covered in the majority of cases, particularly against sexual discrimination and harassment, although 24 per cent of the respondents indicated that such legislation applies only to nationals and regular migrant workers.

145. Discrimination based on workers' general state of health, or specifically on their HIV status, is another issue that is becoming increasingly important. ${ }^{22}$ In some cases, testing HIV-negative is a condition for entry into a country, in others a condition for employment or extension of work permits.

146. With considerable numbers of non-nationals and members of ethnic minorities living permanently and legally in migrant-receiving countries, the failure to establish or implement effective anti-discrimination measures may contribute to societal disintegration. ${ }^{23}$ Where discrimination is not addressed, violent backlashes against inequality can occur. Economic arguments and the "business case" against discrimination are well documented. They include the fact that employers may be passing over some of the best-qualified candidates for a given job on irrelevant grounds such as nationality or race, that tolerating discrimination may disrupt work teams and lower productivity, and that allegations of discrimination may hurt an employer's reputation and profits.

\footnotetext{
20 J.M. Ramirez-Machado: Domestic work, conditions of work and employment: A legal perspective (Geneva, ILO, 2003).

${ }^{21}$ See Annex I for details.

22 According to the ILM Survey, 21 member States indicated that HIV/AIDS screening was a condition for entry (see Annex I). On the other hand, more than 15 countries have incorporated in their legislation a prohibition of any kind of discrimination based on health status, including HIV-status. They include Colombia, Costa Rica, Ecuador, Finland, France, Italy, Hong Kong (China), New Zealand, Philippines, Portugal, South Africa, Thailand and Zimbabwe. Several member States specifically define disability so as to include individuals infected by HIV/AIDS, e.g. Australia, Canada and the United Kingdom. See ILO: Governing Body document GB.283/2/1, 283rd Session, March 2002, para.26.

23 ibid.
} 
147. The ILO high-level Tripartite Meeting on "Achieving Equality in Employment for Migrant Workers", Geneva, March 2000, examined the findings and implications of ILO discrimination research, developed a framework and inventory of measures and mechanisms to combat discrimination and promote equality of opportunity, identified an initial listing of best practice measures replicable elsewhere, and elaborated a set of recommendations for future follow-up activity. ${ }^{24}$ The ILO Global Report Time for equality of work in 2003 outlined various measures to combat discrimination against all workers, including migrants. The ILO Governing Body at its 288th Session (November 2003) considered key policy interventions to tackle discrimination at work including an action plan proposed by the Office as a follow-up to the Global Report. ${ }^{25}$

148. Research and experience compiled by the ILO, IOM, OHCHR and UNHCR led to a number of recommendations on discrimination and integration which were jointly forwarded to the World Conference Against Racism and Xenophobia in 2001. The ICFTU Plan of Action against racism and xenophobia elaborates a number of good practices to be adopted by the trade union movement. ${ }^{26}$

\subsection{Conditions of work in selected sectors and occupations ${ }^{27}$}

149. Migrant workers tend to be concentrated in certain sectors of the economy that fail to attract native workers because they are characterized by seasonality of production, a large number of small producers in highly competitive global production chains, lowtechnology, and high firm turnover. In order to address the problems of protecting migrant workers, one needs to understand these structural features of sectors employing migrants and apply the policy tools that will be likely to change them (see table 3.2).

\section{(a) Agriculture}

150. About 43 per cent of the world's total labour force of three billion, or some 1.3 billion workers, are employed in agriculture as self-employed farmers, unpaid family workers and hired workers. The number of "wage" or hired workers is estimated at 450 million, 38 per cent of all persons employed in agriculture and equivalent to the entire labour force of the high-income countries. ${ }^{28}$ Women account for over half of all agricultural labour. ${ }^{29}$

\footnotetext{
${ }^{24}$ P.A. Taran, I. McClure and R. Zegers de Beijl: Challenging discrimination in employment: A summary of research and a compendium of measures (Geneva, ILO, 2000).

25 ILO: Governing Body document GB.288/TC/4, 288th Session, Geneva, November 2003.

${ }^{26}$ ICFTU: Trade unions say no to racism and xenophobia, A plan of action for trade unions (Brussels, 2002).

${ }^{27}$ For details, see P. Martin: Migrant wages and working conditions: Comparisons by sector and country, Paper prepared for ILO/MIGRANT, 3 Jan. 2004.

${ }^{28}$ M. Pigott: Decent work in agriculture, Background paper for the International Workers' Symposium on Decent Work in Agriculture, Geneva, 15-18 September 2003 (ILO/ACTRAV, 2003).

${ }^{29}$ ILO: Facts on agriculture, Department of Communication fact sheet, 2003, available online at http://mirror/public/english/bureau/inf/fact/index.htm (accessed 7 Mar. 2004).
} 
Table 3.2. Employment of foreign workers by sector, 2001-02 average (percentage of total foreign employment)

\begin{tabular}{|c|c|c|c|c|c|c|c|c|c|c|}
\hline Country & $\begin{array}{l}\text { Agriculture } \\
\text { and fishing }\end{array}$ & $\begin{array}{l}\text { Mining, } \\
\text { manufac- } \\
\text { turing and } \\
\text { energy }\end{array}$ & $\begin{array}{l}\text { Construc- } \\
\text { tion }\end{array}$ & $\begin{array}{l}\text { Wholesale } \\
\text { and retail } \\
\text { trade }\end{array}$ & $\begin{array}{l}\text { Hotels and } \\
\text { restaurants }\end{array}$ & Education & $\begin{array}{l}\text { Health and } \\
\text { other } \\
\text { community } \\
\text { services }\end{array}$ & $\begin{array}{l}\text { House- } \\
\text { holds }\end{array}$ & $\begin{array}{l}\text { Admin. } \\
\text { and } \\
\text { ETO }\end{array}$ & $\begin{array}{l}\text { Other } \\
\text { services }\end{array}$ \\
\hline Austria & 1.1 & 24.5 & 13.5 & 15.2 & 11.3 & 2.1 & 6.3 & 0.6 & 1.2 & 24.2 \\
\hline Belgium & 0.9 & 21.4 & 9.0 & 16.0 & 7.9 & 4.3 & 8.0 & 0.9 & 8.3 & 23.3 \\
\hline $\begin{array}{l}\text { Czech } \\
\text { Republic }\end{array}$ & 3.5 & 31.5 & 11.0 & 19.5 & 7.2 & 3.1 & 4.9 & & - & 18.2 \\
\hline Finland & - & 15.3 & 7.8 & 14.5 & 11.0 & 10.8 & 11.5 & - & - & 27.2 \\
\hline France & 3.2 & 17.2 & 17.5 & 11.3 & 7.3 & 3.2 & 5.1 & 6.7 & 2.7 & 25.8 \\
\hline Germany & 1.2 & 32.6 & 8.1 & 12.9 & 11.3 & 2.7 & 7.0 & 0.6 & 2.3 & 21.4 \\
\hline Greece & 3.2 & 17.9 & 27.6 & 11.2 & 10.2 & 1.6 & 1.6 & 17.2 & - & 9.2 \\
\hline Ireland & 3.2 & 17.2 & 6.9 & 10.2 & 13.8 & 5.4 & 10.3 & - & - & 30.1 \\
\hline Japan 1 & 0.4 & 61.5 & 2.0 & 9.3 & 1.0 &.. &.. &.. & .. & 26.8 \\
\hline Luxembourg & 0.8 & 10.4 & 16.4 & 14.1 & 8.2 & 2.3 & 6.1 & 3.1 & 8.7 & 29.8 \\
\hline Netherlands & 3.7 & 21.4 & 4.7 & 15.4 & 8.0 & 4.1 & 11.7 &.. & 3.5 & 27.6 \\
\hline Norway & - & 16.1 & 6.1 & 12.5 & 7.3 & 9.5 & 21.3 & - & - & 23.1 \\
\hline Spain & 8.6 & 11.2 & 15.8 & 10.9 & 16.5 & 3.2 & 1.9 & 14.8 & 0.5 & 16.8 \\
\hline Sweden & - & 19.3 & 3.3 & 10.7 & 5.9 & 8.2 & 19.2 & - & 2.8 & 29.6 \\
\hline Switzerland & 0.8 & 22.9 & 10.2 & 17.9 & 6.9 & 5.0 & 11.6 & 1.2 & 2.5 & 21.0 \\
\hline $\begin{array}{l}\text { United } \\
\text { Kingdom }\end{array}$ & - & 12.0 & 4.4 & 12.0 & 11.0 & 7.7 & 14.0 & 1.3 & 4.1 & 33.1 \\
\hline Australia ${ }^{2}$ & 2.0 & 17.5 & 7.3 & 17.0 & 5.5 & 6.2 & 10.3 & 3.2 & 3.5 & 27.3 \\
\hline $\begin{array}{l}\text { Canada } \\
(2001)^{2}\end{array}$ & 1.8 & 19.1 & 4.7 & 14.2 & 7.4 & 5.7 & 9.4 & 0.6 & 3.9 & 33.2 \\
\hline $\begin{array}{l}\text { United } \\
\text { States }^{2}\end{array}$ & 3.2 & 17.2 & 8.2 & 20.1 & 10.3 & 5.7 & 10.6 & 1.5 & 2.2 & 20.9 \\
\hline \multicolumn{11}{|c|}{$\begin{array}{l}\text { Note: The numbers in bold indicate the sectors where foreigners are over-represented (i.e. the share of foreign employment in the sector is larger } \\
\text { than the share of foreign employment in total employment). The sign "-" indicates that the estimate is not statistically significant. }\end{array}$} \\
\hline \multicolumn{11}{|c|}{$\begin{array}{l}1 \text { Data refer to June 2001. The "hotels and restaurants" sector is included in the "wholesale and retail trade" sector. }{ }^{2} \text { Data refer to the foreign-born } \\
\text { population aged } 15+.\end{array}$} \\
\hline
\end{tabular}

151. Agriculture is a special industry: it is the world's largest employer, and economic development is associated with a declining percentage of the workforce employed in food and fibre production. The exodus of rural youth to manufacturing and services in urban centres has raised the demand for migrant workers. Virtually all governments intervene in agriculture by way of subsidies and taxation. Finally, trade in farm goods is affected by trade preferences and restrictions, as well as migration policies. In the rich countries, many of the subsidized specialty crops, including sugar and some fruits and vegetables, employ migrants.

152. Among the developed countries, the United States has the most hired farm workers: some 2.5 million persons are employed for wages at some time during a typical year, most of them for less than six months. About 90 per cent of the migrants who work seasonally on farms producing fruit, vegetable and horticultural (FVH) commodities 
were born abroad. The share of irregular or unauthorized workers among all hired crop workers rose from less than 10 to over 50 per cent during the 1990 s. ${ }^{30}$ Every year, the European Union's agricultural sector employs close to 4.5 million seasonal workers, almost 500,000 of whom come from countries outside the EU-15. ${ }^{31}$ Women workers make up about 40 per cent of the total seasonal agricultural workforce in Germany. ${ }^{32}$

153. Agriculture is one of the three most hazardous industries (the other two are mining and construction). According to ILO estimates, of 335,000 fatal workplace accidents a year worldwide, some 170,000 involve agricultural workers. Millions more of the world's agricultural workers suffer serious injury in workplace accidents involving machinery or are poisoned by pesticides and agrochemicals. In the United States, for example, agricultural workers made up 3 per cent of the workforce but suffered 7.4 per cent of work-related deaths between 1990 and 1995. ${ }^{33}$ They endure excessive working hours and inadequate daily or weekly rest. Migrant workers, especially irregular workers, are particularly vulnerable since they may not have adequate insurance.

154. The agricultural sector is also characterized by a high incidence of child labour including migrant children. The Safety and Health in Agriculture Convention, 2001 (No. 184), specifies 18 years as the minimum age for employment in agriculture in dangerous jobs and 16 years for other farm jobs. Nonetheless, some 80 million 5- to 14year-olds are believed to be employed in agriculture. In some countries, migrant children are employed to produce commodities for export; for example children from Mali and Burkina Faso work in Côte d'Ivoire, which produces about 40 per cent of the world's cocoa.

155. In developing countries, a series of vicious circles have been lowering wages and protection for hired farm workers, leading to rural-urban and international migration. The many causes of these vicious circles include: intensified competition, especially with countries that heavily subsidize their agriculture; domination of agricultural export markets by multinational buyer cartels; privatization that eliminates jobs in farming and farm-related industries; and rising input costs and declining prices for many commodities produced in developing countries, including bananas, cocoa, coffee and sugar. This cost-price squeeze puts downward pressure on farm wages and incomes and increases emigration pressures in agricultural areas.

156. Year-round workers living on plantations generally enjoyed better protection in the past. The switch to seasonal workers supplied by labour contractors in the 1990s put downward pressure on working conditions for all farm workers, including migrants in the countries in which they are a significant part of the hired workforce (for example, Costa Rica, Malaysia and Thailand). A vicious circle arises when efforts are made to regulate contractors: they often hire the most vulnerable workers, are often under extreme competitive pressure to keep wages low, and generally operate without written contracts and in areas with few labour inspectors. Some 55 per cent of union complaints

\footnotetext{
${ }^{30}$ P. Martin, 2004, op. cit.

31 A. Renaut: "Migrants in European agriculture: open season for exploitation", in Trade Union World Briefing (Brussels, ICFTU), No. 7, Dec. Available online at http://www.icftu.org/www/pdf/briefing_migrantsE.pdf (accessed 7 Mar. 2004).

32 ibid.

33 V. Forastieri: "The ILO Programme on Safety and Health in Agriculture: The challenge for the new century Providing occupational safety and health services to workers in agriculture", in Labour Education, 2000/1-2 (Geneva, ILO), Nos. 118/119.
} 
to the ILO in the 1990s alleging violations of core ILO standards were from the Americas, and many were directed at governments that had assisted, for example, banana plantations seeking to replace year-round workers. ${ }^{34} \mathrm{~A}$ recent publication summarizes the situation as follows:

Poverty wages, atrocious working conditions and downward pressure on the terms of collective agreements negotiated by the unions are all part of the immigrant workers' fate. They embody the whole decent work deficit in agriculture. ${ }^{35}$

157. In Germany, the agriculture and construction union IG Bau has expressed grave concern at the growing trend of permanent jobs being replaced by temporary contracts, particularly in tree nurseries and horticulture. Migrant agricultural workers are often recruited in a very informal manner, often through an intermediary or labour contractor. ${ }^{36}$ According to the British Trades Union Congress, many seasonal workers end up signing contracts that include very high charges for transportation, housing and other services, so that their earnings are often far less than expected. ${ }^{37}$

158. A Council of Europe report noted that reliance on migrant labour has become a characteristic feature of Mediterranean agriculture, especially for seasonal activities, and that the work of many of these migrants is undeclared, as a result of which they have no right to receive minimum wages or make social security contributions and are often subjected to abuse and exploitation. ${ }^{38}$ Abuses of migrants include making false promises concerning wages and working condition during recruitment, high or unexpected charges for transportation, housing and meals, and unauthorized deductions from wages or failure to forward taxes to government authorities.

159. Contractors usually compete with each other on cost, and some agree to supply workers at such low costs that they end up violating minimum wage and tax laws. In the United States, for example, contractors charge an overhead commission of at least 25 to 35 per cent, yet some contractors offer to bring crews to farms for lower overheads, which suggests that they may actually be cheating the workers of wages or the government of payroll taxes. ${ }^{39}$ It is estimated that one-third of workers' wages may be lost as a result. ${ }^{40}$

160. A recent ILO study on decent work in agriculture succinctly summed up the situation:

Deficits in social protection for waged agricultural workers are further exacerbated through the practice of labour contracting, where abusive systems are contributing to the erosion of rights and protection. The system of labour contracting in all its forms (both national and

\footnotetext{
${ }^{34}$ M.L. Pigott, op. cit.

${ }^{35}$ M. Pigott and L. Demaret: "They feed the world, but their children go hungry", in Focus on Trade, No. 95, Nov. 2003, available online at http://www.focusweb.org/publicatons/Fot2003/Fot95.htm (accessed 10 Mar. 2004).

36 A. Renaut, "Migrants in European agriculture ...”, op. cit.

${ }^{37}$ N. Clark: Overworked, underpaid, over here: Migrant workers in Britain, available online at the Trades Union Congress site http://www.tuc.org.uk/international/tuc-6878-f0.cfm (accessed 7 Mar. 2004).

${ }^{38}$ Council of Europe, Committee on Migration, Refugees and Demography: Migrants in irregular employment in the agricultural sector of southern European countries, doc. 9883, 18 July 2003.

39 Many farm organizations survey members and contractors to determine average overheads or commissions, so contractors are rarely able to overcharge farmers.

40 P. Martin, op. cit., 2004.
} 
transnational) now appears to be a central component in labour market institutions in all parts of the world, and underlies many of the decent work deficits identified throughout the paper. ${ }^{41}$

161. With less than 10 per cent of the world's hired farm workers represented by unions, and unions finding it very hard to organize the fast-growing female segment of the seasonal farm workforce brought to farms by contractors, workers' organizations are often weak or non-existent among farm workers. The worker organizations that do exist are often on the defensive, fighting to retain the wages and benefits they have won as state-owned or foreign-owned plantations are restructured. Migrant workers may receive the lowest priority in the process. These factors mean that farm workers often have no collective bargaining rights; they have inadequate income in relation to basic needs, no social protection from unemployment, sickness or injury, and have no voice to further their interests.

162. Nevertheless, trade unions have established a number of good practices with regard to the protection of migrant workers in agriculture. The ICFTU lists a number of good practices for trade unions, including information centres set up with the cooperation of unions in receiving countries. ${ }^{42}$

163. Experience suggests a number of steps that should be taken to reduce the incidence and severity of migrant abuses. The starting point is to identify employers of migrants, which most countries do via a registration or licensing system. Perhaps the most promising way to better regulate contractors who hire mostly migrants may be joint liability and seizure laws, under which the beneficiary of the migrants' labour assumes joint liability with the contractor for paying wages and abiding by labour laws. In most cases, the beneficiary of the work done by workers hired through contractors is the most stable entity in the business relationship, and the rationale for joint liability is that the beneficiaries of contractor-migrant labour will more carefully check the contractors they use if they are liable for violations committed by those contractors. ${ }^{43}$

164. Through trade unions and consumer group pressure, retailers could be made responsible for working conditions since it is they, and not the farm producers, who receive the largest share of retail food spending. The European agricultural workers' unions have urged the promotion of "virtuous recruitment formulas", like those of employers' groups in France. ${ }^{44}$ The Parliamentary Assembly of the Council of Europe, in its Recommendation on migrants in irregular employment in the agricultural sector of southern European countries, ${ }^{45}$ called on member States to establish an effective system of migration management for labour in agriculture, including fair and viable channels for the recruitment of seasonal migrant workers, work permits which give full access to social security and other rights, and appropriate legal frameworks to sanction employers

\footnotetext{
${ }^{41}$ ILO: Decent work in agriculture, Synopsis of the Background paper (IWSDWA/2003) for the International Workers' Symposium on Decent Work in Agriculture, Geneva, 15-18 September 2003.

42 A. Renaut, op. cit.

43 In the United States, courts have established a series of indicators of joint liability that include whether or not the business operator who hired the contractor has any control over the workers brought to the business by the contractor.

${ }^{44}$ Cited in A. Renaut, op. cit.

${ }^{45}$ Council of Europe, Parliamentary Assembly Recommendation 1618 on migrants in irregular employment in the agricultural sector of southern European countries, adopted by the Standing Committee on 8 Sep. 2003, available online at http://assembly.coe.int/Documents/AdoptedText/TA03/EREC1618.htm (accessed 7 Mar. 2004).
} 
of clandestine workers in agriculture and their recruiters, and called for ratification of the International Convention on the Protection of the Rights of All Migrant Workers and their Families.

165. Finally, educating migrants about their rights can help to limit abuses at the hands of employers. There are several ways of educating migrants, including in their country of origin before departure and by having their country's representatives visit them at work abroad, as Mexican representatives visit Mexican farm workers employed on Canadian farms. Trade unions can play a unique role in monitoring conditions for migrant workers, providing education for workers and seeking redress when abuses are found. However, their right to enter workplaces with migrants is not always respected. NGOs dealing with migrant workers' issues may face similar obstacles.

\section{(b) Construction}

166. Construction is a large, labour-intensive industry. Total global employment in the construction sector in 1999 was estimated to be about 112 million, including 29 million in more developed countries and 82 million in less developed countries. ${ }^{46}$ The construction industry has a long tradition of employing migrant labour from lower-wage economies. Migrant labour is important in the countries of the Arabian Gulf, which have small populations and large construction programmes financed by oil. Malaysia and Singapore both rely heavily on foreign construction workers. Israel has replaced Palestinian construction workers with workers from countries such as the Philippines, Thailand, China and Romania. Many of the construction workers in Moscow and its environs come from the Caucasus and the Central Asian republics. A tripartite meeting convened by the ILO in Geneva in March 1996 concluded that countries will continue to rely on foreign workers to fill jobs in construction. ${ }^{47}$

167. Construction remains unique in several respects. It is project-by-project based, with the production site constantly moving; demand is cyclical or has a "boom-bust" quality; and governments often begin public construction projects during recessions to create jobs. The industry is fragmented, with mostly small firms operating only in local markets because of their knowledge of building codes, workers and customers. As the ILO puts it: "It is probably better to regard construction not as an industry, but as a loose agglomeration of agents and activities which can be unpackaged and packaged in different ways." 48

168. Employment relations in construction are unique. ${ }^{49}$ Workers move from project to project, and on any particular building site, there are usually multiple small employers whose activities need to be coordinated so that buildings are constructed in the correct manner and to ensure quality control. The construction workforce includes those with significant skills, such as carpenters and electricians, as well as unskilled labourers, with

\footnotetext{
${ }^{46}$ ILO: The construction industry in the twenty-first century: Its image, employment prospects and skill requirements, report for discussion at the Tripartite Meeting on the Construction Industry in the Twenty-first Century, Geneva, Sectoral Activities Department, 2001, table 1.1.

47 ILO: Note on the Proceedings, Tripartite Meeting on Social and Labour Issues Concerning Migrant Workers in the Construction Industry, Geneva, 4-6 March 1996.

48 "Defining construction", http://www.ilo.org/public/english/dialogue/sector/sectors/constr.htm (accessed 8 Mar. 2004).

49 ILO: The scope of the employment relationship, Report V, International Labour Conference, 91st Session, Geneva, 2003, box 3 ("Construction industry: Dependent and independent workers").
} 
the skilled workers often providing on-the-job training to the unskilled. Many subcontractors on construction sites have limited capital and engage in labour-intensive tasks.

169. Construction used to be an industry that offered above-average wages to compensate for arduous and dangerous work, with relatively large employers making considerable investments in their relatively highly skilled workers and taking responsibility for training replacements. It has also, historically, been an industry with relatively high levels of unionization, at least in the developed countries. The entire industry is, however, undergoing a profound transformation. This is due to the surge in subcontracting and a high level of privatization. ${ }^{50}$ These trends have grown to such proportions that some "builders" see their job solely as managing subcontractors who provide the labour and materials to build a project. Today, casual and temporary employment with firms employing fewer than 20 workers and self-employment have become the rule. In some cases, vertically integrated construction firms have become merely managers who allow subcontractors to compete against one another to supply workers for their projects. ${ }^{51}$

170. As a result, work in construction has become increasingly temporary and insecure, and workers' protection (where it existed at all) has been eroded. The report of the Workers' Consultation notes: "Deregulation has also led to a race to the bottom making jobs in sectors like construction unattractive and underpaid for nationals and calling on foreign labour to fill those gaps, including through irregular migration channels". 52 According to a recent ILO report, the increased employment of labour through subcontractors has also had a profound effect on safety and health at the workplace and has undermined collective bargaining and training provision. ${ }^{53}$

171. The same report states that in much of the world, work in construction is not regarded as "decent work". It is in fact one of the most dangerous sectors, with two to four times the average frequency of fatal accidents. Because of high rates of injury, frequent lay-offs and substandard housing, young people tend to shun construction jobs, setting in motion a vicious circle in which foreigners without adequate protection and training increase their share of the labour force. ${ }^{54}$

172. The current trends towards subcontracting and privatization in the construction industry appear to be irreversible, and it has become important to find ways to make employers, unions, and governments cooperate to ensure that migrant workers employed by subcontractors do not become a disadvantaged and isolated labour force whose vulnerability is used as means of pulling down wages and conditions in the entire

\footnotetext{
${ }^{50}$ Governments undertaking construction projects are often under an obligation to pay prevailing or union wages on projects.

51 ILO: Note on the Proceedings, Tripartite Meeting on the Construction Industry in the Twenty-first Century: Its Image, Employment Prospects and Skills Requirements, Sectoral Activities Programme, Geneva, 10-14 December 2001, p. 24.

52 ILO: Report of the Workers' Consultation on Migrant Workers, op. cit.

53 ILO: The construction industry in the twenty-first century, op. cit.

54 See, for example, A. Abdul-Aziz: "Bangladeshi migrant workers in Malaysia's construction sector", in AsiaPacific Population Journal, Vol. 16, No. 1, Mar. 2001.
} 
industry, and to prevent a race to the bottom that puts construction among the "worst occupations". ${ }^{55}$

\section{(c) Manufacturing: Sweatshops and migrant workers}

173. Globalization has liberalized international capital mobility and the relocation and outsourcing of production. In this process, jobs in manufacturing are created for workers in sending countries, thereby reducing pressures for migration. At the same time, there has been an international outcry regarding the conditions of work in some of the clandestine workplaces - described as "sweatshops" which do not offer decent working conditions and violate fundamental labour standards. ${ }^{56}$ A significant number, employing local workers, are found in the developing world. Some are linked to multinational companies through a complex network of subcontracting chains, from retailer down to production units. The production of international brands of garments, shoes, toys and sports equipment, among other things, has been targeted as sweatshop production involving child labour and female labour, mostly in forced labour conditions. This section discusses only "sweatshop" situations involving migrant labour.

174. "Sweatshops" have re-emerged in developed countries on the basis of cheap migrant labour. Trafficking and smuggling of persons provides a ready source of cheap forced labour for the sweatshops. The ILO report on the footwear, leather, textiles and clothing (TCF) industries points out that migrant workers constitute an important part of the TCF workforce in industrialized countries and in those developing countries which have progressed furthest along the road to industrialization. ${ }^{57}$

175. Concentrations of clandestine workshops are found in a number of European countries. These workshops employ large numbers of illegal migrants and use "labour practices that are contrary to the most rudimentary principles of respect for human rights at work". ${ }^{58}$ In the case of southern Europe, an ILO study found that migrants are mainly employed in manufacturing jobs that have the toughest conditions with respect to physical effort, endurance, overtime work and night shifts, as well as the highest risk of accidents. 59

176. In the United States, the problem of "sweatshops" has received much media attention. In August 1995, the case of 72 young Thai women who were being forced to work in conditions of near-slavery for a clothing enterprise in the Californian city of El Monte caused public outrage. More recently, Saipan (in the Commonwealth of the Northern Mariana Islands, administered by the United States) has attracted considerable media attention because of the slavery-like practices in "sweatshops" producing goods

\footnotetext{
55 ILO: The construction industry in the twenty-first century, op. cit. The ILO 1996 Tripartite Meeting recommended measures to provide for legal admission of construction workers and adequate protection for them in accordance with ILO and United Nations Conventions.

56 The word originated in the clothing industry where it has been used to refer to firms that required workers to work long hours to meet production targets without regard for their health and safety. See "The globalization of sweatshops", in Sweatshop Watch, Vol. 6(2), summer 2000, available online at http://www.sweatshopwatch.org/ swatch/newsletters/6_2.html (accessed 8 Mar. 2004).

57 ILO: Labour practices in the footwear, leather, textiles and clothing industries, report for discussion at the Tripartite Meeting on Labour Practices in the Footwear, Leather, Textiles and Clothing Industries, Geneva, 16-20 October 2000

58 ibid.

59 E. Reyneri: Migrants' involvement in irregular employment in the Mediterranean countries of the European Union (Geneva, ILO, International Migration Paper series, 2001).
} 
for major American distributors. More than 50,000 young female migrants from China, the Philippines, Bangladesh and Thailand were discovered working as virtual prisoners in workshops, forced to work 15 hours a day, seven days a week. Trade unions, NGOs and the United States authorities have joined forces to combat such sweatshop practices. As a result, a number of American clothing distributors have undertaken to finance an independent monitoring system to ensure that in future their suppliers in Saipan will respect basic workers' rights. The federal authorities have also launched a number of initiatives during recent years aimed at combating "sweatshops" with the support of major enterprises in the textiles sector. ${ }^{60}$ The United States Department of Labor collected US\$175 million in back wages for 263,593 workers during the financial year 2002 from low-wage industries including garment manufacturing. ${ }^{61}$

177. It is in clandestine workshops that violations of human rights at work are most common and most serious. The scale of the phenomenon, which is seen mainly in the clothing sector, is such that they pose a threat to the viability of legal enterprises because of the unfair competition which they represent. Voluntary private initiatives, including codes of conduct, can complement existing legislation and encourage the promotion of fundamental principles and rights in the workplace. In Europe, the European Trade Union Federation of Textiles, Clothing and Leather (ETUF:TCL) and the European Apparel and Textile Organisation (EURATEX) signed the first "European Code of Conduct" on 22 September 1997 to comply with and promote basic human rights in the workplace based on international norms. ${ }^{62}$

178. The ILO Tripartite Meeting on the TCF industries (2001) adopted a resolution which supports the promotion throughout the TCF industries of the ILO Declaration on Fundamental Principle and Rights at Work and the ILO Tripartite Declaration of Principles concerning Multinational Enterprises and Social Policy, as well as all relevant ILO Conventions and Recommendations. ${ }^{63}$

\section{(d) Services}

179. The world's economy is based predominantly on services: 64 per cent of the global GDP of US\$31 trillion in 2001 was accounted for by services according to the World Bank's assessment of value added, and 65 to 70 per cent of the workers in the more developed countries are employed in service-producing sectors. ${ }^{64}$ The composition of services changes with economic development and rising incomes, as educational, business and health services increase their share of GDP and personal services (such as private household help) decline. The fact that demand for migrant workers has ranged from highly skilled to unskilled workers also reflects this.

180. The distribution of foreign workers by sector in OECD countries highlights these structural changes. In the past few years, however, the tertiary or services sector has

\footnotetext{
60 ibid.

${ }^{61}$ http://www.dol.gov/opa/media/press/esa/ESA2002694.htm (accessed 10 Mar. 2004).

${ }^{62}$ A Charter by the Social Partners in the European Textile and Clothing Sector: Code of Conduct, text available online at http://www.unicz.it/lavoro/UECODET.htm (accessed 10 Mar. 2004).

${ }^{63}$ ILO: Resolution concerning future ILO action in the footwear, leather, textiles and clothing industries, Tripartite Meeting on Labour Practices in the Footwear, Leather, Textiles and Clothing Industries, Geneva, 16-20 October 2000, available online at http://www.ilo.org/public/english/dialogue/sector/techmeet/tmlfi00/ resolute.htm (accessed 8 Mar. 2004).

64 World Bank: World Development Report 2002 (Washington, DC, 2002).
} 
become more important for the employment of foreign workers and now employs more than three-quarters of all such workers in some countries (such as Australia, Luxembourg, the Netherlands, Norway and the United States). ${ }^{65}$ Sectoral distribution, however, varies significantly by country, although wholesale and retail trade, hotels and tourism, health and community services and household services appear to be the most important.

\section{Domestic service, nursing and other care services}

181. The demand for foreign household and care workers has grown in the OECD countries with rising female employment rates, changes in family structures and an ageing population leading to higher dependency ratios. ${ }^{66}$ Within this framework, the need for household services is expected to increase. According to the latest SOPEMI report (2003), more than 10 per cent of foreign workers in southern Europe are employed in household services, especially in Greece, Italy and Spain. In France and the United States, about 51,000 and 150,000 foreigners respectively provide care for the elderly and children at home. More than 950,000 Italian families hired foreign workers to tend to the needs of the elderly or children in 2002. Another important aspect of this is that many of these workers may be in irregular status as shown by regularization exercises. ${ }^{67}$ The issue of domestic workers is discussed in detail below.

182. In 2002, Citizenship and Immigration Canada established the Live-in Caregiver Program to allow foreign employers and caregivers to fill the need for live-in care work for children, elderly people or persons who have disabilities, ${ }^{68}$ in response to labour market shortages of Canadian citizens or permanent residents. Prior to this programme, Canada was providing permanent resident status (as housekeepers, servants or personal service providers) to only a very limited number of foreign workers. The Live-in Caregiver Program provides the possibility of applying for permanent residence in Canada after two years of employment.

183. Migration of health workers, especially nurses, has grown in recent years in response to high demand in developed countries such as the United States and United Kingdom. An ILO study has highlighted the problems faced by them, which include lack of recognition of skills and previous experience leading to systematic deskilling, channelling into "non-career" grades in unpopular specialties, and the "ethnic penalty" which results in restricted access to training and poorer career progression. ${ }^{69}$ The United Kingdom has introduced the international nurses' advice line, which offers advice to nurses working in England and who are experiencing problems with supervised practice placements and agencies who fail to honour the terms of contracts. ${ }^{70}$

\footnotetext{
${ }^{65}$ OECD: Trends in international migration 2003 (Paris, 2003), table I.12.

${ }^{66}$ ibid.

${ }^{67}$ ibid.

${ }^{68}$ Citizenship and Immigration Canada: The Live-In Caregiver Program, Fact Sheet 19, available online at http://www.cic.gc.ca/english/irpa/fs-caregivers.html (accessed 10 Mar. 2004).

69 S. Bach: International migration of health workers: Labour and social issues (Geneva, ILO, Sectoral Activities Programme, WP.209, 2003).

${ }^{70}$ ILC survey information.
} 


\section{Hotel, catering and tourism (HCT)}

184. Worldwide, employment within the tourism economy is estimated at 192.2 million jobs (one in every 12.4 jobs in the formal sector). By 2010, this should grow to 251.6 million jobs (one in every 11 formal sector jobs). The industry is heavily dominated by SMEs: in Europe, for example, there are 2.7 million SMEs operating in the sector, representing almost all HCT enterprises. Some 94 per cent of this segment are microenterprises employing fewer than ten people. SMEs employ over half the labour force working in the industry. ${ }^{71}$

185. Migrant workers in the tourism labour market of destination countries include daily commuters, seasonal workers and permanent migrants. The majority are drawn into lower-paid, informal or casual employment in services. Although many migrant workers stay for a number of years, they often remain at low skill levels compared to local workers. An ILO study equates their social status to that of ethnic minorities, another group strongly over-represented in the HCT sector. European countries such as Austria, Denmark, Germany and Switzerland employ large numbers of migrants. In 1996, the percentage of foreign workers in hotels and restaurants was 51.2 per cent in Switzerland and 30.9 per cent in Germany. In Spain, the coastal resorts employ large numbers of illegal migrants.

186. The hotel, restaurant and catering sector remains an area in which use is frequently made of undeclared labour. In some countries, this may involve the clandestine employment of illegal foreigners who are willing to accept less favourable conditions of employment than nationals. It may also take the form of employees being declared as working for a certain limited number of hours while actually working longer hours and receiving supplementary payments in cash, thus enabling both employer and employee to avoid payment of a proportion of social insurance contributions. Undeclared labour is employed mainly in small enterprises where cash is available outside the official accounts.

\subsection{Most vulnerable groups of workers ${ }^{72}$}

\section{(a) Women domestic workers}

187. Migrant women domestic workers are among the world's most vulnerable workers. Most are women moving from poorer to richer countries for economic reasons, and most leave their children behind, often in the care of relatives or a hired local maid, creating global care chains. The availability of foreign maids, in turn, allows women with children in destination countries to work for wages, so that many of the world's women between the ages of 15 and 64 years are able to pursue paid employment outside the home. $^{73}$

\footnotetext{
${ }^{71}$ ILO: Human resources development, employment and globalization in the hotel, catering and tourism sector, Report for discussion at the Tripartite Meeting on Human Resources Development, Employment and Globalization in the Hotel, Catering and Tourism Sector, Geneva, 2-6 April 2001.

72 A detailed discussion of these groups in Asia can be found in P. Wickramasekara: Asian labour migration: Issues and challenges in an era of globalization, International Migration Papers No. 57 (Geneva, ILO, 2002).

73 ILO: Preventing discrimination, exploitation and abuse of women migrant workers: An information guide, Booklet 1, Introduction: "Why the focus on women international migrant workers", Gender Promotion Programme, Geneva, p. 29.
} 
188. In some European countries (France, Greece, Italy and Spain) domestic work or housekeeping is the most common occupation open to female migrants. ${ }^{74}$ During the 1990s, numerous migrants with residence permits entered Italy, Greece and Spain as domestic workers through the quota system, and a large proportion of those regularized were domestic workers. High- and middle-income States in Asia, including Hong Kong (China), Singapore, Taiwan, China and Malaysia, and the Gulf States also employ large numbers of women migrant workers. In Costa Rica, domestic workers are drawn largely from neighbouring Nicaragua.

189. In Asia, the most important source countries of female migrant workers are Indonesia, Philippines and Sri Lanka. In these countries, women are a majority of migrants and many work abroad in services, including domestic work, health services and entertainment. There are differences in government policies toward women going abroad to be domestic workers, ranging from liberal to highly regulated systems. Countries such as Bangladesh and Pakistan ban the emigration of unskilled female workers altogether.

190. The admission of domestic workers usually occurs when rural-urban migration declines and rising incomes and employment opportunities draw local women away from work at home. But there are marked differences among countries. While Singapore in the 1980s sought to increase the labour force participation of women by opening the door to foreign domestic workers, Japan did not. ${ }^{75}$ In the Middle East, the admission of foreign domestic workers is not linked to the wage employment of native women. ${ }^{76}$

191. Working conditions of domestic workers vary enormously. Some are treated as members of their employer's family, while others are exploited and subjected to conditions which in some cases amount to virtual slavery and forced labour. Domestic workers often have to work long or even excessive hours of work (on average, 15-16 hours per day), with no rest days or compensation for overtime; they generally receive low wages, and have inadequate health insurance coverage ${ }^{77}$ Domestic workers are also exposed to physical and sexual harassment and violence and abuse, and are in some cases trapped in situations in which they are physically or legally restrained from leaving the employer's home by means of threats or actual violence, or by withholding of pay or identity documents. ${ }^{78}$

192. Wage discrimination by nationality is experienced by domestic workers in most countries in Asia and the Middle East. Filipinos generally earn the highest wages among domestic workers, partly because of their knowledge of English and awareness of local laws and regulations. Most Indonesian and Sri Lankan maids do not receive the legal minimum wage. ${ }^{79}$ A similar pattern has been observed in the Middle East for domestic

\footnotetext{
74 E. Reyneri, 2001, op. cit., p. 37.

75 The "side doors" opened for trainees and ethnic Japanese from Brazil and Peru confined migrants largely to manufacturing and construction.

${ }^{76}$ In the Gulf States, most women who work are in government services, and married women in Kuwait aged 40 years or over can retire with full benefits after 15 years of employment; about 90 per cent of Kuwaitis work for the Government.

77 ILO: Information guide, op. cit., Booklet 4, "Working and living abroad".

78 ILO: Information guide, op. cit.

79 N. Oishi: Women in motion: Globalization, state policies, and labor migration in Asia (Stanford University Press, forthcoming).
} 
workers: the ILO Bahrain study found that "wages are determined according to the nationality of the female domestic workers instead of their experience". ${ }^{80}$

193. In some countries, domestic workers are required to undergo compulsory periodic pregnancy tests. If they test positive, they are immediately deported. Such tests are prohibited by the Maternity Protection Convention, 2000 (No. 183). In Italy, a new general national contract for domestic employment enacted on 8 March 2001, introduced an important new provision against the dismissal of pregnant women workers from the moment of pregnancy (the only exception being dismissal for lawful cause).

194. The very nature of domestic household work gives rise to complex protection issues. ${ }^{81}$ In many countries, labour, safety, and other laws do not cover domestic workers, so that there are no legal norms for their treatment or offices and inspectors to enforce them. Even if they are protected by legislation, it can be very difficult for domestic workers to learn about or benefit from available protections, the result being widespread violations of protective labour laws.

\section{(b) Migrant workers in irregular situations}

195. Irregular migration results from a variety of causes, as explained in Chapter 1. Given their precarious legal position in the host country, irregular migrant workers easily fall prey to extortion and are highly vulnerable to abuse and exploitation by employers, migration agents, corrupt bureaucrats and criminal gangs. According to the United Nations Office of the High Commissioner for Human Rights (UNOCHR): "migrant workers face the gravest risks to their human rights and fundamental freedoms when they are recruited, transported and employed in defiance of the law". ${ }^{82}$ Women in an irregular status are doubly vulnerable, owing to the high risk of sexual exploitation to which they are frequently exposed. The basic human rights of migrants in an irregular status are thus often violated, despite the protection they should receive under the general international human rights instruments ratified by most countries. ${ }^{83}$

196. Even workers who enter a country legally fall into illegal status as a result of false information given by recruiters or of losing their jobs. ${ }^{84}$ Fear of detection and possible deportation deters migrant workers from availing themselves of even those services offered to them. In short, they are not able to "secure for themselves protection against hazards to their health and safety, join unions or organize themselves for collective

\footnotetext{
${ }^{80}$ S. al-Najjar: Women migrant domestic workers in Bahrain (Geneva, ILO, International Migration Papers, No. 47, 2002).

${ }^{81}$ F.M. Ramirez-Machado, Domestic work, conditions of work and employment, op. cit.

${ }^{82}$ UNOHCHR: The rights of migrant workers, human rights Fact Sheet No. 24, Geneva, United Nations, 1996.

${ }^{83}$ P. Wickramasekara: Migrant workers in Asia and the Pacific: Issues in human rights and the principle of nondiscrimination, Paper prepared for the Asia-Pacific Regional Seminar of Experts in preparation for the World Conference on Racism, Xenophobia and Related Intolerance, organized by the OHCHR, Bangkok, 5-7 September 2000 .

${ }^{84}$ M. Ellman and S. Laacher: Migrant workers in Israel - A contemporary form of slavery, Report of a joint mission by the Euro-Mediterranean Human Rights Network and the International Federation for Human Rights (Paris, 2003), available online at http://www.fidh.org/magmoyen/rapport/2003/il1806a.pdf (accessed 10 Mar. 2004). The mission was alarmed to find that, of approximately 300,000 foreign workers brought into Israel, more than 65 per cent (over 200,000) are illegal, and that many migrant workers who go to Israel because they have been promised a job discover upon arrival that no such job exists.
} 
bargaining, obtain fair wages, ask for compensation in case of injury or illness, or have any security of employment". ${ }^{85}$

197. The Platform for International Cooperation on Undocumented Migrants (PICUM) sums up the European situation as follows:

Undocumented migrants residing in Europe are socially excluded and very vulnerable to marginalization. Europe needs and makes use of the labour of undocumented migrants, but at the same time is not willing to give any rewards for their contributions. Undocumented migration is fought in many ways, including by blocking access to basic social services. It is alarming that there has been a tendency to criminalize undocumented migrants themselves and penalize the social and humanitarian assistance that citizens and civil organizations offer them. ${ }^{86}$

198. The provisions in international instruments to curb irregular migration are discussed in Chapter 4. If root causes are to be addressed, creation of more legal migration opportunities will be essential. The conclusions of the ILO Asia Regional Tripartite Meeting in Bangkok (30 June-2 July 2003) pointed out that easy and transparent access to legal migration opportunities could be part of an effective response to the problem. At the ILO Workers' Consultation also, there was a strong view that legal migration should be facilitated as a means of combating trafficking and irregular movements. ${ }^{87}$

199. The popular official response has been to intensify border controls and deportation procedures - "more policing" instead of "better policies". Yet experience has shown that these are of limited effectiveness. As the United Nations Secretary-General succinctly put it:

Few if any States have actually succeeded in cutting migrant numbers by imposing such controls. The laws of supply and demand are too strong for that. Instead, immigrants are driven to enter the country clandestinely, to overstay their visas, or to resort to the one legal route still open to them, namely the asylum system. ${ }^{88}$

He adds that such measures lead "almost inevitably" to human rights violations. A recent study of unauthorized migration in four South-East Asian countries comes to similar conclusions: "[...] experience shows that this approach [keeping our borders tightly guarded] has not succeeded in keeping all unwanted persons out. It does succeed in rendering many unauthorized persons - who form the backbone in some sectors without protection from insecurity and abuse." 89

200. Another disturbing trend highlighted by the United Nations Special Rapporteur on Human Rights of Migrants is the practice of administrative detention instead of recourse

\footnotetext{
${ }^{85}$ M. Abella: Protecting temporary migrant workers: Challenge for modernizing States in Asia, Paper presented at the Workshop on International Migration and Labour Markets in Asia, 28-29 January 1999, Tokyo.

${ }^{86}$ PICUM: Book of Solidarity Volume/01: Providing assistance to undocumented migrants in Belgium, Germany, the Netherlands and the UK, Brussels, 2002.

${ }^{87}$ ILO: Regional Tripartite Meeting, Summary of conclusions, op. cit.; Report of the Workers' Consultation on Migrant Workers, op. cit.

${ }^{88}$ K. Annan: Emma Lazarus Lecture on International Flows of Humanity, Columbia University, New York, 21 Nov. 2003.

${ }^{89}$ G. Battistella and M.M.B. Asis (eds.): Unauthorized migration in Southeast Asia (Quezon City, Philippines, Scalabrini Migration Center, 2003).
} 
to judicial processes. ${ }^{90}$ Contrary to international norms, there have recently been mass deportations of undocumented migrant workers in some Asian and African countries, causing serious violations of human rights in the process. Many migrant holding centres are overcrowded and unhygienic and conditions of detention do not respect international norms, standards and principles, and inhumane or degrading treatment of migrants is not uncommon. $^{91}$

\section{(c) Trafficked persons}

201. Trafficking of human beings represents a violation of the fundamental rights and core labour standards enshrined in the ILO Declaration - those relating to forced labour, discrimination and freedom of association, and not infrequently also child labour. ${ }^{92}$ It constitutes an antithesis of any notion of decent work. The consequences are that:

... the trafficking victim will be at the mercy of the traffickers and, far from being able to find work to begin to build a better future, will be forced to labour to pay off debts, as a result of fear of disclosure, violence or reprisals. This labour is likely to be performed without a contract, time off, insurance, access to health or social security services or pay, and often for long hours in the kind of work too often reserved for low-skilled migrant workers: in sweatshops, agriculture, construction work, domestic service, food processing or labourintensive manufacturing and, of course, for women and older girls, in commercial sex. Such exploitation is at the heart of trafficking. ${ }^{93}$

202. According to the ILO Global Report on forced labour: "The recent rise in labour trafficking may basically be attributed to imbalances between labour supply and the availability of legal work in a place where the jobseeker is legally entitled to reside". ${ }^{94}$ Smuggling occurs because borders have become barriers between jobseekers and job offers. Trafficking occurs not only when borders are barriers to labour supplies meeting demands, but when no knowledge is available about proper migration channels, when employment is itself illegal and/or underground, and where conditions of work below the legal minimum are tolerated or ignored. ${ }^{95}$

203. Those who recruit people to be trafficked often create the conditions for forced labour by entering into loan agreements with migrants and putting them into debt bondage, by facilitating undocumented (or falsely documented) migration, so that migrants are vulnerable to threats of deportation, or by giving them false information on the nature or place of work they are going to. Victims of trafficking may be in economic sectors where they are hard to detect, such as agriculture, domestic service and sex work.

204. As with child labour, there has been a substantial degree of convergence at the international level on combating trafficking, with a number of countries taking action.

\footnotetext{
${ }^{90}$ United Nations Commission on Human Rights: Specific groups and individuals: Migrant workers, Report of the Special Rapporteur (Geneva, doc. E/CN.4/2003/85, 30 Dec. 2002).

91 ibid. See also: Asia MetaCentre for Population and Sustainable Development Analysis: Health consequences of population changes in Asia: What are the issues?, Research Paper Series, No. 6 (Singapore, 2002).

92 ILO: Stopping forced labour, Report of the Director-General, Report IB, Global Report under the follow-up to the ILO Declaration on Fundamental Principles and Rights at Work, International Labour Conference, 89th Session, Geneva, 2001.

93 ILO: Trafficking in human beings: New approaches to combating the problem, Geneva, Special Action Programme to Combat Forced Labour (Geneva, 2003).

94 ILO: Stopping forced labour, op. cit., p. 53.

95 ibid.
} 
The international legal framework has been strengthened by the ILO Declaration and the United Nations Convention against Transnational Organized Crime and the related Palermo Protocol. ${ }^{96}$ A number of agencies including the International Organization for Migration have been actively assisting countries in combating trafficking. ${ }^{97}$ The United States in 2000 enacted the Trafficking Victims Protection Act that mandated the State Department to produce an annual report assessing the efforts of governments around the world to meet minimum standards in combating trafficking. Economic sanctions may be imposed on countries that do not take measures to combat trafficking effectively. There has also been considerable international cooperation between other source and destination countries. Australia's Department of Immigration and Multicultural and Indigenous Affairs, for example, has an extensive system of compliance and enforcement within the country. Australia was also co-organizer of the Regional Ministerial Conference on People Smuggling, Trafficking in Persons and Related Transnational Crime in Bali in 2002. In cooperation with UNICEF and international NGOs, the Government of Japan held the Second World Congress against Commercial Sexual Exploitation of Children in December 2001.

205. There are also a number of anti-trafficking activities in Europe. Iceland, for example, which is part of the Nordic-Baltic Campaign Against Trafficking in Women, carries out public information campaigns about trafficking, and also advises women who apply to come to Iceland as "dancers", informing them of their legal rights. Many States (for example, Belgium, the Netherlands, Spain and the United States) have adopted legislation that allows victims of trafficking to stay temporarily in the country, some on grounds of social protection (as in Italy) or, more generally, on condition that victims collaborate actively in the prosecution of traffickers. Also in Europe, in 2002 a proposal was submitted for a Council Directive on a short-term residence permit issued to victims of smuggling or trafficking who cooperate with the competent authorities.

206. To date, most counter-trafficking measures have focused on law enforcement and control measures. What is needed in the longer term is an effort to create productive employment in countries of origin, and access to legal migration channels to match labour market needs in destination countries. A comprehensive response framework must cover the following elements: treating trafficking as a distinct crime; addressing the root causes of supply and demand; promoting a standards-based approach and measures to protect the human rights of all workers, supported by adequate legal frameworks and effective enforcement; work towards more regulated, orderly and humane labour migration systems; and mobilization of all social actors. ${ }^{98}$

\footnotetext{
${ }^{96}$ P. Taran and G. Moreno-Fontes: Getting at the roots: Stopping exploitation of migrant workers by organized crime, Paper prepared for an International Symposium on the United Nations Convention against Transnational Organized Crime, Turin, 22-23 February 2002 (Geneva, ILO, 2002).

97 IOM: Trafficking in migrants: IOM policy and responses (Geneva, 2001), available at http://www.iom.int/en/ who/main_policies_trafficking.shtml (accessed 10 Mar. 2004).

98 See ILO: Preventing discrimination, exploitation and abuse of women migrant workers: An information guide, Booklet 6 "Trafficking of women and girls", Gender Promotion Programme, Geneva. Anti-Slavery International: The migration-trafficking nexus: Combating trafficking through the protection of migrants' human rights, London, Nov. 2003.
} 


\subsection{Occupational safety and health issues}

207. There are two aspects of health issues for migrant workers: (a) occupational safety and health (OSH) at the workplace; and (b) general health conditions of the workers and their families. These are closely interrelated. OSH is an important issue for migrant workers for several reasons. ${ }^{99}$ Firstly, migrant workers tend to be employed in high-risk sectors; ${ }^{100}$ secondly, language and cultural barriers require specific OSH communication, instructions and training approaches; and thirdly, many of these workers overwork and/or suffer from poor general health and are therefore particularly prone to occupational injuries and work-related diseases.

208. Out-migration or international migration often results in increased levels of precariousness and higher risk of adverse health outcomes. ${ }^{101}$ Occupational accident rates are about twice as high for migrant workers as for native workers in Europe, and there is no reason to believe that the situation is any different in other parts of the world. ${ }^{102}$ Many migrants, especially seasonal migrants, are placed in high-risk, low-pay jobs with poor supervision. Linguistic obstacles, lack of familiarity with modern machinery, and different attitudes to safety are all factors that increase work-related risks. Migrant workers often accept these dangerous working conditions for fear of bringing attention to themselves and losing their jobs or being deported.

209. The conclusions of the ILO Tripartite Meeting on Migration in Asia succinctly sums up the situation: ${ }^{103}$

Safety and health issues for migrant workers are a major concern as they may be involved in hazardous and risky jobs. Language barriers, exposure to new technology, family disruption, poor access to healthcare and stress and violence, are the specific problems faced by migrant workers leading to higher vulnerability to safety and health risks at the workplace.

210. The ILO report on standards-related activities in $\mathrm{OSH}^{104}$ highlighted the need for strategies to take account of the increased vulnerability of certain groups such as women, older workers and migrant workers. The related survey found that specific OSH measures for migrant workers and older workers were less prevalent than for other categories of workers.

\footnotetext{
${ }^{99}$ For a general reference on the issue, see ILO: Safety and health of migrant workers: International Symposium (Occupational Safety and Health Series, 1983); article on "Migrant and seasonal farm workers", ILO Encyclopaedia of occupational health and safety, 4th edition (1998), Vol. 3.

100 The ILO regards agriculture, mining, construction and informal sector work - areas where migrants are concentrated - as "especially hazardous".

101 ILO: ILO standards-related activities in the area of occupational safety and health: An in-depth study for discussion with a view to the elaboration of a plan of action for such activities, Report VI, International Labour Conference, 91st Session, Geneva, 2003.

102 S. Braunschweig and M. Carballo: Health and human rights of migrants, Geneva, World Health Organization and International Centre for Migration and Health, Geneva, 2001.

103 ILO: Summary of conclusions, ILO Regional Tripartite Meeting on Challenges to Labour Migration Policy and Management in Asia, 30 June-2 July 2003, Bangkok.

104 ILO: ILO standards-related activities in the area of occupational safety and health, op. cit.
} 
211. According to one report on the United States, "Migrant farm workers have a thirdworld health status, although they live and work in one of the richest nations on earth". ${ }^{105}$ It also states that:

Poverty; frequent mobility; low literacy; language, cultural and logistic barriers impede farm workers' access to social services and cost-effective primary health care. Economic pressure makes farm workers reluctant to miss work when it is available. In addition, they are not protected by sick leave, and risk losing their jobs if they miss a day of work. These circumstances cause farm workers to postpone seeking health care unless their condition becomes so severe that they cannot work.

A survey of farm worker health issues concluded that migrant farm workers have different and more complex health problems than from those of the general population, and that they also suffer more frequently from infectious diseases. ${ }^{106}$

212. Temporary workers, and in particular migrants in an irregular status, are often unable to access social security benefits such as health insurance and employment injury coverage. ${ }^{107}$ In addition, they often resist seeking medical treatment because of the cost, inability to take time off work, lack of childcare, and problems of transportation. Many are unfamiliar with the local health-care systems and may have linguistic or cultural difficulties in communicating their problems. These problems are compounded for irregular migrants and trafficked persons.

213. In a number of countries, there is also stereotyping of migrant workers as a "threat" to public health and as disease carriers without any solid evidence. This leads to further discrimination.

214. As reported in the ILM Survey, temporary or guest workers in Canada, for example, may have to pay a small fee for medical consultations, while irregular workers would not normally have access to public health facilities, although they would not be denied emergency treatment. In New Zealand, although the system is under review, people who do not expect to stay for more than two years are not entitled to free treatment and would have to pay for emergency care. In Mexico, irregular migrants would be allowed treatment only in an emergency. In other countries, such as Portugal, the provision of health facilities for migrants depends on a reciprocal arrangement with the source country. In the United States, it is estimated that fewer than 20 per cent of all migrant farm workers have access to quality health care. ${ }^{108}$

215. Migrant workers and members of their families face higher risks of HIV/AIDS infection than the stationary population but often face restricted access to disease prevention, detection and treatment. ${ }^{109}$ Those employed in mining, seasonal agriculture, temporary work or migratory trade, who have to live away from spouses and partners and work in geographically isolated areas with limited health-care facilities, are

\footnotetext{
105 National Center for Farmworker Health: Facts about farmworkers, Buda, Texas, 2004, available online at http://www.ncfh.org/factsheets.shtml (accessed 10 Mar. 2004).

106 ibid. See also Migrant Health Issues, Monographs 1-10, produced for the National Advisory Council on Migrant Health by the National Center for Farmworker Health, Inc., Buda, Texas, 2001.

107 On the issue of social security coverage for migrant workers, see Ch. 4.

108 C. Beck: "Migrant farm workers under the new regime", in Human Rights Brief (Washington, DC, American University, Center for Human Rights and Humanitarian Law), Vol. 5(1), 1997, available online at http://www.wcl.american.edu/hrbrief/v5i1/html/migrant.htm (accessed 9 Mar. 2004).

109 ILO: Meeting Report 3, Technical workshop on population mobility, migration and HIV/AIDS, held in Geneva on 18 March 2002.
} 
particularly at risk. The problems are compounded where they face discrimination or where there is a general lack of respect for human rights. ${ }^{110}$

216. Migrants are often concentrated in poor areas with substandard housing. Temporary and seasonal migrants face serious housing problems and tend to cluster in makeshift accommodation or in shanty towns. There is a vicious circle linking poor housing, hazardous working conditions and social disruption, and the spread of disease among migrant workers. ${ }^{111}$ One study in South Africa has found that migrant workers and their partners are about twice as likely to be infected with HIV as non-migrant couples. ${ }^{112}$ According to the World Economic Forum, almost 5 per cent of (internal) migrant workers in China and India are HIV-infected. ${ }^{113}$ While Filipinos working and living abroad constitute 10 per cent of the Philippine population, 28 per cent of the total number of reported HIV/AIDS cases are among migrant workers. ${ }^{114}$

217. The ILO code of practice on HIV/AIDS and the world of work provides important guidelines on the development of workplace policies and programmes on HIV/AIDS. ${ }^{115}$ While the code recognizes the workplace as a major entry point in the fight against HIV/AIDS, with trade unions and employers playing an important role, the fact that migrant workers are often not allowed to join trade unions and participate in their activities can be considered an obstacle to the campaign for health and safety. There are positive initiatives among some large multinational corporations to ensure affordable and accessible health care for migrant workers and their families. Box 3.1 highlights the role of the Global Business Coalition on HIV/AIDS.

\section{Box 3.1 \\ Global Business Coalition on HIVIAIDS}

The Global Business Coalition (GBC) on HIVIAIDS is a rapidly expanding alliance of more than 130 international businesses - with over 4 million employees in 178 countries dedicated to combating the AIDS epidemic through the business sector's unique skills and expertise. Many leading global companies are now members. Activities include:

- implementing prevention and care programmes and policies for employees and immediate communities - in many countries company programmes will be the only source of accurate HIV information available to employees;

a bringing business core strengths of creativity and flexibility to improve the reach and effectiveness of AIDS programmes - the marketing, communication, distribution and logistics skills of businesses are already strengthening the impact of many AIDS programmes around the world;

- leadership and advocacy by business leaders, lobbying for greater action and partnerships with governments and civil society. The GBC has joined the Business Sector Delegation to the Global Fund on AIDS, Malaria and TB to lobby governments and United Nations agencies to find innovative ways of collaborating with business using the sector's expertise and creativity.

Source: http://www.businessfightsaids.org/default.asp

\footnotetext{
${ }^{110}$ S. Braunschweig and M. Carballo, op. cit.

111 ibid.

112 ibid.

113 World Economic Forum: Scenarios: The global HIV-AIDS crisis, Annual Meeting, Davos, 2003, available online at http://www.weforum.org/pdf/Initiatives/GHI_2003_HIVAIDS_Scenario.pdf (accessed 9 Mar. 2004).

114 World Economic Forum: Join the fight against AIDS in the Philippines, available online at http://www.weforum.org/pdf/Initiatives/Philippines_menu_1.pdf (accessed 10 Mar. 2004).

115 ILO: HIV/AIDS and the world of work, ILO code of practice, Geneva, 2001.
} 


\subsection{Integration of migrant workers in host countries}

218. Poor integration of migrants in host societies is highlighted by a number of indicators. First, the high unemployment rates of migrant workers cited above show poor labour market integration. Migrants are absorbed into employment at much lower levels than would be warranted by their qualifications and many countries fail to recognize their experience or skills. The incidence of discrimination and xenophobia was discussed in section 3.3. Second-generation migrants also face serious employment problems. Migrants tend to be clustered in enclaves or "ghettos", forced by economic circumstances to live in poor housing areas (i.e. abandoned inner cities) and to congregate because of the need for mutual support. There is widespread stereotyping of migrants as criminals, "scroungers", and a threat to public safety and to health systems.

219. Integration is among the most difficult challenges raised by international migration today. Finding workable balances between host community respect for difference and immigrant participation remains extremely difficult for most countries. The integration policy dilemmas faced by many States are rarely separable from more general debates on discrimination and race relations within host communities. Successful integration will also depend on success in curbing racism and xenophobia. The report of the Workers' Consultation points out that: "Trade unions have a particularly important role in facilitating migrant workers' integration, thanks to their presence at the workplace and their democratic procedures. Failure to integrate migrants makes them prey to extremists and threatens democracy". ${ }^{116}$ The growth of clandestine and irregular migration provides fodder for extremist political parties to push for restrictions. Strong border control is often advocated as necessary for the acceptance of racial, cultural or ethnic minorities by the dominant culture. Temporary status for refugees or guest workers, for example, is not conducive to integration. In many countries, access to citizenship is a lengthy, sometimes almost impossible, process and might not necessarily prove to be in the best interests of either the migrants or the host community. Integration is, however, one approach for migrants to realize full legal protection for their fundamental human rights.

220. While temporary guest worker programmes are again growing in number and dimensions in Europe, and while in Asia the growth of migration over the past two decades has been almost entirely in the form of short-term contract labour, the reality is that some employers become dependent on foreign workers. Similarly, once foreign workers have worked for some time in a destination country, family and social ties are established and deepened in the new land. While incentives may encourage some workers to return to their own countries, conditions in both home and host countries compel many migrants - including those admitted under temporary programmes - to stay for extended periods. The challenge is to ensure that those who stay become productive participants in destination countries. Whether or not they are integrated depends on the policies adopted. The alternative, already faced today in a number of European countries and elsewhere, is marginalization of entire communities into increasingly isolated ghettos and perceived crises that may threaten social cohesion. The EU has adopted a number of initiatives to promote integration (see box 3.2).

116 ILO: Report of the Workers' Consultation on Migrant Workers, op. cit. 


\section{Box 3.2}

\section{Integration of third country nationals in the European Union}

In October 1999, at the European Council meeting in Tampere (Finland), the leaders of the European Union called for a common immigration policy which would include more dynamic strategies to ensure the integration of third-country nationals legally resident in the Union. At their meeting in Thessaloniki in June 2003, the Council set out a strategy for the development of a comprehensive and multidimensional policy on integration for the Union based on the principle, agreed at Tampere, of granting legal immigrants rights and obligations comparable to those of EU citizens.

The Council mapped out a holistic policy, which takes into account not only the economic and social aspects of integration, but also issues related to cultural and religious diversity, citizenship, participation and political rights - planned within a longterm, coherent and overall framework. The Council emphasized that the policy must be responsive to gender, to the specific needs of particular groups and to local conditions, and stressed that its effectiveness depended on the establishment of partnerships between a wide range of stakeholders together with the provision of adequate resources.

In its Communication on Immigration, Integration and Employment of June 2003, the European Commission made proposals for reinforcing integration at both EU and national level with respect to the main areas of this holistic policy, which were defined as:

a integration into the labour market;

a access to education and language skills;

- access to housing and comprehensive urban and regional planning;

a access to health and social services;

a active involvement and participation in civil life;

a nationality, civic citizenship and respect for diversity.

Integration into the labour market is seen as a key element in EU integration policy. The European employment guidelines for 2003 have, accordingly, been revised to require Member States to implement measures and set targets to ensure the integration into the labour market of migrant workers, to reduce the unemployment gap with nationals, and to tackle more effectively the transformation of undeclared work into legal employment. Integration measures are already supported by a range of EU policies and programmes notably in the field of social cohesion, anti-discrimination and via the Structural Funds. Financial support was strengthened by the introduction in 2003 of a specific programme of pilot projects on the integration of migrants. In addition a number of steps are being taken at EU level to promote the exchange of information and good practice between Member States with respect to integration policy with a view to improving integration policy and, in the longer term, defining common objectives. The Commission is also reviewing the concept of civic citizenship as a means of promoting integration within the framework of the Charter of Fundamental Rights, since most of its provisions are applicable to all persons, irrespective of their nationality. The Commission acknowledges that naturalization in itself can promote integration and it is, therefore, promoting the exchange of information and best practice in relation to Member State's nationality laws.

Source: European Commission.

221. The social partners play a key role in integration. On the basis of the experience of social partner organizations in Belgium, Ireland, the United Kingdom, the United States and other countries, the ILO has facilitated the development of a methodology for promoting integration in workplaces. The approach recognizes that integration requires deliberate, multiple and sequential steps by both immigrants and host institutions and individuals over time. 


\subsection{Preliminary conclusions}

222. Migrants often face multiple disadvantages. As temporary workers they often have limited legal rights. Most can only find employment in sectors where wages are squeezed because producers are in highly competitive end of global production chains. Trends towards more flexible employment relationships, gender discrimination, abuses in recruitment and irregular status compound these disadvantages, and have led to the greater vulnerability of most migrant workers. Governments have a responsibility to comply with the equal treatment pledges in their constitutions and international treaties. Much needs to be done to ensure the equal treatment of migrants, especially those most liable to abusive situations such as domestic workers, and to minimize their exploitation, forced labour, smuggling, and trafficking.

223. There are best practices which can inspire improvements in working conditions for migrants, including having competent institutions to supervise recruitment and migration, encouraging migrants to sign contracts whose provisions have been approved by competent national authorities, including migrants workers under work-related health programmes, and establishing specialized agencies to monitor and seek to reduce discrimination. Workers' organizations have networked to provide greater protection to migrant workers, and also adopted an action plan against racism and discrimination. In several countries, private businesses have taken the initiative to improve their housing and living conditions and health care.

224. The complexity of the issues means that responses have to be comprehensive and multi-pronged, based on the one hand on international norms, and on the other on a better understanding of economic forces at play which shape working conditions in different sectors. A sound framework for improving the conditions of employment of migrant workers will need to draw on multilateral or inter-state cooperation, good governance, labour market regulation, joint liability of subcontractors and enterprises or employers, appropriate laws and their enforcement, and effective mobilization of social partners and other concerned agencies. The next chapter reviews the scope of international instruments and their relevance. 


\section{Chapter 4}

\section{International regulation of migrant workers and migration}

\subsection{Introductory remarks}

225. International regulation and guidance are an essential foundation for national legislation, policy and practices which are required to address effectively the issues raised in previous chapters. Indeed, a large array of international standards already exists to provide parameters for the regulation of international migration in such a way as to contribute towards strengthening the rule of law. Several complementary instruments offer relevant standards in areas such as human rights, labour, criminal law and refugees. The current regulatory system is multi-layered, reflecting efforts to protect migrant workers' rights and address problems related to migration at the multilateral, regional, bilateral and national levels. As will be examined below, the ILO has a comprehensive system of standards coupled with a unique tripartite supervisory mechanism, including scrutiny by independent legal experts.

226. Among the abovementioned standards, the ILO has adopted two Conventions and two Recommendations addressing most migrant workers' concerns. Following a review of these instruments in the context of the ILO's examination of the need for revision of ILO standards, ${ }^{1}$ the Governing Body concluded that further information was required in order to determine the status of these instruments and whether they required revision. As a result, a detailed examination of these four instruments was carried out in $1998^{2}$ and discussed at the 87th Session of the International Labour Conference in 1999, where a lack of consensus on future directions for these instruments became clear. ${ }^{3}$ It was therefore agreed that a general discussion should be held at a future session of the Conference, including on the possible need for additional standard-setting activities in this area.

227. Against this background, the following examination focuses on developments since 1999 and is aimed at providing further information on whether current international standards including, but not limited to, the four comprehensive ILO instruments fully address the problems facing migrant workers in the current political context of

\footnotetext{
${ }^{1}$ Carried out by the Governing Body from 1995 to 2002 and based on the work of the Working Party on Policy regarding the Revision of Standards of the Committee on Legal Issues and International Labour Standards.

${ }^{2}$ In the form of a General Survey based on reports requested from member States pursuant to article 19 of the ILO Constitution. See ILO: General Survey on migrant workers, Report III(1B), International Labour Conference, 87th Session, Geneva, 1999 (subsequently referred to as General Survey, 1999).

${ }^{3}$ ILO: Report of the Committee on the Application of Standards, International Labour Conference, 87th Session, Geneva, 1999, paras. 134-175.
} 
international migration. In this examination account is taken not only of the four specific ILO instruments but also of other relevant ILO standards, as well as other international regulatory systems, in particular those developed within the United Nations.

\subsection{Current international regulation}

\section{Instruments developed by the ILO}

228. Instruments relevant to migrant workers include the specific Conventions Nos. 97 and 143 and their accompanying Recommendations, and the ILO's instruments on fundamental principles and rights as well as - in principle - all other ILO standards.

229. According to the 1998 ILO Declaration on Fundamental Principles and Rights at Work and its Follow-up ("the 1998 Declaration"), all ILO member States have an obligation - arising from the very fact of membership of the Organization - to respect, to promote and to realize, in good faith and in accordance with the Constitution, four categories of principles and rights at work, even if they have not ratified the Conventions to which they refer: freedom of association and the effective recognition of the right to collective bargaining; the elimination of all forms of forced or compulsory labour; the effective abolition of child labour; and the elimination of discrimination in respect of employment and occupation. The fundamental principles and rights at work are universal and applicable to all people in all States, regardless of the level of economic development. They thus apply to all migrant workers without distinction, whether they are temporary or permanent migrant workers, or whether they are regular migrants or migrants in an irregular situation. In addition, the 1998 Declaration makes specific reference to groups with special needs, specifically including migrant workers.

230. The recognition of the special status of these fundamental principles and rights has evolved over the past ten to 15 years, and they are the essence of the eight "core" ILO Conventions, which express in more detail and in a formal legal structure the scope and content of these fundamental principles and rights. The ILO's campaign for the universal ratification of these instruments has been very successful, and the levels of ratifications of these Conventions have soared over the past decade. All these standards, which cover migrant workers along with all other workers, are thus binding on a large majority of ILO member States.

\section{Fundamental principles and rights at work}

Freedom of association and collective bargaining

231. The Freedom of Association and Protection of the Right to Organise Convention, 1948 (No. 87), ${ }^{4}$ and the Right to Organise and Collective Bargaining Convention, 1949 (No. 98), ${ }^{5}$ are the two basic Conventions that deal with freedom of association. Convention No. 87 guarantees the right, freely exercised, of workers and employers, without distinction, to organize for furthering and defending their interests. Convention No. 98 protects workers and employers who exercise the right to organize, forbids interference in the activities of workers' and employers' organizations and promotes voluntary collective bargaining. Representation and a voice at work are important means

\footnotetext{
4142 ratifications as at 12 Feb. 2004

5154 ratifications as at 12 Feb. 2004.
} 
through which migrant workers can secure other labour rights and improve their working conditions.

232. The denial of trade union rights and anti-union discrimination against migrant workers, even those in an irregular situation, ${ }^{6}$ by countries that have ratified these Conventions has been the subject of comments by the Committee of Experts on the Application of Conventions and Recommendations (CEACR) and by the Committee on Freedom of Association (CFA), which have repeatedly reaffirmed the fundamental rights of workers, including migrants, to form and join trade unions and to be protected against any act of discrimination on the grounds of trade union activities.

233. According to the CEACR, provisions on nationality that are too strict run the risk of depriving some workers of the right to elect their representatives in full freedom, for example migrant workers, in sectors where they account for a significant proportion of the workforce. National legislation should also allow foreign workers to take up trade union office, at least after a reasonable period of residence in the host country. ${ }^{7}$

\section{Abolition of forced labour}

234. The ILO has defined the incidence of forced labour in relation to migrant workers, particularly as a result of cross-border trafficking, as a major area of concern. ${ }^{8}$ Practice shows that migrant workers in an irregular situation are more at risk of being lured into situations of forced labour, including trafficking, and the illegal exaction of forced labour often implies an irregular status of the migrant worker concerned, whether this is due to his or her irregular or undocumented entry or stay, or to the illegal employment situation of the worker. The Forced Labour Convention, 1930 (No. 29), ${ }^{9}$ and the Abolition of Forced Labour Convention, 1957 (No. 105), ${ }^{10}$ prohibit forced and compulsory labour of all persons, irrespective of the type or location of their economic activity. On several occasions, the ILO supervisory bodies have expressed increased concern about the illegal exaction of forced labour, including debt bondage of migrant workers in agricultural and non-agricultural sectors, and trafficking of men and women migrant workers in agriculture, the sex industry and domestic service. ${ }^{11}$ They have also

\footnotetext{
${ }^{6}$ With respect to migrant workers in an irregular situation, the Committee on Freedom of Association considered that Article 2 of Convention No. 87 "recognize[d] the right of workers, without distinction whatsoever, to establish and join organizations of their own choosing without previous authorization. The only permissible exception to Convention No. 87 [was] that set out in Article 9 concerning the armed forces and the police". (ILO: 327th Report of the Committee on Freedom of Association, Governing Body, 283rd Session, Geneva, March 2002, GB.283/8, para. 561.) In the Hoffman case, in contrast with the foregoing case, it was not questioned that migrant workers in an irregular situation should enjoy the fundamental right to freedom of association. What was at stake concerned the remedial measures available in cases of illegal dismissals of undocumented workers in order to ensure effective protection against acts of anti-union discrimination. (ILO: 332nd Report of the Committee on Freedom of Association, Governing Body, 288th Session, Geneva, November 2003, GB.288/7 (Part II), Case No. 2227).

${ }^{7}$ ILO: Freedom of association and collective bargaining: General Survey, Report III (Part 4B), International Labour Conference, 81st Session, 1994, para. 118.

${ }^{8}$ See in particular, ILO: Stopping forced labour, Report of the Director-General, Report IB, International Labour Conference, 89th Session, Geneva, 2001.

9163 ratifications as at 12 Feb. 2004.

10161 ratifications as at 12 Feb. 2004.

${ }^{11}$ Concerned at the increase in trafficking of men, women and children for purposes of forced labour in areas such as domestic service, agriculture, factory work and the sex sector, the CEACR in 2001 adopted a general observation concerning labour trafficking under Convention No. 29. ILO: Report of the Committee of Experts on the Application of Conventions and Recommendations, Report III (Part 1A) [subsequently referred to as CEACR Report], International Labour Conference, 89th Session, Geneva, 2001, p. 119).
} 
expressed concern about the absence of penal sanctions or insufficient penal protection with respect to forced labour practices involving migrant workers. Such practices have included, for example, the use by employers of excessive power over migrant workers in an irregular situation, in particular domestic workers; the retention or non-payment of wages; contract substitution and retention of passports; long working hours and physical violence. ${ }^{12}$ The absence or inadequacy of measures taken, including legislation, against the trafficking of women and children into forced prostitution, or forced labour in agriculture abroad, also remain indications of the lack of commitment or institutional capacity to address the issue seriously.

\section{Elimination of child labour}

235. The elimination of child labour is covered by the Minimum Age Convention, 1973 (No. 138), ${ }^{13}$ and the Worst Forms of Child Labour Convention, 1999 (No. 182). ${ }^{14}$ Convention No. 138 prescribes specific age limits for the admission of children to work, including a prohibition on children under 18 years of age engaging in hazardous work. Convention No. 182 calls for "immediate and effective measures to secure the prohibition and elimination of the worst forms of child labour as a matter of urgency", and defines the worst forms of child labour as comprising: (a) slavery and forced labour, including child trafficking and forced recruitment for armed conflict; (b) child prostitution and pornography; (c) production and trafficking of drugs; and (d) work likely to harm the health, safety or morals of children. As to the exact types of work to be prohibited as hazardous work under category (d), the Convention leaves the matter to national determination after consultation with employers' and workers' organizations and taking into consideration relevant international standards. These instruments are backed up by the International Programme on the Elimination of Child Labour (IPEC). Problems related to work carried out by migrant worker children are being addressed in this context. Comments by the supervisory bodies on migrant child labour have mainly been issued under Convention No. 29 and relate to the lack of penal sanctions addressing practices such as the trafficking of children into prostitution, domestic service, agriculture and vending; the use of children as camel jockeys; and the forced labour of migrant children in plantations.

\section{Equality of opportunity and treatment}

236. The Discrimination (Employment and Occupation) Convention, 1958 (No. 111), ${ }^{15}$ requires ratifying States to declare and pursue a national policy aimed at promoting equality of opportunity and treatment and eliminating all forms of discrimination in employment and occupation based on race, colour, sex, religion, political opinion, national extraction and social origin. In addition, States parties to the Equal

\footnotetext{
12 See, inter alia, ILO: Report of the Committee on the Application of Standards, International Labour Conference, 88th-91st Sessions, Geneva, 2000-03.

13131 ratifications as at 12 Feb. 2004.

14147 ratifications as at 12 Feb. 2004. Convention No. 182 was adopted only recently, but both this Convention and Convention No. 138 have received a large number of new ratifications in the past few years. The ILO supervisory system is thus in the early stages of monitoring the implementation of these instruments in many countries of the world.

15159 ratifications as at 12 Feb. 2004.
} 
Remuneration Convention, 1951 (No. 100), ${ }^{16}$ have agreed to pursue a policy of equal remuneration for work of equal value between men and women workers.

237. The Conventions apply to nationals and non-nationals alike without distinction of status. Nationality is not listed among the grounds of discrimination formally prohibited by Convention No. 111. However, the supervisory bodies have frequently reaffirmed ${ }^{17}$ that migrant workers are protected by this instrument in so far as they are victims of discrimination in employment and occupation on the basis of any of the abovementioned prohibited grounds of discrimination. ${ }^{18}$ Concerning Convention No. 100, national migration studies and statistics have shown that wage discrepancies exist between male and female migrants, irrespective of their legal status. ${ }^{19}$

\section{Standards specifically concerning migrant workers}

\section{Comprehensive standards}

238. The ILO has developed standards specifically regarding migrant workers in two different political contexts: first, in 1949, in the aftermath of the Second World War and, second, in 1975, in the wake of the 1973 oil crisis.

239. The 1949 instruments were prompted, inter alia, by the interest in facilitating the movement of surplus labour from Europe to other parts of the world. The provisions of the Migration for Employment Convention (Revised), 1949 (No. 97), ${ }^{20}$ and the supplementing Migration for Employment Recommendation (Revised), 1949 (No. 86), focus on the standards applicable to the recruitment of migrants for employment and their conditions of work. By 1975 governments had become increasingly concerned about unemployment and the increase in irregular migration. The focus shifted from facilitating the migration of surplus labour to bringing migration flows under control. This caused the ILO to adopt two new standards: the Migrant Workers (Supplementary Provisions) Convention, 1975 (No. 143), ${ }^{21}$ and the Migrant Workers Recommendation, 1975 (No. 151). These instruments were the first multilateral attempt to deal with irregular migrants and also to call for sanctions against "traffickers". Convention No. 143 reiterates that member States have a general obligation to respect the basic human rights of all migrant workers. It also provides that migrant workers should not only be entitled to equal treatment (as provided for in Convention No. 97) but also to equality of opportunity, e.g. equality with regard to access to employment, ${ }^{22}$ trade union rights, cultural rights and individual and collective freedoms.

\footnotetext{
16161 ratifications as at 12 Feb. 2004.

${ }^{17}$ See, inter alia, CEACR Report, International Labour Conference, 89th Session, Geneva, 2001, individual observations concerning Conventions Nos. 97 and 111, pp. 369-374 and 493-495.

18 A proposal has been submitted to the ILO Governing Body to adopt a Protocol to Convention No. 111 that would allow member States to accept formally additional grounds on which discrimination would be prohibited and which would complement the ILO's protection against discrimination. The grounds proposed include nationality and state of health. The inclusion of a provision prohibiting discrimination on health grounds, including HIV/AIDS, would give additional force to the recently adopted ILO code of practice on HIV/AIDS and the world of work. See Governing Body, 289th Session, Geneva, March 2004, GB.289/2, paras. 8-15.

19 See Ch. 3, para. 134 (including references).

2042 ratifications as at 12 Feb. 2004.

2118 ratifications as at 12 Feb. 2004.

22 Recommendation No. 86 (supplementing Convention No. 97) already advocated equality of treatment between regular migrants and nationals with regard to admission to employment.
} 
240. Both Conventions Nos. 97 and 143 cover issues concerning the whole migratory process, including emigration, immigration and transit, and apply to persons who migrate from one country to another with a view to being employed otherwise than on their own account. With the exception of Article 8 of Convention No. 97 and to some extent Part II of Convention No. 143, the instruments do not make a distinction between permanent or non-permanent migrants. The provisions in these instruments do not depend on reciprocity and also cover refugees and displaced persons in so far as they are workers employed outside their home country. ${ }^{23}$ Both Conventions ${ }^{24}$ allow for exceptions from their scope of application, ${ }^{25}$ namely seamen, frontier workers, and artistes and members of the liberal professions who have entered the country on a shortterm basis. Convention No. 143 also excludes trainees and employees admitted temporarily to carry out specific duties or assignments ${ }^{26}$ from the coverage provided by the general provisions of Part II.

241. The ILO instruments advocate the development of model contracts to govern the situation of migrant workers. Such a solution is included in article 22 of the Model Agreement on Temporary and Permanent Migration for Employment, including Migration of Refugees and Displaced Persons, annexed to the Migration for Employment Recommendation (Revised), 1949 (No. 86), which also provides, inter alia, that bilateral agreements should include provisions concerning the equal treatment of migrants and nationals and appropriate arrangements for acquired rights in the area of social security.

242. Following its detailed examination in 1998 of the instruments relating to migrant workers, the CEACR concluded that the international context had changed and that there were certain lacunae in these standards. As examples of contextual changes, it cited the declining role of state leadership in the world of work; ${ }^{27}$ the feminization of migration for employment; the increase in temporary migration in place of migration for permanent settlement; the increase in illegal migration; and, finally, the development of certain means of transport. In this context, some of the provisions of Convention No. 97, including those regulating how to maintain migrant workers' health during ship transfers, appeared to have lost their purpose. Furthermore, the CEACR concluded that Conventions Nos. 97 and 143 did not deal with the elaboration and establishment of a national migration policy in consultation with employers' and workers' organizations, within the framework of overall national policy. ${ }^{28}$ Whether these lacunae are sufficiently important to require additional instruments is open to question.

243. In terms of problems in application and/or problems considered to be obstacles to ratification of the instruments, ${ }^{29}$ governments most frequently cited the following: concerning Convention No. 97: Article 6 (equality of treatment for foreign workers and nationals) and Article 8 (maintenance of residence rights for permanent migrant workers in the event of incapacity for work); and concerning Convention No. 143: Article 8

\footnotetext{
${ }^{23}$ General Survey, 1999, op. cit., para. 101.

${ }^{24}$ Under Article 11 of Convention No. 143, the named categories are excluded from the scope of Part II only.

25 See para. 251 below

26 See para. 281.

${ }^{27}$ Demonstrated, inter alia, by the increasing role of private recruitment agencies. See further para. 251 below.

28 See, however, Recommendation No. 151, Paragraph 1.

${ }^{29}$ In reports submitted for the General Survey, 1999.
} 
(protection for lawfully admitted migrant workers in the event of loss of employment), Article 10 (equality of opportunity and treatment), and Article 14(a) (right of migrant workers to geographical and occupational mobility). ${ }^{30}$

244. The CEACR also noted that certain difficulties in the application of Conventions Nos. 97 and 143 seemed to arise from misunderstandings of obligations in certain of their provisions.

\section{Social security}

245. Migrant workers are confronted with particular difficulties in the field of social security, as social security rights are usually related to periods of employment, contributions or residency. They run the risk of losing entitlements to social security benefits in their country of origin owing to their absence, and may at the same time encounter restrictive conditions in the host country with regard to their coverage by the national social security system. For migrant workers it is of particular importance to: (1) have the same access to coverage and entitlement to benefits as nationals; (2) maintain acquired rights when leaving the country (including the export of benefits); and (3) benefit from the accumulation of rights acquired in different countries. ${ }^{31}$

246. All current ILO social security standards define personal scope of coverage irrespective of nationality ${ }^{32}$ and almost all contain similar clauses on equality of treatment for nationals and foreign workers in the host country. However, the Equality of Treatment (Accident Compensation) Convention, 1925 (No. 19), ${ }^{33}$ specifically establishes the right to equality of treatment for foreign workers of any other State which has ratified the Convention, in respect of workmen's compensation for industrial accidents. The Equality of Treatment (Social Security) Convention, 1962 (No. 118), ${ }^{34}$ provides for the right to equality of treatment with regard to all nine branches of social security. For each of the nine branches that it accepts, a State party to the Convention undertakes to grant within its territory to nationals of any other State that has ratified the Convention equality of treatment with its own nationals. The provisions in both Conventions are thus dependent on reciprocity.

247. Other social security instruments also contain special non-discrimination clauses, for example, the Social Security (Minimum Standards) Convention, 1952 (No. 102). ${ }^{35}$ Part XI of this Convention is entirely devoted to equality of treatment of non-national residents. Article 68 of Convention No. 102, which applies to all branches of social security, provides that nationals and non-nationals should have the same rights to social

\footnotetext{
${ }^{30}$ In 2003, the types of obstacles cited were different but relatively few responses were recorded on this issue. See Annex I, section 3.1, for details.

31 Social security benefits are traditionally divided into nine different branches: medical care, sickness benefit, unemployment benefit, old-age benefit, employment injury benefit, family benefit, maternity benefit, invalidity benefit and survivors' benefit. For a detailed overview of ILO instruments on social security, see M. Humblet and R. Silva: Standards for the XXIst century - Social security, Geneva, ILO, 2002, pp. 41-45.

32 Their applicability to migrant workers is demonstrated, inter alia, by the fact that the ILO supervisory bodies have made specific reference to migrant workers in the context of their regular supervision: for example, with respect to application of the Employment Injury Benefits Convention, 1964 [Schedule I amended in 1980] (No. 121), and of the Medical Care and Sickness Benefits Convention, 1969 (No. 130).

33120 ratifications as at 12 Feb. 2004.

3438 ratifications as at 12 Feb. 2004.

3541 ratifications as at 12 Feb. 2004.
} 
security. It also provides, however, for some flexibility permitting exclusions of nonnationals in cases when benefits or parts of benefits are payable wholly out of public funds.

248. Convention No. 118 further provides for the maintenance of acquired rights and the export of benefits. In essence, a State party to Convention No. 118 has to ensure the provision of benefits abroad in a specific branch for its own nationals and for the nationals of any other State that has accepted the obligations of the Convention for the same branch, irrespective of the place of residence of the beneficiary. Convention No. 19 also provides for the export of benefits of foreign workers covered by the Convention, but only when the ratifying State provides for such export of benefits for its own nationals.

249. The Maintenance of Social Security Rights Convention, 1982 (No. 157), ${ }^{36}$ and Maintenance of Social Security Rights Recommendation, 1983 (No. 167), institute an international system for the maintenance of acquired rights and rights in the course of acquisition for workers who transfer their residence from one country to another, and which ensure the effective provision of the benefits abroad when they return to their country of origin. Under this Convention, the maintenance of acquired rights has to be ensured for the nationals of other States parties to the Convention in any branch of social security in which the States concerned have legislation in force. Within this context, the Convention provides for the conclusion of bilateral or multilateral social security agreements. In addition, the Recommendation contains model provisions for the conclusion of such agreements. Other social security Conventions, e.g. Convention No. 128, contain a specific clause for the maintenance of acquired rights.

250. For regular and longer-term migrant workers, equality of treatment between national and migrant workers in the country of employment with regard to existing social security benefits seems to be the rule. ${ }^{37}$ With regard to the export of benefits abroad, equality of treatment also seems to be the rule. However, possibilities for exporting benefits vary greatly depending on the country and the branch of social security in question. ${ }^{38}$ Restrictions on the export of benefits most often concern unemployment benefits. ${ }^{39}$ In most cases where migrant workers carry out work in different countries over a period of time, they are entitled to accumulate and maintain rights.

\section{Other relevant standards}

251. In addition to the fundamental principles and rights at work and the standards specific to migrant workers, all other ILO standards ${ }^{40}$ are also - in principle - applicable

\footnotetext{
363 ratifications as at $12 \mathrm{Feb} .2004$.

37 See Annex I, section 2.10, for details.

${ }^{38}$ Finland, for instance, allows both national and migrant workers the export of benefits but only with respect to long-term benefits (old-age benefit, employment injury benefit, invalidity benefit and survivors' benefit). Egypt, on the other hand, allows both national and migrant workers the export of benefits whatever the contingency may be.

39 With respect to this contingency, temporary migrant workers are thus at a comparative disadvantage.

40 The ILO has adopted a large number of instruments concerning seafarers. These instruments are in the process of being consolidated and a new instrument in this area will be considered at the 94th (Maritime) Session (2005) of the International Labour Conference. Given the discussion that will take place in 2005, these standards are not included in the scope of this report.
} 
to migrant workers. ${ }^{41}$ Some of them contain specific references to migrant workers. The application of certain instruments in practice is demonstrated, inter alia, by comments by the supervisory bodies of the ILO. Instruments that are of particular relevance for migrant workers, include the recent Safety and Health in Agriculture Convention, 2001 (No. 184). ${ }^{42}$ The Private Employment Agencies Convention, 1997 (No. 181), ${ }^{43}$ contains important provisions aimed at preventing abuses of migrant workers in relation to recruitment and placement through private employment agencies. This instrument reaffirms that the recruitment of migrant workers should be free of charge, but allows for exceptions in respect of certain categories of workers and specific types of services. ${ }^{44}$ This approach better conforms to the present realities, compared to the corresponding provisions contained in Convention No. 97, which only prescribes that services of employment agencies should be free. According to the Employment Promotion and Protection against Unemployment Convention, 1988 (No. 168), ${ }^{45}$ (lawfully resident) migrant workers should benefit from equal treatment and non-discrimination based, inter alia, on race, colour, sex, nationality or ethnic origin in the context of the promotion of full, productive and freely chosen employment.

252. The Protection of Wages Convention, 1949 (No. 95), ${ }^{46}$ is also relevant in this context and applies to all workers, without qualification. The CEACR has supervised its application in relation to migrant workers in the context of non-payment of wages to Egyptian workers forced to return to their country because of the Gulf War. ${ }^{47}$ Convention No. 95 also prohibits deductions from wages for payments to fee-charging agencies for the purpose of obtaining or retaining employment. ${ }^{48}$ This issue has been raised in the context of deductions made from the salaries of plantation workers, who are often migrants. ${ }^{49}$ In the context of the examination by the Working Party on Policy regarding the Revision of Standards in 1996, it was noted that the questions touching upon certain aspects of the payment of wages to migrant workers, in particular periodicity, modes of payment, deferred payments in foreign currency and appeals, were not adequately dealt with by the current provisions of Convention No. $95^{50}$ and that it

\footnotetext{
41 The Inter-American Court of Human Rights issued a sweeping opinion on 17 September 2003 which clearly reinforces the application of international labour standards to non-national workers, particularly those of irregular status. The Court found that non-discrimination and the right to equality are "jus cogens" and applicable to all residents regardless of immigration status.

42 Three ratifications as at $12 \mathrm{Feb}$. 2004. Information on the practical application of this instrument is not yet available as it is a recently adopted instrument. Regarding its relevance in this context, see "Migrant workers in agriculture", paras. 276-278 below.

4314 ratifications as at 12 Feb. 2004.

${ }^{44}$ See also Annex I, section 2.8 .

456 ratifications as at 12 Feb. 2004.

4695 ratifications as at 12 Feb. 2004.

47 CEACR Report, International Labour Conference, 89th Session, Geneva, 2001, p. 358.

48 ILO: Protection of wages: Standards and safeguards relating to the payment of labour remuneration, General Survey of the reports concerning the Protection of Wages Convention, 1949 (No. 95), and the Protection of Wages Recommendation, 1949 (No. 85), Report III (Part 1B), International Labour Conference, 91st Session, Geneva, 2003, para. 267.

49 CEACR Report, International Labour Conference, 87th Session, Geneva, 1999, p. 313, and CEACR Report, International Labour Conference, 89th Session, Geneva, 2001, p. 357. Certain forms of deductions have been considered to amount to debt bondage, which constitutes a form of forced labour. See para. 234 above. See also Stopping forced labour, op. cit., para. 63.

${ }^{50}$ Convention No. 95 is nevertheless included among the 71 up-to-date Conventions.
} 
would be desirable to examine the question of deductions from wages for the services provided by private employment agencies. ${ }^{51}$ The Working Conditions (Hotels and Restaurants) Convention, 1991 (No. 172), ${ }^{52}$ is also an important instrument for migrant workers, who are frequently employed in this sector. States parties thereto undertake to pursue a policy to ensure that the workers concerned are not excluded from the scope of any minimum standards adopted at the national level. This instrument has so far only been ratified by a handful of countries, however, and the question of migrant workers has not yet been raised in the context of its supervision.

253. The CEACR has also considered other standards to be relevant for migrant workers including the following up-to-date standards: the Labour Inspection Convention, 1947 (No. 81), ${ }^{53}$ the Labour Inspection (Agriculture) Convention, 1969 (No. 129), ${ }^{54}$ the Labour Clauses (Public Contracts) Convention, 1949 (No. 94), ${ }^{55}$ the Plantations Convention, 1958 (No. 110), ${ }^{56}$ and the Employment Policy Convention, 1964 (No. 122) ${ }^{57}$ In terms of their content, the following up-to-date instruments also seem to be relevant in this context, although the CEACR has not yet had the opportunity to make specific comments on their application in relation to migrant workers: the Minimum Wage Fixing Convention, 1970 (No. 131), ${ }^{58}$ the Nursing Personnel Convention, 1977 (No. 149), ${ }^{59}$ the Occupational Safety and Health Convention, 1981 (No. 155), ${ }^{60}$ and the Occupational Health Services Convention, 1985 (No. 161), ${ }^{61}$ the Safety and Health in Construction Convention, 1988 (No. 167), ${ }^{62}$ and the Workers' Housing Recommendation, 1961 (No. 115).

254. In some cases, on the other hand, flexibility clauses in instruments may permit certain branches of activity or categories of workers to be excluded from coverage. These may be branches or activities where migrant workers are traditionally employed. In practice, member States have most often excluded domestic ${ }^{63}$ and agricultural

\footnotetext{
${ }^{51}$ See GB.267/LILS/WP/PRS/2, section III.4.

5213 ratifications as at 12 Feb. 2004.

53130 ratifications as at $12 \mathrm{Feb}$. 2004. The CEACR has, inter alia, requested States parties to this Convention to report on the level of resources attributed to labour inspectorates and whether they are adequate to deal with the supervision of migrant workers and on how reliable statistics are gathered, in particular regarding occupational diseases with long latency periods to which migrating workers might be exposed. (CEACR Report, International Labour Conference, 90th Session, Geneva, 2002, p. 233.)

5441 ratifications as at 12 Feb. 2004.

5559 ratifications as at 12 Feb. 2004.

5612 ratifications as at $12 \mathrm{Feb} .2004$

5794 ratifications as at 12 Feb. 2004. Regarding employment policy, see also Employment Policy Recommendation, 1964 (No. 122), and Employment Policy (Supplementary Provisions) Recommendation, 1984 (No. 169).

5845 ratifications as at 12 Feb. 2004.

5937 ratifications as at 12 Feb. 2004.

${ }^{60} 41$ ratifications as at $12 \mathrm{Feb} .2004$

6122 ratifications as at 12 Feb. 2004.

6217 ratifications as at 12 Feb. 2004.

${ }^{63}$ Such exclusions concern in particular the following instruments: Convention No. 95 (protection of wages), Convention No. 131 (minimum wage), Convention No. 148 (working environment), Convention No. 162 (asbestos), Convention No. 171 (night work), and Convention No. 175 (part-time work).
} 
workers ${ }^{64}$ when such exclusions have been used. But these are generally not very frequent. Although Convention No. 184 permits the exclusion of certain categories of agricultural workers, it specifically covers temporary and seasonal workers who are often migrant workers. No specific standards have been adopted with respect to domestic workers.

\section{Instruments developed by the United Nations}

\section{Instrument specifically concerning migrant workers}

255. In 1990 the United Nations adopted a comprehensive instrument regulating most aspects of international migration: the International Convention on the Protection of the Rights of All Migrant Workers and Members of Their Families ("the United Nations Convention"), which recently entered into force. ${ }^{65}$ The ILO and United Nations instruments specifically concerned with migrant workers have similar overall aims: to further the rights and protections of persons migrating for employment and to discourage and eventually eliminate irregular migration. The United Nations Convention's definition of "migrant worker" is broader than that of the ILO Conventions (the United Nations Convention covers frontier workers, seafarers and the self-employed), and the definition of "family" in the United Nations Convention is also broader than the definition in the ILO Conventions.

256. In terms of substantive coverage, Part III of the United Nations Convention enumerates the civil, political, economic, social and cultural rights applicable to all migrant workers and members of their families irrespective of whether they are documented or non-documented. These provisions are mostly specific formulations of the applicability of universal human rights to migrants as elaborated in the instruments of the Universal Declaration of Human Rights and the International Covenant on Civil and Political Rights. As with United Nations Conventions relating to the rights of women, children and victims of racism, this Convention sought to extend protection of universal rights to vulnerable groups by providing explicit normative language suitable for national legislation. Compared to the specific ILO instruments, the United Nations Convention seems to provide for a broader articulation of the principle of equality of treatment between migrant workers and nationals before the courts and tribunals, with respect to remuneration and other working conditions as well as with respect to migrant workers' access to urgent medical assistance and education for children of migrant workers. Compared to the ILO instruments the United Nations Convention also seems to provide for more extensive rights for migrant workers to transfer their earnings and savings. In terms of the right to reimbursement of social security contributions, however, the ILO instruments (including specific Conventions on social security) define migrant workers' rights more clearly. As regards additional rights from which documented migrants and members of their families may benefit (Part IV of the United Nations Convention), the ILO and United Nations instruments are quite similar, except that the ILO Conventions provide for more distinct rights for migrant workers to form a trade union, and the right to equal treatment in terms of access to education, housing and

\footnotetext{
${ }^{64}$ Such exclusions concern in particular the following instruments: Convention No. 14 (weekly rest); Convention No. 78 (medical examination of young persons); Convention No. 95 (protection of wages); Convention No. 131 (minimum wage); Convention No. 138 (minimum age); Convention No. 148 (working environment); Convention No. 171 (night work); Convention No. 175 (part-time work); and Convention No. 184 (OSH in agriculture).

65 The Convention entered into force on 1 July 2003, and had a total of 25 ratifications as at 12 Feb. 2004.
} 
vocational and social services. Finally, under the United Nations Convention, migrant workers may benefit from a clearer level of protection in relation to expulsion.

257. The ILO instruments (in particular Convention No. 143) and the United Nations Convention (Part VI) both place great emphasis on efforts to curb irregular migration and the need to formulate appropriate migration policies to that effect; and on exchanging information, providing information to migrant workers, and facilitating the provision of consular services and the imposition of sanctions to give effect to regulations in this area.

\section{Box 4.1 \\ Commission on Human Security - A proposal for an international migration framework}

The Commission on Human Security proposes the development of an international migration framework which, among other issues, would address:

a Taking steps towards the orderly and safe movement of people, including increasing migratory opportunities and burden-sharing among countries.

a Developing international and regional norms for the movement of people between countries and for the rights and obligations of migrants.

- Formulating strategies to combat trafficking and smuggling and implementing the relevant international and regional conventions, while protecting the rights of victims.

a Protecting against racism and intolerance and other human rights violations.

口 Developing an institutional framework.

Source: Commission on Human Security, Human Security Now, New York, 2003, p. 47.

\section{Other relevant United Nations instruments}

258. The United Nations Universal Declaration of Human Rights, adopted in 1948, states that all individuals, irrespective of race, colour, sex, language, religion, political or other opinion, national or social origin, property, birth or other status, are born free and equal in dignity and rights. In addition, several other United Nations instruments are relevant for protecting migrant workers from discrimination and exploitation on grounds other than their non-national status, including the International Convention on the Elimination of All Forms of Racial Discrimination (ICERD), 1965. This is currently one of the most widely ratified of the United Nations human rights Conventions, ${ }^{66}$ and while it binds States parties to outlaw discrimination on the grounds of race, colour, descent, or national or ethnic origin against all individuals within the jurisdiction of the State and to enact sanctions for activities based upon such discrimination, it does not apply to discrimination on the grounds of nationality, a type of discrimination to which migrants by definition are extremely vulnerable.

259. The Convention on the Elimination of All Forms of Discrimination Against Women (CEDAW), 1979, consolidates the provisions of existing United Nations instruments concerning gender discrimination. The Convention applies to citizens and non-citizens and provides that States parties shall take all appropriate measures to eliminate discrimination against women in the field of employment in order to ensure the same rights, on the basis of equality between men and women. CEDAW is specifically relevant to migrant workers in that it requires States parties to take all appropriate

66169 ratifications as at 1 Feb. 2004. 
measures, including legislation, to suppress all forms of traffic in women and exploitation of prostitution of women. Other human rights instruments of relevance to migrant workers include the International Covenant on Economic, Social and Cultural Rights (1966), the International Covenant on Civil and Political Rights (1966), the Convention against Torture and Other Cruel, Inhuman or Degrading Treatment or Punishment (1984), and the Convention on the Rights of the Child (1989). All these instruments, like the ILO's general human rights instruments, apply to all persons.

260. Transnational organized crime, including trafficking and smuggling, has recently been addressed in the context of the newly adopted Convention against Transnational Organized Crime. Labour trafficking and smuggling ${ }^{67}$ were regulated separately in two protocols supplementing this convention which were also adopted in 2000 and which both recently entered into force: the Protocol to Prevent, Suppress and Punish Trafficking in Persons, Especially Women and Children (Trafficking Protocol) and the Protocol against Smuggling of Migrants by Land, Sea and Air (Smuggling Protocol).

\section{Instruments developed by the WTO}

261. As already mentioned in Chapter 2, the WTO has also developed an important set of international provisions governing migration, which include some requirements individuals have to fulfil in order to move and work abroad. Although it only accounts for just over 1 per cent of world services trade so far, ${ }^{68}$ the presence of natural persons, otherwise referred to as Mode 4, is one of the four possible forms of providing a service under the General Agreement on Trade in Services (GATS). Members' commitments under this "mode" refer to the temporary admission of foreign natural persons as service providers into their territory (e.g. accountants, doctors, nurses, teachers). Permanent migration is not covered under Mode 4.

\section{Regional agreements}

262. Regional and subregional bodies also include the management of international migratory flows as a main issue in their agendas and have developed a wide range of measures at different levels concerning the conditions of admission, stay and treatment of non-national workers. Regional standards include standards dealing with the protection of migrant workers as well as standards which relate to the management of migration. Within Europe there is an elaborate set of labour migration standards, particularly at the level of the European Union. In this respect, the entry into force in 1999 of the Treaty on European Union as amended by the Treaty of Amsterdam represents a turning point in the European Union's commitment with regard to immigration and moves the development of a migration policy from the intergovernmental level to the community level.

263. Processes of regional economic integration are also taking place on all other continents. The 1999 General Survey on migrant workers has already highlighted the fact that initiatives in the field of labour mobility revealed a series of converging

\footnotetext{
${ }^{67}$ Smuggling of migrants involves migrants who have consented to the smuggling, whereas trafficking victims have either never consented or, if they initially consented, that consent has been rendered meaningless by the coercive, deceptive or abusive actions of the traffickers. Other differences include the fact that smuggling ends with the arrival of migrants of their destination while trafficking involves ongoing or further exploitation. In addition, smuggling always require a border crossing while trafficking can take place within a country.

${ }^{68}$ These data are based on recent estimates reported by the WTO Secretariat (Joint WTO-World Bank Symposium on Movement of Natural Persons (Mode 4) under the GATS, WTO, Geneva, 11-12 April 2002).
} 
interests towards progressive harmonization at regional and subregional levels. ${ }^{69}$ For instance, in the last few years, an increasing number of regional inter-State economic integration spaces/processes have established or renewed efforts to implement formal legal and administrative agreements regarding labour circulation. The Andean Community adopted in 2003 a revised Andean Instrument for Labour Migration. In order to strengthen the integration process, Mercosur countries approved an agreement on residence for their nationals in November 2002. The Treaty formalizing the East African Community, which entered into force in 2003 among the three member States, establishes free circulation and residence of labour for nationals of member countries. The Central African Economic and Monetary Community (CEMAC) agreed in 2003 to establish new measures to put into effect its accord on free circulation of labour, which was adopted in the 1980s but never effectively implemented. The Southern Africa Development Community (SADC) drafted a Protocol in 2001 on free movement of labour; although ultimately it was not adopted by States, new initiatives to address labour migration among the 14 member States are currently being negotiated. ${ }^{70}$

264. A few of these formal agreements or proposals draw on relevant international standards, in particular ILO Conventions Nos. 97 and 143, which have been ratified by some member States of these regional entities. Several, however, have not drawn on the experience incorporated in international standards, with the risk both of repeating mistakes these standards were designed to avoid and of putting in place legal measures which undermine existing norms.

\section{Bilateral agreements}

265. Convention No. 97 includes a general invitation to enter into bilateral agreements, whenever necessary or desirable, to regulate relevant issues related to migration in connection with the application of the Convention, and proposes the use of a model agreement appended to its accompanying Recommendation No. 86. This model agreement covers most aspects of the migratory process and also includes proposed contents for model contracts of employment.

266. Although not a comprehensive solution to all the issues concerned, the conclusion of bilateral agreements is a useful solution to provide for better protection of migrant workers in particular with respect to certain areas, such as social security, or with regard to more vulnerable categories of migrant workers.

267. In practice, bilateral agreements have been a longstanding means of resolving and managing migration flows between two countries. This was current practice until the global economic downturn in the 1970s. Since then, a large number of these agreements have lapsed and been replaced by much looser framework agreements, memoranda of understanding and declarations of mutual cooperation on the contracting and protection of foreign workers. ${ }^{71}$ Since the 1990 s, there has been a global upsurge in bilateral

\footnotetext{
${ }^{69}$ See in particular paras. $62-74$.

${ }^{70}$ For more on this issue, see Ch. VI (Managing migration).

71 M. Abella: Sending workers abroad (Geneva, ILO, 1997).
} 
agreements, although the practice varies in different regions. ${ }^{72}$ These bilateral agreements may have a wide range of objectives including specifically preventing a rise in illegal migration or seeking to address broader economic and social issues. ${ }^{73}$ Others specifically address issues related to seasonal work in agriculture. ${ }^{74}$

268. As in the case of regional agreements, it is important that bilateral agreements operate within a multilateral context of international standards and that the bilateral and multilateral levels are mutually supportive.

\subsection{Relevance and impact of international regulation}

\section{Current situation}

269. It follows from this review that the ILO has, in principle, a functioning regulatory system with respect to international migration and the protection of migrant workers. In spite of the changes in the context of international migration and the lacunae identified by the CEACR - including the fact that the ILO Conventions on migrant workers do not specifically prescribe the development of a national migration policy ${ }^{75}$ - the principles enshrined in these instruments still provide sound guidance on the protection of migrant workers and measures to facilitate and control migration movements. More specifically, they call for measures aimed at regulating the conditions in which migration for employment occurs, and for measures aimed at combating irregular migration, as well as containing provisions on cooperation between States. They define parameters for recruitment and contract conditions, participation of migrants in job training and promotion, and, to a certain extent, for family reunification and appeals against unjustified termination of employment or expulsion. A number of provisions in the ILO instruments on migrant workers are intended to provide a framework for guaranteeing

\footnotetext{
72 In Latin America the number of bilateral agreements has doubled over the past decade, but countries in Asia (with the exception of the Philippines) seem to have a greater resistance towards such agreements (see IOM: World Migration 2003). In the OECD countries, there are currently 173 bilateral agreements with countries from all regions of the world, which represents a fivefold increase since the 1990s. (OECD: Bilateral labour agreements: Evaluation and prospects, Seminar on Bilateral Labour Agreements jointly organized by the OECD and the Swiss Government, Montreux, June 2003). The ILM Survey also indicates considerable use of bilateral agreements by Central and Eastern European States and by the Commonwealth of Independent States, not only between States in the region or with neighbouring States of the European Union, but with countries of southern Europe such as Spain and Portugal and even with countries on other continents. See also Annex I, section 2.6.

73 This is the case with the agreements that Argentina has concluded with Bolivia (1999), Peru (1999) and Paraguay (not yet in force).

74 These include the successful experience with the Commonwealth Caribbean and Mexican Agricultural Seasonal Workers Programme in Canada. This is often considered a model programme for admitting and protecting migrants (P. Martin: Managing labour migration: Temporary worker programmes for the 21 st century. Geneva, International Institute for Labour Studies, 2003). It is based on an MOU that calls for the Mexican Government to select workers and monitor their conditions in Canada, and a Canadian farm employers' association to transport them to the farms on which they work. Farm employers provide written evaluations of each worker at the end of the season, with evaluations placed in sealed envelopes and delivered by returning workers to the Mexican authorities. Some unions are critical of this evaluation system, alleging that workers who protest are not invited to return: 70 per cent of Mexican migrants are requested by name by their employers. Most Mexican migrants report that they prefer the security of contracts in Canada to the insecurity of unauthorized status in the United States, but some Canadian unions and NGOs consider the migrants "unfree" because they can be blacklisted. Nevertheless, the Canadian arrangement seems to be one that is free of the common problems that beset temporary worker programmes.

${ }^{75}$ However, 59 of the 90 responding countries have declared that, in practice, they have adopted such a policy. See Annex I, section 2.1, for details.
} 
protection of migrant workers. They relate to the minimum standards of protection; the provision of correct information about conditions in the country of employment; measures to facilitate the adaptation of migrants to living and working conditions in the country of employment; special provisions on mechanisms for the transfer of migrants' earnings; employment opportunities; and access to social services, medical services and reasonable housing. In addition, the provisions in Convention No. 143 call for the adoption of a policy to promote and guarantee equality of treatment and opportunity between regular-status migrants and nationals in employment and occupation in the areas of access to employment remuneration, social security, trade union rights, cultural rights and individual freedoms, employment taxes and access to legal proceedings.

270. Since the 1999 Survey, and in the context of the regular reporting on the application of Conventions Nos. 97 and 143, the CEACR has raised a number of questions on developments in national law and practice as regards irregular migrants, procedural guarantees for foreigners, control of expulsion procedures, the place of women in labour migration, and respect for fundamental rights. In addition, the question of wage discrimination ${ }^{76}$ against domestic workers has become an important issue in the context of a representation concerning the application of Convention No. 97.

271. In the context of the 2003 ILM Survey, member States were also asked to indicate their views on the existence of gaps in existing standards and the way ahead for future ILO action in this area. Relatively few responses were received on these questions. ${ }^{77}$ The responses received were difficult to interpret. Concerns raised regarding gaps ${ }^{78}$ including lacunae in the protection of irregular migrant workers, temporary migrant workers and domestic migrant workers, as well as in the social protection of migrant workers - did not necessarily imply that a recommendation was made for ILO action. Among the 23 countries that proposed action, a majority proposed a revision of existing standards, but proposals were also made to develop a new Convention and/or Recommendation. In a handful of cases, several or all of these actions were proposed simultaneously. Proposals were also made to develop codes of practice and/or guidelines. As regards the specific concerns that such ILO action should address, 11 different areas were identified, by a similar number of countries. In no case were any of these specific concerns proposed by more than two member States.

\section{Protecting the rights of specific groups of migrant workers}

272. It follows, however, from the overview in preceding chapters of this report, that in spite of existing regulation of international migration and the protection of migrant workers, the situation of certain specific groups of migrant workers remains a cause of serious concern. The protection provided in current standards for these specific groups of migrant workers is examined below.

\section{Migrant domestic workers}

273. One of the manifestations of the feminization of migration has been the increase in the number of women engaging in domestic work as regular migrant workers but also often as irregular migrants. Domestic work is an area that is characterized by a particular

\footnotetext{
${ }^{76}$ For details, see forthcoming CEACR Report, International Labour Conference, 92nd Session, Geneva, 2004.

77 Approximately one-third of the respondents. See Annex I, section 3.1, questions 43 and 44, for details.

${ }^{78}$ Half of the 29 respondents on this issue considered there were gaps, while the other half found that there were none.
} 
absence of regulatory systems. At the international level, the flexibility of international standards may be used to exclude this type of work from their scope. ${ }^{79}$ At the national level, domestic work is often excluded from the scope of national labour and/or other laws. There may thus be cases where domestic migrant workers are only protected by generally applicable fundamental principles and rights and basic human rights. But, as with migrant workers in an irregular situation, the crucial issue in these cases is whether domestic workers have effective access to appeals procedures and/or to other institutions such as independent human rights commissions or similar bodies, in order to be able to claim their rights to protection. ${ }^{80}$

274. The ILO's approach to these issues had been geared towards prevention by regulating the recruitment process, and the use of model contracts incorporating basic issues such as salary, hours of work and weekly rest. There are some good practices observed in this respect. For example, one country ${ }^{81}$ has adopted a model contract for domestic workers and has established a "hot line" to receive complaints from domestic workers. Another country ${ }^{82}$ has included in a model contract entitlements to life insurance, medical care, rest days, repatriation upon expiration of the contract, and reiterates migrant women's right to be treated in compliance with international human rights standards. ${ }^{83}$ Other countries also use model contracts in relation to particularly vulnerable occupations such as domestic work, manual labour and agricultural work. ${ }^{84}$

275. Furthermore, as noted previously, the conclusion of bilateral agreements may be a particularly useful tool to protect this category of migrant workers. It is a matter of debate whether this gap concerning migrant domestic workers should be filled at the international level, or more generally by encouraging wider dissemination of the practice in certain countries of providing protection for domestic workers in their national labour legislation.

\section{Migrant workers in agriculture}

276. Many workers in agriculture in a large number of countries are migrant workers. The protection of workers in the agricultural sector has long been a concern for the ILO, and there are several standards which apply to agricultural workers in general. ${ }^{85}$ Two of these instruments are particularly relevant for migrant workers: Convention No. 110, including its Protocol of 1982, and Convention No. 184. Although Convention No. 110

\footnotetext{
79 See para. 254.

${ }^{80}$ A number of countries are establishing or have established specialized bodies with advisory or quasi-judicial powers to tackle discrimination and promote equality. At the national level there are several initiatives in this respect, including bodies with quasi-judicial powers to examine complaints on human rights violations or discrimination in a wide number of areas in countries such as Austria, Brazil, Hong Kong (China), Trinidad and Tobago and the United States. Bahrain has established a Human Rights Commission, which is looking into domestic worker issues as well. Finally, it is worth mentioning that some countries such as Hungary, Norway and Sweden have established ombudsperson offices or ombudsperson-type offices that may receive complaints and institute proceedings before court.

81 Hong Kong, China.

82 Jordan.

${ }^{83}$ Press release by the United Nations Development Fund for Women (UNIFEM), Arab States Regional Office, Amman, 21 Jan. 2003.

${ }^{84}$ Sri Lanka and United Republic of Tanzania.

${ }^{85}$ See ILO: Decent work in agriculture, Background paper for the Symposium on Decent Work in Agriculture, Geneva 15-18 September 2003, Appendix: "ILO Conventions and Recommendations relevant to agriculture".
} 
has received only a handful of ratifications, it is a comprehensive instrument covering a wide range of relevant issues. However, the Convention offers considerable flexibility for ratifying parties as several of its parts can be excluded, including the part concerning the engagement and recruitment of migrant workers.

277. Convention No. 184 focuses specifically on occupational safety and health, which - as the statistics concerning occupational accidents demonstrate - is an issue of major concern in agriculture. Convention No. 184 specifically provides that "measures shall be taken to ensure that temporary and seasonal workers receive the same safety and health protection as that accorded to comparable permanent workers in agriculture" and that "adequate and appropriate training and comprehensible instructions on safety and health and any necessary guidance or supervision are provided to workers in agriculture ... taking into account their level of education and differences in language." As noted above, Convention No. 184 also provides more generally that relevant national laws and regulations on welfare and accommodation facilities, working time arrangements and coverage against occupational injuries and diseases should apply to workers in agriculture.

278. In addition, and as with the case of domestic workers, the ILO standard-setting approach has been to advocate the conclusion of model contracts and bilateral agreements. In practice, there are quite a few examples of such bilateral agreements. ${ }^{86}$

\section{Migrant workers in construction}

279. The surge in subcontracting and a high level of privatization has had profound effects on the labour market generally, and construction is a sector particularly marked by this trend. In this respect, the ILO is in the process of addressing the more general problem of the employment relationship. A general discussion has recently been held on this issue resulting in a decision that the ILO should envisage the adoption of a Recommendation in this area. ${ }^{87}$

280. In terms of specific problems, construction is a sector with one of the highest incidences of occupational accidents and the ILO has adopted several instruments of general relevance in this area, as well as a Convention and a Recommendation specifically dealing with occupational safety and health in construction - Convention No. 167 and Recommendation No. 175. This Convention provides that the term "employer" includes any physical or legal person who employs one or more workers on a construction site; and includes, as the context requires, the principal contractor, the contractor or the subcontractor. This standard appears to be particularly relevant to migrant workers and is applicable to them, but the CEACR has not yet had the opportunity to address the conditions of migrant workers in this context.

281. Although the problems in the construction industry particularly affect migrant workers owing to the high number of migrant workers employed there, the difficulties they face appear to be largely due to more general issues of global concern. Moreover,

\footnotetext{
${ }^{86}$ Such as the agreements Canada has entered into with Mexico, Jamaica, Trinidad and Tobago, Barbados and the Organization of Eastern Caribbean States; France with Poland, Morocco and Tunisia; Germany with several Eastern European states; Greece with Albania; Italy with Tunisia; and Albania and Spain with Poland. In addition, there is a recent agreement between Kazakhstan and Kyrgyzstan.

${ }^{87}$ ILO: Report of the Committee on the Employment Relationship, International Labour Conference, 91st Session (2003), Conclusions, para. 25. A corresponding proposal to include such an item at a future Conference has been submitted to the Governing Body, see doc. GB.289/2.
} 
migrant workers in this sector may be particularly affected by the problems relating to temporary migrant workers addressed below.

\section{Temporary migrant workers}

282. Current ILO standards were not drafted with the protection of temporary migrant workers in mind and the provisions applicable to other lawfully admitted migrant workers may not always be well suited to their situation. ${ }^{88}$ Like other lawfully admitted migrant workers, temporary migrant workers enjoy the protection of the fundamental principles and rights and are entitled to benefit from the provisions in Convention No. 97 concerning equal treatment.

283. While Part II of Convention No. 143 provides for equality of opportunity and treatment for all lawfully admitted residents, Article 11 excludes certain specific categories of temporary migrant workers from the scope of this Part. ${ }^{89}$ Article 11(2)(e), excludes "employees of organisations or undertakings operating within the territory of a country who have been admitted temporarily to that country at the request of their employer to undertake specific duties or assignments, for a limited and defined period of time, and who are required to leave the country on the completion of their duties or assignments." In the preparatory work preceding the adoption of Convention No. 143, it was stressed that this provision applied essentially to workers having special skills who go to a country to undertake specific short-term technical assignments. Although the CEACR recalled that the provision did not imply that all fixed-term workers could be excluded from the provisions of Part II of Convention No. $143,{ }^{90}$ this question may need further examination taking account of the increase in temporary migration and GATS Mode 4.

284. Another exclusion provided for in Article 11 of Convention No. 143 concerns "artistes and members of the liberal professions who have entered the country on a shortterm basis". In 1999 the CEACR noted that this exclusion had taken on a vastly increased significance, particularly in relation to the increasing number of female migrant workers recruited for employment abroad and issued permits to work as dancers in night clubs or as hostesses in bars, when in reality they are forced to become "sex workers." ${ }^{91}$ There are several indications that this development has continued and increased in proportions since then. This category of workers is addressed in particular by the new international standards on trafficking.

285. Furthermore, Article 8 of Convention No. 97 grants only permanently admitted migrants the specific right not to be forced to return, if they are unable to work owing to illness or injury.

286. Subject thereto, Convention No. 143 applies equally to lawfully admitted temporary and other migrant workers, although temporary migrant workers' rights to

\footnotetext{
88 This was discussed at a Tripartite Meeting of Experts on Future ILO activities in the Field of Migration (21-25 April 1997), which resulted in the adoption of the Guidelines on special protective measures for migrant workers in time-bound activities (MEIM/1997/D.4, Annex I). These guidelines covered issues such as accommodation, tied employment, wages and other terms of employment, family migration and reunification, freedom of association, social security and return. The Office does not have any information on the impact of these guidelines.

89 Recommendation No. 151 does not, however, contain any similar exclusions.

${ }^{90}$ General Survey, 1999, para. 115 (including references).

${ }^{91}$ General Survey, 1999, para. 113.
} 
equal treatment in the case of loss of employment is limited to the duration of their residence or work permit. In other words, this means that temporary migrant workers who lose their employment are entitled to look for new employment opportunities as long as they remain lawfully resident, i.e. for the remainder of their work or residence permit. ${ }^{92}$ Practice in this respect varies, but several countries seem to allow temporary migrant workers to seek alternative employment for the duration of their residence permit. ${ }^{93}$

287. In terms of social security, the relevant instruments make no distinction between temporary and other regular migrant workers. Residence requirements may, however, hamper temporary migrant workers' possibilities of acquiring benefits. As regards the maintenance of acquired rights when leaving the country (including the export of benefits), and the right to benefit from the accumulation of rights acquired in different countries, current standards provide for such entitlements but they are limited by the principle of reciprocity. Social security issues are often the subject of bilateral or multilateral agreements as recommended by ILO standards. ${ }^{94}$ In some cases, and in the absence of bilateral or multilateral agreements, migrant workers who leave the country are granted a refund of the contributions which they have paid for long-term benefits.

288. Current ILO Conventions do not regulate the question of access to public health care, but according to Recommendation No. 151 migrant workers lawfully residing in a country should also be entitled to equality of opportunity and treatment with nationals in respect of the benefits of social services and educational and health facilities.

289. Finally, as noted previously, Convention No. 143 together with Recommendations Nos. 86 and 151 and the United Nations Convention contain largely similar conditional provisions concerning the right of migrant workers to be united with their families, but the United Nations Convention defines the concept of "family" more broadly than the ILO Conventions. ${ }^{95}$ Most temporary labour schemes do not permit migrant workers to be accompanied by their family members. The ILO supervisory bodies have noted that in some cases of temporary, seasonal or project-related work, family reunification may be inappropriate for practical reasons, but the individual circumstances of each case should be taken into consideration.

\section{Migrant workers in an irregular situation}

290. While Convention No. 97, Recommendation No. 86 and Part II of Convention No. 143 deal only with the protection of migrant workers who have been regularly admitted for the purpose of employment, Part I of Convention No. 143 and several provisions of Recommendation No. 151 deal explicitly with the suppression of clandestine migration flows and the protection of migrants of irregular status. It is worth recalling here that any member State that ratifies this Convention may exclude either Part I or Part II from its acceptance of the Convention.

\footnotetext{
92 Prior to the clarifications provided by the CEACR in the 1999 General Survey, a common misunderstanding of these provisions was that Convention No. 143 would prevent States from requiring temporary migrant workers to return at the end of their contracts. Relevant CEACR practice clarifies that this is not the case.

93 See Annex I, section 2.12, for details.

${ }^{94}$ For further information on bilateral social security agreements, see: http://www.ilo.org/public/english/protection/ socsec/pol/publ/index.htm .

${ }^{95}$ It should be emphasized, however, that all these instruments stipulate only that family reunification should be "facilitated".
} 
291. According to Article 1 of Convention No. 143, ratifying States undertake to protect the basic human rights of "all migrant workers". In this respect, the structure of Convention No. 143 is similar to that of the United Nations Convention in the sense that the latter refers in Part III to the "Human rights of all migrants workers and members of their families", whereas other rights listed in Part IV concern "migrant workers and members of their families who are documented or in a regular situation".

292. As regards social security benefits, the relevant ILO social security instruments have nothing to say with regard to the protection of migrant workers in an irregular situation. The same applies with respect to other international instruments that deal with migrant workers in an irregular situation and with social security. One exception, however, can be found in Convention No. 143, which stipulates that migrant workers in an irregular situation shall have the same rights as regular migrant workers concerning social security rights arising out of past employment. This provision must in particular be understood for the purpose of acquiring rights to long-term benefits. Within this context, it appears from the General Survey on migrant workers that the wording "past employment" refers to past periods of legal as well as illegal employment. Paragraph 34(1)(b) of Recommendation No. 151, which accompanies Convention No. 143, recommends that migrant workers, irrespective of their legal status, who leave the country of employment should be entitled to benefits which may be due in respect of any employment injury suffered. ${ }^{96}$

293. With respect to expulsion, the supervisory bodies have laid particular emphasis on respect for the provision in Convention No. 143 that the costs of expulsion should not be borne by the worker. There is an even more important question in practice as to whether guarantees are in place concerning respect for the fundamental and basic human rights of migrant workers in the context of expulsion, and whether they have effective recourse to appeal against such decisions.

294. While one can still argue about the content of substantive rights and how far these rights may be applied in practical terms to irregular migrants, there is a clear need to promote better application of labour standards to all migrant workers. It should be clear that the obligation of all States to protect the basic human rights of all persons resident within their territory and regardless of the regularity of their status should not be challenged. Also, it cannot be overemphasized that the protection of the rights of migrant workers in an irregular situation is illusory if difficulties bar their access to appeal procedures. This is particularly true in cases where immigration law and practice are in conflict with national labour law.

\footnotetext{
${ }^{96}$ In practice, most countries provide that social security benefits are dependent on legal employment or residence in the country (as in France, for example) or on holding a valid work permit (as is the case in Lebanon and the United Kingdom), but others (Luxembourg and Norway, for example - see CEACR 1980 General Survey on migrant workers) consider that the legal status of migrant workers is irrelevant in this respect. Some seem most inclined to allow irregular migrants to benefit from protection only against occupational accidents and diseases. In one particular case (Belgium), the legislation governing employment injury compensation was a matter of public policy and hence mandatory: the nullity of a contract concluded with a worker in an irregular situation could not be invoked in order to evade payment of compensation. If the employer was not insured, it was the Employment Injury Compensation Fund that paid and subsequently claimed from the employer. If a worker who was to be paid compensation had not been affiliated to the scheme, the employer was liable to pay contributions in arrears. Within this context, the CEACR already stated in its 1980 General Survey on migrant workers that provisions of that kind could be envisaged as a proposal for future interventions. Concerning the access of irregular migrant workers in an irregular situation to public health care, the trend is for the vast majority of member States not to allow them the benefits of this protection. However, a few exceptions can be found in certain cases for emergency treatment.
} 
295. Conflicts between national laws serving different purposes raise important issues concerning governance in relation to migrant workers and the need to develop and adopt national policies to govern migration. This highlights the need for States to adopt a national policy to govern migration and the conditions of migrant workers, although this is not explicitly called for in the present Conventions. ${ }^{97}$

296. In terms of the management of international migration, the dividing lines between the protection of workers who wish to migrate for employment, the fight against irregular migration and the safeguarding of human rights are not always clear. Although efforts to curb irregular migration are legitimate and necessary, it is at the same time crucial to ensure respect for basic human rights. National provisions on irregular migration should be developed and reviewed in the light of the principle of necessity and proportionality and respect for the rights of all men and women migrant workers. ${ }^{98}$

297. Good practice to deal with irregular migration should begin with migration management that respects the rights of all migrants based on international instruments. ${ }^{99}$ Irregular migration should also be treated as a labour issue, not only as a security and legal issue, since the causes are often rooted in structural imbalances in the labour market. Social dialogue can help governments arrive at acceptable solutions since governments, employers and unions all have a stake in improving the situation.

\section{The impact of international regulation}

\section{Current impact}

Ratification levels, intentions to ratify and obstacles to ratification

298. Since 1999, Convention No. 97 has received two new ratifications; Convention No. 143 has received one; and the 1990 United Nations Convention has received 16 new ratifications following a ratification campaign. The ratifications levels of these instruments have evolved as follows.

299. As figure 4.1 indicates, ratifications of the 1990 United Nations Convention have gained a certain momentum based on a broad-based ratification campaign, after ten years during which it received little attention. So far, the parties to the United Nations Convention are primarily countries with net emigration, although Ghana, Mexico and Senegal, among others, are also destination countries for hundreds of thousands of migrants (some 2 million in the case of Mexico). National campaigns to promote ratification have been initiated in a number of industrialized countries.

\footnotetext{
97 See, however, Recommendation No. 151, Paragraph 1.

98 See General Survey, 1999, op. cit., para. 301.

99 United Nations Commission on Human Rights: Report of the Special Rapporteur on the human rights of migrants presented to the United Nations Commission on Human Rights, Geneva, 10 April 2003, doc. E/CN.4/2003/85.
} 


\section{Figure 4.1. Cumulative ratifications of ILO and United Nations instruments on migration}

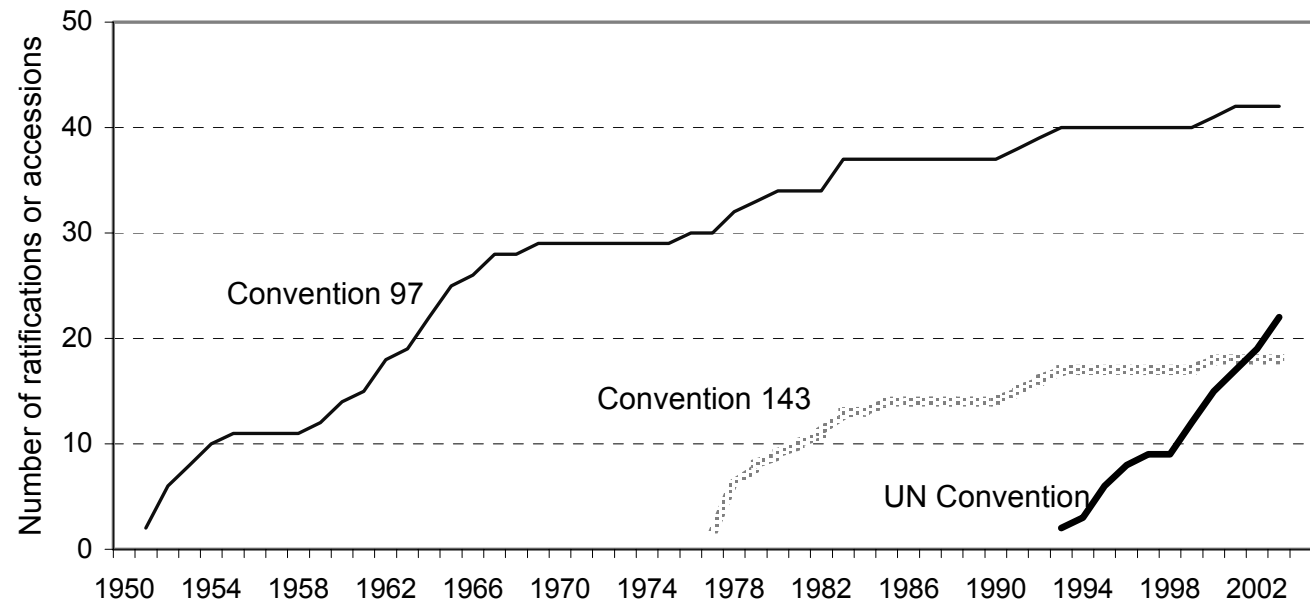

300. Convention No. 97 has attracted a total of 42 ratifications, more than half of which are from countries with net emigration. According to the ILM Survey, 12 member States were considering ratification, while 34 member States said that they had no intention of ratifying it. The obstacle referred to most often was non-conformity between national legislation and the Convention. Convention No. 143 has been ratified by 18 member States, including countries with both net immigration and net emigration. Ten member States also considered ratifying this Convention, but 40 States said they did not intend to do so. The obstacle again cited most often was non-conformity between national legislation and the Convention. ${ }^{100}$

301. While the specific instruments on migrant workers have not received large numbers of ratifications, the ratification levels of the other relevant ILO Conventions vary considerably. ${ }^{101}$ The fundamental Conventions are of course heavily ratified.

Standards used as models

302. The impact of standards, including both Conventions and Recommendations, is not limited to the impact created in ratifying countries. Member States also use them as models and apply them regardless of ratification. ${ }^{102}$ Generally speaking, countries tend to follow the provisions of these instruments in broad terms, but less so when it comes to provisions calling for more specific commitments regarding to the protection of migrant workers. ${ }^{103}$

\section{Increasing the impact}

\section{Promotion}

303. Promotion of ILO standards is not always pursued in a consistent way, either by the Office or by the ILO's constituents. Once submission to the competent authorities has been accomplished, there is no specific obligation to reconsider ratification

\footnotetext{
100 See Annex I, section 3.1.

101 Convention No. 95 (protection of wages) has received 95 ratifications, while Convention No. 157 (maintenance of social security benefits) has only three.

102 See Annex I, section 3.1.

103 See General Survey, 1999, op. cit., para. 647.
} 
periodically, and unless a focused promotional campaign is undertaken, ratifications may stagnate. However, promotion of standards may also help governments to understand the perceived obstacles to ratification and, in many cases, to overcome them. The increased level of ratifications of the fundamental Conventions is a telling example of the effectiveness of targeted, sustained and systematic promotional campaigns. Conventions Nos. 97 and 143 have not been the object of any targeted ratification campaign. This may be one explanation for their rather modest levels of ratifications. By contrast, the global promotional campaign for the ratification of the United Nations International Convention on the Protection of the Rights of All Migrant Workers and Members of Their Families - in which the ILO took part - had few financial resources at its disposal but was nonetheless successful. This instrument had attracted only nine ratifications in 1999 but following these promotional efforts it has now been ratified by a total of 25 countries.

304. Other ILO standards are promoted in the context of related ILO activities. A promotion targeted at addressing migrant workers' concerns could be based on and facilitated by a coherent presentation of all the relevant standards, including those on protection of wages, labour inspection, safety and health in construction, and others.

305. A further promotion measure that appears necessary would be to explore how to encourage the extension of national legislative coverage to categories of work regularly filled by migrant workers - especially agricultural and domestic work.

\section{Monitoring and supervision}

306. In terms of monitoring and supervision of standards, the ILO system comprises several distinct components, including supervisory machinery based on regular reporting. Reports received are examined by the Committee of Experts on the Application of Conventions and Recommendations (CEACR), a group of 20 independent legal experts. The report prepared by the CEACR on the basis of this examination is subsequently discussed in a tripartite context in the Conference Committee on the Application of Standards at the ILO Conference. This system provides information on the actual application of ILO standards and permits monitoring of their impact in practice. This supervision is designed for ratified Conventions. The impact of non-ratified Conventions and Recommendations is also monitored, although less systematically, through General Surveys such as the one carried out in 1999 in relation to the two Conventions and their two supplementary Recommendations concerning migrant workers. ${ }^{104}$ Since 1955, the ILO has carried out one such General Survey on one or more instruments relating to a specific subject matter each year.

307. The monitoring of United Nations instruments does not include the tripartite element built into the ILO's supervisory mechanism or scrutiny by independent legal experts.

\section{Impact of supervision}

308. The comments made by the CEACR on the application of Conventions relevant to this area demonstrate that migrant worker concerns are regularly monitored not only through Conventions Nos. 97 and 143 but also through other instruments, ${ }^{105}$ and that this monitoring covers the situation of migrant workers in a large number of countries. The

\footnotetext{
104 On the basis of article 19, paras. 5(e), 6(d) and 7(b) of the ILO Constitution.

105 See paras. 251-254.
} 
ILO's supervision of the situation of migrant workers is thus not limited to migrant workers in the countries that have ratified Conventions Nos. 97 and 143. ILO research has also demonstrated that this monitoring has had a positive impact, particularly in relation to the application of Conventions. ${ }^{106}$ It would be productive to take a more coherent approach to improving the situation of migrant workers by using the comments on all relevant Conventions as a basis for national action and for ILO technical assistance.

Tools for systematic review of national needs

309. It follows from the ILM Survey ${ }^{107}$ that a large number of member States consider there is a need to expand the ILO's knowledge base in the area of migrant workers. More systematic collection of information on national law and practice as well as an analysis of the national situation would respond to such a need. It would also constitute an important tool for the promotion of ILO instruments and the follow-up to their implementation, and would enable technical assistance to be adapted to national needs. Articles 10 and 19 of the ILO Constitution offer ample possibilities for developing such additional tools. ${ }^{108}$

\subsection{Preliminary conclusions}

310. It should be recalled that the purpose of the present discussion, based on an integrated approach, is to permit the constituents to examine different ways of improving the coherence, relevance and impact of the ILO's standards-related activities in the area of migrant workers, through a better use of its different means of action.

311. The ILO's body of standards is rich and varied. As the foregoing examination illustrates, several ILO standards are particularly relevant to migrant workers. These include, first and foremost, Conventions Nos. 97 and 143 and their Recommendations. It follows from this review that while these Conventions may have certain lacunae, they contain the principles that should be promoted for the protection of migrant workers. Migrant workers also benefit from the protection offered by other relevant ILO standards, including the standards concerning fundamental rights at work and standards relating to other areas such as employment, labour inspection, social security, wages, occupational safety and health, and private recruitment agencies, as well as sectors such as agriculture, construction and the hotel and restaurant sector, which traditionally employ large numbers of migrant workers.

312. Certain categories of migrant workers, however, do not benefit from an adequate level of protection, for a number of reasons. These include migrant workers in an irregular situation and certain other particularly vulnerable categories of workers such as domestic workers, many of them women, as well as, to some extent, temporary migrant workers.

313. Account should also be taken of the fact that the United Nations Convention on the Protection of All Migrant Workers and Members of their Families has recently entered

\footnotetext{
106 Particularly in the field of freedom of association and in relation to the application of Convention No. 118 (equality of treatment (social security)).

107 See Annex I, section 3.3, for details.

108 See also ILO: ILO standards-related activities in the area of occupational safety and health, Report VI, International Labour Conference, 91st Session, Geneva, 2001, para. 187.
} 
into force. This is a more recent instrument than ILO Conventions Nos. 97 and 143, and it is, in some respects, more closely aligned to modern developments in this field. It will be supervised by the United Nations' own supervisory process that will shortly begin to operate. It will not, however, have the support provided by the ILO tripartite structure and supervisory mechanism.

314. On the basis of the foregoing, therefore, what are the different options that could be considered?

315. A first option might be to launch a proper promotional campaign, coupled with structured technical assistance for the ratification of Conventions Nos. 97 and 143 and the application of their Recommendations. This action could be combined with the ongoing promotion of the United Nations Convention and would thus benefit from the strengths of the two organizations. Notwithstanding their different institutional contexts, these instruments contain a fundamental set of principles that should govern the protection of migrant workers and therefore constitute a broad and valid basis for immediate action in this field. However, relying on these three instruments alone does not provide a complete solution to all the problems concerned, relating in particular to irregular and temporary migration.

316. Addressing the lacunae that have been identified in the current standards could be done by adopting one or more complementary instruments in this area, for example, in the form of a protocol or guidelines. In this context account could be taken of the 1997 Guidelines on special protective measures for migrant workers in time-bound activities ${ }^{109}$ and consideration could be given to the possible need to update and/or complement them with guidelines concerning other vulnerable categories of migrant workers such as those having irregular status. Consideration could also be given to developing guidelines for the management and good governance of international migration that would be appropriate for present-day international migration.

317. Another option would be to launch a promotional action with respect to all the relevant standards reviewed in this chapter - including Conventions Nos. 97 and 143. Such a promotional initiative could contribute to fostering more comprehensive protection of migrant workers through a more effective application of these standards in national law and practice.

318. A possible way to enhance the efficiency of such an initiative would be to elaborate a new instrument which would serve as a promotional "engine" and be coupled with a follow-up mechanism and technical assistance. This instrument - which could be a Recommendation - would provide a coherent view of the principles, both for the protection of migrant workers contained in the relevant standards and for good governance of international migration in the present context of globalization. The purpose of this instrument and its follow-up would be to encourage the implementation of these principles. The follow-up should be based on systematically collected information on national law and practice, as well as on an analysis of national situations, in order to adapt technical assistance to national needs. Articles 10 and $19^{110}$ of the ILO Constitution offer ample possibilities for the regular collection of relevant information in this context.

\footnotetext{
109 See footnote 88 .

110 Paras. 5(e), 6(d) and 7(b).
} 
319. Finally, it should also be recalled that in the context of the discussion of the General Survey in the Conference Committee on the Application of Standards in 1999, a proposal was made for a full revision of Conventions Nos. 97 and 143 and the merging of these instruments into a single Convention, which would take account of present-day realities. ${ }^{111}$

111 ILO: Report of the Committee on the Application of Standards, International Labour Conference, 87th Session, Geneva, 1999, para. 174. 


\section{Chapter 5}

\section{ILO activities with governments and social partners}

\subsection{Introductory remarks}

320. This chapter outlines the main elements of the ILO's activities in the field of international labour migration. The economic and social policy issues raised by labour migration cut across practically all spheres of the normative and technical activities of the ILO. The search for employment and socio-economic security is the principal motive for the migration of workers, which gives rise to important employment policy issues in both source and destination countries. The social protection of all workers, including migrant workers, is at the core of the ILO's work, whether it is to protect workers against forced labour and against discrimination, provide them with social security coverage, reduce poverty and create decent jobs, create more and better jobs for women, combat trafficking or stop the spread of HIV/AIDS. As discussed in the previous chapter, most ILO standards and norms apply to migrant workers. Today a large number of the ILO's normative and technical cooperation activities have a direct bearing on migration and the conditions of migrant workers, and are in turn influenced by them.

\subsection{A core agenda}

321. A core agenda for labour migration policy comprises seven basic components: (1) applying international standards to protect the basic rights of all migrants; (2) monitoring migration and the conditions of migrant workers; (3) consulting social partners and other stakeholders; (4) developing coherent national policies and measures on labour migration, based on ILO principles; (5) enhancing administrative capacities for managing migration; (6) preventing discrimination and facilitating the social and economic integration of immigrants; and (7) engaging in regional and international dialogue and cooperation.

322. The Office's activities have evolved along lines corresponding to this core agenda and have been grouped into the following main themes:

- building a global knowledge base on labour migration through research and the International Labour Migration (ILM) database;

- promotion and supervision of relevant ILO norms;

- promoting and strengthening social dialogue on migration and integration questions;

- technical cooperation to assist governments and social partners in improving their capacities for policy-making and administration; 
- $\quad$ special action programmes to combat trafficking and forced labour of both children and adults, to protect groups at risk, especially from HIV/AIDS, and to promote integration and non-discrimination;

- building an international framework for cooperation on migration.

\section{(a) Building the knowledge base}

323. ILO studies on migration and migration policy have long been standard references for specialists and for policy-makers. They can be broadly divided into three categories: studies identifying migration trends, their causes and consequences; studies documenting and evaluating the policies of countries of origin; and studies documenting and evaluating the policies of countries of employment. Some of the earliest evaluations of the guest worker programmes in western Europe came from ILO research, as did early reports on the emergence of a labour migration system in the Gulf region. The studies on the experience of Asian countries of origin in regulating recruitment and contract labour migration are still important reference points for countries in other regions seeking models for managing emigration. For countries that are experiencing irregular forms of migration, ILO research on how employer sanctions and regularization measures work is particularly instructive. All these studies have since been synthesized into manuals to support the Office's advisory work.

324. The growing demands from member States for policy advice underscore the need for further expanding the ILO's knowledge base, especially in new and growing regions of migration and on issues arising from the increasing complexity and diversity of crossborder movements of workers in an era of globalization.

325. Some years ago, the ILO started an International Labour Migration Database, providing online data from more than 80 countries on labour migration flows, stocks and employment characteristics. It was designed and is being implemented in coordination with the United Nations, the OECD and EUROSTAT to avoid duplication and to enhance complementarity. Limited resources as well as the scarcity of national statistics on migration have impeded further development and wider participation by developing countries in some regions.

326. Two main series of publications disseminate research findings and specialist views on policy questions. The ILO's International Migration Papers series, which started in the mid-1970s, has been bringing out the results of empirical studies on a broad range of issues, from emigration pressures in North Africa to the integration problems of secondgeneration migrants in Europe; from the conditions of mineworkers in South Africa to the impact of CARICOM on the actual movements of workers in the Caribbean. A new Perspectives on Labour Migration series, which started in 2003, provides a vehicle for the exchange of specialist views on selected migration policy issues. These studies and the ILM database are made available to the general public worldwide through the ILO web site. Migration research papers, articles, statistical data and reports on relevant activity are posted at http://www.ilo.org/migrant .

327. NATLEX, the ILO's database on labour legislation, also contains information on migration law together with useful country profiles. This database will be enriched by the information sent in by countries responding to the ILM Survey. Many respondents drew attention to the usefulness and value of such a collection of laws on migration for policy-making and administration. 
328. The ILO's work on migration also draws on a much larger information base accumulated under the auspices of a large number of technical cooperation programmes in the field and at headquarters. These include the ILO's country programmes to promote employment and decent work, and studies on the social dimensions of globalization, improving key labour market indicators, child labour, more and better jobs for women, trafficking and forced labour, social finance, conditions of work, crisis response, social security, HIV/AIDS, and on working conditions in several important economic sectors, including agriculture, construction, the maritime sector, communications, tourism and health.

\section{(b) Promotion of norms}

329. The wider acceptance and integration of ILO standards and principles, both in national migration policies and in international treaties, remains the fundamental objective of the ILO's work in this field. This is undertaken at various levels, in the regions and at headquarters, through advisory missions, training programmes and national and regional conferences, and through collaborative work with other international and regional organizations such as the Office of the High Commissioner for Human Rights (OHCHR), UNHCR, the IOM and the Council of Europe. ${ }^{1}$

330. As ILO Conventions and the International Convention on the Protection of the Rights of All Migrant Workers and Members of their Families of 1990 share a common purpose, the ILO has participated since 1998 in the inter-agency Steering Committee for the Global Campaign for ratification of the International Convention, a multi-agency effort which has already contributed to ratifications by several countries.

\section{(c) Social dialogue}

331. Labour migration policies are likely to have broad support if they are developed with the full participation of those representing the interests of the most directly affected parties, namely the employers and workers. However, formal structures at national level that allow for active participation of social partner organizations in labour migration policy and administration are still very few and far between. Preparing the tripartite partners for such a role in migration policy is now being given due emphasis in the design of ILO seminars and related activities. The Office has even facilitated participation by regional and national employer and union organizations in recent activities organized under the auspices of outside organizations. ${ }^{2}$ ACT/EMP and ACTRAV have each designated a focal point officer for labour migration concerns, and produced a special issue of the publication Labour Education on migrant workers in 2002, which covered in some depth the situation of migrant workers and the possible role of workers' organizations in improving it.

\section{(d) Technical cooperation}

332. Technical cooperation is now a major means of action for achieving the ILO's mission and objectives. Through externally funded projects the ILO has been able to offer more substantive technical assistance to member States in various aspects of labour

\footnotetext{
${ }^{1}$ Recent examples are subregional tripartite seminars in Africa (Pretoria, Douala, Dakar, Arusha), International Migration Policy Programme (IMP) conferences in Africa and Central Asia, a tripartite regional conference in Asia, and ILO contributions to regional conferences in Central and Latin America (San Jose, Lima, Santiago, Montevideo).

2 IMP conferences in East and West Africa and Central Asia (see para. 19).
} 
migration policy and administration than its own resources would permit. Regional technical cooperation projects carried out in Asia, North Africa, and in Central and Eastern Europe, for example, have enabled the Office to meet in a cost-effective manner countries' common needs for information and training in the management of labour migration. They supported the establishment of networks among labour ministries which continued long after the externally funded projects had ended. Through technical cooperation the Office has assisted governments in developing a firm base for national policies by grounding them on conditions in national and international labour markets, by harmonizing national with international normative standards, and by broadening support for policy through social dialogue.

\section{Box 5.1}

\section{The ILO's advisory work on labour migration}

Two main approaches characterize ILO technical cooperation. One comprises advisory missions, seminars and/or short-term expert projects at the request of member governments to address specific needs and situations. Over the last few years, these have included advisory missions on general issues of improving national migration policy (Bahrain, Bulgaria, Costa Rica, Islamic Republic of Iran, Kuwait, Republic of Korea and Thailand); formulating legislation (Azerbaijan, Georgia and Turkey); and/or establishing frameworks for protecting nationals going abroad (Albania, Bangladesh, China, Indonesia, Mongolia, Nepal). Similar requests have been received from Armenia, Ecuador, Mauritius, Poland, Serbia and Montenegro and the Democratic Republic of Timor-Leste.

Another approach addresses multilateral migration issues. The Office has been asked, for example, to advise the ASEAN countries on the feasibility of a regional agreement on social security for migrant workers. A draft was prepared some years ago but agreement has so far not been reached. More recently, an assessment of trends in cross-border movements in the CARICOM area has been undertaken with a view to identifying areas of converging interests in further advancing labour market integration. The Gulf Cooperation Council has sought advice and information on other regions' experience of labour market integration. Basic research on the policy implications of liberalizing cross-border movements and allowing the freer circulation of labour will be very important in the future advisory work of the Office.

333. A project entitled the "African Labour Migration Policy Initiative" has obtained financial support from the European Union and is due to be launched in March 2004. It will provide assistance in policy development to the five Maghreb countries, the three countries of the East African Community and the members of the West African Economic and Monetary Union (WAEMU). The main areas of emphasis in these three concurrent subregional programmes are: strengthening data collection and analysis; facilitating labour mobility in regional integration processes; addressing the "brain drain"; and preventing exploitation and discrimination, with the overall objective of enhancing development. A similar project is being initiated jointly with the IOM in the Southern African Development Community (SADC). An integrated regional approach is also planned for Central Asia, the Caucasus and several Eastern European countries.

334. Two other smaller projects have recently started. One of these, which aims to help the Governments of Albania, the Republic of Moldova and Romania to design national programmes on labour migration and counter trafficking, was launched in late 2003 with support from Ireland Aid. The other project aims to enhance national capacity for the effective administration and management of labour migration flows in Cambodia, Lao People's Democratic Republic, Mongolia and Thailand. It will start in early 2004 under the auspices of the Republic of Korea-ILO strategic partnership. 
335. Technical cooperation at the country level is exemplified by a project supported by the Italian Ministry of Labour and Social Welfare aiming to assess the employment difficulties faced by migrant workers in Italy because of discrimination. Based on the methodology used in earlier ILO studies in Belgium, Germany, the Netherlands and Spain, research was conducted in three Italian cities in 2003 to measure discrimination in access to employment faced by immigrant and minority workers. Its findings will assist the Government and social partners of Italy in combating discrimination in employment more effectively and implementing the EU Directive on racism (Council Directive 2000/43/EC).

336. A technical cooperation project to enhance tripartite cooperation in facilitating integration and combating discrimination against migrant workers in Europe will be initiated in mid-2004 with support from the European Union INTI fund. This will build on the Office's earlier work on a compendium of anti-discrimination "good practice" measures from employers, unions, governments and NGOs from most European countries, which will be available online as of March 2004. A practical handbook and other materials will be published to assist constituents in conducting effective antidiscrimination work.

\section{(e) Capacity building}

337. The Office, in cooperation with the ILO International Training Centre in Turin, has developed a tripartite training module on labour migration incorporating interactive discussions with experts, validation of participants' experience and collective elaboration of plans and commitments for follow-up activity. Subregional tripartite capacity-building seminars using this approach were held in southern Africa, Central Africa and West Africa in 2002-03. Regional and topical seminars are scheduled for Africa and Latin America in 2004. The Turin Centre has also been engaged in the work of promoting ILO instruments on migration for employment through several courses designed specially for administrators of migration policy, and in several instances specifically for labour attachés.

338. Through its participation in conferences convened by the inter-agency International Migration Policy Programme (IMP), the ILO has been able to stress the centrality of labour issues in migration and the need to adopt appropriate normative, policy and practical administrative measures as core elements of sound migration policy. These activities (Dakar, 2001; Nairobi, 2002; Istanbul, 2003; Addis Ababa, 2003; Bishkek, 2004), have so far involved senior officials from the foreign affairs, interior and other ministries of 65 governments in West Africa, Central Asia-Caucasus and neighbouring countries, East Africa and the Horn of Africa.

\section{(f) Special action programmes}

339. Some of the ILO's global initiatives and programmes are particularly important in addressing the most severe challenges to protection in the field of migration. These programmes are helping to develop common understanding, cooperation and effective action across borders, and they attract resources and attention that no national or regional effort has achieved.

340. Seven major regional projects to combat trafficking in children, covering more than 45 countries, are operational under IPEC auspices in South Asia, West and Central Africa, Central America, the Dominican Republic, South America, Eastern Europe and the Balkans, and the Greater Mekong Subregion. These projects reflect an integrated approach towards the prevention of exploitative work and the withdrawal of children 
from it by addressing the root causes of trafficking - poverty, inadequate education and lack of decent work for adults.

\section{Box 5.2}

\section{The ILO's Special Action Programme to Combat Forced Labour (SAP-FL)}

This global programme addresses the trafficking of migrant workers, focusing on the forced labour outcomes. National studies are being conducted on the characteristics and consequences of the trafficking of migrant workers in a number of Asian and European countries. An ILO overview paper, Trafficking in human beings: New approaches to combating the problem, was first issued in May 2003. SAP-FL approaches human trafficking from a broader labour market perspective in both countries of origin and destination countries, aiming to involve key labour institutions and players in coordinated anti-trafficking activities. Research examines both demand and supply aspects, identifying the extent to which irregular migrants are subjected to coercive recruitment and employment conditions in certain economic sectors. Many partners welcomed this focus, which draws more attention to labour market initiatives as a key element of global action against trafficking. Training seminars for labour officials from Central and Eastern Europe were held in Bucharest and Turin in early 2004. Operational projects have started in Europe, Central Asia, West Africa and South-East Asia, with activities in countries of origin and destination countries. Technical assistance is being provided to member States on the identification of forced labour cases in new anti-trafficking legislation and law enforcement.

341. In 2001-02, studies documenting discrimination against women migrant workers were conducted under the auspices of GENPROM in Bolivia, Costa Rica, Ethiopia, Italy, Japan, Nicaragua, Nigeria, Philippines, Romania, Sri Lanka and the United Arab Emirates. These studies yielded valuable insights into the situation of women migrant workers and on how they can be assisted at various stages of the migration process, and served as the basis for training seminars at the Turin Centre on the identification of antitrafficking strategies, and for policy advocacy. The good practices documented in the 11 country studies served as the material for the ILO's information guide on women migrant workers, which was issued in 2003 to enhance the efforts of government agencies, workers' and employers' organizations and NGOs in all countries to improve protection, reduce exploitation and abuse, and prevent trafficking of female migrants.

342. Finally, ILO-AIDS has given particular attention to identifying challenges and remedies concerned with reducing the risk of HIV/AIDS among mobile and migrant worker populations; the Office has cooperated with UNAIDS, the WHO and the IOM on research and joint advocacy on this issue.

\section{(g) Building international cooperation}

343. Since the great majority of migrants worldwide are economically active, the ILO has an essential role to play in forging international cooperation for managing migration. Much of today's migration is due to widening economic gaps, lack of employment opportunities at home, and conditions in labour markets. One of the key migration issues facing the international community is the protection of migrants against exploitative treatment. The rising emphasis on migration as a labour and economic concern, rather than as a security issue, in current international policy discourse certainly coincides with increased ILO activity in the field.

344. The United Nations itself provides the most important avenue for building international cooperation. The ILO has brought migration and workers' rights issues to 
relevant sessions of the Commission on Human Rights and the General Assembly. It has supported the United Nations Special Rapporteurs on Human Rights of Migrants and on Rights of Non-Citizens with information and advice. The Office likewise cooperates actively with other United Nations agencies as well as with the International Organization for Migration (IOM) at policy and technical levels, in bilateral activities and in multilateral forums such as the intergovernmental organization (IGO) Contact Group on Human Trafficking and Migrant Smuggling. More significantly, the ILO's Director-General is a co-founder of the Geneva Migration Group, a recently established informal association of the executive heads of United Nations and international agencies in Geneva dealing with migration and refugee questions.

345. A few important initiatives have been launched recently by some governments and international organizations to create a multilateral framework of cooperation for improving migration governance. The ILO is an active member of the Steering Committee of the Berne Initiative, a project launched by the Swiss Government and now supported by a number of others aimed at improving global governance of migration through multilateral action. The ILO is also a co-sponsor of the inter-agency International Migration Policy Programme together with the IOM, United Nations Population Fund (UNFPA) and the United Nations Institute for Training and Research (UNITAR). The latest initiative is the establishment of the Global Commission on Migration by several governments, notably by the Governments of Sweden and Switzerland.

346. The ILO has sought to strengthen coordination with regional structures as well. In late 2003, migration was agreed as one of the five priority areas for implementation of the newly established EU-ILO strategic partnership. The ILO contributed to the draft strategic framework for a policy on migration in Africa developed under African auspices. ILO observations have been actively solicited in the Council of Europe Committee on Migration (CDMG). In addition, high-level ILO officials in 2003 addressed the 5+5 Dialogue conference on migration in Rabat and, in 2002, the 7th Conference of European Ministers Responsible for Migration Affairs in Helsinki, the Hemispheric Conference on Migration, Human Rights and the Trafficking in Persons in Santiago de Chile, the European Red Cross and Red Crescent Regional Conference in Berlin, and the Asia and Pacific Regional Conference of Red Cross and Red Crescent Societies in Manila.

\subsection{An integrated programme within the ILO}

347. The challenges posed by migration require responses which can draw on competencies, programmes and activities within the ILO. These encompass a vast range of competencies in different departments, both at headquarters and in the field. ILO activities in many regions in the field of employment policy address the underlying factors behind migration pressures and the conditions of employment facing migrant workers. The ILO's programme on standards and fundamental principles and rights at work is obviously central to the promotion of a rights-based approach to migration management. ILO activities aimed at promoting safer and better conditions of employment and enlarging the population covered by social security are as relevant to migrants as they are to national workers, if not more so. And the establishment and strengthening of social dialogue is of critical importance in making sound migration policy and obtaining broad support for it. 
348. Building an integrated programme on migration from this vast array of technical competencies and activities is the central task of MIGRANT, the ILO's specialized technical unit for migration. It identifies the issues that need to be addressed by the ILO and finds the means for tackling them by mobilizing knowledge, competencies and financial resources from inside and outside the Organization. This has proved to be a formidable task, given its limited resources and the rapidly growing demands for ILO involvement in a wide range of migration issues. In 2003, for example, this entailed involvement in regularizing the status of migrant workers in Thailand, harmonizing policies in support of free movement of labour in West Africa, identifying and documenting best practices for reducing discrimination against immigrants in western Europe, improving the management of recruitment in places as diverse as Nepal and the United Republic of Tanzania, spreading information on how migrants can be induced to invest in their communities of origin in Mexico, assessing the conditions of migrant domestic helpers in Central America, and developing strategies to combat trafficking in young women from a number of States in the CIS region.

349. The replies to the ILM Survey indicate a very strong demand by member States for further support activity from the ILO (see figure 5.1). A total of 47 countries replied that they needed technical cooperation from the ILO on improved migration statistics, 32 needed technical cooperation on development of labour migration policy, 22 on review/reform of legislation, 22 on development of national administrative infrastructures, 29 on capacity building of employers' and workers' organizations, 33 on strengthening labour inspection, 22 on promotion of equality of treatment and 24 on gender-specific issues of migration policy or practice. A number of countries indicated a specific need for technical cooperation in one or two areas. Some 20 indicated a need across the board in all categories. Most replies received directly from several national trade union federations also expressed the need for assistance in some or all of these categories. Employer representatives have urged the ILO to address companies' needs in labour markets.

\section{Figure 5.1. Technical cooperation required from the ILO (No. of respondents)}

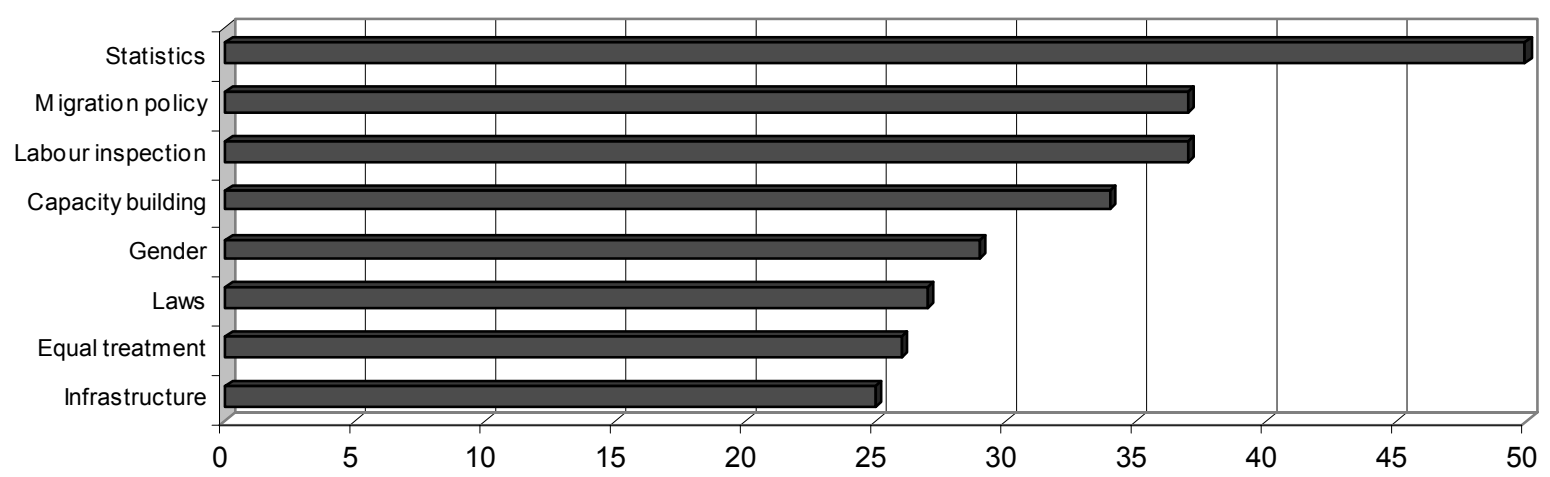

Source: ILM Survey, 2003.

350. A growing proportion of ILO activity on migration is implemented through regional and field offices. Migration featured as a central priority in plans agreed for the Asia and Middle East regions, and was explicitly included for Africa, Europe and Latin America in the joint ILO programme planning exercise of November 2003. 
351. Many of these activities have already had concrete results which are expected to contribute to the improvement of the actual conditions of migrants in many parts of the world. A few examples may be cited to illustrate this. The ILO's technical assistance project on migration management has already led to the signing of a Memorandum of Understanding between the Governments of Thailand, Myanmar, Lao People's Democratic Republic and Cambodia, under which migrant workers will receive wages and benefits at the same rate as national workers in accordance with the principles of non-discrimination and equality with respect to gender, ethnicity and religious identity. In the Republic of Korea, a new law providing for the temporary admission and employment of foreign workers has been passed, based in part on ILO advice. The Office promoted this policy reform after identifying deficiencies in the previous trainee system and advised the Ministry of Labour on best practices with respect to preparation of the legislative proposals.

352. In Belgium, ILO research on Combating Discrimination Against Migrant and Ethnic Minority Workers in the World of Work was credited with shaping the content of national legislation adopted in 2003 by the Belgian Parliament putting into effect the EU Directive on racism (Council Directive 2000/43/EC). A campaign against discrimination was established at regional and federal levels with the involvement of the three national trade union federations and the national federation of employers. In Ireland, the ILO helped the Government and social partner institutions draft an "action plan" for trade union and business anti-discrimination/integration in 2003.

353. The impact of ILO action against child trafficking has included recognition of its role, methodology and outcomes at the global level (Yokohama Conference, United Nations General Assembly), expanding demand for ILO technical cooperation and advisory services in different regions, and increasing donor willingness to finance largescale projects against child trafficking.

354. In Mauritius, the Ministry of Labour and Industry credited ILO principles, standards and training for its decision to set up a "special expatriate squad" to oversee all aspects of employment of foreign workers. In Mongolia, the Ministry of Labour has set in motion the programme of action adopted at the ILO Workshop on Overseas Employment in 2002 which included a closer monitoring of the activities of recruitment agencies.

\subsection{Preliminary conclusions}

355. The foregoing discussion of the ILO's activities illustrates the relevance of ILO normative and technical cooperation activities to tackling the wide variety of migration issues. These activities underscore the important position that labour migration occupies in the ILO's mission and suggest that the ILO has a key role to play in the wider effort to resolve the many dilemmas with respect to migration facing the international community. Greater participation by the tripartite constituents in the various regional and global initiatives to discuss and develop cooperation on managing migration would appear to be essential.

356. The International Labour Migration Survey indicates that member States are expecting a further expansion of technical cooperation activities in the field of migration. Supporting and sustaining these activities and the initiatives at regional and international level that the ILO might wish to take in the future, especially following the general discussion, will require a review of the adequacy of resources devoted to the ILO's International Migration Programme. 


\section{Chapter 6}

\section{Managing migration}

\subsection{Introductory remarks}

357. Migration represents one of the most complex policy challenges for governments. They find themselves balancing a host of different issues and interests, some economic, some social, some political. These are in essence concerned with ideas of difference and equality: migration is fuelled by differences between countries, and yet the protection of migrants demands equal treatment for all workers, whatever their nationality.

358. Unlike other aspects of globalization, such as increased trade or investment, migration of labour, even for temporary periods, provokes significant social and political adjustments which are often stressful, and has implications for a range of economic and social policies - from education, health and social welfare, to international development. Governments concerned about migration must therefore go beyond mere gate-keeping and integrate migration policy into mainstream planning. ${ }^{1}$

359. This chapter, which is based on the experience of many countries and on responses to the International Labour Migration Survey, looks at the available opportunities for improving the governance of migration. Migration policy decisions are hard to reverse, so they need to be based on a consensus regarding long-term interests; and since migration can involve losses and gains both for individuals and for source and destination countries, ways must be found to distribute the benefits of migration more equitably.

360. Sustainable policies must therefore be based on open debate and social dialogue among the most important stakeholders, and consistent with policies in other spheres of governance, particularly in the management of the economy and the promotion of political stability. It is in the nature of liberal democracies for strong differences to exist on policy directions and how they are to be managed. Political leaders have a responsibility to inform and educate the public on the implications and consequences of migration. Policies need to be made transparent and coherent, yet administered sufficiently flexibly to allow policy-makers to learn from experience.

361. This chapter further argues that while many elements of immigration policy will continue to be in the domain of individual state policy, there is an evident need for more multilateral approaches to managing migration. Existing unilateral approaches to establishing order in migration are proving inadequate to cope with the rising mobility of people across borders for reasons of tourism, work, business, study or asylum. The ever-

\footnotetext{
${ }^{1}$ See S. Spencer (ed.): The politics of migration: Managing opportunity, conflict and change, Special Issue of The Political Quarterly (Oxford, Blackwell Publishing, 2003).
} 
growing size of populations in an irregular status is evidence of that failure. In order to protect migrant workers, the ILO will need to go beyond its normative work to actively promote, in partnership with other international organizations, cooperative schemes for managing migration.

\subsection{Choosing policy directions}

362. History shapes and constrains migration policy choices. Wars, for example, have often caused political boundaries to be drawn and redrawn, so that some people, even without migrating, have found themselves living within the territory of a nation other than the one in which they were born. Past colonial arrangements have also played a part, since they generally allowed for free movement between the imperial centre and the territories and thus established migration flows that changed the ethnic character of source and destination countries. Finally, governments have also made deliberate choices that affect migration by adopting common borders. This has happened in the European Union, which now guarantees free movement of labour for nationals of all its Member States.

363. Migration policies are shaped by balancing different, and at times conflicting, interests and objectives. Family reunification remains an important value underlying the immigration priorities of most countries, but also has to be balanced with employers' concerns regarding the need to tailor policy to meet labour shortages. Temporary foreign worker programmes are established to meet cyclical labour shortages, but the way to sustain such policies may involve an unacceptable limitation of workers' rights. The admission of highly skilled foreign workers may be considered an imperative to maintain global competitiveness in certain industries or as a means to stimulate growth, but it may be opposed by native workers whose wages may be depressed.

364. Because policies have significant long-term implications which go beyond their intended effects, the course that is chosen is of critical importance. For example, in the 1950 s, as a result of rapid economic recovery, both Germany and Japan were faced with emerging labour scarcities, but chose very different solutions. Japan decided not to open her doors to foreign labour and instead used a variety of policy instruments to press Japanese firms to adopt labour-saving processes and eventually to use direct foreign investment to relocate production to lower-wage countries. West Germany, as it then was, also experienced rapid economic growth and full employment, while its labour force was shrinking. Planners in West Germany, unlike those in Japan, were reluctant to put their faith in mechanization and rationalization, on the grounds that they might jeopardize what was perceived to be a fragile economic recovery. German leaders considered that importing foreign labour temporarily would be less risky and embarked on the now famous Gastarbeiter ("guest worker") programme.

\subsection{Towards greater policy coherence}

365. One of the major challenges to the governance of labour migration is policy coherence. At the very least, policy coherence must ensure that migration policies are directed at meeting foreseeable long-term requirements of the economy and society, and remain in place regardless of changes in government. However, in a broader sense, policy coherence means ensuring that policies and programmes in both migration and other sectors do not undermine each other, either directly or through unintended consequences. Rather, governments should take measures that support legal migration, 
ensuring that foreign workers receive wages that are not lower than those of local workers, and using sanctions and other means to discourage the employment of irregular workers.

366. Some of the perceived policy failures associated with "guest worker" programmes arose from unrealistic expectations about how closely migration could be fine-tuned to respond to economic cycles; in fact, it is often not possible to turn migration on and off like a water tap. Policy-makers may also have assumed, erroneously, that temporary worker programmes do not affect relative wages, or returns on capital or to owners of other productive assets. In fact firms adjust their production strategies, and structure the jobs they create, according to their expectations about the availability and cost of labour; once they have made investment decisions on the assumption that migrants will continue to be available, they will understandably resist policy changes that would deny them access to such labour.

367. Policies based on the assumption that migrants can be brought in when needed and sent home when no longer needed are bound to fail. Such policies, which are premised on making migration a counter-cyclical measure against instabilities in the labour market, have failed in every region where they have been tried. The reason was summed up in one phrase by the Swiss writer Max Frisch: "We invited guest workers, and got human beings." As social beings, men and women have needs that go beyond physical maintenance. Moreover, host societies and economies adjust to their presence and come to depend on their services.

368. Lack of policy coherence is often a reflection of the conflicting pressures on political leaders who are nervous of losing the support of key constituencies. One consequence is the contradiction between political pronouncements and what happens on the ground. For example, a government may play up its opposition to the use of unskilled foreign labour and its determination to stop irregular migration, while in practice actually subsidizing and protecting sectors, such as agriculture, that absorb unskilled foreign labour. It may also fail to regulate wages and working conditions, giving some employers an incentive to hire irregular workers to save on labour costs, or allow firms quite legally to pay below-minimum wages to foreign "trainees" who are in fact workers. Politicians who fail to develop clear policies on migration run the risk of appearing hypocritical and losing public support, leaving policy at the mercy of extremist pressure groups. In many countries it is still an open question as to whether or not a more liberal immigration platform can be a vote winner.

\section{Flexibility in administering policy}

369. Policy coherence does not, however, mean that the administration of migration policy should be inflexible. As many national authorities have learned from experience, some of the best designed procedures to manage migration can go awry because it is very difficult to anticipate the responses of the main players in the labour market. In the United States, for example, the H1B visa category was created to meet the demands of private industry for highly skilled workers when these could not be found within the domestic labour market. However, the "body shops" that recruited skilled foreign workers and placed them in jobs in the United States found it advantageous to obtain as 
many visas as they could, regardless of demand, so some brought in foreign workers even when there were no jobs available for them. ${ }^{2}$

370. Policies will always need to be adjusted to changing circumstances and shifting objectives. Experience shows that planned migration is rarely achieved. This was the experience with the German Gastarbeiter programme and with the earlier Australian policy to keep Australia white and British. Circumstances change and migration outcomes may bear little relation to the original objectives of the policy, but this does not necessarily mean that the policy has failed.

\subsection{The value of social dialogue}

371. Migration has, or is perceived to have, consequences that disadvantage certain groups, particularly the less skilled and older workers, either through displacement or by lowering wages. Migration has also been blamed for all kinds of social and economic ills, from unemployment and displacement of nationals in the labour market, to illicit drugs, street crime, terrorism and HIV/AIDS. Since migrant groups seldom have any opportunity to defend themselves, they have become easy targets for extremist groups looking for opportunities to advance their political agenda. Few policy-makers want to take chances on such a divisive issue, and during periods of economic crisis they may choose simply to repatriate foreign workers and close the migration gates. This happened recently in South-East Asia in the aftermath of the 1997 Asian financial crisis, for example, but has also occurred in other parts of the world. Even the most responsible political parties have been known to play the "migration card" in order to win more votes.

372. Rescuing migration policies from the demands of street politics will require an informed debate that can reach a broad social consensus among representatives of those who stand to gain and those who stand to lose. These are the employers, the workers, and the government representing society as a whole. Social dialogue can help to form a sound approach that commands broad support. Responses to the International Labour Migration Survey indicate that, when amending or adopting laws pertaining to national immigration policy, most countries hold regular consultations with representative employers' and workers' organizations. There are, however, only a few examples where the formulation of labour migration policies, laws and regulations takes place through formally established tripartite structures.

373. This type of dialogue is also needed in the countries of origin - especially where governments have assumed responsibility for regulating the recruitment and contracting of their nationals. Here, too, there can be winners and losers. The migrant workers and their families will gain but the society they leave behind may lose out, especially when skilled workers are lost. For example, when Jamaica lost two-thirds of its nurses to other countries, its hospitals could no longer provide the same quality of treatment. And when Pakistan lost its best masons and carpenters to the Gulf States during the 1970s and 1980 s, it also lost the more senior workers who could pass on skills to younger apprentices, thus damaging its informal training systems. Not surprisingly, domestic industries in origin countries that lose skilled personnel will have little incentive to invest in the development of skills other than firm-specific skills.

${ }^{2}$ P. Martin and M.I. Abella: Globalization and guest workers: Migration for employment in the 21st century (forthcoming). 
374. Where an origin country establishes appropriate policies and structures for managing emigration, workers usually opt to migrate through established legal channels and are thus better protected. The Philippines is a good example. The country has two key agencies responsible for labour migration policy and administration - the Philippine Overseas Employment Administration (POEA) and the Overseas Workers Welfare Administration (OWWA), for both of which the Government has established tripartite advisory boards. The POEA has been credited with many innovations, including the policy of making private recruitment agencies jointly liable with foreign employers for any contract violations, while also providing incentives and awards for good performance, and for the introduction of an Internet-based "paperless" contract approval system. As a result, Philippine workers are some of the most sought-after abroad and are known to receive higher wages than their counterparts from other countries.

\subsection{Aligning foreign labour admissions with economic needs}

375. Not all migration policies are driven by labour scarcity. The United States, Canada and Australia have a tradition of encouraging long-term immigration, and a key foundation of their migration policy is to encourage family reunification. Even in Europe, after the ending of guest worker programmes in the early 1970s, governments continued to permit family reunification - which became virtually the only legal channel for immigration from non-EU countries. However, by the 1990s, thanks to the huge investments in information technology, most governments were looking to use immigration to solve skill shortages - resurrecting the debates over how successfully states can align migration policies with the short- and long-term needs of their economies.

376. The major reasons usually presented for increasing the supply of workers via immigration are:

- Meeting a temporary demand for workers - the belief that the labour demandsupply gap is only temporary and will subsequently be filled by local workers, including students who are currently in training.

- Supporting strategic industries - some labour-short industries have a strategic value that might be lost if the industry migrated abroad, or expanded more slowly owing to a lack of labour.

- Building a global workforce - the need to train foreign workers for branches or subsidiaries abroad as part of a global workforce.

- Avoiding inflation - the desire to curb wage inflation in one industry, occupation or area that could have spillover effects in other labour markets or could lead to rising consumer prices.

377. These reasons tell us why countries might choose to open the border gates, but not how many migrants they should admit. Planning immigration to meet labour market requirements may take different tracks. Traditional immigration countries such as Canada and Australia do not only recruit immigrants for specific jobs or for immediate labour market scarcities, but also choose immigrants on the basis of their long-term capacity to integrate in the labour market, so that migrants who pass points tests for admission are free to choose and change jobs as they wish. 
378. Other countries make more efforts to match foreign workers to immediate labour market needs. This is a complex undertaking. Ascertaining labour scarcity for each and every occupation at specific points in time, and for each region within a country, is difficult, so that governments inevitably use simple labour market tests and allow agencies considerable latitude in administering labour market-based migration policies. In some cases, the government takes a laissez faire approach. Some put the onus on the company to prove that no national workers are available for this assignment - that they have advertised the post but found no qualified applicants. This can be expensive and time-consuming. In other cases, like the United States, the employer simply attests that the workers are needed and the prevailing wage will be paid, and there is generally no enforcement unless complaints are made.

\section{Box 6.1 \\ Minimum waiting period to establish scarcity}

The period during which employers must offer jobs to national workers varies from one country to another. In Mauritius and Tunisia, for example, employers have to prove that there is a lack of qualified applicants after a job vacancy has been advertised for two weeks; in Lebanon the period is three weeks; in Ireland, the Republic of Korea, Poland and the United Kingdom, it is four weeks; in Portugal, five weeks; and in the Netherlands it is five to 12 weeks. In some countries, however, as in Belgium, the burden of proof lies with the competent authority, which must demonstrate that there is no labour scarcity.

Source: ILM Survey 2003.

379. Other countries discourage the employment of foreign workers in different ways. Singapore, for example, requires employers to pay a migrant workers' levy or tax. ${ }^{3}$ Others offer migrant workers a premium over wages offered to nationals - as in Bahrain, Czech Republic, Kazakhstan, Poland, Senegal and Slovakia. But one of the commonest ways of ensuring that employers are not resorting to cheap migrant labour is to require them to pay migrants at least the same wages as nationals.

\section{Establishing quotas}

380. Some countries have established foreign worker quotas. These can be applied to specific parts of the country or, more commonly, to certain occupations in designated sectors like agriculture, industry or hotels and tourism. Austria, for example, has quotas for seasonal workers in tourism and agriculture. France, Greece, the Republic of Korea, Mauritius, Netherlands, Portugal and Senegal have quotas for agriculture, mining, commerce and transport. Seychelles has quotas for the manufacturing sector in free trade zones. Sweden has quotas in agriculture. Other countries either apply quotas to specific occupations (as in Belarus, Mexico, New Zealand and Spain), or use a combination of these criteria. Only a few countries have quotas that also specify the countries from which the workers may come, mainly as a consequence of bilateral agreements; this is the case in Algeria, the Czech Republic, Guatemala, the Republic of Korea, Singapore, Slovakia, Spain and Switzerland. Quotas are usually not applied to countries of origin. In the International Labour Migration Survey, only 12 countries indicated that they applied such quotas.

\footnotetext{
${ }^{3}$ See M. Ruhs: Temporary foreign worker programmes: Policies, adverse consequences and the need to make them work (Geneva, ILO, Social Protection Sector, Perspectives on Labour Migration, No. 6, 2003).
} 
381. Switzerland has tried various ways of setting quotas. In the 1940s and 1950s it used the principle of rotation; in the 1960s it applied enterprise quotas; in the 1970s it used the double platform of enterprise and sector quotas; and in the 1980s and 1990s it set a global ceiling. In 1999, after entering into a bilateral agreement with the EU on the free movement of persons, Switzerland adopted a dual system: EU/EFTA nationals will be subject to preferential quotas during a transitional period at the end of which quotas will be lifted, while nationals of all other countries will face more restrictive conditions for residence and access to the labour market. ${ }^{4}$

\section{Box 6.2}

\section{Different ways in which quotas are expressed}

Quotas may be expressed in absolute numbers or as percentages - of the total population, total labour force, or labour force in a given sector or enterprise. In Austria, the limit is 8 per cent of the labour force (up to 9 per cent for certain categories), while in Honduras the maximum is 10 per cent. In the United States, the H1B and H2B visas are covered by annual quotas established by federal law.

Some countries fix the quota at the level of the enterprise. For example, Mauritius allows a maximum of one foreign worker for every three local workers; Ecuador allows one for every five local workers. Bolivia allows migrants to comprise 15 per cent of the enterprise workforce, while Egypt and El Salvador set the proportion at 10 per cent. Tunisia puts a numerical cap of only four foreign workers per enterprise, which must be totally export-oriented.

382. The quota system can be somewhat inflexible. During periods of economic contraction there is always the option of not using the full quota, but during periods of expansion the quotas cannot be quickly adjusted upwards. Nevertheless, a quota presents strong advantages: it provides a clear framework for the debate on immigration policy and it offers a clear benchmark and a transparent guide for administrators and employers.

383. Finally, in order to ensure that workers actually leave the country after the termination of their employment, some countries also require that employers put up a deposit as a guarantee - as in Bahrain, Cyprus, Iceland, Kazakhstan, the Republic of Korea, Lebanon, Malaysia, Mauritius and the United Arab Emirates. Mauritius, for example, bases these deposits on the outward economy class air ticket from Mauritius to the sending country. Colombia does not require any deposit but requires employers to include in the contract a provision regarding the unconditional return of the migrant worker.

\subsection{Path dependence in migration policy}

384. Migration policy is one area where future decisions are constrained by past decisions - there is strong "path dependency". This is because, unlike the movement of goods, the movement of people is difficult, indeed often impossible, to reverse. Even changes in economic circumstances may have little effect on migration flows, since migration can respond to economic cycles in an asymmetric fashion, increasing on the upswing but not necessarily falling on the downswing. In East Asia, for example, most countries established temporary or guest worker programmes based on the idea of using

\footnotetext{
${ }^{4}$ See W.R. Böhning: Employing foreign workers: A manual on policies and procedures of special interest to middle- and low-income countries (Geneva, ILO, 1996).
} 
migration to stabilize wages during peaks in economic activity, and the plan was that, during a downswing, migrants whose work permits had expired would leave. However, return seldom takes place in this fashion, especially among migrants in an irregular situation, in part because they do not want to leave but also because employers want them to stay. Even when unemployment is rising employers can find it difficult to recruit national workers for certain jobs, and may be reluctant to raise wages to tempt them.

385. More generally, however, although migration may respond to underlying economic differences between source and destination countries, it does not necessarily respond closely to economic fluctuations. Thus, while migration flows to Germany, the Netherlands, Sweden and the United Kingdom, and to a lesser extent Australia, appear to have moved in parallel with the business cycle until the end of the 1970s (figure 6.1), such links were not evident in Canada and the United States, and from the 1980s onwards no countries demonstrated a relationship between migration and economic growth. ${ }^{5}$

386. Many countries, developed and less developed, have temporary admission policies whose rules are linked to local needs and circumstances, as when migrants in agriculture, forestry or tourism are limited to stays of three to nine months. The United States, for example, gives sheepherders with the H2A seasonal agricultural worker visa the option of renewing for a total length of stay of up to three years.

387. In other countries the link between labour demand and the length of stay is less clear, since the duration of admission can vary considerably according to workers' skills, the needs of employers, and the country of origin. Brazil, for example, gives 90-day visas to technicians, but two-year temporary visas to those admitted as part of technology exchanges. Canada determines the time limit for temporary workers according to the needs of the employer, and may require a reassessment of the need for foreigners before renewal. Australia offers temporary skilled migrants a range of multiple-entry visas for employment and business purposes for up to four years with the option, subject to certain criteria, of renewal beyond this period. Senegal grants 24month visas that may be renewed on the basis of an employment contract. Member States of the EU offer nationals of other Member States preferential access to their labour markets, but individual governments can also enter into treaties with non-EU countries. For example, Greece in 2003 granted six- to nine-month work permits to Egyptians employed in the fishing sector, and permits of up to six months for seasonal workers from Albania and Bulgaria.

388. Path dependence in decision-making is observed not only in destination countries but also in source countries where governments have taken a more proactive role in sending their workers abroad. Pakistan, the Republic of Korea, and the Philippines, followed later by most other Asian countries, established government-funded programmes to recruit people to work overseas, notably in the Gulf States. This triggered the growth of a new "migration infrastructure" in the form of recruitment companies, labour and construction contractors, travel agencies, schools and training centres, and medical clinics for health certification - along with remittance agents and foreign exchange brokers to transfer funds home. These companies can constitute a multi-billion dollar industry that has a strong vested interest in the continuation of labour migration.

\footnotetext{
${ }^{5}$ See OECD: Employment Outlook 2001 (Paris, June 2001), Ch. 5.
} 
Figure 6.1. Net migration rate and the business cycle in selected OECD countries (1960-95)
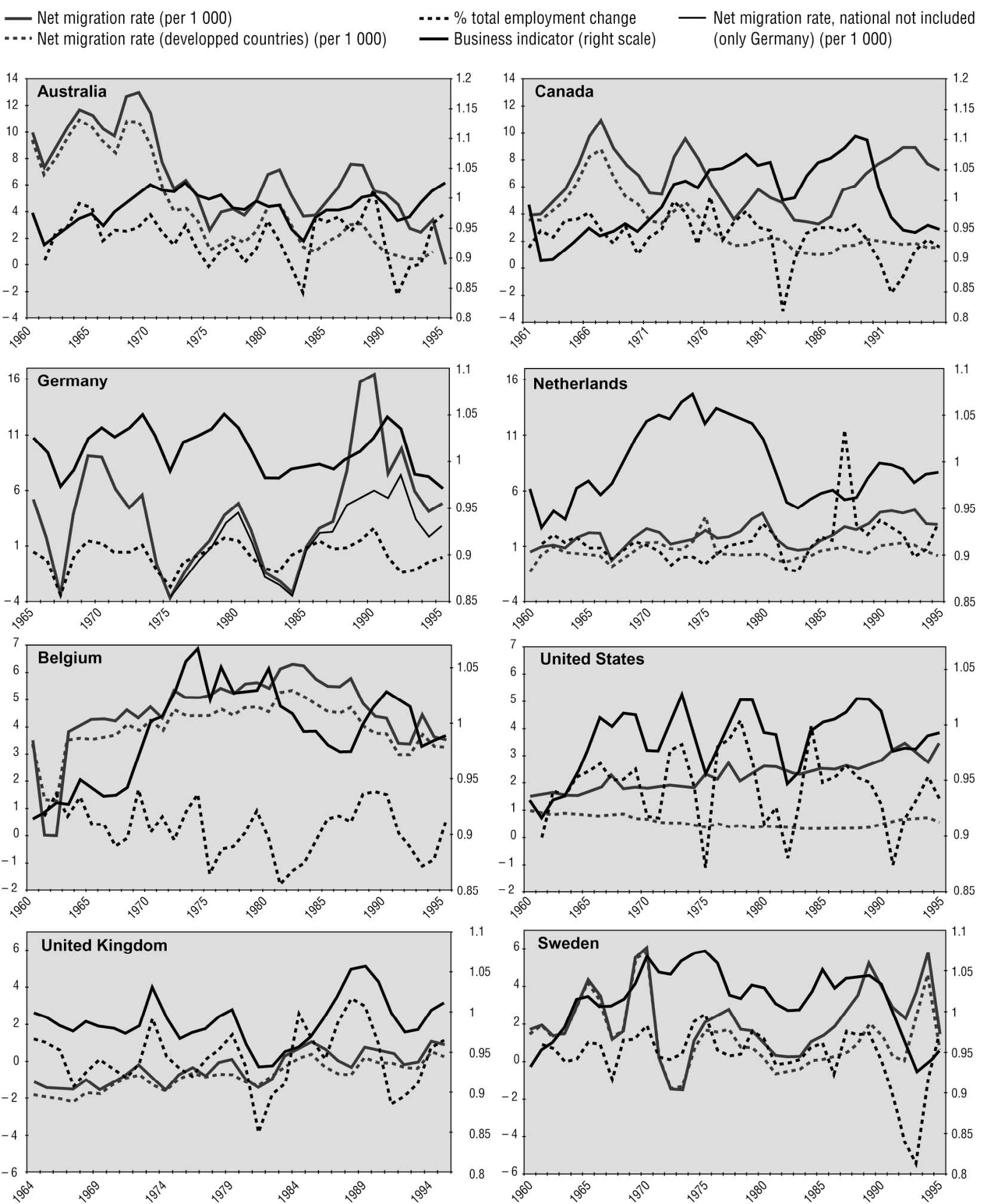

Sources: Labour Force Statistics (OECD), calculations by the OECD Secretariat; Population Division (United Nations). 


\subsection{Making temporary migration schemes work}

389. There is a convergence of interests of origin and destination countries in temporary labour migration, but conventional guest worker programmes have come under considerable suspicion. The experience of many countries is that "there is nothing more permanent than temporary workers". Governments that have seen their policies frustrated because of this have therefore been reluctant to liberalize the employment of temporary foreign workers - whether through the usual guest worker programmes or the "Mode 4" initiatives under the General Agreement on Trade in Services (GATS).

390. The drift from temporary to permanent migration responds to the wishes of both employers and workers. Employers become dependent on such workers, who not only settle for lower wages than native workers but are also less likely to leave for better alternatives. Workers, too, may want to stay longer to recover the funds they have invested in migrating or to reach their desired savings target - particularly when the alternatives at home remain unattractive. If they see that enforcement is weak and that there is a secondary market that will offer them work, they may take the risk of extending their stay indefinitely and disappearing into the ranks of irregular workers, where they are also less easy to identify and may find it easier to overstay.

391. On the other hand, the prolongation of temporary worker programmes can also be a predictable consequence of policies that have allowed labour market segmentation. In the Gulf States, for example, wages are higher in the public than in the private sector as a consequence of liberal admission policies that have driven private sector wages down; as a result, national workers prefer to remain unemployed rather than accept jobs in the private sector. This problem has been compounded by a recruitment system involving local "sponsors" or khafeels, who have profited handsomely from bringing in more workers regardless of their employment prospects. Swelling the labour market with migrant workers and thereby lowering wages may have benefited consumers and reduced the cost of public subsidies, but its long-term consequence is dependence and greater difficulty in providing jobs for local workers.

392. If they are to be successful, temporary work programmes must recognize that some people will move from being temporary to being more permanent, and governments must provide for such an eventuality. At the same time, the schemes must work, and be seen to work, otherwise they will be perceived as policy failures. Experience suggests some possible options. One strategy is to have a more open dialogue and closer cooperation between source and destination countries - through bilateral agreements that provide for greater state involvement in the migration process and can ensure more orderly admission and return of workers. Another approach is to use contract labour migration organized through carefully selected private contractors, although this tends to be confined to certain occupations like construction. Project-tied contract labour migration to the Gulf States, for example, saw millions of workers come and go for short periods of employment during the two decades of the construction boom that followed the oil price increases of 1973.

393. Complementary measures have been used to make temporary migration policies work. One is a system of "forced savings" in lieu of social security taxes. These are deposited with the social security institution, either of the host or the origin country, to be recovered when the worker goes home. The migrants risk losing such savings if they do not return after completion of their contracts. An objection often raised against forced savings is that they make it more tempting for temporary workers to switch early to 
illegal employment, since the longer they stay in legal employment the more savings they are likely to forfeit.

394. Some governments put the onus on employers to ensure that workers return. Greece and Israel, for example, require employers to post a bond that is forfeited if the worker fails to leave at the end of his or her contract. ${ }^{6}$ This encourages employers to offer better conditions and wages so that the workers are less tempted to switch to illegal employment. In the case of Israel, the policy was complemented by a requirement that a foreign worker who finishes a legal employment of five years must leave the country for at least a year before he or she can return. ${ }^{7}$ This combination of employer bonds and mandatory returns after a period of employment seems to have had some success.

395. The most common approach is to apply sanctions against employers who employ irregular workers. In principle such sanctions should decrease earnings in illegal employment, since employers who risk such penalties would not pay irregular workers as much as regular workers. Whether or not the policy will produce the desired effects, however, depends on a credible threat of prosecution. The experience with this has been mixed. ${ }^{8}$ In the United Kingdom, for example, the Asylum and Immigration Act (1996) makes it illegal for employers knowingly or negligently to employ people who do not have permission to work. The maximum penalty is $£ 5,000$ for each illegal employee. But prosecutions have been few - only one in 1998, nine in 1999, and 23 in 2000.

\subsection{The need for a comprehensive approach to irregular migration}

The public has been fed images of a flood of unwelcome entrants, and of threats to their societies and identities. In the process, immigrants have sometimes been stigmatized, vilified, even dehumanized. In the process, an essential truth has been lost. The vast majority of migrants are industrious, courageous, and determined. They don't want a free ride. They want a fair opportunity. They are not criminals or terrorists. They are law-abiding. They don't want to live apart. They want to integrate, while retaining their identity.

Kofi Annan, Secretary-General of the United Nations, addressing the European Parliament on 29 January 2004.

396. Irregularity accounts for most exploitation of migrant labour, and the problem is growing. Irregular migration is now much higher than in the 1980s and estimated to be running at 5 to 20 per cent of aggregate annual admissions to the OECD countries - a result of many developments, including the growth of informal employment, widening wage differentials, porous borders, weak asylum systems, and the growth of smuggling. Irregular migration is even more pervasive in the developing regions. For example, in the late 1990s, South Africa had about half a million irregular workers. ${ }^{9}$ In 1997, the

\footnotetext{
${ }^{6}$ G.S. Epstein, A.L. Hillman and A. Weiss: "Creating illegal immigrants", in Journal of Population Economics (European Society for Population Economics and Springer Publishers, 1999), 12(1), pp. 3-21.

${ }^{7}$ For a full analysis of the impact of policies on contract temporary migration, see Ch. 6 of T. Boeri, G. Hanson and B. McCormick (eds.): Immigration policy and the welfare system - A report for the Fondatione Rodolfo Benedetti (Oxford, Oxford University Press, 2002).

${ }^{8}$ P. Martin and M. Miller: Employer sanctions: French, German and US experiences (Geneva, ILO, International Migration Branch, International Migration Paper No. 36, 2000).

${ }^{9}$ J. Crush and V. Williams (eds.): "Criminal tendencies: Immigrants and illegality in South Africa”, Migration Policy Brief No. 10, Southern Africa Migration Project.
} 
authorities in Thailand estimated that they had close to 1 million irregular migrants from neighbouring countries, especially Myanmar.

397. Migrants can acquire irregular status in many different ways. They may enter a country illegally, either by avoiding border controls completely or by entering with false documents. Even if they enter legally, they may overstay their visas and thus become illegal residents. Or they may have entered on a non-working visa and then started to work; in some countries, this may make the entry illegal retroactively, since the act of seeking or accepting work is construed as deception of the authorities upon entry - by posing as a tourist or student while intending to work. This can also happen when people are allowed in under family reunification schemes, since in some circumstances they are not supposed to work. Furthermore, even if they are allowed to work, migrants may jeopardize their right of residence if they breach tax or social security regulations, although compliance with these regulations is often primarily, or customarily, the employer's responsibility. Temporary workers also acquire irregular status if they stay beyond their allocated time, and unsuccessful asylum seekers who have not been deported may also stay on as irregular workers.

398. Repatriating irregular migrants is often difficult, either because of legal norms or the lack of administrative resources. Governments committed to protecting human rights, including the right to family life, will find it difficult to expel migrants who have strong social and family ties in the country. They may also be unable to expel migrants if they cannot find another country that is willing to accept them back, or if they cannot obtain transportation to the country of origin (or to a safe part of the country). In 1997, for instance, the Parisian police questioned an average of 100 undocumented migrants daily, only to release 80 of them within an hour owing to shortage of places in detention centres or because they could not be returned..$^{10}$ In practice, only small percentages of asylum applicants and migrants whose applications are not granted are ever removed. In many cases, authorities have ordered migrants to leave the country but never enforced the decision, leaving the migrant in a state of irregularity for five to ten years or even longer.

399. Countries would be better off regularizing the status of workers whom they cannot send back home. This benefits not only the migrants but the country as a whole. In this connection, a principle that seems to have wide implicit resonance in the regularization policies of many countries is that of earned adjustment. Migrant workers with irregular status may be said to earn a right to legal status if they meet certain minimum conditions: they must be gainfully employed, they must not have violated any laws other than those relating to illegal or clandestine entry, and they must have made an effort to integrate by (for example) learning the local language.

400. Large numbers of irregular migrants create significant problems, both for the migrants themselves and for the host countries. Migrants in irregular status, who cannot stand up for their rights, often suffer exploitative working conditions and have little access to social security. They may also represent unfair competition for regular workers, provoking resentment and thus endangering social cohesion. In the worst cases they end up staffing the underground economy and become involved in criminal activities.

\footnotetext{
${ }^{10}$ P. Weil: "Towards a coherent policy of co-development", in International Migration, Vol. 40(3), Special Issue I, 2002.
} 


\section{Box 6.3}

\section{Combating irregular migration and the illegal employment of foreigners (Contributed by the OECD, Paris)}

Combating illegal entry, residence and employment of foreigners is one of the key priorities of the immigration policies of OECD countries. It is shared by all the European OECD countries, including the new immigration countries (Italy, Spain, Greece and Portugal), by the Asian member States, where many foreign nationals remain beyond their allotted time, as well as Australia, the United States and Canada. The terrorist attacks against the United States in September 2001 have considerably increased such concerns in the majority of OECD countries.

Illegal immigration exists only where restrictions exist alongside a certain degree of tolerance. It reflects an imbalance between the number of would-be emigrants and the restrictions placed on new entrants by host countries. Irregular migration and the illegal employment of foreigners are related. Generally speaking, the objective of undocumented migrants is to work in the host country, all the more so since this will enable them to pay off their debts to traffickers.

Although migrants may gain certain advantages from illegal employment, they rarely make a deliberate choice to be in an illegal situation. During regularization procedures, the eagerness displayed by most of those who qualify to make an application shows that undocumented persons would prefer to have legal status. Similarly, the argument that illegal workers (more interested in potential earnings than conditions of work) are prepared to accept longer hours of work needs to be qualified (Dunn, 1990).

The advantages of illegal migration are in fact more apparent for certain employers, who may have an interest in the illegal resident status of such migrants which puts them in a particularly dependent situation. Moreover, the fact that the work carried out by these migrants is undeclared enables employers to avoid paying taxes. Of course, the scale of illegal employment of foreigners is a reflection of undeclared employment in general, which is itself a result of the tax burden placed on enterprises, as well as the frequency of inspections and the type of penalties incurred. Nonetheless, during periods of immigration restrictions, the legal entry of temporary workers can be used as a means to counteract the employment of undocumented foreigners (OECD, 1999).

\section{Combating the illegal employment of foreigners}

OECD countries have implemented an array of measures to combat illegal immigration and the illegal employment of foreigners. These measures can be put into five categories:

a Controlling migration flows through border and internal controls as well as visa policies.

- Combating networks involved in the trafficking and exploitation of human beings by imposing severe penalties or offering special visas to anyone who testifies against traffickers.

a Controlling the number of undocumented persons through deportation procedures and regularization programmes.

- Monitoring the labour market and imposing administrative, criminal and civil sanctions against employers, contractors and undocumented migrants.

- International cooperation between host countries as regards policing, or with sending countries.

Although controlling the entry of migrants is essential, it is not generally in itself sufficient for combating the illegal employment of foreigners, on the one hand, or for reducing the number of undocumented migrants, on the other. As observed in some European countries in the late 1970s, strengthening external controls can actually slow down return rates, consolidate family reunification and therefore increase the length of stay in the host country and the number of documented and undocumented foreigners. 
A comparative analysis of the policies implemented in OECD countries in the area of prevention of and combating illegal employment of foreigners (OECD, 2000) emphasized the need to combat undeclared work in general and to consider a combination of sanctions - which are not always effective, are difficult to impose and have a negative effect beyond a certain threshold (Hill and Pearse, 1990; Fraser, 2000) - and nonrepressive preventive measures. The risks and sanctions incurred for using an illegal labour force should be made clear to employers and workers in sectors where such practices are commonplace, and also to employers who occasionally use undeclared labour and to sending countries. Some specific measures that have been adopted in several countries, including systems for declaring workers prior to employment, financial incentives for employing documented workers or even a simplification of recruitment procedures, could be applied in more countries.

The policies implemented must also take into account the fact that undocumented foreigners are particularly vulnerable owing to the precariousness of their status - they do not have the right to work in the host country, and in most cases do not have the right to take up residence there. Lastly, it should be noted that strengthening international cooperation in this area is becoming increasingly urgent. No country can claim any longer to be effectively combating single-handedly the problem of illegal immigration and trafficking networks, which are increasingly active and professional.

Sources: D. Delaunay; G. Tapinos: La measure de la migration clandestine en Europe, Vols. 1 et 2, Rapport de synthèse et études par pays, Eurostat Working Paper No. 7, 1998.

L.F. Dunn: "An empirical study of labour market equilibrium under working hours constraints", in Review of Economics and Statistics (Cambridge MA, MIT Press), Vol. 72, No. 2, May 1990, pp. 139-157.

OECD: Trends in international migration (SOPEMI edition, 1999). See especially the chapter on the economic and political implications of irregular immigration.

OECD: Combating the illegal employment of foreign workers (Paris, 2000).

J.K. Hill; J.E. Pearse: "The incidence of sanctions against employers of illegal aliens", in Journal of Political Economy (Chicago, University of Chicago Press), Vol. 98, No. 1, 1990, pp. 28-44.

J. Fraser: "Preventing and combating the employment of foreigners in an irregular situation in the United States", in Combating the illegal employment of foreign workers, OECD, op. cit.

401. Faced with large numbers of irregular migrants, governments frequently choose to declare amnesties through which migrants can regularize their status. ${ }^{11}$ Regularization programmes are complex undertakings. Authorities must convince the migrants that it is to their advantage to become regularized, but they cannot divulge their plans too far in advance, since this might immediately encourage more immigration. They must prepare the ground carefully and ensure that they fully involve representatives of all the groups that will be affected. They also have to engage the migrants themselves using publicity and information programmes through channels that migrants trust. Some governments have found that a good way to achieve this, and generally overcome suspicion, insecurity and resistance, is to engage the help of a range of civic and religious organizations.

402. Regularizations also work best when the process is straightforward. If the requirements are too demanding, time-consuming or costly, they will discourage many of those who are eligible. Regularization should instead take the form of a simple act at the lowest possible level of administration, demanding very little documentation and requiring neither the support of a lawyer nor recourse to the courts. In some countries, it is not the workers who have to register but their employers. Since some of the latter may gain from paying wages below the legal minimum, they may not be motivated to register their workers.

\footnotetext{
${ }^{11}$ P. de Bruycker (ed.): Regularisations of illegal immigrants in the European Union (Brussels, Bruylant
} Editions, 2000). 
403. Many regularizations are treated as a one-off exercises - brief "windows of opportunity" offering a large number of migrants the opportunity to regularize one or more aspects of their status. When it is repeated, the determination of the government comes into doubt. The alternative is to have a permanent national authority with powers to regularize the status of irregular migrants who submit a petition and fulfil established criteria.

404. It is clear that a comprehensive approach to irregular migration requires a combination of measures. These will include law enforcement, the creation of a conducive legal and administrative environment, and the provision of incentives. But none of these will be sufficient in isolation. In the United Kingdom, for example, a recent White Paper $^{12}$ articulates a more consistent and integrated policy that will include immigration, integration and citizenship.

\subsection{Regulating labour migration in countries of origin}

405. All democratic States guarantee for their citizens the right to accept offers of employment in foreign countries. Only a few have laws or regulations that empower the authorities to intervene in the contracts of individual migrants. However, the extent of abuses suffered by their workers abroad has brought some governments under immense public pressure to regulate labour migration for the protection of the migrants.

406. The International Labour Migration Survey revealed that most governments have taken on one or more regulatory functions related to labour migration, including:

- setting, monitoring and enforcing standards in national constitutions, laws and regulations;

- providing public employment services, and/or regulating and supervising private recruitment agencies;

- adopting and applying model employment contracts;

- taking specific measures against trafficking and smuggling;

- $\quad$ arbitrating in disputes between migrant workers and their foreign employers;

- creating national and regional institutions for enforcing human rights;

- regulating the employment of migrant workers and managing migration flows between and among countries through multilateral agreements. ${ }^{13}$

407. Countries of origin have little control over the terms and conditions of employment of their nationals in other countries. But they can at least try to ensure that migrants are well informed, so that they do not accept disadvantageous employment offers in ignorance of the risks involved, and can inform prospective migrants about the conditions they are likely to face, particularly on the standard and cost of living.

408. Those governments that are empowered to supervise the recruitment and employment of their nationals abroad can also take more specific measures before their

\footnotetext{
${ }^{12}$ Home Office: Secure borders, safe haven: Integration with diversity in modern Britain (London, HMSO, 2001).

${ }^{13}$ For a full discussion of the best practices on regulating emigration processes in countries of origin, see M. Abella: Sending workers abroad: A manual for low- and middle-income countries (Geneva, ILO, 1997).
} 
citizens leave the country. They can, for example, establish regulations on minimum standards for employment - covering wages, hours of work, holidays, overtime pay, home leave, employment injury insurance, and termination arrangements. They can also supervise the issue of employment contracts. One option is to prepare model contracts which can minimize disputes and problems, especially if the contracts are realistic and endorsed by the authorities in the receiving country. The authorities can also use such contracts to ensure that before they sign them, migrants fully understand their rights and obligations. Governments in the countries of origin can also insist that all contracts be approved by a competent authority, usually the ministry of labour.

409. To make these measures more effective, however, the authorities also have to disallow the employment of their nationals in countries that do not respect their standards. This can be a difficult issue, particularly if it is likely to seriously restrict the number of overseas employment opportunities. In table 6.1, the policies and measures that have been adopted by countries to protect their workers while seeking more employment opportunities abroad have been mapped under three major objectives:

- promote employment;

- $\quad$ protect and promote the well-being of migrants;

- maximize developmental impact of labour migration.

Table 6.1. Foreign employment policy map

\begin{tabular}{ll}
\hline Objectives & Policy instruments and measures \\
\hline Promote employment & Foreign market development \\
& $\square$ Establishing diplomatic relations \\
& $\square$ Strengthening placement services, public and private \\
& $\square$ Promotions and marketing missions \\
& $\square$ Market information and research \\
& $\square$ Bilateral agreements \\
& Labour supply management \\
& $\square$ Labour registry \\
& $\square$ Corporate export of services \\
& $\square$ Restrictions/policies against "brain drain"
\end{tabular}

Protect and promote the well-being of migrants
Standard setting and enforcement

a Minimum standards for employment contracts

- Exit control measures

- Bilateral agreements including social security

Restrictions on exit of selected categories of workers, especially minors and young women

Supervision of private recruitment

- Licensing of recruitment firms

- Performance guarantees and penalties 


\begin{tabular}{|c|c|}
\hline Objectives & Policy instruments and measures \\
\hline & Limits on recruitment fees \\
\hline & $\begin{array}{l}\text { Measures against illegal recruitment and clandestine } \\
\text { migration }\end{array}$ \\
\hline & Support services \\
\hline & Information and counselling services prior to departure \\
\hline & Labour attaché services on-site \\
\hline & Social insurance \\
\hline & Community facilities and centres for workers abroad \\
\hline & Support services for families left behind \\
\hline & Returnee training and employment assistance \\
\hline & Emergency evacuation or repatriation \\
\hline \multirow[t]{11}{*}{ Maximize developmental impact of labour migration } & Remittances \\
\hline & Foreign exchange market policies \\
\hline & Remittances policies and services \\
\hline & Migrants' savings and investments \\
\hline & Special financial instruments \\
\hline & Information and support services to small investors \\
\hline & Housing programmes for migrants \\
\hline & Return of talents and skills \\
\hline & Special placement services and incentives \\
\hline & Bilateral training agreements \\
\hline & Mobilizing transnational communities \\
\hline
\end{tabular}

Source: M. Abella: Sending workers abroad: A manual for low- and middle-income countries (Geneva, ILO, 1997).

410. Only a few countries require that recruitment for foreign jobs be done through public employment agencies, possibly because these may not be adequately equipped for this responsibility. However, most countries have competent state authorities that are empowered to review and approve work contracts, prosecute violators of recruitment regulations, or arbitrate disputes between migrant workers and foreign employers or agents. This is the case in Albania, Brazil, China, Ethiopia, Madagascar and Senegal. Most of these authorities are also empowered to enter into agreements with foreign employers or to recruit nationals for employment abroad. Thirty-five of the countries that responded to the International Labour Migration Survey stated that they had specific provisions regulating the contractual provisions of migrant workers leaving their countries. In Latin America, many governments do not have the power to license private recruitment agencies but are able to prosecute for recruitment malpractices.

\section{Protecting workers against recruitment fraud and abuses}

411. Most countries of origin require private enterprises wishing to engage in fee-based recruitment to obtain a licence from the competent authority. This is the most important policy instrument for instilling order in the industry. By setting stringent conditions for a licence, the authorities can limit recruitment to companies that have the know-how and 
resources to find good employment opportunities. They can then cancel or suspend licences for serious violations of recruitment regulations. Some governments have also had well-intentioned policies such as limiting the validity of a licence to a very short period like one year. But this can produce undesired consequences - discouraging legitimate operators, while attracting those only interested in quick profits.

412. Licensing will only work, however, if the authorities can prevent the operation of unlicensed recruiters. This requires the involvement of all levels of government, from the national authority at the centre to the lowly village head at the periphery. They should also be able to rely on the support of many other institutions, from the police to church groups. In addition, the public need to be provided with up-to-date information on which are the authorized or licensed agents, and what services they should expect from them.

413. Successful administration needs to be backed up with appropriate legislation. One significant innovation is a law in the Philippines which establishes that, in the case of a violation of an employment contract, the recruiters and the foreign employer are jointly liable. Recruiters are also required to put up large performance bonds. These measures have put the onus on the recruiter to take care when choosing foreign employers, and have made it much easier for the Philippine Overseas Employment Administration to settle workers' financial claims.

414. One of the most difficult tasks in supervising recruitment is to control recruitment fees, since workers seeking to beat the long queue are willing to pay additional sums. Market-determined fees tend to be higher when there is a large wage differential between the source and the destination country: for the same job in the same country, workers coming from lower-wage countries appear to pay more in fees than those from higherwage countries. The fees also tend to be higher for low-skilled workers; those whose skills are in great demand, like nurses and IT workers, may not be charged any fees, even if the wage differential is huge. In response to widespread abuse, most Asian countries of origin have set a ceiling on fees.

415. According to the International Labour Migration Survey, of the 40 countries where private recruitment agencies are permitted to bring in migrant workers, some 23 allow them to charge recruitment fees from the workers. These include developed countries such as Canada, Switzerland, the United States and New Zealand (with reservations). Other countries that allow recruitment fees to be levied are Algeria, Bahrain, Burundi, China, Kazakhstan, Malaysia, Mauritius, Seychelles, Slovakia, Suriname and Tajikistan. In most cases, however, governments limit the fees. In Malaysia, for example, fees may not exceed 25 per cent of the first month's wages, while in Japan they may not exceed 10.5 per cent. In Mauritius, the ceiling is 10 per cent of the first month's wages, while in Switzerland it is much higher, at 5 per cent of the worker's annual wages.

416. However, enforcement can be difficult and compliance tends to fall when there is a large wage differential at times of high unemployment. Compliance also depends on the levels of education of the workers as well as the vigilance of the public.

\subsection{Advantages of inter-country cooperation}

417. Destination countries are increasingly realizing that they have few ways of influencing "unwanted" migration unilaterally. This insight, though often unacknowledged, has now resulted in a host of cooperative efforts on migration management, most of them at the bilateral level, many at the regional level, and some at 
the global level. This cooperation deserves to be strengthened as it has significant potential.

418. International cooperation can consist of a variety of measures, some of them preventive, others remedial. As part of regional economic integration, along with reducing barriers to free trade, countries can conclude agreements for the free movement of labour. Destination and source countries can also enter into bilateral agreements on recruitment and employment, and cooperate in the management of return programmes.

419. Promotion of a normative framework for national policy and international cooperation remains a fundamental task. There is a need for an international regime based on the rule of law, that establishes common parameters for all, clear accountabilities, and mechanisms for reporting and monitoring. The framers of the ILO Conventions on migrant workers (Nos. 97 and 143) envisaged such cooperation and made provision for the reciprocal exchange of information on national policies, laws and regulations, migration for employment, the conditions of work and livelihood of migrants for employment, and on misleading propaganda. Convention No. 143 also provides for cooperation between States with the specific aim of suppressing clandestine movements of migrants for employment, acting against organizers of the illicit movement of migrants and those employing workers who have entered illegally, and ensuring that the authors of labour trafficking can be prosecuted, regardless of the country from which they exercise their activities.

420. International cooperation should also have an important role for the social partners. Not only are they major agents of social, economic and political change at home; they also have international forums that can be used to initiate or orchestrate international cooperation between States. At the same time it must be recognized that migration management through States, or with the help of the social partners, can only go so far. Authorities find it difficult to make people conform perfectly to any set of objectives on migration or any other policy area. Rather than simply trying to manage people, a better approach is to involve them in the making of policies that affect them.

\section{Aid and remittances}

421. Governments in the destination countries might also consider helping to reduce migration pressure in the source countries through development aid targeted at increasing employment opportunities and improving the levels of human capital. In 1993, the ILO and UNHCR convened an international meeting on "development aid and migration". This concluded that in some cases aid could indeed produce the growth that would stem emigration pressures. France in particular has accepted this principle through its "co-developpement" policy. Since 2000, for example, the annual Mali-France Consultation on Migration has dealt with the integration of Malians who want to stay in France, co-management of migration flows, and cooperative development in emigration areas of Mali. ${ }^{14}$

422. Migration itself can be a form of aid, particularly through remittances which are often the largest and most effective form of financial aid from abroad, since remittances go directly to households for their most immediate needs. But the benefits go beyond individual households since some groups of migrants also organize clubs in order to

\footnotetext{
${ }^{14}$ S. Martin; P. Martin; P. Weil: "Fostering cooperation between source and destination countries" (Migration Policy Institute, Oct. 2002); available online at www.migrationinformation.org (accessed on 10 Mar. 2004).
} 
invest jointly in their home community - in amenities such as schools, sanitation and health-care facilities, or mains electricity supplies.

423. But all this depends critically on being able to remit the funds reliably, swiftly and without undue interference or cost. Remittances will have a more positive effect if the economy of the migrant's home country is sufficiently open and flexible, with wellfunctioning markets for goods, services and foreign exchange, and with a legal system that protects property and other rights.

\subsection{Multilateral processes}

424. States voluntarily limit their sovereignty by making binding commitments in international law to regulate trade and migration, as with:

- Multilateral treaties and agreements. These include the ILO and United Nations Conventions already discussed in Chapter 4, which are international treaties with specific monitoring mechanisms including scrutiny by independent experts and (in the case of the ILO) tripartite constituents.

- General Agreement on Trade in Services (GATS). Mode 4 of GATS for natural persons supplying services relates to conducting negotiations on the rights of natural persons to remain temporarily in a country in order to provide a service, be it qualified or not qualified. The principle of the most favoured nation treatment is applied, but it is not applicable to persons who try to obtain a permanent job, or to the conditions of obtaining nationality, residency or permanent employment. ${ }^{15}$ Unlike regional integration agreements, this agreement is aimed at the member States of the WTO.

- Regional integration agreements. The frameworks of the European Union, MERCOSUR, the Andean Community and NAFTA allow for free circulation, establishment and access to the labour market of nationals from member countries. In this type of multilateral agreement, migration is treated as just another variable of an integration process. For example, the European Council in its Seville meeting in 2002 concluded that every cooperation and association agreement concluded by the EU must contain a clause for the readmission of migrant workers in an irregular status.

- Bilateral migration agreements. These agreements between origin and destination countries usually aim to regulate flows and conditions of stay and employment of migrants. The International Labour Migration Survey revealed that a large number of countries have entered into such agreements, which include provisions on social security.

\footnotetext{
${ }^{15}$ As was indicated at the Expert Meeting on Market Access Issues in Mode 4 (UNCTAD, Geneva, 29-31 July 2003), most countries deal with Mode 4 in the same way as migration (temporary), there being few countries which establish specific mechanisms or methods for the temporary movement of persons under the GATS (see summary by the Chairperson in the report of the Meeting, Geneva, UNCTAD docs. TD/B/COM.I/64 and TD/B/COM.I/EM.22/3, 27 Nov. 2003). In the ILO International Labour Migration Survey, 2003, only a few countries referred to their commitments under Mode 4 (for example, Austria, New Zealand and the United States).
} 


\section{Box 6.4}

\section{World Commission on the Social Dimension of Globalization Specific recommendations on migration}

"There is therefore a large and productive agenda for multilateral action. The issues and problems associated with the movement of people across national borders cannot be addressed by single countries acting in isolation or on a unilateral basis. To move forward on this agenda, we recommend action at three levels.

The first concerns international conventions and binding obligations. Building on the foundation of existing instruments, we believe that in several areas international consensus can be reached on the need to revitalize and extend multilateral commitments, including issues such as the basic rights and protection of migrant workers and their families, trafficking, discrimination and exploitation. Action on such issues needs to be taken within the multilateral bodies concerned, notably the ILO and the UN bodies concerned with human rights and crime prevention.

The second concerns dialogue between countries of origin and destination on key policy issues of common interest. Such dialogues could aim to develop and agree on procedures, recommendations and non-binding codes, complementing the formal obligations under ratified Conventions. This could begin on a bilateral or plurilateral basis, but it should extend to the regional level. Such dialogues should endeavour to:

a exchange information on surpluses and shortages of labour;

- develop coordination of policies among labour-exporting countries;

- create some harmonization of policies among labour-importing countries;

- work towards a regime of discipline to be imposed on intermediaries;

- build a more effective system for the prevention of trafficking in people;

a address the problems of illegal immigrants.

These dialogues could also help build common approaches to major policy issues such as the rules for temporary migration, the brain drain and the contribution of migration to development, and the alignment of social security and labour market policies; and develop an information system on such matters.

The third level would be to initiate a preparatory process towards a more general institutional framework for the movement of people across national borders. This means a transparent and uniform system, based on rules rather than discretion, for those who wish to move across borders. The ultimate objective would be to create a multilateral framework for immigration laws and consular practices, to be negotiated by governments, that would govern cross-border movements of people. This would be similar to multilateral frameworks that already exist, or are currently under discussion, concerning the cross-border movement of goods, services, technology, investment and information.

A global forum is needed for regular exchange of information and views on this issue among all the countries and interests concerned. Such a forum could help identify both problems and opportunities, and point to ways to ensure that the movement of people occurs on an orderly basis. It should engage not only governments but also both sides of the world of work. In Part IV we recommend a dialogue to develop policy on this issue in order to examine how best to develop this agenda.

Moving this agenda forward would imply strengthening the existing multilateral organizations dealing with the movement of people - notably the ILO, the International Organization for Migration (IOM), the United Nations human rights mechanisms and the United Nations High Commissioner for Refugees (UNHCR) - and improving the coordination among them. We welcome the initiatives under way such as the Geneva Migration Group and the proposed Global Commission on Migration established by the UN Secretary-General which is due to start work in early 2004 . We call on the ILO to take the lead on these matters and we look forward to the outcome of the general discussion on labour migration at the International Labour Conference in Geneva in 2004."

Source: World Commission on the Social Dimension of Globalization: A fair globalization: Creating opportunities for all, ILO, Geneva, 2004, paras. 440-446. 


\subsection{Bilateral migration agreements}

425. In the 1960s a number of European States facing serious scarcity of workers entered into bilateral agreements for the recruitment of labour. Most of these agreements ended during the 1970s as a result of economic crises, to be replaced by much looser framework agreements, memoranda of understanding and declarations of mutual cooperation on the contracting and protection of foreign workers. ${ }^{16}$ The $1990 \mathrm{~s}$, however, saw an upsurge in bilateral agreements. For example, of the 168 bilateral agreements concluded in Latin America in the second half of the twentieth century, half were concluded in the past decade. ${ }^{17}$

426. In the OECD countries, there are currently 173 bilateral agreements with countries from all regions of the world. As a result of the opening up of borders in Central and Eastern Europe, the number of bilateral treaties had increased fivefold by the beginning of the 1990s. ${ }^{18}$ The ILO's International Labour Migration Survey, 2003, also indicates considerable use of bilateral agreements by Central and Eastern European States and by the Commonwealth of Independent States, not only between States in the region or with neighbouring States of the European Union, but also with countries of southern Europe (such as Spain and Portugal) and even with countries on other continents.

427. Bilateral agreements which have followed ILO and other international models have proved to be an effective way of managing migratory flows. In fact, Recommendation No. 86 includes in its annex a model agreement on temporary and permanent migration of workers, which includes clauses on the regulation of migratory flows, working and living conditions, and social security for all. The International Labour Migration Survey found that Recommendation No. 86 has been widely used by States as a model, ${ }^{19}$ or will be used ${ }^{20}$ even by countries that have not ratified the ILO instruments.

\footnotetext{
${ }^{16}$ M. Abella: Sending workers abroad, op. cit.

${ }^{17}$ Between 1991 and 2000, 35 bilateral agreements were signed between Latin American countries (five for regularization, five labour conventions, 13 for free circulation and 12 for return). During the same period, 47 bilateral agreements were signed between Latin American countries and other countries (nine for readmission, one for regularization, five labour agreements, 18 for free circulation, 11 for return and three for migrant protection). The agreements for return include extradition treaties. See IOM: World Migration 2003, p. 178.

${ }^{18}$ A seminar on bilateral labour agreements was jointly organized by the OECD and the Swiss Government in Montreux, 19-20 June 2003.

${ }^{19}$ For example, by Argentina, Austria, Barbados, Colombia, Cyprus, Ecuador, France, Guatemala, Kenya, Republic of Korea, Lebanon, Mauritius, Myanmar, Portugal, Rwanda, Tajikistan, United Arab Emirates, Uruguay.

${ }^{20}$ Albania, Eritrea, Honduras, Kazakhstan, Madagascar, Poland, Slovakia, Togo.
} 


\section{Box 6.5}

\section{Bilateral agreements in Spain}

As part of its migration policy, Spain in 2001 adopted a "Global Programme" to regulate and coordinate foreign residents' affairs and immigration (the GRECO programme). The programme comprises five measures: (a) approval of criteria for the admission of immigrants; (b) calculation of the need for temporary or permanent workers; (c) determination of the countries with which to negotiate agreements; (d) management of all aspects of migration; and (e) establishment of mechanisms to select and, as necessary, train foreign workers in the source countries, with the contribution of the social agents and NGOs.

Spain has subsequently concluded eight bilateral agreements - with Morocco (1999), Colombia, the Dominican Republic and Ecuador (2001), Poland and Romania (2002) and Guinea-Bissau and Bulgaria (2003). In addition, more than 40 other States have asked to sign bilateral migration agreements with Spain. Some of these countries, such as Argentina and Mexico, have a large number of Spaniards living in their territories.

The agreement concluded with Ecuador, for example, is intended to cover the whole of the migration process: the pre-selection of workers, the system of communicating job offers, the selection and recruitment of workers in the sending country, special provisions for temporary workers, the organization of travel, guarantees of labour conditions and rights at the destination, the possibility of family reunification, and provisions for return. In order to coordinate requests by its nationals who wish to work in Spain, the Ecuadorian authorities, in collaboration with the IOM, have set up the Technical Unit for the Selection of Migrant Workers.

\subsection{Regional economic integration and the free movement of labour}

428. Although international migration flows are becoming increasingly intercontinental, the largest flows are probably still those between countries in the same region. In the United States, a high proportion of migrants still come from Mexico and Central America; in Europe, migrants from non-EU countries tend to come from Eastern Europe, Turkey, the Balkans and the Maghreb; in Asia, some of the largest flows are from Afghanistan to Pakistan and the Islamic Republic of Iran, from Myanmar to Thailand, and from Indonesia to Malaysia; and in Africa, the most active migration systems are those between South Africa and her neighbours, between the countries of Central Africa, and between the countries of West Africa, where there are some 3 million migrant workers.

429. The European Union forms the most extensive area with free movement of labour, but agreements have also been concluded in many other regions: between members of the Nordic Community, for both skilled and unskilled labour; between Australia and New Zealand under ANZCERTA; between Canada and the United States (and Mexico from 2004) for skilled labour under NAFTA; between the member States of the Andean Community; among the CAEMC countries in Central Africa and UMEOA in West Africa; and between the Caribbean countries for skilled and unskilled labour under CARICOM. These agreements provide for progressive harmonization of labour policies with a view eventually to giving full equal treatment to one another's nationals. In the MERCOSUR area, an agreement on residence for nationals of States parties was adopted in December 2002. Interest in further advancing the integration process prompted Argentina's unilateral decision to suspend expulsions of irregular migrants originating from neighbouring countries in February 2004. The resolution in question concerns about 700,000 irregular foreigners from Brazil, Uruguay, Paraguay, Bolivia and Chile. 


\section{Box 6.6}

\section{The development of a common immigration policy in the European Union}

With the coming into force of the Treaty of Amsterdam in 1999, Community competence was established in the area of immigration and asylum. Following a decision of the European Council meeting in Tampere in October 1999, the European Union is committed to developing a common policy on immigration and asylum based on a number of principles. These are:

a a comprehensive approach which accepts there is a need to find a balance between humanitarian and economic admission and also acknowledges the policy links between the different aspects of migration and asylum and, therefore, the interaction between the measures put in place to deal with them;

a fair treatment for third country nationals, aiming to give them comparable rights and obligations to those of nationals of the Member State in which they live;

- the development of partnerships with countries of origin and of transit, including policies of co-development, as an important element in migration management strategies;

a a separate common policy for asylum which fully respects the terms of the Geneva Convention and Member States' obligations under international treaties, which should in the longer term develop into a common asylum procedure and a uniform status, valid throughout the Union, for those granted asylum.

Since 1999 the EU has been progressively developing these policies on the lines set out in Tampere and as subsequently elaborated by the Council on the basis of a series of policy documents put forward by the Commission. Progress has been made with the harmonization of national legislation on the admission and conditions of stay of third country nationals, with European directives already adopted on family reunion and on the status of long-term residents. EU legislation is still under discussion on admission for employment and self employment and for the purpose of study or to carry out volunteer work.

At the same time a considerable effort has been made to improve cooperation between Member States to reinforce control of the EU's external borders and to fight illegal migration, trafficking and smuggling more effectively. Action has been taken in a number of areas: visa policy; information exchange, improving cooperation and coordination between Member States' border authorities (which has led to an agreement to establish a European External Border Agency); police cooperation; and with respect to law on aliens and criminal law. Measures to combat smuggling and trafficking and to dismantle the networks involved have also been taken. Return policies have been strengthened and an EU return programme is to be set up.

Given the demographic decline and the ageing of its population which is forecast over the next decades, integration of immigrants is now one of the main challenges facing the Union. Within the context of the European Employment Strategy, immigration to meet the unfilled needs of the labour market is seen as one of the measures which will be necessary to enable the Union to meet the Lisbon goals for its economic development. The Commission published in June 2003 a communication on immigration, integration and employment which sets out proposals for reinforcing policy coordination, cooperation and the exchange of information and good practice with respect to integration.

An integral part of the European approach to migration management is to build closer relationships with third countries, and important efforts have been made to integrate migration-related issues into EU external and development policies. Issues concerned with migration management are now systematically introduced into the dialogue between the EU and countries of origin and transit, and other regional groupings (e.g. Mediterranean countries and Asian-Europe Meeting or ASEM) and it will be a key issue within the wider Europe framework. Since 2001 European funding has been $\mathrm{m}$ made available to support migration management projects in third countries. As a longer-term objective, particular importance is attached to the implementation of Council conclusions on migration and development adopted in May 2003 in order to tackle the root causes of migration flows.

Source: European Commission. 
430. These agreements reflect recognition of the economic and social advantages to be reaped in integrating labour markets. In providing a normative framework for the treatment of migrant workers, they also establish a basis for safeguarding their rights, especially where mechanisms for mutual reporting and monitoring can be agreed on. For this reason, regional agreements on migration may have a more direct bearing on how many people move and under what conditions than international treaties or conventions. Improving the management of migration and the conditions of migrants should therefore include measures to ensure more orderly movements between neighbouring States.

\section{Box 6.7}

\section{Contribution of regional processes to managing migration International Organization for Migration (IOM)}

In response to the increasing complexity and diversity of international migration, regional consultation mechanisms have developed around the world and have become an integral component of managing migration. There are currently 13 regional consultative mechanisms in place dealing with issues ranging from border control and entry to return and reintegration of migrants. They serve as mechanisms for bringing together representatives of States, international organizations and, where possible, nongovernmental organizations (NGOs) in order to discuss regional migration issues in a cooperative manner. Although they have an informal and non-binding nature, these processes serve to lay the foundations for common regional approaches to migration.

At their inception, regional processes tend to focus on ways in which origin, transit and receiving countries can work together to manage irregular migration flows. For this reason it is often the ministries of the interior and foreign affairs, rather than ministries of labour, that are involved. However, because of the growing awareness of the development benefits of migration, the agenda of regional processes have expanded beyond their focus on irregular migration to a wider range of issues, including labour migration. The number of regional consultative mechanisms has also grown significantly since their appearance in 1996. Below are some examples of regional processes and their work relating to labour migration.

The Regional Conference on Migration, or "Puebla Process", groups together the Central and North American countries and the Dominican Republic. Now in its eighth year, the Process had its first meeting in Puebla in March 1996 where the delegates agreed to work together to achieve 17 objectives. The countries have since agreed on a common Plan of Action. The Puebla Process is now moving towards technical cooperation and information sharing on a variety of issues, including common policies and practices on the return of regional and extra-regional migrants, joint training, and law enforcement exercises for combating irregular migration. With the establishment of a Liaison Officer Network for Consular Protection, it has been able to offer better consular protection and assistance to migrants.

As the first of its kind on the continent, the Migration Dialogue for Southern Africa (MIDSA) was created in 2000, in conjunction with the Southern African Development Community (SADC), to provide a forum for the exchange of information, experience and perspectives among governments on migration policy and practice, particularly on the intraregional movement of people. So far MIDSA has explored common themes such as border control and labour migration.

In West Africa, the Migration Dialogue for Western Africa (MIDWA) began as a followup process to the Dakar Declaration of October 2000. Under its auspices the governments of the region have received practical assistance in the design, implementation, and reinforcement of migration legislation and policies.

The $5+5$ Dialogue on Migration in the Western Mediterranean was launched in October 2002 in Tunisia. Its objective is the establishment of regular and informal discussions between five origin and five destination countries in the western Mediterranean on common migration issues and their linkages with regional cooperation and development. This resulted in the Tunis Declaration, which called for better management of legal migration and the integration of migrants. Since then it has had a second meeting in Morocco in 2003, and a third will take place in Algeria in 2004. 
In Asia, the IOM organized the Asian Labour Migration Ministerial Consultation for Sending Countries in April 2003 in Colombo. This was intended to start a series of ministerial-level consultations which would serve as a forum for Asian countries to share experience on how to manage labour migration and to agree on cooperative action. Twenty-two recommendations on the effective management of labour migration emerged from this first consultation. A follow-up meeting will take place in Manila in 2004.

To date there are few detailed studies assessing the performance and achievements of regional consultative processes. There is, however, a consensus that they can make a valuable contribution to the management of migration, notably through the sharing of information and experiences. The Puebla Process has been successful in enhancing cooperation to combat smuggling and trafficking and in ensuring more effective consular protection for citizens abroad. Enhanced cooperation in other areas, including labour migration, is clearly possible, and development issues are receiving heightened priority in regional dialogues today. Regional processes hold the promise of being an effective means for achieving closer inter-state cooperation in managing labour migration in the future.

Source: International Organization for Migration.

431. If governments are to make these agreements work, they have to harmonize policies and standards. But they also have to ensure that "gate-keepers" and administrators on the ground do not use their discretionary powers to defeat the objective of the policy. According to an ECOWAS Executive Secretariat Report in 2000, nearly all member States maintain numerous checkpoints and subject citizens to administrative harassment. There have been cases of expulsions from some countries in violation of agreements. A common problem is the lack of a common system for recognizing professional qualifications. Some countries retain barriers to entry into certain professions, requiring the passing of tests to obtain the requisite licences for applicants who are not educated in the country in which they work.

432. Regional economic integration through trade liberalization should eventually bring about a greater convergence of wages and prices and other factors of production - which in itself will reduce the incentive for migration. This has clearly happened in the European Union, which guarantees freedom of movement and equal treatment, and the portability of social welfare benefits. ${ }^{21}$ Despite this, foreign workers make up only 2 per cent of workers in the national labour markets of EU countries. Hence, regional economic integration ultimately brings about an apparent paradox: while it may open up greater possibilities for the free movement of labour, it also generates the kind of economic convergence that tends to reduce the need for such movements.

\subsection{Towards liberalizing trade in services}

433. If services are to be traded internationally, some workers will need to move temporarily to consumers' countries. The General Agreement on Trade in Services (GATS) that came out of the Uruguay Round in 1994 has already helped to facilitate such trade through agreements on the temporary admission of people who are engaged in rendering certain kinds of specialized service such as financial management and legal services.

434. This was a breakthrough for the promotion of international trade in services, and augurs well for the fastest growing and most dynamic sector in post-industrial societies.

\footnotetext{
${ }^{21} \mathrm{~W}$. Molle: The economics of European integration: Theory, practice, policy (Aldershot, Dartmouth Publishing
} Co. Ltd., 1994), Ch. 9. 
It is also a sector in which some developing countries have a comparative advantage, since, although they are short of capital, they are rich in human resources. The negotiations over the movement of natural persons, as opposed to legal persons (the socalled "Mode 4" of GATS), have, however, been slow and difficult, reflecting the worries of the more developed regions over the temporary admission of people who may subsequently stay permanently.

435. The negotiations currently centre on:

- Qualifications - accelerating mutual recognition of qualifications.

- Subcontracting schemes - to include lower-skilled service workers.

- Service personnel categories - achieving uniform definition and coverage of these categories and expanding them to include middle- and lower-skilled workers and professionals.

- Social security - separating short- from long-term social security contributions.

436. A global system for mutual recognition of qualifications, so that an architect, doctor, or nurse would have his or her credentials recognized in all countries, has yet to be developed. While some States allow employers to assess qualifications, many professions remain closed to those who have not passed national certification requirements. Some developing countries have dealt with this problem by incorporating into their curricula the requirements of the countries where graduates want to work, so that nurses in the Philippines, for example, are trained to pass nursing examinations in Canada, the United Kingdom or the United States. At the ILO Tripartite Regional Meeting on Employment in the Tourism Industry in Asia and the Pacific, held in Bangkok in 2003, one of the recommendations was for the ILO to develop certification for skilled workers in the industry who underwent specialized training.

437. The expansion of trade in services will, however, require agreement on important issues beyond recognition of qualifications and the simple matter of streamlining procedures for obtaining visas and work permits. Current commitments are largely premised on assumptions about the application of receiving-country labour laws and standards on the employment of the people providing services; but ensuring observance of those laws and standards in practice when the service involves brief periods of engagement poses formidable problems. This is an area where the tripartite parties have important interests and where social dialogue can be most useful.

\subsection{Preliminary conclusions: A complex policy challenge}

438. This chapter has argued that sound labour migration policy rests on identifying long-term interests, anchoring policies on respect for basic human rights, and having an effective mechanism for achieving broad social consensus. Governments will have to make clear the options or choices open to a country and what their long-term implications may be for the economy and society; there are difficult trade-offs, and some degree of conflict is unavoidable and even desirable in democratic societies. Not only will they have to argue the rational economic case for migration, they must also ensure that migration does not lead to exploitation of the migrants as well as marginalizing the weaker segments of the labour market, such as older workers or the less skilled, who also include earlier migrants. Migration must be, and be seen to be, a "win-win" proposition for all. 


\section{Box 6.8}

\section{Elements for a sound migration policy and administration}

Policy

- Incorporating principles contained in relevant international standards in national legislation and practice to ensure legal recognition and protection of fundamental human and labour rights of all migrant workers.

- Formulating migration policy with due regard to the overall labour market situation, criteria of decent work and promoting migration as an instrument of development and poverty reduction.

a Ensuring that measures taken in support of migration policy objectives are transparent and not inconsistent or in conflict with policies in other domains.

a Addressing the issues raised by irregular migration and trafficking, ensuring protection of basic human rights of concerned workers, identifying options, criteria and procedures for inter-country cooperation, and regularizing the status of workers in an irregular situation.

a Entering into bilateral or multilateral agreements to provide social security coverage and benefits to migrant workers and for a better management of migration, in conformity with relevant international standards and practices.

\section{Dialogue}

- Securing broad support for national policy through consultations and dialogue with the most directly affected parties, particularly the social partners as well as concerned civil society organizations and migrants themselves.

- Establishing formal structures for consulting workers' and employers' organizations on labour migration policy and administration.

a Engaging in regional and global consultative processes on international migration policy and cooperation.

\section{Administration}

a Establishing or strengthening capacities within ministries of labour for developing coherent and effective policy and administration on labour migration.

- Improving the information base for national migration policy through support to data collection efforts, research and publications.

- Reflecting the differences in conditions facing men and women migrants in measures to improve conditions and reduce specific vulnerabilities faced by female migrants.

a Adopting a comprehensive strategy against trafficking in migrants including protection, prevention and prosecution.

Social welfare

- Promoting access to health care for migrants, including promoting HIVIAIDS prevention.

- Addressing problems of discrimination and xenophobia against migrant workers, including through such means as national action programmes.

- Facilitating economic, social and cultural integration of regular migrant workers and family members into host societies.

439. While international relations often set the context for migration patterns, migration policy choices, by their very nature, reflect the values and priorities within and across societies. One of the major challenges in setting multilateral directions for migration policy is arriving at a consensus of values and priorities widely shared across source and destination countries which can support a framework for joint action.

440. Since migration directly affects the interests of workers and employers, achieving broad social consensus can be facilitated by establishing tripartite bodies to assist governments in formulating and implementing labour migration policy. The tasks of 
identifying requirements in the labour market and deciding how best to remedy gaps, of combating discrimination and promoting the integration of immigrants, and of informing the general public on the impact and consequences of labour migration, are best carried out with the participation of employers' and workers' organizations.

441. Managing migration is inherently a multilateral issue. Today's global scale of migration flows and the global reach of migration networks makes it all the more compelling for countries to look to partnerships overseas, through bilateral and multilateral agreements and treaties. At the same time the larger part of cross-border movements still occur within regional spaces, hence the value of regional migration agreements and processes for managing migration and protecting the workers. 


\section{Chapter 7}

\section{The way forward}

442. As the World Commission on the Social Dimension of Globalization has emphasized, cross-border movements of workers in search of employment and security are likely to grow in the coming decades, especially if globalization fails to generate jobs and economic opportunities where most people live. The differences - economic, demographic, social and political - that drive migration have widened over the past several decades and the trend is likely to continue unless fundamental changes in the global economy occur to spur growth, promote more equitable income distribution and reduce economic instability in regions of the world that are lagging behind.

443. Migration is an integral part of growth and development processes - more significant at some times and in some countries than others. Nevertheless, as with many aspects of development, there are both positive and negative impacts for the migrants themselves and for the countries of origin and destination. There is increasing recognition of the role that migration plays in meeting the demographic deficit and labour shortages in the more advanced economies, in global exchanges of technology and know-how, and in stimulating development through remittance flows and investments, especially from diaspora communities. The challenge is how to manage migration in such a way that the positive effects are maximized, making it beneficial for all.

444. Although migrants and their families have by and large benefited from migration, many still toil under abusive and exploitative employment conditions without effective access to legal protection. Migrant women in particular are often subjected to multiple forms of discrimination. There is an urgent need for efforts, at national and international levels, to ensure that the rights of migrants are respected in accordance with all applicable international standards.

445. If international and national standards are to have a tangible impact on the conditions of most migrants, migration processes must be better managed. Unregulated migration puts many migrants, especially women, in positions of vulnerability, and their status often effectively excludes them from social protection. The key to effective protection of migrants' rights is the effective management of migration.

446. A rights-based international regime for managing migration must rest on a framework of principles of good governance developed and implemented by the international community that will be acceptable to all and suitable as a basis for cooperative multilateral action. Existing international instruments defining the rights of migrant workers provide many of the necessary principles, but a sound framework would have to include principles on how to organize more orderly forms of migration that benefit all. 
447. To be effective, such a regime for managing migration must be accompanied by an appropriate follow-up mechanism to support actions by governments and their social partners in the implementation of these principles.

448. The general discussion at the International Labour Conference in 2004 might also specify how the ILO's various means of action can be used to further strengthen and expand assistance to governments and to employers' and workers' organizations in translating such principles into policy and practice at national levels in a number of areas including:

- creating alternatives for gainful employment in countries of origin;

- establishing orderly processes of labour migration;

- maximizing the contribution of migration to development;

- treatment of migrant workers in accordance with international standards;

- social protection of migrant workers and members of their families;

- combating xenophobia and discrimination;

- social and economic integration of immigrant workers;

- addressing the problems of migrants workers in an irregular status.

449. To this end, the general discussion could propose a well-defined plan of action which engages all the ILO's constituents - governments, and workers' and employers' organizations. Such a plan of action could also include the establishment by the ILO of an international forum on migration for work where all the relevant actors can be brought together on a regular, frequent and tripartite basis to consider appropriate responses to the issues raised by increasing migration.

\subsection{Issues for discussion for a plan of action}

450. This report proposes that the Conference consider adopting a plan of action which would engage the ILO and all its constituents in the development of a coherent multilateral framework for the governance of international migration. To this end the Conference may wish to discuss the following issues:

(a) The report highlights the fact that migration for employment is a growing global phenomenon. Do you agree? If so, what dimensions should be of particular concern for the ILO and its constituents?

(b) Under certain conditions the cross-border movement of workers can be mutually beneficial for countries of employment and origin, and to the migrants themselves. However, according to the report, substantial numbers of women and men migrants are working under exploitative conditions, deprived of their basic rights, and are often effectively excluded from social protection. What policies are needed to improve their condition? What should the ILO do in terms of international regulation to fill the gaps in protection and how should it develop and employ its various means of action in ways that enhance their complementarity and impact?

(c) The key to effective protection of migrants' rights is the effective, rights-based management of migration. To achieve this, one needs coherent, transparent and comprehensive national policies that enjoy broad public support, as well as greater cooperation between and among origin and host States. Apart from normative 
action, what can the ILO do to promote such policies and best practices in the overall management of labour migration?

(d) What other action should the ILO consider in order to facilitate a regular international exchange of information and views on international migration and to contribute to the development of good governance of international migration? 


\section{Annex I}

\section{Summary of replies to the International Labour Migration Survey, 2003}

\section{Introduction}

The analysis is based on the replies to the International Labour Migration Survey sent out in preparation for the general discussion based on an integrated approach at the International Labour Conference in 2004. The Survey aimed to obtain the latest information on ways in which migration and the treatment of migrant workers were being regulated through laws, policies and administrative measures; the role played by bilateral and multilateral agreements; and the way in which the tripartite partners take part in the process and the impact of the ILO instruments in this area. Replies to the Survey were received from 90 member States. ${ }^{1}$ The number of "Yes/No" replies reflects the answers given by the member States. Comments from the employers' and workers' organizations have been included where appropriate.

\section{Policies, laws and structures}

\subsection{National labour migration policies}

a Question 1A. Does your Government have a national policy on international labour migration?

Q Question 1B. Indicate if you have recently introduced or are contemplating introducing any changes in the near future to this national policy?

\footnotetext{
${ }^{1}$ Albania, Algeria, Argentina, Armenia, Australia, Austria, Bahrain, Belarus, Belgium, Bolivia, Brazil, Bulgaria, Burundi, Canada, Chile, China, Colombia, Costa Rica, Croatia, Cyprus, Czech Republic, Denmark, Ecuador, Egypt, El Salvador, Eritrea, Estonia, Ethiopia, Fiji, Finland, France, Germany, Greece, Guatemala, Honduras, Hungary, Iceland, Indonesia, Ireland, Japan, Kazakhstan, Kenya, Republic of Korea, Kuwait, Lebanon, Madagascar, Malawi, Malaysia, Malta, Mauritius, Mexico, Morocco, Myanmar, Netherlands, New Zealand, Nicaragua, Norway, Oman, Pakistan, Panama, Peru, Philippines, Poland, Portugal, Qatar, Romania, Rwanda, Senegal, Seychelles, Singapore, Slovakia, South Africa, Spain, Sri Lanka, Sudan, Suriname, Sweden, Switzerland, Syrian Arab Republic, Tajikistan, Thailand, Togo, Tunisia, Uganda, Ukraine, United Arab Emirates, United Kingdom, United States, Uruguay and Zimbabwe.
} 
Survey response

\section{National policy}

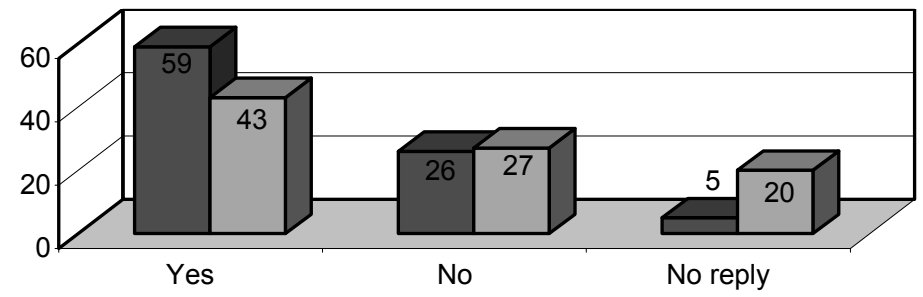

-National policy on labour migration

Introduced or contemplate introducing changes to national policy

\section{Remarks}

Approximately 70 per cent of member States who responded to the Survey declared that they have adopted a national policy on labour migration. Some trends in the objectives of the national migration labour policy could be determined. For example, countries such as Australia, Canada, Germany, New Zealand, United Kingdom or United States promote the immigration of highly skilled labour, sometimes based on a points test, in areas where there is a shortage of skilled nationals (either on a permanent or temporary basis), while still leaving the door open for the entry of a limited number of migrants who do not fall within these categories (e.g. for family members or asylum seekers). Japan has recently shifted its policy towards promoting the acceptance of migrant workers in certain technical and professional fields in order to invigorate and internationalize its society. The admission of highly skilled labour is also promoted in certain developing or transition countries in order to fill labour shortages (e.g. China, Czech Republic, Fiji, Republic of Korea, Mauritius, Poland, Thailand or Tunisia). In Austria, Belgium, Cyprus, France, Lebanon, Malaysia, Netherlands, Norway, Sweden and Ukraine, the principal focus is to ensure that nationals and regular migrants are fully employed. Recruitment of migrant workers is restricted to certain situations such as the absence of national workers with the appropriate skills to fill the position. Combating irregular migration, human trafficking and smuggling was an objective for a number of both receiving and sending countries (e.g. Albania, Czech Republic, Germany, Indonesia, Netherlands, Portugal, South Africa, Switzerland, Tajikistan, Thailand, United Kingdom). The integration of migrant workers is focused on in Austria, Czech Republic, Portugal, Tajikistan, South Africa and Switzerland and the regularization of irregular migrant workers is focused on in Argentina and Chile. Finally, policies in some countries (e.g. Egypt, Ethiopia, Mexico, Morocco, Philippines, Poland, Portugal, Tajikistan and Tunisia) are aimed at assisting nationals working abroad, ensuring that they receive equal treatment when in the receiving country, and encouraging the return of migrant workers.

\subsection{Tripartite consultation}

- Question 2. Are representative employers' or workers' organizations taking part in the formulation of labour migration policies, laws and regulations?

口 Question 3. Do any representative employers' or workers' organizations carry out specific activities or services targeted at migrant workers? 
Survey response

\section{Participation by employers' and workers' organizations}

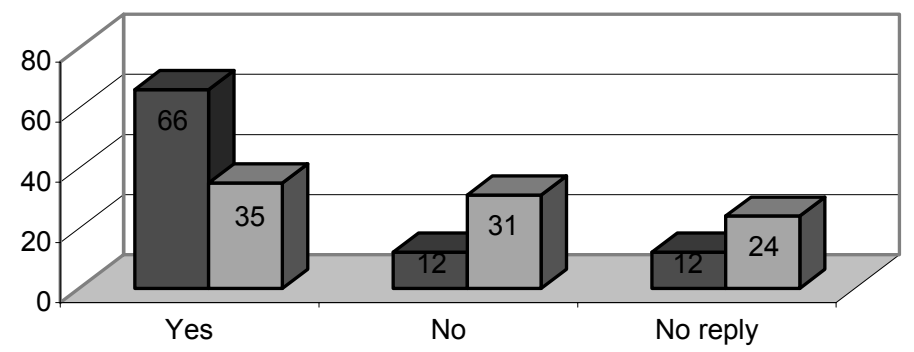

Participation in policy and law

$\square$ Specific activities targeted at migrant workers

\section{Remarks}

The majority of respondents replied that employers' and workers' organizations took part in the formulation of labour migration policies, laws and regulations. Of these, almost half specified that consultations were undertaken in the framework of formally established tripartite bodies. However, no consultations were undertaken or no response was provided to this question in approximately 25 per cent of cases. Specific activities carried out by employers' and workers' organizations included advisory and integration services as well as training programmes specifically designed for migrant workers in the country. Some organizations also provided advisory and placement services for nationals going abroad.

\subsection{Laws and regulations on migration for employment}

a Question 4A. Do you have laws and regulations on migration for employment in your country (immigration)?

a Question 4B. Do you have laws and regulations on migration for employment from your country (emigration)?

Survey response

\section{Laws and regulations}

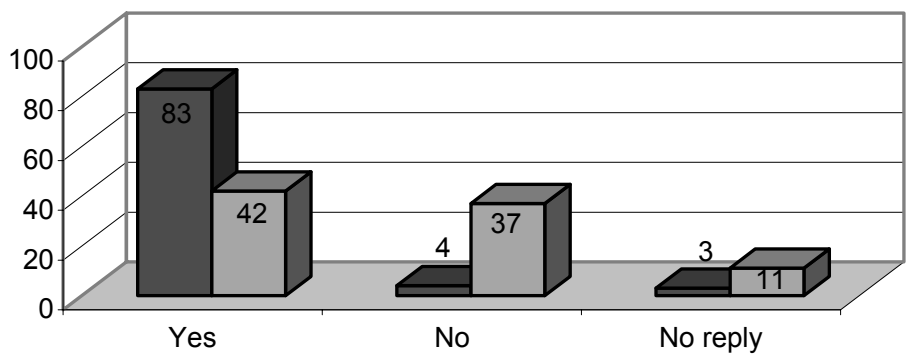

口Immigration laws

口Emigration laws

a Question 39. With respect to migration for employment from your country, do you have specific provisions regulating the following? 
Table 1. Specific legal provisions for emigration

\begin{tabular}{llrrr}
\hline Q.39 & & Yes & No & No reply \\
\hline A & Contracts and contractual conditions of migrant workers & 35 & 31 & 24 \\
B & Mandatory recruitment through public employment offices & 15 & 50 & 25 \\
C & Direct recruitment by employers & 28 & 37 & 25 \\
D & Recruitment through private recruitment agencies & 32 & 35 & 23 \\
E & Licensing of private recruitment agencies & 32 & 35 & 23 \\
F & Prosecution against recruitment malpractices & 36 & 25 & 29 \\
\hline
\end{tabular}

a Question 5. Are questions related to labour migration provided for expressly or through practice, in any of the following laws or agreements in your country?

Table 2. Laws and agreements regulating labour migration expressly or through practice

\begin{tabular}{llrrr}
\hline Q.5 & & Yes & No & No reply \\
\hline A & Constitution & 44 & 28 & 18 \\
B & Labour law & 68 & 12 & 10 \\
C & Employment law & 63 & 12 & 15 \\
D & Human rights law & 43 & 20 & 27 \\
E & Social security law & 60 & 13 & 17 \\
F & Equality or non-discrimination law & 46 & 17 & 27 \\
G & Immigration law & 68 & 8 & 14 \\
H & Anti-trafficking law & 38 & 25 & 27 \\
I & Anti-smuggling law & 37 & 25 & 28 \\
J & Criminal law & 50 & 18 & 22 \\
K & Collective agreements & 26 & 36 & 28 \\
\hline
\end{tabular}

Remarks

The information provided in the Survey indicated that issues related to migration were dealt with in a wide array of laws and regulations, in particular labour and employment laws, social security laws and immigration laws.

\subsection{Competent authorities}

a Question 8. Please indicate the name of the competent national authority(ies) engaged in the implementation of matters relating to:
A. Immigration policy
B. Work permits
C. Permits to reside/stay 


\section{Survey response}

\section{Competent authorities/ministries responsible for migration}

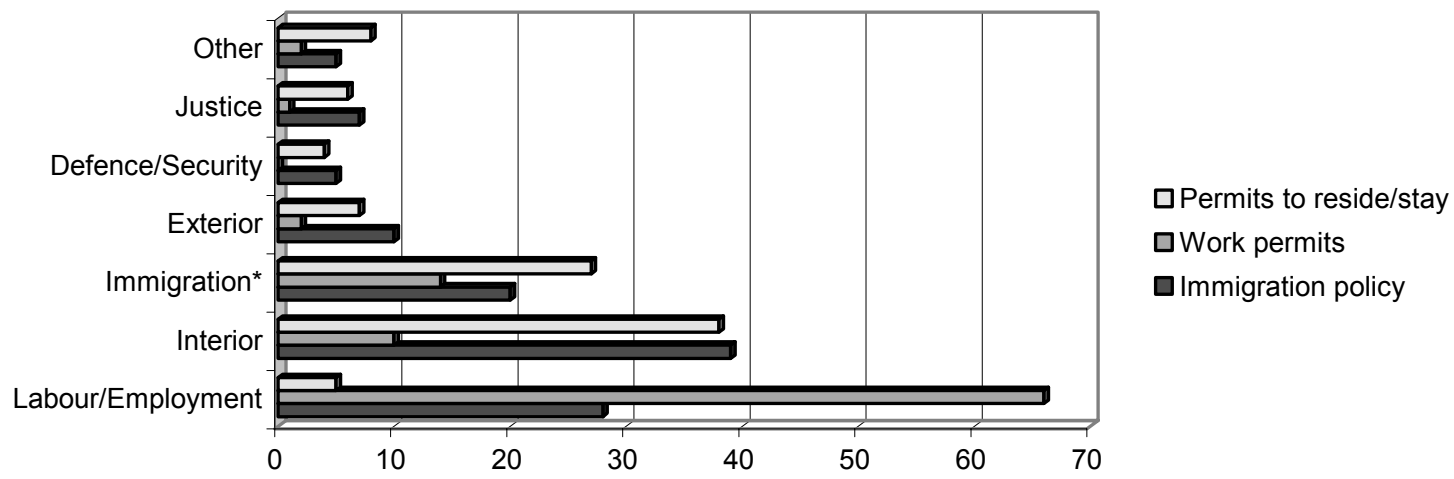

* The replies either indicated that this was a ministry in itself or did not indicate the ministry responsible for the immigration service/department.

a Question 38. Do you have a competent authority(ies) specifically placed in charge of labour emigration? If yes, please specify if it exercises the following functions and powers:

\section{Table 3. Competent emigration authorities}

\begin{tabular}{llrrr}
\hline Q.38 & Yes & No & No reply \\
\hline 38 & $\begin{array}{l}\text { Competent authority(ies) specifically placed in charge of labour } \\
\text { emigration }\end{array}$ & 46 & 28 & 16
\end{tabular}

Functions and powers:

\begin{tabular}{|c|c|c|c|c|}
\hline A & $\begin{array}{l}\text { Formulate policies regarding the employment of nationals in foreign } \\
\text { countries }\end{array}$ & 38 & 8 & 44 \\
\hline $\mathrm{B}$ & Enter into agreements with foreign employers & 30 & 17 & 43 \\
\hline C & Authorize or license natural or legal persons to engage in recruitment & 34 & 14 & 42 \\
\hline $\mathrm{D}$ & Recruit nationals for employment abroad & 29 & 15 & 46 \\
\hline$E$ & Set minimum standards for employment contracts & 37 & 8 & 45 \\
\hline $\mathrm{F}$ & Approve work contracts whose terms meet standards and regulations & 34 & 10 & 46 \\
\hline G & Prosecute violators of recruitment regulations & 36 & 8 & 46 \\
\hline $\mathrm{H}$ & Collect fees & 15 & 25 & 50 \\
\hline I & $\begin{array}{l}\text { Arbitrate disputes between migrant workers and their foreign employers } \\
\text { or agents }\end{array}$ & 25 & 17 & 48 \\
\hline $\mathrm{J}$ & Campaign against trafficking and smuggling & 36 & 7 & 47 \\
\hline K & $\begin{array}{l}\text { Provide pre-departure information on rights, living and working } \\
\text { conditions for migrant workers in destination countries }\end{array}$ & 38 & 5 & 47 \\
\hline$L$ & $\begin{array}{l}\text { Collect information on malpractices and violations of rights of migrant } \\
\text { workers in host countries }\end{array}$ & 34 & 9 & 47 \\
\hline M & Provide assistance to migrant workers in host countries and upon return & 35 & 11 & 4 \\
\hline
\end{tabular}




\subsection{Administrative and legal assistance}

Q Question 6. In order to assist migrant workers in asserting their rights, have you done any of the following?

Survey response

Table 4. Administrative and legal assistance

\begin{tabular}{llcrr}
\hline Q.6 & & Yes & No & No reply \\
\hline A & Set up a programme or service for such a purpose & 53 & 28 & 9 \\
B & $\begin{array}{l}\text { Developed and disseminated information on national labour } \\
\text { standards and institutions }\end{array}$ & 62 & 21 & 7 \\
C & $\begin{array}{l}\text { Provided translations of relevant information in different } \\
\text { languages }\end{array}$ & 51 & 31 & 8 \\
\hline
\end{tabular}

\section{Remarks}

The majority of countries indicated that they have set up programmes or services for migrant workers and/or provide information on the rights and obligations of migrant workers under national law and regulations. Just over half the replies indicated that laws and regulations were translated into the languages most often used by migrants in their country. Other forms of assistance included governmental advisory services, settlement grants for migrant workers as well as information dissemination through various media.

\subsection{Bilateral agreements}

- Question 7. Have you entered into any bilateral or multilateral labour or other agreements with other countries covering the recruitment, admission, employment, and social protection of migrant workers?

\section{Survey response}

\section{Bilateral agreements}

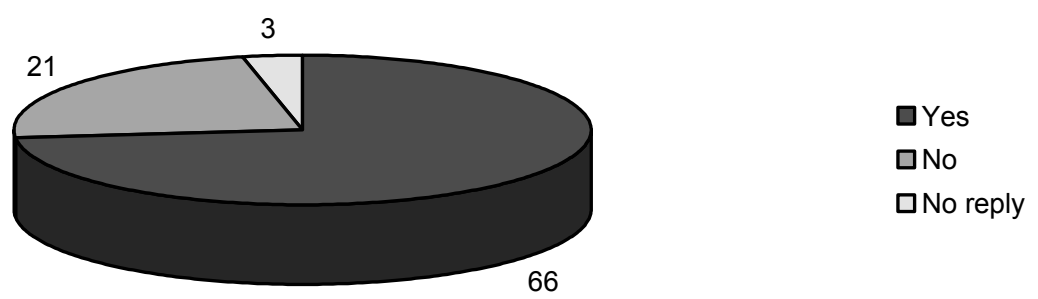

\section{Remarks}

Most countries had signed bilateral agreements, mainly on labour migration and social security. The Survey confirms the trend of a revival of bilateral agreements as many of the agreements were signed in the 1990s and early 2000s. A large number of agreements involve Central or Eastern European countries or ex-USSR countries, some focusing on recruitment in EU countries. Finally, a few countries have begun to sign Working Holiday Maker (WHM) agreements that allow young people to undertake incidental employment while travelling in the receiving countries, under reciprocal arrangements. It should also be noted that 33 countries, including 23 that had not ratified 
Convention No. 97, replied that they had used, or intended to use, Recommendation No. 86 , which provides a model agreement on migration for employment.

\subsection{Admission}

a Question 9. Are quotas or limits set on the total number of migrant workers that may be admitted during a particular period (for example, a calendar year)?

a Question 10. Are quotas or limits set on the total number of migrant workers who may be admitted during a particular period for:
A. Selected countries of origin?
B. Certain branches of economic activity?
C. Specific occupations?
D. Migrant workers with particular levels of skills?

Survey response

\section{Quotas and limits}

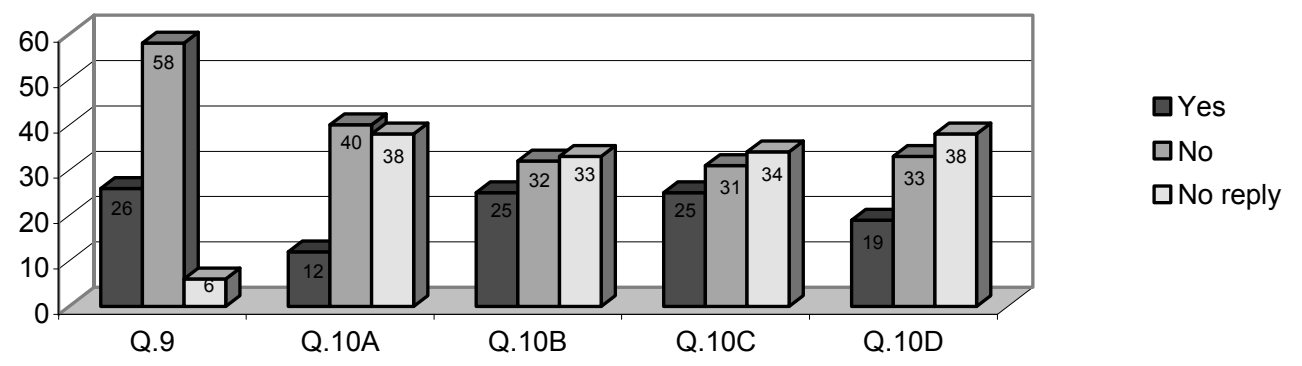

- Question 12. Do you allow for preferential treatment in terms of admission for:

A. Migrant workers from specific countries?

B. Migrant workers from countries with whom you have entered into bilateral or multilateral or other agreements concerning migrant workers?

C. Migrant workers from countries with whom you have formed an economic union or political association?

D. Migrant workers that satisfy other criteria such as specific ethnic origin or ancestry?

Survey response

\section{Preferential treatment}

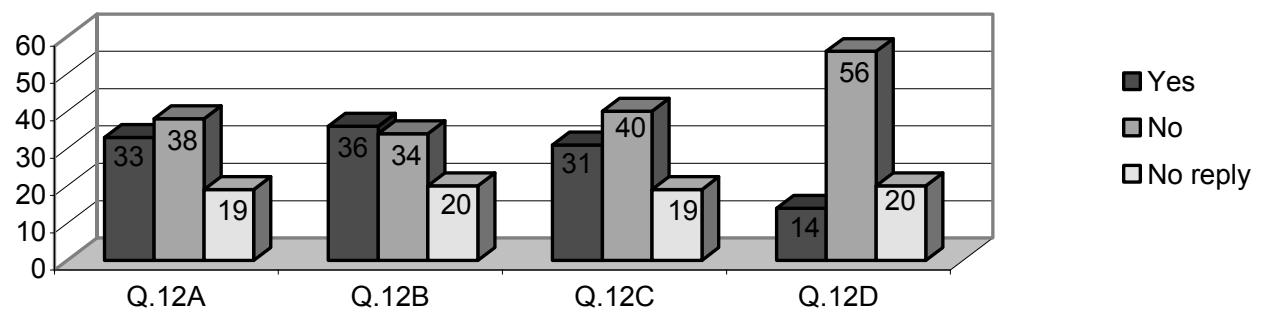




\section{Remarks}

One-third of countries replied that they had specific quotas for migrant workers who may be admitted for certain reasons, the most common being for employment in certain branches of activity or employment or, to a lesser extent, for workers with particular levels of skills. The majority of respondents replied that they allowed for preferential treatment; for the most part this is accorded to specific countries, either through bilateral agreements or by virtue of existing political or economic ties.

a Question 13. Is admission excluded for migrant workers originating from any specific countries?

a Question 14. Is there a requirement that migrant workers test negatively for HIVIAIDS in order to gain admission into your country?

Survey response

\section{Grounds for exclusion}

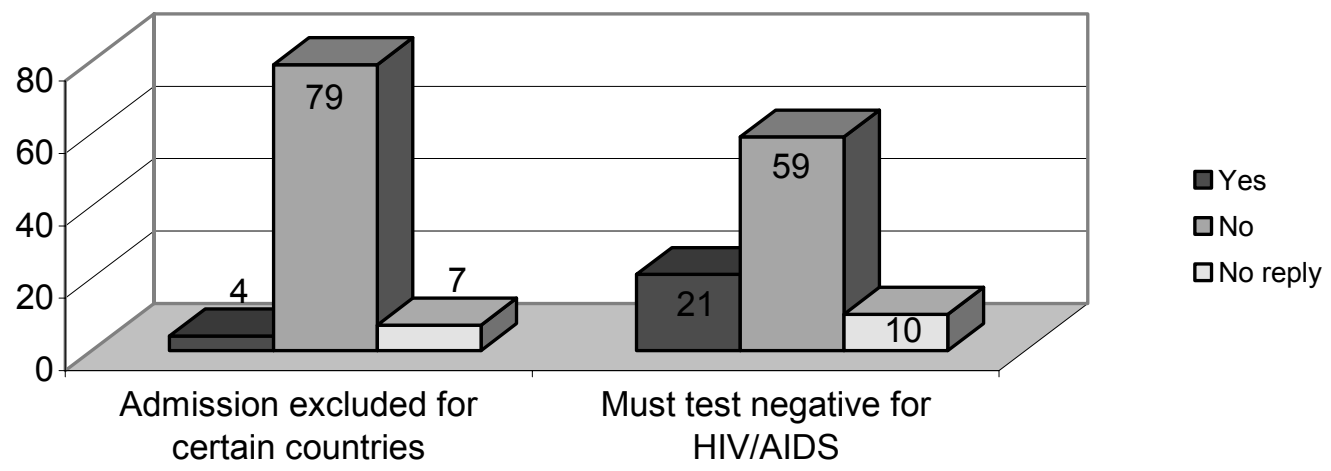

\section{Remarks}

There are very few cases where countries exclude migrant workers from specific countries. However, the exclusion of the admission of nationals from certain countries is not always negative. For example, one country excludes the employment of nurses from certain countries where there is a nursing shortage.

a Question 15. Does your country provide for different admission categories for the purpose of employment?

\section{Survey response}

\section{Admission categories}

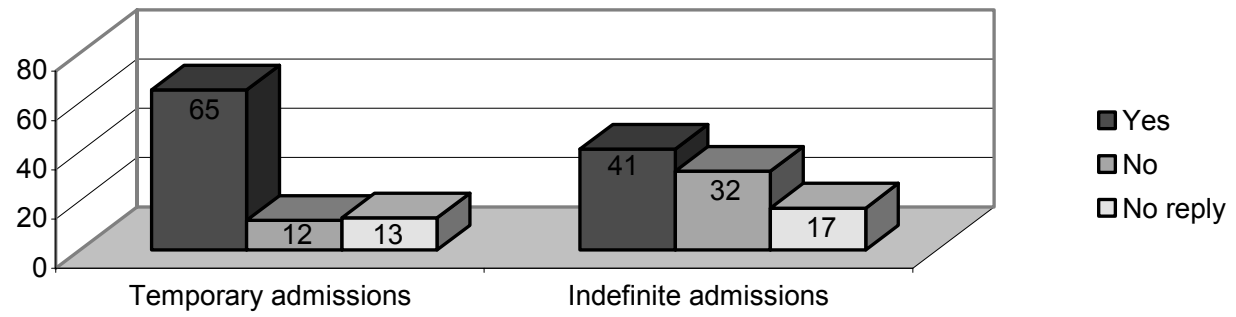




\section{Remarks}

Sixty-five countries provided admission for temporary migrant workers, less than one-third of which require a deposit to ensure that temporary migrant workers will leave the country (Q.16.I).

\subsection{Recruitment}

Question 16. Please indicate the conditions that an employer in your country has to meet in order to be allowed to employ migrant workers:
A. Must demonstrate a lack of qualified applicants .. weeks after announcement of job offer.
B. Must offer to migrant workers a wage no less than that offered to nationals.
C. Must offer migrant workers a premium over wage offered to nationals.
D. Must be willing to pay a migrant worker's levy or tax.
E. Must be in a selected or priority industry/branch of economic activity.
F. Must qualify as an export industry/branch of economic activity.
G. Must qualify as a small or medium-sized enterprise.
$\mathrm{H}$. Must be in a priority geographic area or region.
I. Must put up a deposit to guarantee return of migrant worker.

Survey response

\section{Economic needs tests}

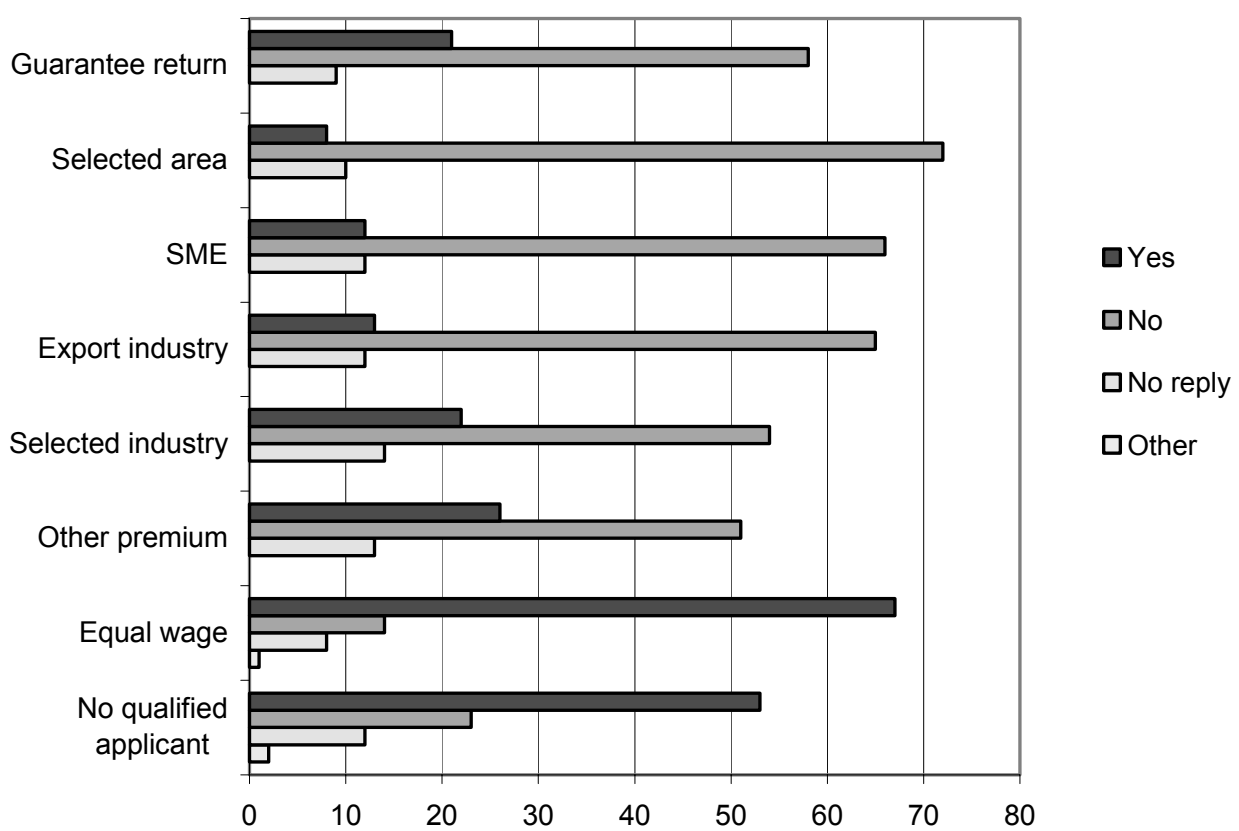

Remarks

The most common criteria an employer must fulfil before hiring a migrant worker are: proof that there is a lack of qualified national applicants; paying migrant workers a premium or a wage no less than that offered to nationals, or employment in selected industries/branches of economic activity. 
Q Question 17. Can private recruitment agencies be granted authorization to bring in migrant workers?

- Question 18. Are private recruitment agencies allowed to charge migrant workers recruitment fees to cover services?

a Question 20. In addition to legal sanctions and penalties, has your Government instituted any other special measures - for example collaborations with origin countries - to combat recruitment malpractices?

- Question 40. Are private recruitment agencies allowed to charge migrant workers placement fees?

Survey response

\section{Private recruitment agencies}

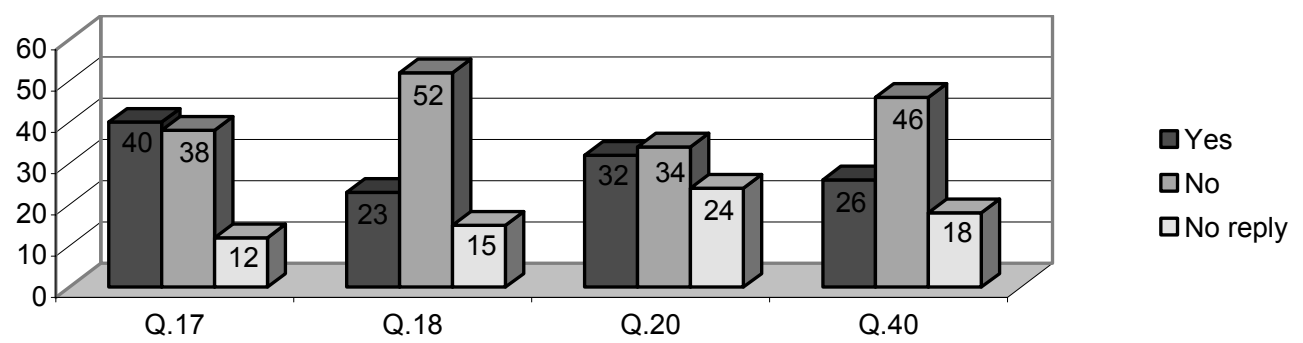

Remarks

Just under half the respondents replied that private recruitment agencies could be granted authorization to bring in migrant workers. In the majority of these cases, authorization was granted on the condition that they were bringing in the worker on behalf of an employer. Twenty-three respondents replied that private recruitment agencies were allowed to charge migrant workers recruitment fees to cover services and 26 replied that fees could be charged for the foreign employment of nationals. In some cases, fees could be charged under certain conditions, such as for specific occupations (e.g. performers, models, etc.). In certain countries it was the employer, not the migrant worker, who paid the recruitment fees. The amount to be paid varied from country to country but was usually either a fixed fee or a percentage of the worker's salary. Examples ranged from 10 per cent of the first month's salary to 14 per cent of the annual salary. In some countries, this area was not regulated and was left up to the parties involved to determine. Thirty-one respondents replied that they had instituted special practices to combat recruitment malpractices. Initiatives included intergovernmental collaboration, awareness-raising campaigns for potential victims of trafficking and the provision of advisory services to employers and migrant workers, as well as regional and international conferences.

\subsection{Rights and benefits}

Q Question 21. Please indicate whether nationals as well as migrant workers (regular and irregular) in your country are entitled to the rights and benefits listed. 
Survey response

\section{Table 5. Categories of workers that receive the following rights and benefits}

\begin{tabular}{|c|c|c|c|c|c|c|c|}
\hline Rights and benefits & 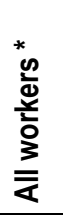 & 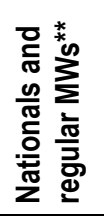 & 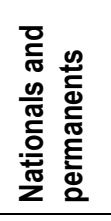 & 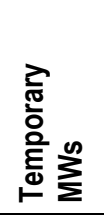 & 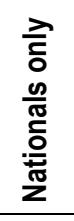 & 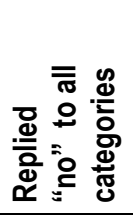 & $\begin{array}{l}\text { 흘 } \\
\text { 을 }\end{array}$ \\
\hline Form or join workers' organizations & 27 & 26 & 9 & - & 14 & 0 & 14 \\
\hline Bargain collectively & 25 & 31 & 8 & - & 12 & 1 & 13 \\
\hline Protection against forced labour & 45 & 23 & 4 & - & 5 & 1 & 12 \\
\hline Protection against discrimination at work & 42 & 28 & 3 & - & 5 & 1 & 11 \\
\hline Minimum age of employment & 41 & 28 & 4 & 1 & 5 & 1 & 10 \\
\hline $\begin{array}{l}\text { Equal treatment with national workers in respect } \\
\text { of wages }\end{array}$ & 35 & 32 & 4 & - & 4 & 1 & 14 \\
\hline $\begin{array}{l}\text { Equal treatment with national workers in respect } \\
\text { of minimum wages }\end{array}$ & 37 & 31 & 2 & 2 & 4 & 0 & 14 \\
\hline Right to join a social protection scheme & 24 & 35 & 7 & - & 9 & 1 & 14 \\
\hline Protection against sexual harassment & 46 & 20 & 5 & 1 & 4 & 0 & 14 \\
\hline Protection against ethnic and racial harassment & 44 & 22 & 4 & - & 5 & 1 & 14 \\
\hline Access to training & 18 & 40 & 10 & - & 7 & 1 & 14 \\
\hline Access to free public medical/health services & 22 & 24 & 8 & 5 & 11 & 1 & 19 \\
\hline Free housing (e.g. for agricultural workers) & 9 & 15 & 2 & 3 & 9 & 20 & 32 \\
\hline Accompanied by family members & 14 & 41 & 9 & 2 & 6 & 1 & 17 \\
\hline Public schooling for their children & 28 & 26 & 11 & - & 11 & 1 & 13 \\
\hline Vote in local/national elections & 2 & 4 & 15 & - & 49 & 0 & 20 \\
\hline $\begin{array}{l}\text { Access to legal proceedings in a language } \\
\text { they understand }\end{array}$ & 42 & 19 & 3 & - & 7 & 1 & 18 \\
\hline $\begin{array}{l}\text { Adequate prevention of occupational accidents } \\
\text { or diseases }\end{array}$ & 42 & 27 & 4 & - & 4 & 1 & 12 \\
\hline $\begin{array}{l}\text { * Includes irregular migrant workers. } \\
\text { ** Permanent and temporary migrant workers. }\end{array}$ & & & & & & & \\
\hline
\end{tabular}

Remarks

The right to form or join a workers' organization and to bargain collectively was available to "all workers" less frequently than the other fundamental rights, and a relatively high proportion of countries replied that the right was available to "nationals only". Irregular migrant workers seem to enjoy relatively better protection concerning the other fundamental rights (protection against forced labour, discrimination at work, minimum age and equal treatment with respect to wages) as well as against sexual, ethnic and racial harassment. In addition, with regard to the right to join a social protection scheme and to access free public medical/health services, the number of replies indicates that "nationals and regular migrant workers" are more often covered than "all workers". This could reflect the lack of protection of irregular migrant workers in these fields. Concerning the rights reserved for "nationals only", the figures are quite 
"low" for all the categories referred to in table 5, except for the right to vote in local and national elections.

\subsection{Social protection}

Q Question 22. Do you have any of the following systems of social protection in your country?
A. Social insurance (SI), i.e. contributory schemes.
B. Provident funds or mandatory savings schemes (PF).
C. Social assistance (SA), financed from taxes, for those with low income or means.
D. Universal benefits (UB) financed from taxes and usually residency based.
E. Schemes financed by employers only (ES).

Q Question 23. Are migrant workers entitled to:
A. Maintain their acquired rights with respect to long-term benefits (old-age benefit, invalidity, survivors' benefit)? (a) only if they stay in the country; or (b) regardless if they stay in your country or not.
B. Accumulate rights in situations where work is carried out in different countries over a period of time?

Survey response

\section{Systems of social protection}

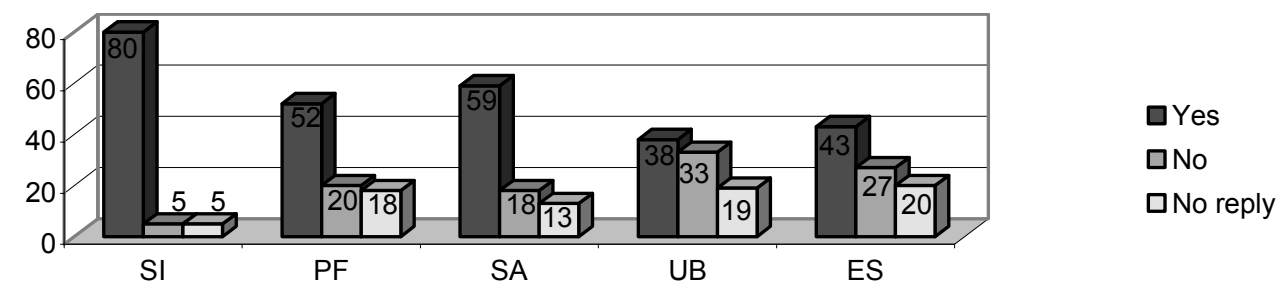

\section{Scope and coverage of national social security benefits (Q.23)}

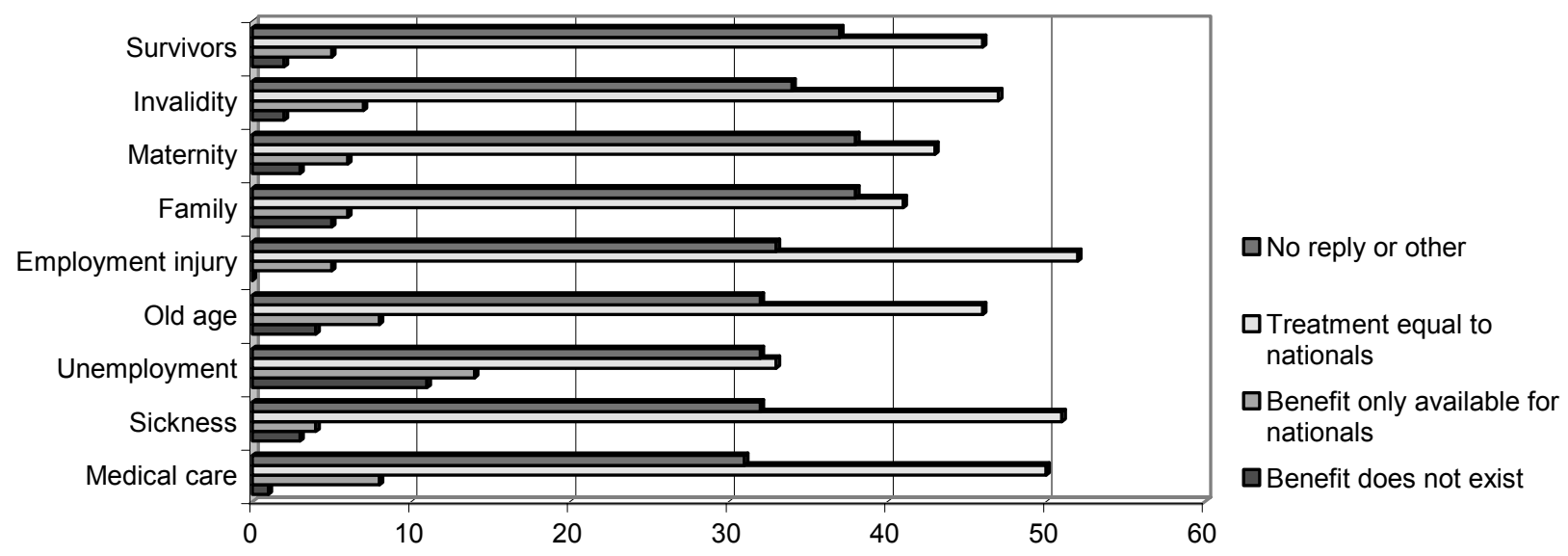




\section{Payment of benefits to beneficiaries residing abroad (Q.23)}

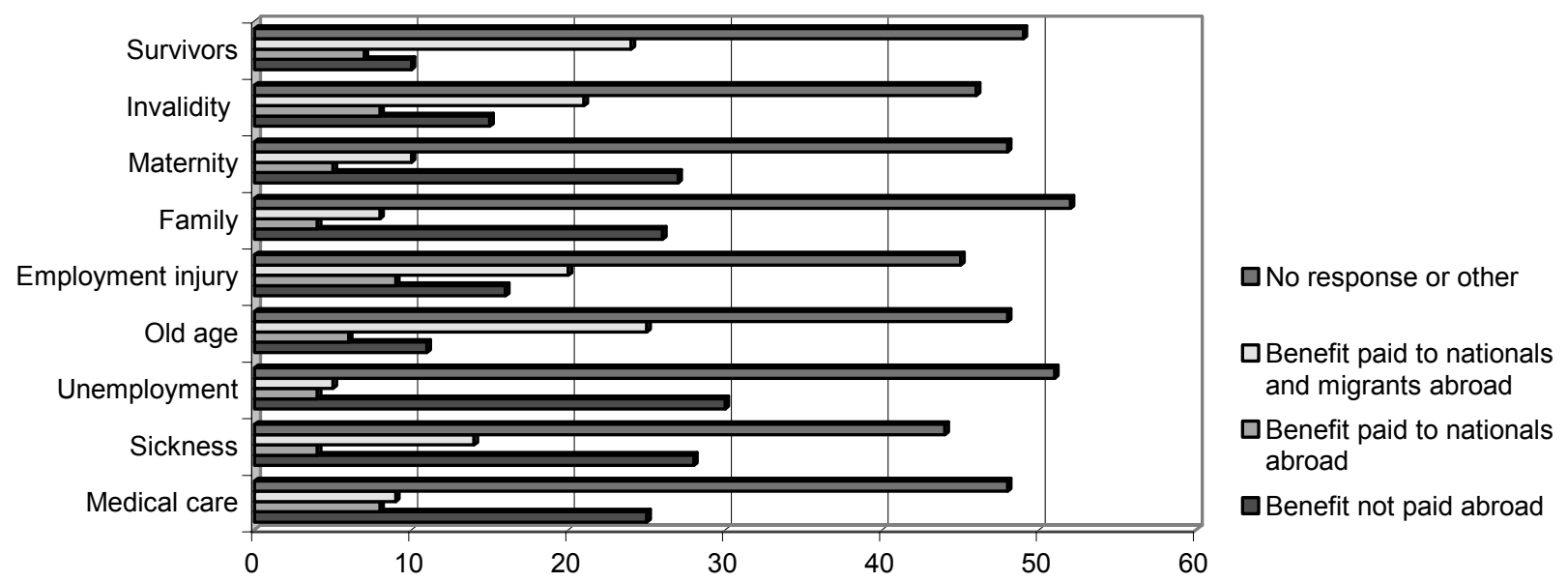

\subsection{Occupational mobility}

a Question 24. Are there any restrictions regarding the occupational mobility of migrant workers (i.e. on the right of migrant workers to accept offers of employment by a person or entities other than those who arrange the migrant workers' admission into the country?
A. Change of employer not allowed under any circumstance
B. Change of employer allowed subject to prior approval by competent authority
C. Change of employer allowed at any time if in the same branch of economic activity
D. Change of employer allowed only after certain years of legal employment

\section{Survey response}

\section{Occupational mobility}

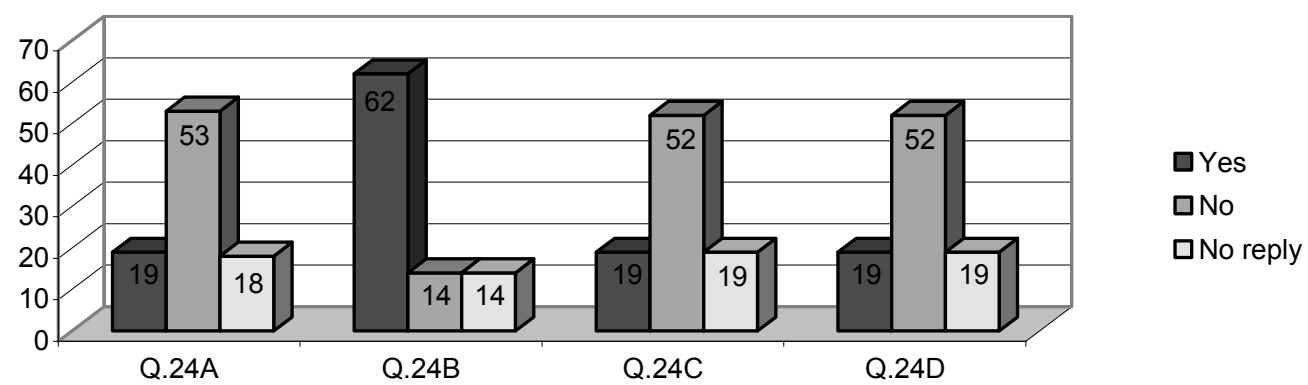

\section{Remarks}

Even if occupational mobility is completely restricted in more than 20 per cent of responding countries for temporary migrant workers, occupational mobility is allowed, subject to prior approval by the competent authority, in almost 70 per cent of countries. 


\subsection{Termination of employment}

- Question 25. Are migrant workers who lose their employment through no fault of their own, prior to the termination of their contract:
A. Allowed to stay and seek other employment?
B. Assisted in finding other employment?
C. Required immediately to return to country of origin?
D. Given separation pay and sent home?

Survey response

\section{Loss of employment}

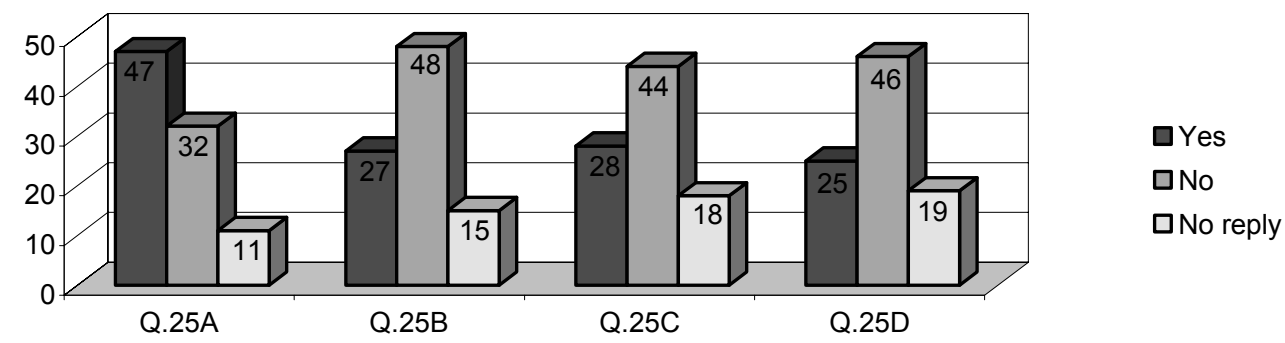

a Question 26. Upon regular termination of their contract, are temporary or guest migrant workers allowed to remain in your country to seek other employment?

Survey response

\section{Migrant workers allowed to remain in country to seek other} employment upon regular termination
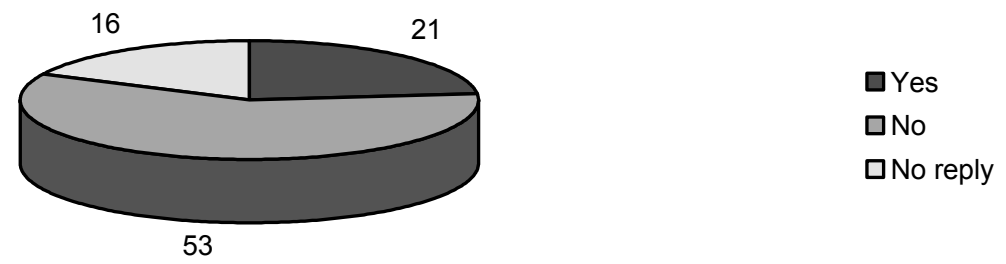

\section{Remarks}

Just over half the countries that responded to the Survey replied that they allowed migrant workers to stay and seek other employment if they lost their employment through no fault of their own. However, 23 per cent of countries declared that they allowed temporary migrant workers to stay and seek employment after the regular termination of their contract.

a Question 27. Are the following considered valid grounds for termination of employment of migrant workers?
A. Injury or illness.
B. Testing positively for HIVIAIDS. 
Survey response

\section{Valid grounds for termination of employment}

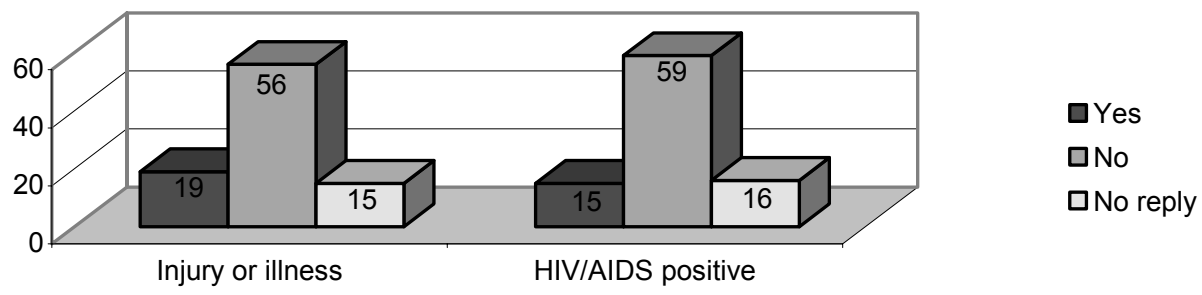

\subsection{Monitoring and inspection}

a Question 28. Does your Government monitor the conditions of employment of migrant workers? If yes, through which means [table 6].

- Question 29A. Does your regular labour inspection system include special procedures for monitoring migrant workers and their working conditions?

- Question 29B. Please indicate whether these procedures are intended to determine if the situation of migrant workers is in compliance with any or all of the following national labour standards [table 7].

- Question 30. Are special inspections conducted in case of complaints by migrant workers, such as by victims of trafficking or by foreign domestic helpers?

\section{Survey response}

\section{Monitoring the employment conditions of migrant workers}

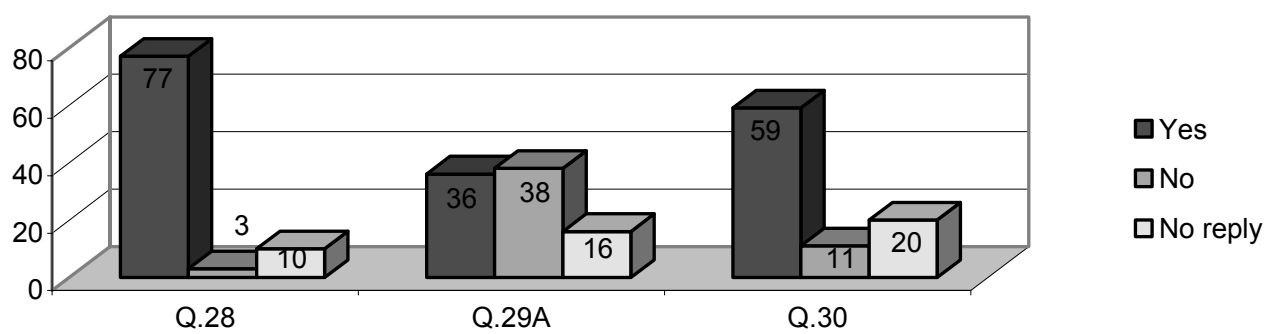

\section{Table 6. Means through which member States monitor the conditions of employment of migrant workers}

\begin{tabular}{llrrr}
\hline Q.28 & & Yes & No & No reply \\
\hline A & General labour inspection & 77 & 2 & 11 \\
B & Reports of competent authority in charge of issues regarding migrant workers & 57 & 9 & 24 \\
C & Complaints received from the workers themselves & 69 & 6 & 15 \\
D & Reports from local administrative bodies & 56 & 13 & 21 \\
E & Reports from trade unions or other workers' organizations & 59 & 13 & 18 \\
F & Reports from employers or employers' organizations & 57 & 13 & 20 \\
G & News media & 55 & 15 & 20 \\
H & Reports from NGOs & 51 & 16 & 23 \\
\hline
\end{tabular}




\section{Table 7. Special procedures for monitoring migrant workers are intended to determine situation of migrant workers with respect to:}

\begin{tabular}{llrrr}
\hline Q.29B & Yes & No & No reply \\
\hline A & Non-discrimination & 58 & 5 & 27 \\
B & Minimum age for employment & 60 & 4 & 26 \\
C & Prohibitions against physical/sexual abuse/harassment & 56 & 7 & 27 \\
D & Remuneration according to minimum wage & 62 & 3 & 25 \\
E & Payment of salaries according to contract & 58 & 4 & 28 \\
F & Prohibition against wage reductions in excess of that allowed in law & 57 & 5 & 28 \\
G & Entitlements to rest periods/days & 61 & 2 & 27 \\
H & Entitlements to adequate housing & 42 & 18 & 30 \\
I & Entitlements to safe and healthy working conditions & 62 & 2 & 26 \\
J & Discrimination between men and women migrant workers & 55 & 7 & 28 \\
\hline
\end{tabular}

\section{Remarks}

While the majority of respondents indicated that they monitored the working conditions of migrant workers through general labour inspections, only 40 per cent indicated that they had a special system for monitoring migrant workers. Where specific systems existed, these included the monitoring of migrant workers by specialist units or regular labour inspectors. Other methods included administrative verification of work conditions by the competent authority. In general, where special labour inspections were carried out, they were aimed at ensuring that migrant workers have the same working conditions as national workers as well as monitoring the validity of work permits. Of the 60 per cent of respondents that replied that there were no specific procedures, a number said that this was because they did not make the distinction between migrant and national workers. However, in over 66 per cent of member States that replied, special inspections were carried out in response to complaints from migrant workers.

\subsection{Regularization}

a Question 33. Is there an established procedure through which irregular migrant workers can regularize their status?

- Question 34. On what grounds have irregular migrant workers been considered to qualify for regularization?
A. Being sufficiently employed.
B. Length of stay in the country.
C. No criminal record.
D. Ability to understand and speak language of the country. 
Survey response

\section{Established procedure to regularize status of irregular migrant workers}
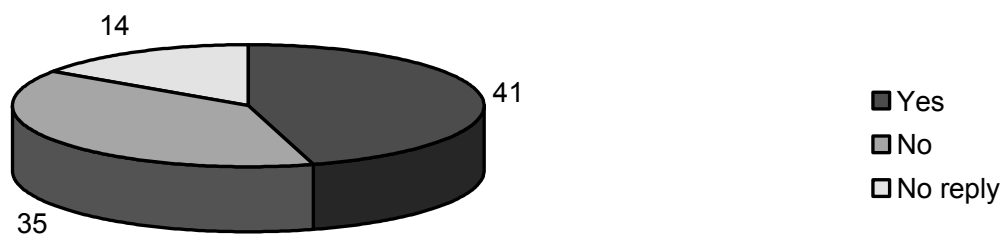

\section{Grounds upon which irregular migrant workers are considered to qualify for regularization}

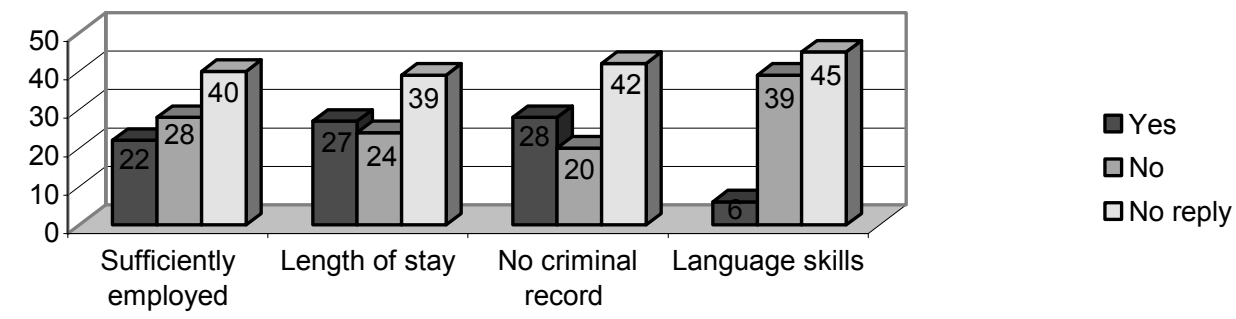

Remarks

Employment, residence and not having a criminal record seem to be the most frequent grounds needed to qualify for regularization. Many countries use a combination of these requirements, along with other criteria such as the existence of family ties with nationals or regular residents, the degree of integration of the migrant worker, or the presence of children in the family group asking to be regularized.

\subsection{Expulsion}

Question 35. Do you have an established procedure for hearing appeals against expulsion?

- Question 36. Does your Government allow victims of trafficking to remain in the country while law enforcement agencies pursue the prosecution and conviction of their traffickers?

Survey response

\section{Expulsion}

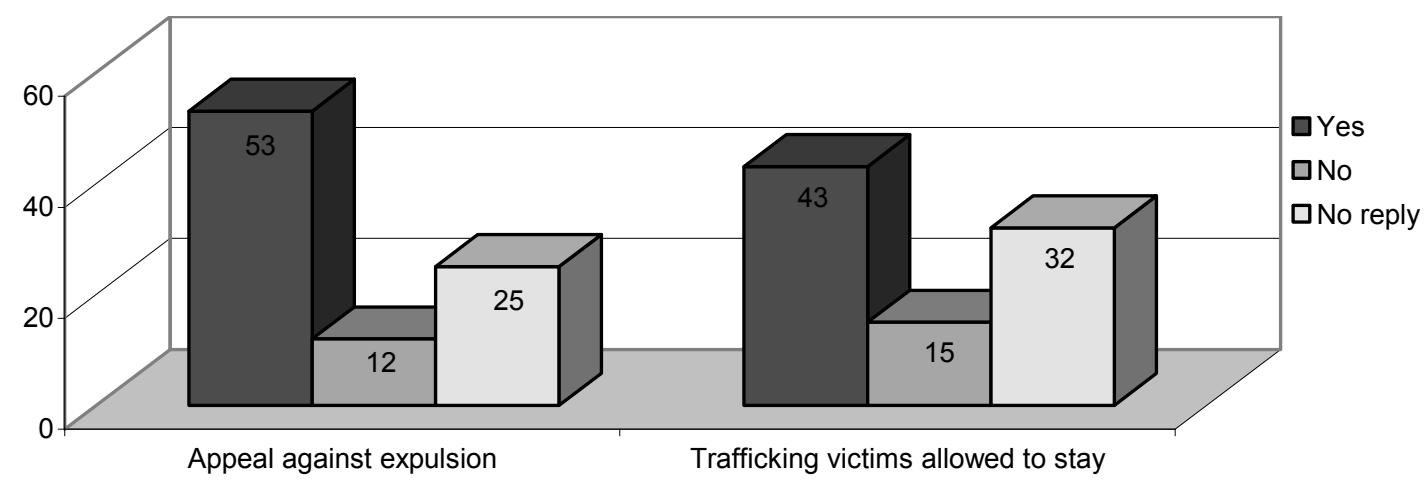




\section{ILO action}

\subsection{International labour standards}

Q Question 41. If you have not already done so, have you initiated or do you intend to initiate ratification procedures for the following ILO Conventions on migrant workers:

(a) Migration for Employment Convention (Revised), 1949 (No. 97), and/or (b) Migrant Workers (Supplementary Provisions) Convention, 1975 (No. 143)?

If no, please specify whether any specific Article or Articles in either one of these instruments represent an obstacle to ratification.

Survey response

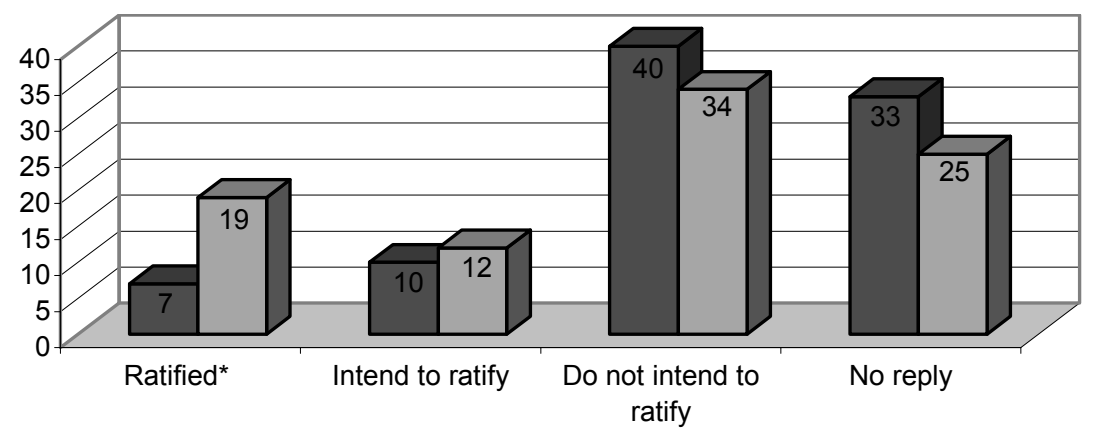

口Convention No. 143

口Convention No. 97

* Numbers refer only to those countries that replied to the Survey.

Articles of Convention No. 97 that pose obstacles to ratification

- Article 2 - free service to assist migrants for employment (Estonia, Sri Lanka).

- Article 6 - equal treatment to nationals (Mexico, Slovakia and United Arab Emirates).

- Article 7 - cooperation between member States and free public employment service (Estonia).

- Article 8 - migrant worker allowed to remain in country after termination of employment contract due to illness or injury (Slovakia).

- Annexes I, II and III (Madagascar, Slovakia).

Articles of Convention No. 143 that pose obstacles

to ratification

- Article 2 - determine conditions of irregular migrant workers (Mexico).

- Article 3 - suppression of clandestine movement of migrants and organizers or illicit or clandestine movements (Mexico).

- Article 6 - detection of and penalties against illegal employment (Mexico).

- Article 8 - effects of loss of employment on the migratory situation and equality of treatment concerning security of employment (Mauritius and Netherlands).

- Article 9 - equal treatment of migrant worker with respect to rights arising out of past employment as regards remuneration, social security and other benefits (Mexico).

- Article 10 - equality of opportunity and treatment (Estonia, Germany, Mauritius and Mexico). 
- Article 12 - cooperation with employers' and workers' organizations, enactment of legislation and encouragement of educational programmes (Germany, Mexico and Slovakia).

- Article 13 - facilitate the reunification of families (Mexico and Slovakia).

- Article 14 - geographical mobility (Belgium, Germany, Mauritius and Slovakia).

\section{General obstacles}

- The Conventions are not in line with current national laws and practice (Czech Republic, Finland, Japan, Kuwait, Slovakia, Switzerland and United Kingdom).

- Follow-up procedures and elaboration of reports requested upon ratification (United Arab Emirates).

- Conventions are inflexible with respect to the member States' systems and procedures, e.g. the social security system (in particular provisions that grant migrants and their families the same conditions as nationals, that offer the same rights for irregular migrants and with respect to family reunification) (Denmark).

Remarks

A relatively small number of the respondents replied that they intended to ratify either of the Conventions. However, only a handful of the member States specified obstacles that prevented ratification of the Conventions, the main reason stated being that the Conventions were not in line with national laws and regulations in this area.

- Question 42. With respect to the following ILO Conventions and Recommendations, please indicate if you have used or intend to use them as models for your national law and practice in this area.

Survey response

\section{Impact of ILO instruments in the responding countries}

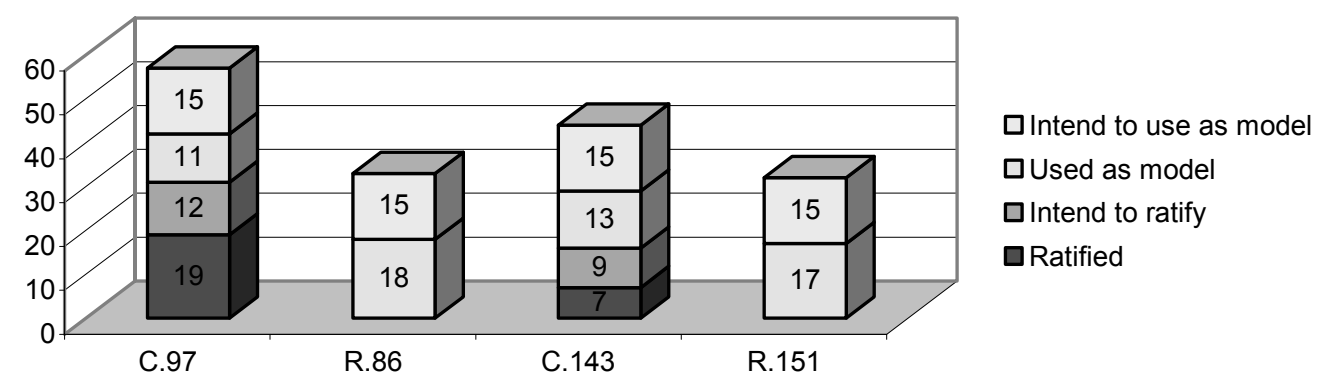

\section{Remarks}

Based on the results of the Survey, both Conventions Nos. 97 and 143 appear to have impacted, either directly (ratification) or indirectly (being used, or intended to be used, as a model), on national laws and regulations, i.e. in 63 per cent of countries for Convention No. 97 and 49 per cent of countries for Convention No. 143. Conventions Nos. 97 and 143 have been ratified by 42 and 18 member States, respectively. 
a Question 43. Please explain if current ILO instruments in this area (including but not limited to Conventions Nos. 97 and 143) contain any significant gaps or lacunae that you consider should be addressed by the ILO.

Survey response

Gaps

- Conventions Nos. 97 and 143 are not specific enough.

- Self-employed persons are not included in the scope of Convention No. 97.

- There is no clear definition of the term "family" in Convention No. 97.

- Regularization of irregular migrants.

- Documentation for temporary migrant workers (Convention No. 97).

- Trafficking.

- Lack of social protection of migrant workers in particular with respect to benefits.

- Need to develop new strategies in reaction to the changes in migration brought about by globalization.

- ILO instruments need to be harmonized with other international instruments such as GATS Mode 4 or the International Convention on the Protection of the Rights of All Migrant Workers and Members of their Families, 1990.

\section{Remarks}

Only 29 of the respondents provided comments on this question. Fourteen replied that the Conventions were sufficiently comprehensive and that there were no gaps or lacunae.

प Question 44. Are there any specific concerns that you consider should be the object of ILO action in the present subject area?

A. If yes, please specify.

B. Indicate whether these concerns should be addressed in the context of developing:

(a) A new Convention.

(b) A new Recommendation.

(c) Revision of exiting instruments.

(d) Codes of practice.

(e) Other types of guidelines.

(f) Other action (if yes, please specify below). 
Survey response

\section{How to address specific concerns}

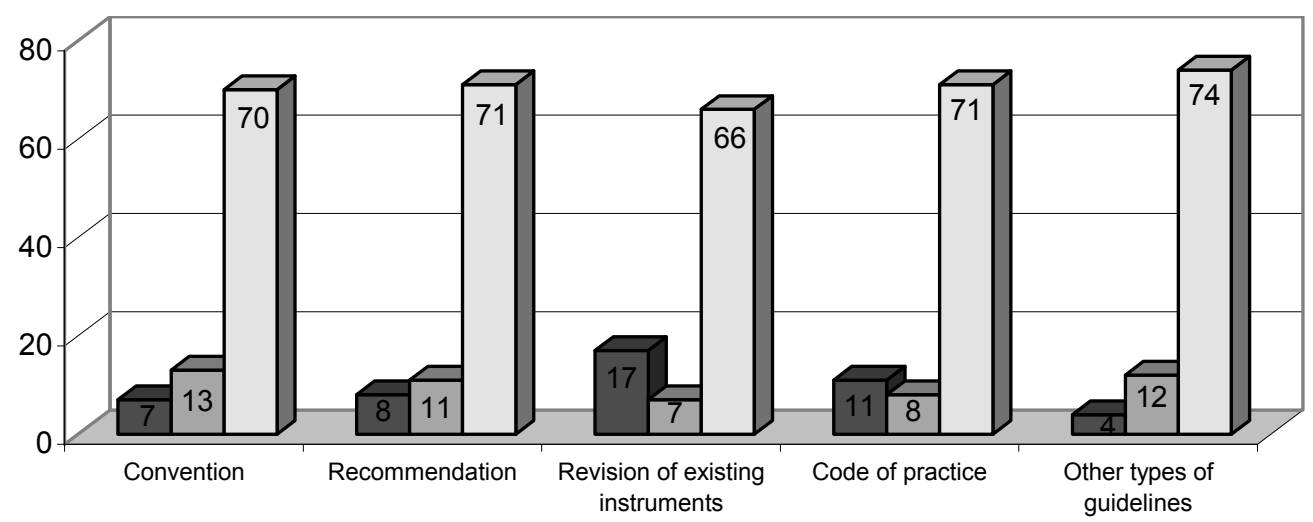

Specific concerns to be the object of ILO action

- Protection of irregular migrant workers and their families.

- Protection of temporary migrant workers.

- Protection of domestic migrant workers.

- Social protection of migrant workers.

- Family reunification.

- Examination of the advantages and disadvantages of labour migration in countries and regions, and identification of the impact of migration in receiving countries.

- Combating human trafficking, e.g. through information dissemination.

- Elaboration of guidelines for bilateral agreements.

- Avoidance of social dumping and creation of a policy combating the brain drain in developing countries.

- Revision of Article 8 of Convention No. 97.

- Application and promotion of existing instruments.

\section{Remarks}

Only 27 replies were received on the above question. Among these replies, the protection of certain groups, such as irregular or temporary migrant workers or domestic workers, was often cited. 


\subsection{Technical cooperation required from the ILO}

a Question 45. Please indicate whether you need technical cooperation from the ILO with regard to migration for employment in any of the following areas:
A. Development of labour migration policy.
B. Review and/or reform of applicable legislation.
C. Development of national administrative infrastructures.
D. Building capacity of workers' and employers' organizations.
E. Strengthening labour inspection.
F. Promotion of equality of treatment for migrant workers.
G. Improved statistics on migration.
H. Gender-specific issues of migration policy or practice.

Survey response

\section{Technical cooperation}

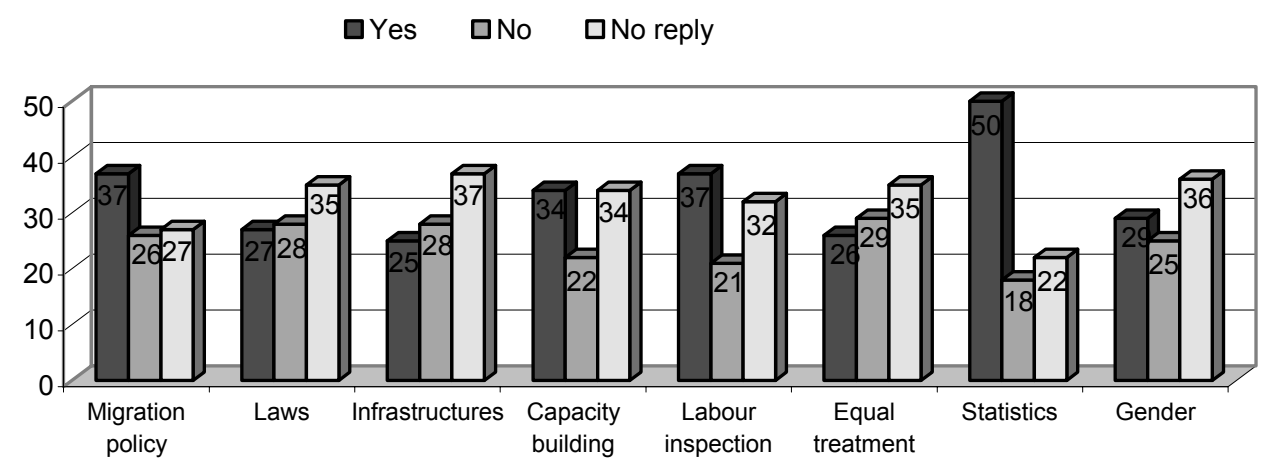

\subsection{Information that would be useful for policy-making and administration}

a Question 46. Please specify below what kind of information on labour migration would be useful to you in policy-making and administration

\section{Survey response}

The 37 respondents that replied to this question indicated that more information on the following topics would be useful to them in policy-making and administration:

- Specific country information on policies, laws, regulations and best practices in member States, for example by way of a comparative analysis of countries and/or database etc. (Albania, Austria, Canada, Costa Rica, Cyprus, Egypt, Ethiopia, Japan, Kenya, Lebanon, Mexico, Pakistan, Panama, Rwanda, Tajikistan, Togo, Ukraine and United Arab Emirates).

- Statistics (Albania, Argentina, Bahrain, Belgium, Ecuador, France, Honduras, Hungary, Kenya, Netherlands, Nicaragua, Pakistan, Slovakia and Sudan) as well as the Barbados Workers' Union. In addition, the following countries indicated that they needed technical cooperation for improving labour statistics in this area: Albania, Algeria, Argentina, Armenia, Bahrain, Belarus, Bolivia, Brazil, Bulgaria, 
Colombia, Costa Rica, Czech Republic, Ecuador, Egypt, El Salvador, Eritrea, Estonia, Ethiopia, France, Guatemala, Honduras, Kazakhstan, Kenya, Republic of Korea, Lebanon, Madagascar, Mauritius, Morocco, Nicaragua, Oman, Pakistan, Romania, Rwanda, Senegal, Seychelles, Slovakia, South Africa, Sri Lanka, Sudan, Switzerland, Syrian Arab Republic, Tajikistan, Thailand, Togo, Tunisia, United Arab Emirates, Uruguay and Zimbabwe.

- Regional and interregional migration flows (Argentina, Japan and Zimbabwe).

- Solutions for issues concerning the "brain drain" (Armenia).

- Employment abroad, foreign market needs, etc. (Armenia, Egypt and Ethiopia).

Remarks

There were two main trends that came out of the replies to this question. First was the need for specific information, by country, on different aspects of migration, including laws, policies, and employment opportunities, etc. The second was a need for reliable and detailed statistics in this area.

\section{Completion of the Survey}

a Question 51. Regarding the completion of this Survey:

A. Were the most representative employers' organizations consulted in its preparation?

B. Were the most representative workers' organizations consulted in its preparation?

C. Was there consultation with any governmental authorities outside the ministry responsible for labour?

- Question 52. Regarding comments received on this Survey:

A. Did employers' organizations make any comments on the Survey?

B. Did workers' organizations make any comments on the Survey?

Survey response

\section{Table 8. Consultations and comments}

\begin{tabular}{llrrr}
\hline Q.51 & & Yes & No & No reply \\
\hline A $^{*}$ & $\begin{array}{l}\text { Most representative employers' organizations consulted on the } \\
\text { preparation of the Survey }\end{array}$ & 50 & 13 & 26 \\
B $^{*}$ & $\begin{array}{l}\text { Most representative workers' organizations consulted on the } \\
\text { preparation of the Survey }\end{array}$ & 49 & 14 & 26 \\
C & Governmental authorities were consulted on Survey & 51 & 13 & 25 \\
Q.52 & & & & \\
$A^{* *}$ & Employers' organizations made comments on the Survey & 25 & 41 & 24 \\
$B^{* * *}$ & Workers' organizations made comments on the Survey & 19 & 41 & 30
\end{tabular}

* Algeria, Argentina, Australia, Austria, Bahrain, Belarus, Belgium, Bulgaria, Burundi, Canada, China, Cyprus, Czech Republic, Estonia, Ethiopia, Finland, France, Germany, Greece, Iceland, Ireland, Japan, Kenya, Republic of Korea, Kuwait, Lebanon, Mauritius, Mexico, Myanmar, Netherlands, New Zealand, Philippines, Poland, Portugal, Qatar, Romania, Rwanda, Slovakia, Sri Lanka, Sudan, Sweden, Switzerland, Syrian Arab Republic, Tajikistan, Togo, Uganda, United Kingdom, United States, Uruguay. Oman indicated that only the most representative employers' organizations had been consulted. In addition, a survey response was received from a workers' organization in Barbados. ${ }^{* *}$ Algeria, Belgium, Brazil, Cyprus, Czech Republic, Ecuador, Finland, France, Germany, Iceland, Japan, Republic of Korea, Kuwait, Mexico, Myanmar, New Zealand, Norway, Poland, Rwanda, Sweden, Switzerland, Uganda, United Kingdom, United States, Uruguay. ${ }^{* * *}$ Algeria, Austria, Belgium, Cyprus, Czech Republic, Estonia, Finland, France, Iceland, Japan, Malaysia, Myanmar, Norway, Rwanda, Spain, Sweden, Switzerland, United States, Uruguay. 


\section{Annex II}

\section{Ratifications of relevant instruments (as at March 2004)}

Convention No. 97: Migration for Employment Convention (Revised), 1949 (No. 97):

Date of entry into force: 22 January 1952 ,

42 ratifications. ${ }^{1}$

Convention No. 143: Migrant Workers (Supplementary Provisions) Convention, 1975 (No. 143):

Date of entry into force: 9 December 1978,

18 ratifications.

1990 United Nations Convention: International Convention on the Protection of the Rights of All Migrant Workers and Members of Their Families:

Date of entry into force: 1 July 2003,

25 ratifications.

\begin{tabular}{llll}
\hline State & Convention No. 97 & Convention No. 143 & $\begin{array}{l}\text { United Nations Convention } \\
\text { (migrants) }\end{array}$ \\
\hline Algeria & 19.10 .1962 & & 11.01 .1999 \\
Azerbaijan & 25.05 .1976 & & \\
Bahamas & 08.05 .1967 & & 14.11 .2001 \\
Barbados & 27.07 .1953 & & 12.10 .2000 \\
Belgium & 15.12 .1983 & 11.06 .1980 & 13.12 .1996 \\
Belize & & & \\
Benin & & 02.06 .1993 & \\
Bolivia & 02.06 .1993 & & 26.11 .2003 \\
Bosnia and Herzegovina & 18.06 .1965 & 09.12 .1977 & \\
Brazil & 09.06 .1961 & & \\
Burkina Faso & & & \\
\hline
\end{tabular}

\footnotetext{
${ }^{1}$ Convention No. 97 is also applicable to Hong Kong, China, by virtue of a notification of application by China, and to Anguilla (with certain modifications), Jersey, Guernsey, British Virgin Islands (with certain modifications), Montserrat (with certain modifications) and the Isle of Man by virtue of declarations of application by the United Kingdom.
} 


\begin{tabular}{|c|c|c|c|}
\hline State & Convention No. 97 & Convention No. 143 & $\begin{array}{l}\text { United Nations Convention } \\
\text { (migrants) }\end{array}$ \\
\hline Cameroon & 03.09 .1962 & 04.07 .1978 & \\
\hline Cape Verde & & & 16.09.1997 \\
\hline Colombia & & & 24.05 .1995 \\
\hline Cuba & 29.04 .1952 & & \\
\hline Cyprus & 23.09 .1960 & 28.06.1977 & \\
\hline Dominica & 28.02 .1983 & & \\
\hline Ecuador & 05.04 .1978 & & 06.02 .2002 \\
\hline El Salvador & & & 14.03 .2003 \\
\hline Egypt & & & 19.02 .1993 \\
\hline France & 29.03 .1953 & & \\
\hline Germany & 22.03 .1959 & & \\
\hline Ghana & & & 08.09 .2000 \\
\hline Grenada & 09.07 .1952 & & \\
\hline Guatemala & 13.02 .1952 & & 14.03 .2003 \\
\hline Guinea & & 05.06 .1978 & 08.09 .2000 \\
\hline Guyana & 08.06 .1966 & & \\
\hline Israel & 30.03 .1953 & & \\
\hline Italy & 22.10 .1952 & 23.06.1981 & \\
\hline Jamaica & 22.06 .1962 & & \\
\hline Kenya & 30.11 .1965 & 09.04 .1979 & \\
\hline Kyrgyzstan & & & 29.09 .2003 \\
\hline Madagascar & 14.06 .2001 & & \\
\hline Malawi & 22.03 .1965 & & \\
\hline Malaysia & 03.03 .1964 & & \\
\hline Mali & & & 06.06 .2003 \\
\hline Mauritius & 02.12 .1969 & & \\
\hline Mexico & & & 08.03.1999 \\
\hline Morocco & & & 21.06 .1993 \\
\hline Netherlands & 20.05 .1952 & & \\
\hline New Zealand & 10.11 .1950 & & \\
\hline Nigeria & 17.02 .1955 & & \\
\hline Norway & 17.02 .1955 & 24.01 .1979 & \\
\hline Philippines & & & 05.07 .1995 \\
\hline Portugal & 12.12 .1978 & 12.12 .1978 & \\
\hline Saint Lucia & 14.05 .1980 & & \\
\hline
\end{tabular}




\begin{tabular}{|c|c|c|c|}
\hline State & Convention No. 97 & Convention No. 143 & $\begin{array}{l}\text { United Nations Convention } \\
\text { (migrants) }\end{array}$ \\
\hline San Marino & & 23.05 .1985 & \\
\hline Senegal & & & 09.06 .1999 \\
\hline Seychelles & & & 15.12 .1994 \\
\hline Serbia and Montenegro & 24.11 .2000 & 24.11 .2000 & \\
\hline Slovenia & 29.05 .1992 & 29.05.1992 & \\
\hline Spain & 21.03 .1967 & & \\
\hline Sri Lanka & & & 11.03 .1996 \\
\hline Sweden & & 28.12.1982 & \\
\hline Tajikistan & & & 08.01 .2002 \\
\hline Tanzania, United Rep. of & 22.06 .1966 & & \\
\hline $\begin{array}{l}\text { The former Yugoslav Republic } \\
\text { of Macedonia }\end{array}$ & 17.11.1991 & 17.11.1991 & \\
\hline Trinidad and Tobago & 24.05 .1963 & & \\
\hline Timor-Leste & & & 30.01 .2004 \\
\hline Togo & & 08.11 .1983 & \\
\hline Uganda & & 31.03 .1978 & 14.11.1995 \\
\hline United Kingdom & 22.01 .1951 & & \\
\hline Uruguay & 18.03 .1953 & & 15.02 .2001 \\
\hline Venezuela & 09.06 .1963 & 09.06 .1963 & \\
\hline Zambia & 02.12 .1964 & & \\
\hline
\end{tabular}




\section{Annex III}

\section{Texts of the ILO instruments on migrant workers}

\section{Migration for Employment Convention (Revised), 1949 (No. 97)}

The General Conference of the International Labour Organisation,

Having been convened at Geneva by the Governing Body of the International Labour Office, and having met in its Thirty-second Session on 8 June 1949, and

Having decided upon the adoption of certain proposals with regard to the revision of the Migration for Employment Convention, 1939, adopted by the Conference at its Twenty-fifth Session, which is included in the eleventh item on the agenda of the session, and

Considering that these proposals must take the form of an international Convention,

adopts this first day of July of the year one thousand nine hundred and forty-nine the following Convention, which may be cited as the Migration for Employment Convention (Revised), 1949:

\section{Article 1}

Each Member of the International Labour Organisation for which this Convention is in force undertakes to make available on request to the International Labour Office and to other Members -

(a) information on national policies, laws and regulations relating to emigration and immigration;

(b) information on special provisions concerning migration for employment and the conditions of work and livelihood of migrants for employment;

(c) information concerning general agreements and special arrangements on these questions concluded by the Member.

\section{Article 2}

Each Member for which this Convention is in force undertakes to maintain, or satisfy itself that there is maintained, an adequate and free service to assist migrants for employment, and in particular to provide them with accurate information.

\section{Article 3}

1. Each Member for which this Convention is in force undertakes that it will, so far as national laws and regulations permit, take all appropriate steps against misleading propaganda relating to emigration and immigration. 
2. For this purpose, it will where appropriate act in co-operation with other Members concerned.

\section{Article 4}

Measures shall be taken as appropriate by each Member, within its jurisdiction, to facilitate the departure, journey and reception of migrants for employment.

\section{Article 5}

Each Member for which this Convention is in force undertakes to maintain, within its jurisdiction, appropriate medical services responsible for -

(a) ascertaining, where necessary, both at the time of departure and on arrival, that migrants for employment and the members of their families authorised to accompany or join them are in reasonable health;

(b) ensuring that migrants for employment and members of their families enjoy adequate medical attention and good hygienic conditions at the time of departure, during the journey and on arrival in the territory of destination.

\section{Article 6}

1. Each Member for which this Convention is in force undertakes to apply, without discrimination in respect of nationality, race, religion or sex, to immigrants lawfully within its territory, treatment no less favourable than that which it applies to its own nationals in respect of the following matters:

(a) in so far as such matters are regulated by law or regulations, or are subject to the control of administrative authorities -

(i) remuneration, including family allowances where these form part of remuneration, hours of work, overtime arrangements, holidays with pay, restrictions on home work, minimum age for employment, apprenticeship and training, women's work and the work of young persons;

(ii) membership of trade unions and enjoyment of the benefits of collective bargaining;

(iii) accommodation;

(b) social security (that is to say, legal provision in respect of employment injury, maternity, sickness, invalidity, old age, death, unemployment and family responsibilities, and any other contingency which, according to national laws or regulations, is covered by a social security scheme), subject to the following limitations:

(i) there may be appropriate arrangements for the maintenance of acquired rights and rights in course of acquisition;

(ii) national laws or regulations of immigration countries may prescribe special arrangements concerning benefits or portions of benefits which are payable wholly out of public funds, and concerning allowances paid to persons who do not fulfil the contribution conditions prescribed for the award of a normal pension;

(c) employment taxes, dues or contributions payable in respect of the person employed; and

(d) legal proceedings relating to the matters referred to in this Convention.

2. In the case of a federal State the provisions of this Article shall apply in so far as the matters dealt with are regulated by federal law or regulations or are subject to the control of federal administrative authorities. The extent to which and manner in which these provisions shall be applied in respect of matters regulated by the law or regulations of the constituent 
States, provinces or cantons, or subject to the control of the administrative authorities thereof, shall be determined by each Member. The Member shall indicate in its annual report upon the application of the Convention the extent to which the matters dealt with in this Article are regulated by federal law or regulations or are subject to the control of federal administrative authorities. In respect of matters which are regulated by the law or regulations of the constituent States, provinces or cantons, or are subject to the control of the administrative authorities thereof, the Member shall take the steps provided for in paragraph 7(b) of article 19 of the Constitution of the International Labour Organisation.

\section{Article 7}

1. Each Member for which this Convention is in force undertakes that its employment service and other services connected with migration will co-operate in appropriate cases with the corresponding services of other Members.

2. Each Member for which this Convention is in force undertakes to ensure that the services rendered by its public employment service to migrants for employment are rendered free.

\section{Article 8}

1. A migrant for employment who has been admitted on a permanent basis and the members of his family who have been authorised to accompany or join him shall not be returned to their territory of origin or the territory from which they emigrated because the migrant is unable to follow his occupation by reason of illness contracted or injury sustained subsequent to entry, unless the person concerned so desires or an international agreement to which the Member is a party so provides.

2. When migrants for employment are admitted on a permanent basis upon arrival in the country of immigration the competent authority of that country may determine that the provisions of paragraph 1 of this Article shall take effect only after a reasonable period which shall in no case exceed five years from the date of admission of such migrants.

\section{Article 9}

Each Member for which this Convention is in force undertakes to permit, taking into account the limits allowed by national laws and regulations concerning export and import of currency, the transfer of such part of the earnings and savings of the migrant for employment as the migrant may desire.

Article 10

In cases where the number of migrants going from the territory of one Member to that of another is sufficiently large, the competent authorities of the territories concerned shall, whenever necessary or desirable, enter into agreements for the purpose of regulating matters of common concern arising in connection with the application of the provisions of this Convention.

\section{Article 11}

1. For the purpose of this Convention the term migrant for employment means a person who migrates from one country to another with a view to being employed otherwise than on his own account and includes any person regularly admitted as a migrant for employment.

2. This Convention does not apply to -

(a) frontier workers; 
(b) short-term entry of members of the liberal professions and artistes; and

(c) seamen.

\section{Article 12}

The formal ratifications of this Convention shall be communicated to the DirectorGeneral of the International Labour Office for registration.

\section{Article 13}

1. This Convention shall be binding only upon those Members of the International Labour Organisation whose ratifications have been registered with the Director-General.

2. It shall come into force twelve months after the date on which the ratifications of two Members have been registered with the Director-General.

3. Thereafter, this Convention shall come into force for any Member twelve months after the date on which its ratification has been registered.

Article 14

1. Each Member ratifying this Convention may, by a declaration appended to its ratification, exclude from its ratification any or all of the Annexes to the Convention.

2. Subject to the terms of any such declaration, the provisions of the Annexes shall have the same effect as the provisions of the Convention.

3. Any Member which makes such a declaration may subsequently by a new declaration notify the Director-General that it accepts any or all of the Annexes mentioned in the declaration; as from the date of the registration of such notification by the DirectorGeneral the provisions of such Annexes shall be applicable to the Member in question.

4. While a declaration made under paragraph 1 of this Article remains in force in respect of any Annex, the Member may declare its willingness to accept that Annex as having the force of a Recommendation.

\section{Article 15}

1. Declarations communicated to the Director-General of the International Labour Office in accordance with paragraph 2 of Article 35 of the Constitution of the International Labour Organisation shall indicate -

(a) the territories in respect of which the Member concerned undertakes that the provisions of the Convention and any or all of the Annexes shall be applied without modification;

(b) the territories in respect of which it undertakes that the provisions of the Convention and any or all of the Annexes shall be applied subject to modifications, together with details of the said modifications;

(c) the territories in respect of which the Convention and any or all of the Annexes are inapplicable and in such cases the grounds on which they are inapplicable;

(d) the territories in respect of which it reserves its decision pending further consideration of the position.

2. The undertakings referred to in subparagraphs (a) and (b) of paragraph 1 of this Article shall be deemed to be an integral part of the ratification and shall have the force of ratification. 
3. Any Member may at any time by a subsequent declaration cancel in whole or in part any reservations made in its original declaration in virtue of subparagraph (b), (c) or (d) of paragraph 1 of this Article.

4. Any Member may, at any time at which the Convention is subject to denunciation in accordance with the provisions of Article 17, communicate to the Director-General a declaration modifying in any other respect the terms of any former declaration and stating the present position in respect of such territories as it may specify.

Article 16

1. Declarations communicated to the Director-General of the International Labour Office in accordance with paragraph 4 or 5 of Article 35 of the Constitution of the International Labour Organisation shall indicate whether the provisions of the Convention and any or all of the Annexes will be applied in the territory concerned without modification or subject to modifications; and if the declaration indicates that the provisions of the Convention and any or all of the Annexes will be applied subject to modifications, it shall give details of the said modifications.

2. The Member, Members or international authority concerned may at any time by a subsequent declaration renounce in whole or in part the right to have recourse to any modification indicated in any former declaration.

3. The Member, Members or international authority concerned may, at any time at which this Convention and any or all of the Annexes are subject to denunciation in accordance with the provisions of Article 17, communicate to the Director-General a declaration modifying in any other respect the terms of any former declaration and stating the present position in respect of the application of the Convention.

\section{Article 17}

1. A Member which has ratified this Convention may denounce it after the expiration of ten years from the date on which the Convention first comes into force, by an act communicated to the Director-General of the International Labour Office for registration. Such denunciation shall not take effect until one year after the date on which it is registered.

2. Each Member which has ratified this Convention and which does not, within the year following the expiration of the period of ten years mentioned in the preceding paragraph, exercise the right of denunciation provided for in this Article, will be bound for another period of ten years and, thereafter, may denounce this Convention at the expiration of each period of ten years under the terms provided for in this Article.

3. At any time at which this Convention is subject to denunciation in accordance with the provisions of the preceding paragraphs any Member which does not so denounce it may communicate to the Director-General a declaration denouncing separately any Annex to the Convention which is in force for that Member.

4. The denunciation of this Convention or of any or all of the Annexes shall not affect the rights granted thereunder to a migrant or to the members of his family if he immigrated while the Convention or the relevant Annex was in force in respect of the territory where the question of the continued validity of these rights arises.

\section{Article 18}

1. The Director-General of the International Labour Office shall notify all Members of the International Labour Organisation of the registration of all ratifications, declarations and denunciations communicated to him by the Members of the Organisation. 
2. When notifying the Members of the Organisation of the registration of the second ratification communicated to him, the Director-General shall draw the attention of the Members of the Organisation to the date upon which the Convention will come into force.

\section{Article 19}

The Director-General of the International Labour Office shall communicate to the Secretary-General of the United Nations for registration in accordance with Article 102 of the Charter of the United Nations full particulars of all ratifications, declarations and acts of denunciation registered by him in accordance with the provisions of the preceding articles.

\section{Article 20}

At such times as it may consider necessary the Governing Body of the International Labour Office shall present to the General Conference a report on the working of this Convention and shall examine the desirability of placing on the agenda of the Conference the question of its revision in whole or in part.

\section{Article 21}

1. Should the Conference adopt a new Convention revising this Convention in whole or in part, then, unless the new Convention otherwise provides -

(a) the ratification by a Member of the new revising Convention shall ipso jure involve the immediate denunciation of this Convention, notwithstanding the provisions of Article 17 above, if and when the new revising Convention shall have come into force;

(b) as from the date when the new revising Convention comes into force this Convention shall cease to be open to ratification by the Members.

2. This Convention shall in any case remain in force in its actual form and content for those Members which have ratified it but have not ratified the revising Convention.

\section{Article 22}

1. The International Labour Conference may, at any session at which the matter is included in its agenda, adopt by a two-thirds majority a revised text of any one or more of the Annexes to this Convention.

2. Each Member for which this Convention is in force shall, within the period of one year, or, in exceptional circumstances, of eighteen months, from the closing of the session of the Conference, submit any such revised text to the authority or authorities within whose competence the matter lies, for the enactment of legislation or other action.

3. Any such revised text shall become effective for each Member for which this Convention is in force on communication by that Member to the Director-General of the International Labour Office of a declaration notifying its acceptance of the revised text.

4. As from the date of the adoption of the revised text of the Annex by the Conference, only the revised text shall be open to acceptance by Members.

\section{Article 23}

The English and French versions of the text of this Convention are equally authoritative. 


\section{ANNEX I \\ RECRUITMENT, PLACING AND CONDITIONS OF LABOUR OF MIGRANTS FOR EMPLOYMENT RECRUITED OTHERWISE THAN UNDER GOVERNMENT-SPONSORED ARRANGEMENTS FOR GROUP TRANSFER}

\section{Article 1}

This Annex applies to migrants for employment who are recruited otherwise than under Government-sponsored arrangements for group transfer.

Article 2

For the purpose of this Annex -

(a) the term "recruitment" means -

(i) the engagement of a person in one territory on behalf of an employer in another territory, or

(ii) the giving of an undertaking to a person in one territory to provide him with employment in another territory,

together with the making of any arrangements in connection with the operations mentioned in (i) and (ii) including the seeking for and selection of emigrants and the preparation for departure of the emigrants;

(b) the term "introduction" means any operations for ensuring or facilitating the arrival in or admission to a territory of persons who have been recruited within the meaning of paragraph (a) of this Article; and

(c) the term "placing" means any operations for the purpose of ensuring or facilitating the employment of persons who have been introduced within the meaning of paragraph (b) of this Article.

Article 3

1. Each Member for which this Annex is in force, the laws and regulations of which permit the operations of recruitment, introduction and placing as defined in Article 2, shall regulate such of the said operations as are permitted by its laws and regulations in accordance with the provisions of this Article.

2. Subject to the provisions of the following paragraph, the right to engage in the operations of recruitment, introduction and placing shall be restricted to -

(a) public employment offices or other public bodies of the territory in which the operations take place;

(b) public bodies of a territory other than that in which the operations take place which are authorised to operate in that territory by agreement between the Governments concerned;

(c) any body established in accordance with the terms of an international instrument.

3. In so far as national laws and regulations or a bilateral arrangement permit, the operations of recruitment, introduction and placing may be undertaken by -

(a) the prospective employer or a person in his service acting on his behalf, subject, if necessary in the interest of the migrant, to the approval and supervision of the competent authority; 
(b) a private agency, if given prior authorisation so to do by the competent authority of the territory where the said operations are to take place, in such cases and under such conditions as may be prescribed by -

(i) the laws and regulations of that territory, or

(ii) agreement between the competent authority of the territory of emigration or any body established in accordance with the terms of an international instrument and the competent authority of the territory of immigration.

4. The competent authority of the territory where the operations take place shall supervise the activities of bodies and persons to whom authorisations have been issued in pursuance of paragraph 3 (b), other than any body established in accordance with the terms of an international instrument, the position of which shall continue to be governed by the terms of the said instrument or by any agreement made between the body and the competent authority concerned.

5. Nothing in this Article shall be deemed to permit the acceptance of a migrant for employment for admission to the territory of any Member by any person or body other than the competent authority of the territory of immigration.

\section{Article 4}

Each Member for which this Annex is in force undertakes to ensure that the services rendered by its public employment service in connection with the recruitment, introduction or placing of migrants for employment are rendered free.

\section{Article 5}

1. Each Member for which this Annex is in force which maintains a system of supervision of contracts of employment between an employer, or a person acting on his behalf, and a migrant for employment undertakes to require -

(a) that a copy of the contract of employment shall be delivered to the migrant before departure or, if the Governments concerned so agree, in a reception centre on arrival in the territory of immigration;

(b) that the contract shall contain provisions indicating the conditions of work and particularly the remuneration offered to the migrant;

(c) that the migrant shall receive in writing before departure, by a document which relates either to him individually or to a group of migrants of which he is a member, information concerning the general conditions of life and work applicable to him in the territory of immigration.

2. Where a copy of the contract is to be delivered to the migrant on arrival in the territory of immigration, he shall be informed in writing before departure, by a document which relates either to him individually or to a group of migrants of which he is a member, of the occupational category for which he is engaged and the other conditions of work, in particular the minimum wage which is guaranteed to him.

3. The competent authority shall ensure that the provisions of the preceding paragraphs are enforced and that appropriate penalties are applied in respect of violations thereof.

\section{Article 6}

The measures taken under Article 4 of the Convention shall, as appropriate, include -

(a) the simplification of administrative formalities; 
(b) the provision of interpretation services;

(c) any necessary assistance during an initial period in the settlement of the migrants and members of their families authorised to accompany or join them; and

(d) the safeguarding of the welfare, during the journey and in particular on board ship, of migrants and members of their families authorised to accompany or join them.

\section{Article 7}

1. In cases where the number of migrants for employment going from the territory of one Member to that of another is sufficiently large, the competent authorities of the territories concerned shall, whenever necessary or desirable, enter into agreements for the purpose of regulating matters of common concern arising in connection with the application of the provisions of this Annex.

2. Where the members maintain a system of supervision over contracts of employment, such agreements shall indicate the methods by which the contractual obligations of the employers shall be enforced.

Article 8

Any person who promotes clandestine or illegal immigration shall be subject to appropriate penalties.

\section{ANNEX II \\ RECRUITMENT, PLACING AND CONDITIONS OF LABOUR OF MIGRANTS FOR EMPLOYMENT RECRUITED UNDER GOVERNMENT-SPONSORED ARRANGEMENTS FOR GROUP TRANSFER}

Article 1

This Annex applies to migrants for employment who are recruited under Governmentsponsored arrangements for group transfer.

Article 2

For the purpose of this Annex -

(a) the term "recruitment" means -

(i) the engagement of a person in one territory on behalf of an employer in another territory under a Government-sponsored arrangement for group transfer, or

(ii) the giving of an undertaking to a person in one territory to provide him with employment in another territory under a Government-sponsored arrangement for group transfer, together with the making of any arrangements in connection with the operations mentioned in (i) and (ii) including the seeking for and selection of emigrants and the preparation for departure of the emigrants;

(b) the term "introduction" means any operations for ensuring or facilitating the arrival in or admission to a territory of persons who have been recruited under a Governmentsponsored arrangement for group transfer within the meaning of subparagraph (a) of this paragraph; and

(c) the term "placing" means any operations for the purpose of ensuring or facilitating the employment of persons who have been introduced under a Government-sponsored 
arrangement for group transfer within the meaning of subparagraph (b) of this paragraph.

\section{Article 3}

1. Each Member for which this Annex is in force, the laws and regulations of which permit the operations of recruitment, introduction and placing as defined in Article 2, shall regulate such of the said operations as are permitted by its laws and regulations in accordance with the provisions of this Article.

2. Subject to the provisions of the following paragraph, the right to engage in the operations of recruitment, introduction and placing shall be restricted to -

(a) public employment offices or other public bodies of the territory in which the operations take place;

(b) public bodies of a territory other than that in which the operations take place which are authorised to operate in that territory by agreement between the Governments concerned;

(c) any body established in accordance with the terms of an international instrument.

3. In so far as national laws and regulations or a bilateral arrangement permit, and subject, if necessary in the interest of the migrant, to the approval and supervision of the competent authority, the operations of recruitment, introduction and placing may be undertaken by -

(a) the prospective employer or a person in his service acting on his behalf;

(b) private agencies.

4. The right to engage in the operations of recruitment, introduction and placing shall be subject to the prior authorisation of the competent authority of the territory where the said operations are to take place in such cases and under such conditions as may be prescribed by -

(a) the laws and regulations of that territory, or

(b) agreement between the competent authority of the territory of emigration or any body established in accordance with the terms of an international instrument and the competent authority of the territory of immigration.

5. The competent authority of the territory where the operations take place shall, in accordance with any agreements made between the competent authorities concerned, supervise the activities of bodies and persons to whom authorisations have been issued in pursuance of the preceding paragraph, other than any body established in accordance with the terms of an international instrument, the position of which shall continue to be governed by the terms of the said instrument or by any agreement made between the body and the competent authority concerned.

6. Before authorising the introduction of migrants for employment the competent authority of the territory of immigration shall ascertain whether there is not a sufficient number of persons already available capable of doing the work in question.

7. Nothing in this Article shall be deemed to permit the acceptance of a migrant for employment for admission to the territory of any Member by any person or body other than the competent authority of the territory of immigration. 


\section{Article 4}

1. Each Member for which this Annex is in force undertakes to ensure that the services rendered by its public employment service in connection with the recruitment, introduction or placing of migrants for employment are rendered free.

2. The administrative costs of recruitment, introduction and placing shall not be borne by the migrants.

\section{Article 5}

In the case of collective transport of migrants from one country to another necessitating passage in transit through a third country, the competent authority of the territory of transit shall take measures for expediting the passage, to avoid delays and administrative difficulties.

\section{Article 6}

1. Each Member for which this Annex is in force which maintains a system of supervision of contracts of employment between an employer, or a person acting on his behalf, and a migrant for employment undertakes to require -

(a) that a copy of the contract of employment shall be delivered to the migrant before departure or, if the Governments concerned so agree, in a reception centre on arrival in the territory of immigration;

(b) that the contract shall contain provisions indicating the conditions of work and particularly the remuneration offered to the migrant;

(c) that the migrant shall receive in writing before departure, by a document which relates either to him individually or to a group of migrants of which he is a member, information concerning the general conditions of life and work applicable to him in the territory of immigration.

2. Where a copy of the contract is to be delivered to the migrant on arrival in the territory of immigration, he shall be informed in writing before departure, by a document which relates either to him individually or to a group of migrants of which he is a member, of the occupational category for which he is engaged and the other conditions of work, in particular the minimum wage which is guaranteed to him.

3. The competent authority shall ensure that the provisions of the preceding paragraphs are enforced and that appropriate penalties are applied in respect of violations thereof.

\section{Article 7}

1. The measures taken under Article 4 of this Convention shall, as appropriate, include -

(a) the simplification of administrative formalities;

(b) the provision of interpretation services;

(c) any necessary assistance, during an initial period in the settlement of the migrants and members of their families authorised to accompany or join them;

(d) the safeguarding of the welfare, during the journey and in particular on board ship, of migrants and members of their families authorised to accompany or join them; and

(e) permission for the liquidation and transfer of the property of migrants for employment admitted on a permanent basis. 


\section{Article 8}

Appropriate measures shall be taken by the competent authority to assist migrants for employment, during an initial period, in regard to matters concerning their conditions of employment; where appropriate, such measures may be taken in co-operation with approved voluntary organisations.

\section{Article 9}

If a migrant for employment introduced into the territory of a Member in accordance with the provisions of Article 3 of this Annex fails, for a reason for which he is not responsible, to secure the employment for which he has been recruited or other suitable employment, the cost of his return and that of the members of his family who have been authorised to accompany or join him, including administrative fees, transport and maintenance charges to the final destination, and charges for the transport of household belongings, shall not fall upon the migrant.

\section{Article 10}

If the competent authority of the territory of immigration considers that the employment for which a migrant for employment was recruited under Article 3 of this Annex has been found to be unsuitable, it shall take appropriate measures to assist him in finding suitable employment which does not prejudice national workers and shall take such steps as will ensure his maintenance pending placing in such employment, or his return to the area of recruitment if the migrant is willing or agreed to such return at the time of his recruitment, or his resettlement elsewhere.

\section{Article 11}

If a migrant for employment who is a refugee or a displaced person and who has entered a territory of immigration in accordance with Article 3 of this Annex becomes redundant in any employment in that territory, the competent authority of that territory shall use its best endeavours to enable him to obtain suitable employment which does not prejudice national workers, and shall take such steps as will ensure his maintenance pending placing in suitable employment or his resettlement elsewhere.

\section{Article 12}

1. The competent authorities of the territories concerned shall enter into agreements for the purpose of regulating matters of common concern arising in connection with the application of the provisions of this Annex.

2. Where the Members maintain a system of supervision over contracts of employment, such agreements shall indicate the methods by which the contractual obligations of the employer shall be enforced.

3. Such agreements shall provide, where appropriate, for co-operation between the competent authority of the territory of emigration or a body established in accordance with the terms of an international instrument and the competent authority of the territory of immigration, in respect of the assistance to be given to migrants concerning their conditions of employment in virtue of the provisions of Article 8.

\section{Article 13}

Any person who promotes clandestine or illegal immigration shall be subject to appropriate penalties. 


\section{ANNEX III \\ IMPORTATION OF THE PERSONAL EFFECTS, TOOLS AND EQUIPMENT OF MIGRANTS FOR EMPLOYMENT}

\section{Article 1}

1. Personal effects belonging to recruited migrants for employment and members of their families who have been authorised to accompany or join them shall be exempt from customs duties on arrival in the territory of immigration.

2. Portable hand-tools and portable equipment of the kind normally owned by workers for the carrying out of their particular trades belonging to recruited migrants for employment and members of their families who have been authorised to accompany or join them shall be exempt from customs duties on arrival in the territory of immigration if such tools and equipment can be shown at the time of importation to be in their actual ownership or possession, to have been in their possession and use for an appreciable time, and to be intended to be used by them in the course of their occupation.

\section{Article 2}

1. Personal effects belonging to migrants for employment and members of their families who have been authorised to accompany or join them shall be exempt from customs duties on the return of the said persons to their country of origin if such persons have retained the nationality of that country at the time of their return there.

2. Portable hand-tools and portable equipment of the kind normally owned by workers for the carrying out of their particular trades belonging to migrants for employment and members of their families who have been authorised to accompany or join them shall be exempt from customs duties on return of the said persons to their country of origin if such persons have retained the nationality of that country at the time of their return there and if such tools and equipment can be shown at the time of importation to be in their actual ownership or possession, to have been in their possession and use for an appreciable time, and to be intended to be used by them in the course of their occupation. 


\section{Migration for Employment Recommendation (Revised), 1949 (No. 86)}

The General Conference of the International Labour Organisation,

Having been convened at Geneva by the Governing Body of the International Labour Office, and having met its Thirty-second Session on 8 June 1949, and

Having decided upon the adoption of certain proposals with regard to the revision of the Migration for Employment Recommendation, 1939, and the Migration for Employment (Co-operation between States) Recommendation, 1939, adopted by the Conference at its Twenty-fifth Session, which are included in the eleventh item on the agenda of the session, and

Having determined that these proposals shall take the form of a Recommendation,

adopts this first day of July of the year one thousand nine hundred and forty-nine, the following Recommendation, which may be cited as the Migration for Employment Recommendation (Revised), 1949:

The Conference,

Having adopted the Migration for Employment Convention (Revised), 1949, and

Desiring to supplement its provisions by a Recommendation;

Recommends as follows:

1. For the purpose of this Recommendation -

(a) the term "migrant for employment" means a person who migrates from one country to another with a view to being employed otherwise than on his own account and includes any person regularly admitted as a migrant for employment;

(b) the term "recruitment" means -

(i) the engagement of a person in one territory on behalf of an employer in another territory, or

(ii) the giving of an undertaking to a person in one territory to provide him with employment in another territory, together with the making of any arrangements in connection with the operations mentioned in (i) and (ii) including the seeking for and selection of emigrants and the preparation for departure of the emigrants;

(c) the term introduction means any operations for ensuring or facilitating the arrival in or admission to a territory of persons who have been recruited within the meaning of subparagraph (b);

(d) the term placing means any operations for the purpose of ensuring or facilitating the employment of persons who have been introduced within the meaning of subparagraph (c).

2. For the purpose of this Recommendation, references to the Government or competent authority of a territory of emigration should be interpreted as referring, in the case of migrants who are refugees or displaced persons, to any body established in accordance with the terms of an international instrument which may be responsible for the protection of refugees and displaced persons who do not benefit from the protection of any Government. 
3. This Recommendation does not apply to -

(a) frontier workers;

(b) short-term entry of members of the liberal professions and artistes; and

(c) seamen.

\section{II}

4. (1) It should be the general policy of Members to develop and utilise all possibilities of employment and for this purpose to facilitate the international distribution of manpower and in particular the movement of manpower from countries which have a surplus of manpower to those countries that have a deficiency.

(2) The measures taken by each Member should have due regard to the manpower situation in the country and the Government should consult the appropriate organisations of employers and workers on all general questions concerning migration for employment.

\section{III}

5. (1) The free service provided in each country to assist migrants and their families and in particular to provide them with accurate information should be conducted -

(a) by public authorities; or

(b) by one or more voluntary organisations not conducted with a view to profit, approved for the purpose by the public authorities, and subject to the supervision of the said authorities; or

(c) partly by the public authorities and partly by one or more voluntary organisations fulfilling the conditions stated in subparagraph (b) of this Paragraph.

(2) The service should advise migrants and their families, in their languages or dialects or at least in a language which they can understand, on matters relating to emigration, immigration, employment and living conditions, including health conditions in the place of destination, return to the country of origin or of emigration, and generally speaking any other question which may be of interest to them in their capacity as migrants.

(3) The service should provide facilities for migrants and their families with regard to the fulfilment of administrative formalities and other steps to be taken in connection with the return of the migrants to the country of origin or of emigration, should the case arise.

(4) With a view to facilitating the adaptation of migrants, preparatory courses should, where necessary, be organised to inform the migrants of the general conditions and the methods of work prevailing in the country of immigration, and to instruct them in the language of that country. The countries of emigration and immigration should mutually agree to organise such courses.

6. On request information should be made available by Members to the International Labour Office and to other Members concerning their emigration laws and regulations, including administrative provisions relating to restrictions on emigration and facilities granted to emigrants, and appropriate details concerning the categories of persons wishing to emigrate.

7. On request information should be made available by Members to the International Labour Office and to other Members concerning their immigration laws and regulations, including administrative provisions, entry permits where needed, number and occupational qualifications of immigrants desired, laws and regulations affecting admission of migrants to employment, and any special facilities granted to migrants and measures to facilitate their adaptation to the economic and social organisation of the country of immigration. 
8. There should, as far as possible, be a reasonable interval between the publication and the coming into force of any measure altering the conditions on which emigration or immigration or the employment of migrants is permitted in order that these conditions may be notified in good time to persons who are preparing to emigrate.

9. Provision should be made for adequate publicity to be given at appropriate stages to the principal measures referred to in the preceding Paragraph, such publicity to be in the languages most commonly known to the migrants.

10. Migration should be facilitated by such measures as may be appropriate-

(a) to ensure that migrants for employment are provided in case of necessity with adequate accommodation, food and clothing on arrival in the country of immigration;

(b) to ensure, where necessary, vocational training so as to enable the migrants for employment to acquire the qualifications required in the country of immigration;

(c) to permit, taking into account the limits allowed by national laws and regulations concerning export and import of currency, the transfer of such part of the earnings and savings of migrants for employment as the migrants may desire;

(d) to arrange, in the case of permanent migration, for the transfer, where desired, to the country of immigration, of the capital of migrants for employment, within the limits allowed by national laws and regulations concerning export and import of currency;

(e) to provide access to schools for migrants and members of their families.

11. Migrants and the members of their families should be assisted in obtaining access to recreation and welfare facilities, and steps should be taken where necessary to ensure that special facilities are made available during the initial period of settlement in the country of immigration.

12. In the case of migrants under Government-sponsored arrangements for group transfer, medical assistance should be extended to such migrants in the same manner as provided for nationals.

\section{IV}

13. (1) Where necessary in the interest of the migrant, Members should require that any intermediary who undertakes the recruitment, introduction or placing of migrants for employment on behalf of an employer must obtain a written warrant from the employer, or some other document proving that he is acting on the employer's behalf.

(2) This document should be drawn up in, or translated into, the official language of the country of emigration and should set forth all necessary particulars concerning the employer, concerning the nature and scope of the recruitment, introduction or placing which the intermediary is to undertake, and concerning the employment offered, including the remuneration.

14. (1) The technical selection of migrants for employment should be carried out in such a way as to restrict migration as little as possible while ensuring that the migrants are qualified to perform the required work.

(2) Responsibility for such selection should be entrusted -

(a) to official bodies; or

(b) where appropriate, to private bodies of the territory of immigration duly authorised and, where necessary in the interest of the migrant, supervised by the competent authority of the territory of emigration. 
(3) The right to engage in selection should be subject to the prior authorisation of the competent authority of the territory where the said operation takes place, in such cases under such conditions as may be prescribed by the laws and regulations of that territory, or by agreement between the Government of the territory of emigration and the Government of the territory of immigration.

(4) As far as possible, intending migrants for employment should, before their departure from the territory of emigration, be examined for purposes of occupational and medical selection by a representative of the competent authority of the territory of immigration.

(5) If recruitment takes place on a sufficiently large scale there should be arrangements for close liaison and consultation between the competent authorities of the territories of emigration and immigration concerned.

(6) The operations referred to in the preceding subparagraphs of this Paragraph should be carried out as near as possible to the place where the intending migrant is recruited.

15. (1) Provision should be made by agreement for authorisation to be granted for a migrant for employment introduced on a permanent basis to be accompanied or joined by the members of his family.

(2) The movement of the members of the family of such a migrant authorised to accompany or join him should be specially facilitated by both the country of emigration and the country of immigration.

(3) For the purposes of this Paragraph, the members of the family of a migrant for employment should include his wife and minor children; favourable consideration should be given to requests for the inclusion of other members of the family dependent upon the migrant.

16. (1) Migrants for employment authorised to reside in a territory and the members of their families authorised to accompany or join them should as far as possible be admitted to employment in the same conditions as nationals.

(2) In countries in which the employment of migrants is subject to restrictions, these restrictions should as far as possible -

(a) cease to be applied to migrants who have regularly resided in the country for a period, the length of which should not, as a rule, exceed five years; and

(b) cease to be applied to the wife and children of an age to work who have been authorised to accompany or join the migrant, at the same time as they cease to be applied to the migrant.

17. In countries where the number of migrants for employment is sufficiently large, the conditions of employment of such workers should be specially supervised, such supervision being undertaken according to circumstances either by a special inspection service or by labour inspectors or other officials specialising in this work.

\section{VI}

18. (1) When a migrant for employment has been regularly admitted to the territory of a Member, the said Member should, as far as possible, refrain from removing such person or the members of his family from its territory on account of his lack of means or the state of the employment market, unless an agreement to this effect has been concluded between the competent authorities of the emigration and immigration territories concerned. 
(2) Any such agreement should provide -

(a) that the length of time the said migrant has been in the territory of immigration shall be taken into account and that in principle no migrant shall be removed who has been there for more than five years;

(b) that the migrant must have exhausted his rights to unemployment insurance benefit;

(c) that the migrant must have been given reasonable notice so as to give him time, more particularly to dispose of his property;

(d) that suitable arrangements shall have been made for his transport and that of the members of his family;

(e) that the necessary arrangements shall have been made to ensure that he and the members of his family are treated in a humane manner; and

(f) that the costs of the return of the migrant and the members of his family and of the transport of their household belongings to their final destination shall not fall on him.

19. Appropriate steps should be taken by the authorities of the territories concerned to consult the employers' and workers' organisations concerning the operations of recruitment, introduction and placing of migrants for employment.

\section{VII}

20. When migrants for employment or members of their families who have retained the nationality of their State of origin return there, that country should admit such persons to the benefit of any measures in force for the granting of poor relief and unemployment relief, and for promoting the re-employment of the unemployed, by exempting them from the obligation to comply with any condition as to previous residence or employment in the country or place.

\section{VIII}

21. (1) Members should in appropriate cases supplement the Migration for Employment Convention (Revised), 1949, and the preceding Paragraphs of the present Recommendation by bilateral agreements, which should specify the methods of applying the principles set forth in the Convention and in the Recommendation.

(2) In concluding such agreements, Members should take into account the provisions of the Model Agreement annexed to the present Recommendation in framing appropriate clauses for the organisation of migration for employment and the regulation of the conditions of transfer and employment of migrants, including refugees and displaced persons.

\section{ANNEX}

\section{MODEL AGREEMENT ON TEMPORARY AND PERMANENT MIGRATION FOR EMPLOYMENT, INCLUDING MIGRATION OF REFUGEES AND DISPLACED PERSONS ${ }^{1}$}

\section{ARTICLE 1. EXCHANGE OF INFORMATION}

1. The competent authority of the territory of immigration shall periodically furnish appropriate information to the competent authority of the territory of emigration or in the

\footnotetext{
1 The phrases and passages in italics refer primarily to permanent migration; those enclosed within square brackets refer solely to migration of refugees and displaced persons.
} 
case of refugees and displaced persons, to any body established in accordance with the terms of an international instrument which may be responsible for the protection of refugees and displaced persons who do not benefit from the protection of any Government concerning:

(a) legislative and administrative provisions relating to entry, employment, residence and settlement of migrants and of their families;

(b) the number, the categories and the occupational qualifications of the migrants desired;

(c) the conditions of life and work for the migrants and, in particular, cost of living and minimum wages according to occupational categories and regions of employment, supplementary allowances, if any, nature of employments available, bonus on engagement, if any, social security systems and medical assistance, provisions concerning transport of migrants and of their tools and belongings, housing conditions and provisions for the supply of food and clothing, measures relating to the transfer of the migrants' savings and other sums due in virtue of this Agreement;

(d) special facilities, if any, for migrants;

(e) facilities for general education and vocational training for migrants;

(f) measures designed to promote rapid adaptation of migrants;

(g) procedure and formalities required for naturalisation.

2. The competent authority of the territory of emigration or in the case of refugees and displaced persons, any body established in accordance with the terms of an international instrument which may be responsible for the protection of refugees and displaced persons who do not benefit from the protection of any Government shall bring this information to the attention of persons or bodies interested.

3. The competent authority of the territory of emigration or in the case of refugees and displaced persons, any body established in accordance with the terms of an international instrument which may be responsible for the protection of refugees and displaced persons who do not benefit from the protection of any Government shall periodically furnish appropriate information to the competent authority of the territory of immigration concerning -

(a) legislative and administrative provisions relating to emigration;

(b) the number and occupational qualifications of intending emigrants, as well as the composition of their families;

(c) the social security system;

(d) special facilities, if any, for migrants;

(e) the environment and living conditions to which migrants are accustomed;

(f) the provisions in force regarding the export of capital.

4. The competent authority of the territory of immigration shall bring this information to the attention of persons or bodies interested.

5. The information mentioned in paragraphs 1 to 4 above shall also be transmitted by the respective parties to the International Labour Office.

\section{ARTICLE 2. ACTION AGAINST MISLEADING PROPAGANDA}

1. The parties agree, with regard to their respective territories, to take all practical steps, so far as national laws and regulations permit, against misleading propaganda relating to emigration and immigration. 
2. For this purpose the parties will, where appropriate, act in co-operation with the competent authorities of other countries concerned.

\section{ARTICLE 3. ADMINISTRATIVE FORMALITIES}

The parties agree to take measures with a view to accelerating and simplifying the carrying out of administrative formalities relating to departure, travel, entry, residence, and settlement of migrants and as far as possible for the members of their families. Such measures shall include the provision of an interpretation service, where necessary.

\section{ARTICLE 4. VALIDITY OF DOCUMENTS}

1. The parties shall determine the conditions to be met for purposes of recognition in the territory of immigration of any document issued by the competent authority of the territory of emigration in respect of migrants and members of their families [or in the case of refugees and displaced persons, by any body established in accordance with the terms of an international instrument which may be responsible for the protection of refugees and displaced persons who do not benefit from the protection of any Government] concerning -

(a) civil status;

(b) legal status;

(c) occupational qualifications;

(d) general education and vocational training; and

(e) participation in social security systems.

2. The parties shall also determine the application of such recognition.

[3. In the case of refugees and displaced persons, the competent authority of the territory of immigration shall recognise the validity of any travel document issued in lieu of a national passport by the competent authority of the territory of emigration and, in particular, of travel documents issued in accordance with the terms of an international Agreement (e.g. the travel document established by the Agreement of 15 October 1946, and the Nansen passport).]

\section{ARTICLE 5. CONDITIONS AND CRITERIA OF MIGRATION}

1. The parties shall jointly determine -

(a) the requirements for migrants and members of their families, as to age, physical aptitude and health, as well as the occupational qualifications for the various branches of economic activity and for the various occupational categories;

(b) the categories of the members of the migrants' families authorised to accompany or to join them.

2. The parties shall also determine, in accordance with the provisions of Article 28 of this Agreement -

(a) the numbers and occupational categories of migrants to be recruited in the course of a stated period;

(b) the areas of recruitment and the areas of placing and settlement [except that in the case of refugees and displaced persons the determination of the areas of recruitment shall be reserved to any body established in accordance with the terms of an international instrument which may be responsible for the protection of refugees and displaced persons who do not benefit from the protection of any Government]. 
3. In order to recruit migrants required to meet the technical needs of the territory of immigration and who can adapt themselves easily to the conditions in the territory of immigration, the parties shall determine criteria to govern technical selection of the migrants.

4. In drawing up these criteria, the two parties shall take into consideration -

(a) with respect to medical selection:

(i) the nature of the medical examination which migrants shall undergo (general medical examination, X-ray examination, laboratory examination, etc.);

(ii) the drawing up of lists of diseases and physical defects which clearly constitute a disability for employment in certain occupations;

(iii) minimum health provisions prescribed by international health conventions and relating to movement of population from one country to another;

(b) with respect to vocational selection:

(i) qualifications required of migrants with respect to each occupation or groups of occupations;

(ii) enumeration of alternative occupations requiring similar qualifications or capacities on the part of the workers in order to fulfil the needs of specified occupations for which it is difficult to recruit a sufficient number of qualified workers;

(iii) development of psycho-technical testing;

(c) with respect to selection based on the age of migrants, flexibility to be given to the application of age criteria in order to take into consideration on the one hand the requirements of various occupations and, on the other, the varying capacities of different individuals at a given age.

\section{ARTICLE 6. ORGANISATION OF RECRUITMENT, INTRODUCTION AND PLACING}

1. The bodies or persons which engage in the operations of recruitment, introduction and placing of migrants and of members of their families shall be named by the competent authorities of the respective territories [or in the case of refugees and displaced persons, by any body established in accordance with the terms of an international instrument which may be responsible for the protection of refugees and displaced persons who do not benefit from the protection of any Government on the one hand and the competent authority of the territory of immigration on the other] subject to the approval of both parties.

2. Subject to the provisions of the following paragraphs, the right to engage in the operations of recruitment, introduction and placing shall be restricted to -

(a) public employment offices or other public bodies of the territory in which the operations take place;

(b) public bodies of a territory other than that in which the operations take place which are authorised to operate in that territory by an agreement between the parties;

(c) any body established in accordance with the terms of an international instrument.

3. In addition, in so far as the national laws and regulations of the parties permit and subject to the approval and supervision of the competent authorities of the parties, the operations of recruitment, introduction and placing may be undertaken by -

(a) the prospective employer or a person in his service acting on his behalf; and

(b) private agencies. 
4. The administrative costs of recruitment, introduction and placing shall not be borne by the migrants.

\section{ARTICLE 7. SELECTION TESTING}

1. An intending migrant shall undergo an appropriate examination in the territory of emigration; any such examination should inconvenience him as little as possible.

2. With respect to the organisation of the selection of migrants, the parties shall agree on -

(a) recognition and composition of official agencies or private bodies authorised by the competent authority of the territory of immigration to carry out selection operations in the territory of emigration;

(b) organisation of selection examinations, the centres where they are to be carried out, and allocation of expenses resulting from these examinations;

(c) co-operation of the competent authorities of the two parties and in particular of their employment services in organising selection.

\section{ARTICLE 8. INFORMATION AND ASSISTANCE OF MIGRANTS}

1. The migrant accepted after medical and occupational examination in the assembly or selection centre shall receive, in a language that he understands, all information he may still require as to the nature of the work for which he has been engaged, the region of employment, the undertaking to which he is assigned, travel arrangements and the conditions of life and work including health and related matters in the country and region to which he is going.

2. On arrival in the country of destination, and at a reception centre if such exists, or at the place of residence, migrants and the members of their families shall receive all the documents which they need for their work, their residence and their settlement in the country, as well as information, instruction and advice regarding conditions of life and work, and any other assistance that they may need to adapt themselves to the conditions in the country of immigration.

\section{ARTICLE 9. EDUCATION AND VOCATIONAL TRAINING}

The parties shall co-ordinate their activities concerning the organisation of educational courses for migrants, which shall include general information on the country of immigration, instruction in the language of that country, and vocational training.

\section{ARTICLE 10. EXCHANGE OF TRAINEES}

The parties agree to further the exchange of trainees, and to determine in a separate agreement the conditions governing such exchanges.

\section{ARTICLE 11. CONDITIONS OF TRANSPORT}

1. During the journey from their place of residence to the assembly or selection centre, as well as during their stay in the said centre, migrants and the members of their families shall receive from the competent authority of the territory of immigration [or in the case of refugees and displaced persons, from any body established in accordance with the terms of an international instrument which may be responsible for the protection of refugees and displaced persons who do not benefit from the protection of any Government] any assistance which they may require. 
2. The competent authorities of the territories of emigration and immigration shall, each within its own jurisdiction, safeguard the health and welfare of, and render assistance to, migrants and the members of their families during the journey from the assembly or selection centre to the place of their employment, as well as during their stay in a reception centre if such exists.

3. Migrants and members of their families shall be transported in a manner appropriate for human beings and in conformity with the laws and regulations in force.

4. The parties shall agree upon the terms and conditions for the application of the provisions of this Article.

\section{ARTICLE 12. TRAVEL AND MAINTENANCE EXPENSES}

The parties shall agree upon the methods for meeting the cost of travel of the migrants and the members of their families from the place of their residence to the place of their destination, and the cost of their maintenance while travelling, sick or hospitalised, as well as the cost of transport of their personal belongings.

\section{ARTICLE 13. TRANSFER OF FUNDS}

1. The competent authority of the territory of emigration shall, as far as possible and in conformity with national laws and regulations concerning the import and export of foreign currency, authorise and provide facilities for migrants and for members of their families to withdraw from their country such sums as they may need for their initial settlement abroad.

2. The competent authority of the territory of immigration shall, as far as possible and in conformity with national laws and regulations concerning the import and export of foreign currency, authorise and provide facilities for the periodical transfer to the territory of emigration of migrants' savings and of any other sums due in virtue of this Agreement.

3. The transfers of funds mentioned in paragraphs 1 and 2 above shall be made at the prevailing official rate of exchange.

4. The parties shall take all measures necessary for the simplification and acceleration of administrative formalities regarding the transfer of funds so that such funds may be available with the least possible delay to those entitled to them.

5. The parties shall determine if and under what conditions a migrant may be required to remit part of his wages for the maintenance of his family remaining in his country or in the territory from which he emigrated.

\section{ARTICLE 14. ADAPTATION AND NATURALISATION}

The competent authority of the territory of immigration shall take measures to facilitate adaptation to national climatic, economic and social conditions and facilitate the procedure of naturalisation of migrants and of members of their families.

\section{ARTICLE 15. SUPERVISION OF LIVING AND WORKING CONDITIONS}

1. Provision shall be made for the supervision by the competent authority or duly authorised bodies of the territory of immigration of the living and working conditions, including hygienic conditions, to which the migrants are subject.

2. With respect to temporary migrants, the parties shall provide, where appropriate, for authorised representatives of the territory of emigration [or in the case of refugees and displaced persons, of any body established in accordance with the terms of an international instrument which may be responsible for the protection of refugees and displaced persons 
who do not benefit from the protection of any Government] to co-operate with the competent authority or duly authorised bodies of the territory of immigration in carrying out this supervision.

3. During a fixed period, the duration of which shall be determined by the parties, migrants shall receive special assistance in regard to matters concerning their conditions of employment.

4. Assistance with respect to the employment and living conditions of the migrants may be given either through the regular labour inspection service of the territory of immigration or through a special service for migrants, in co-operation where appropriate with approved voluntary organisations.

5. Provision shall be made where appropriate for the co-operation of representatives of the territory of emigration [or in the case of refugees and displaced persons, of any body established in accordance with the terms of an international instrument which may be responsible for the protection of refugees and displaced persons who do not benefit from the protection of any Government] with such services.

\section{ARTICLE 16. SETTLEMENT OF DISPUTES}

1. In case of a dispute between a migrant and his employer, the migrant shall have access to the appropriate courts or shall otherwise obtain redress for his grievances, in accordance with the laws and regulations of the territory of immigration.

2. The authorities shall establish such other machinery as is necessary to settle disputes arising out of the Agreement.

\section{ARTICLE 17. EQUALITY OF TREATMENT}

1. The competent authority of the territory of immigration shall grant to migrants and to members of their families with respect to employment in which they are eligible to engage treatment no less favourable than that applicable to its won nationals in virtue of legal or administrative provisions or collective labour agreements.

2. Such equality of treatment shall apply, without discrimination in respect of nationality, race, religion or sex, to immigrants lawfully within the territory of immigration in respect of the following matters:

(a) in so far as such matters are regulated by laws or regulations or are subject to the control of administrative authorities,

(i) remuneration, including family allowances where these form part of remuneration, hours of work, weekly rest days, overtime arrangements, holidays with pay and other regulations concerning employment, including limitations on home work, minimum age provisions, women's work, and the work of young persons;

(ii) membership of trade unions and enjoyment of the benefits of collective bargaining;

(iii) admission to schools, to apprenticeship and to courses or schools for vocational or technical training, provided that this does not prejudice nationals of the country of immigration;

(iv) recreation and welfare measures;

(b) employment taxes, dues or contributions payable in respect of the persons employed;

(c) hygiene, safety and medical assistance;

(d) legal proceedings relating to the matters referred to in this Agreement. 


\section{ARTICLE 18. ACCESS TO TRADES AND OCCUPATIONS AND THE RIGHT TO ACQUIRE PROPERTY}

Equality of treatment shall also apply to-

(a) access to trades and occupations to the extent permitted under national laws and regulations;

(b) acquisition, possession and transmission of urban or rural property.

\section{ARTICLE 19. SUPPLY OF FOOD}

The treatment applied to migrants and the members of their families shall be the same as that applied to national workers in the same occupation as regards the supply of food.

\section{ARTICLE 20. HOUSING CONDITIONS}

The competent authority of the territory of immigration shall ensure that migrants and the members of their families have hygienic and suitable housing, in so far as the necessary housing is available.

\section{ARTICLE 21. SOCIAL SECURITY}

1. The two parties shall determine in a separate agreement the methods of applying a system of social security to migrants and their dependants.

2. Such agreement shall provide that the competent authority of the territory of immigration shall take measures to ensure to the migrants and their dependants treatment not less favourable than that afforded by it to its nationals, except where particular residence qualifications apply to nationals.

3. The agreement shall embody appropriate arrangements for the maintenance of migrants' acquired rights and rights in course of acquisition framed with due regard to the principles of the Maintenance of Migrants' Pension Rights Convention, 1935, or of any revision of that Convention.

4. The agreement shall provide that the competent authority of the territory of immigration shall take measures to grant to temporary migrants and their dependants treatment not less favourable than that afforded by it to its nationals, subject in the case of compulsory pension schemes to appropriate arrangements being made for the maintenance of migrants' acquired rights and rights in course of acquisition.

\section{ARTICLE 22. CONTRACTS OF EMPLOYMENT}

1. In countries where a system of model contracts is used, the individual contract of employment for migrants shall be based on a model contract drawn up by the parties for the principal branches of economic activity.

2. The individual contract of employment shall set forth the general conditions of engagement and of employment provided in the relevant model contract and shall be translated into a language which the migrant understands. A copy of the contract shall be delivered to the migrant before departure from the territory of emigration or, if it is agreed between the two parties concerned, in a reception centre on arrival in the territory of immigration. In the latter case before departure the migrant shall be informed in writing by a document which relates either to him individually or to a group of migrants of which he is a member, of the occupational category in which he is to be engaged and the other conditions of work, in particular the minimum wage which is guaranteed to him. 
3. The individual contract of employment shall contain necessary information, such as: -

(a) the full name of the worker as well as the date and place of birth, his family status, his place of residence and of recruitment;

(b) the nature of the work, and the place where it is to be performed;

(c) the occupational category in which he is placed;

(d) remuneration for ordinary hours of work, overtime, night work and holidays, and the medium for wage payment;

(e) bonuses, indemnities and allowances, if any;

(f) conditions under which and extent to which the employer may be authorised to make any deductions from remuneration;

(g) conditions regarding food if food is to be provided by the employer;

(h) the duration of the contract as well as the conditions of renewal and denunciation of the contract;

(i) the conditions under which entry and residence in the territory of immigration are permitted;

(j) the method of meeting the expenses of the journey of the migrant and the members of his family;

(k) in case of temporary migration, the method of meeting the expenses of return to the home country or the territory of migration, as appropriate;

(1) the grounds on which a contract may be prematurely terminated.

\section{ARTICLE 23. CHANGE OF EMPLOYMENT}

1. If the competent authority of the territory of immigration considers that the employment for which the migrant has been recruited does not correspond to his physical capacity or occupational qualifications, the said authority shall provide facilities for placing the said migrant in an employment corresponding to his capacity or qualifications, and in which he may be employed in accordance with national laws or regulations.

2. During periods of unemployment, if any, the method of maintaining the migrant and the dependent members of his family authorised to accompany or join him shall be determined by arrangements made under a separate agreement.

\section{ARTICLE 24. EMPLOYMENT STABILITY}

1. If before the expiration of the period of his contract the migrant for employment becomes redundant in the undertaking or branch of economic activity for which he was engaged, the competent authority of the territory of immigration shall, subject to the provisions of the contract, facilitate the placing of the said migrant in other suitable employment in which he may be employed in accordance with national laws or regulations.

2. If the migrant is not entitled to benefits under an unemployment insurance or assistance scheme, his maintenance, as well as that of dependent members of his family during any period in which he is unemployed shall be determined by a separate agreement in so far as this is not inconsistent with the terms of his contract.

3. The provisions of this Article shall not affect the right of the migrant to benefit from any provisions that may be included in his contract in case it is prematurely terminated by the employer. 


\section{ARTICLE 25. PROVISIONS CONCERNING COMPULSORY RETURN}

1. The competent authority of the territory of immigration undertakes that a migrant and the members of his family who have been authorised to accompany or join him will not be returned to the territory from which he emigrated unless he so desires if, because of illness or injury, he is unable to follow his occupation.

2. The Government of the territory of immigration undertakes not to send refugees and displaced persons or migrants who do not wish to return to their country of origin for political reasons back to their territory of origin as distinct from the territory from which they were recruited, unless they formally express this desire by a request in writing addressed both to the competent authority of the territory of immigration and the representative of the body set up in accordance with the provisions of an international instrument which may be responsible for the protection of refugees and displaced persons who do not benefit from the protection of any Government.

\section{ARTICLE 26. RETURN JOURNEY}

1. The cost of the return journey of a migrant introduced under a plan sponsored by the Government of the territory of immigration, who is obliged to leave his employment for reasons for which he is not responsible, and who cannot, in virtue of national laws and regulations, be placed in an employment for which he is eligible, shall be regulated as follows:

(a) the cost of the return journey of the migrant, and persons dependent upon him, shall in no case fall on the migrant himself;

(b) supplementary bilateral agreements shall specify the method of meeting the cost of this return journey;

(c) in any case, even if no provision to this effect is included in a bilateral agreement, the information given to migrants at the time of their recruitment shall specify what person or agency is responsible for defraying the cost of return in the circumstances mentioned in this Article.

2. In accordance with the methods of co-operation and consultation agreed upon under Article 28 of this Agreement, the two parties shall determine the measures necessary to organise the return home of the said persons and to assure to them in the course of the journey the conditions of health and welfare and the assistance which they enjoyed during the outward journey.

3. The competent authority of the territory of emigration shall exempt from customs duties on their arrival -

(a) personal effects; and

(b) portable hand-tools and portable equipment of the kind normally owned by workers for the carrying out of their particular trades, which have been in possession and use of the said persons for an appreciable time and which are intended to be used by them in the course of their occupation.

\section{ARTICLE 27. DOUBLE TAXATION}

The two parties shall determine in a separate agreement the measures to be taken to avoid double taxation on the earnings of a migrant for employment. 


\section{ARTICLE 28. METHODS OF CO-OPERATION}

1. The two parties shall agree on the methods of consultation and co-operation necessary to carry out the terms of the Agreement.

2. When so requested by the representatives of the two parties the International Labour Office shall be associated with such consultation and co-operation.

\section{ARTICLE 29. FINAL PROVISIONS}

1. The parties shall determine the duration of the Agreement as well as the period of notice for termination.

2. The parties shall determine those provisions of this Agreement which shall remain in operation after expiration of this Agreement. 


\section{Migrant Workers (Supplementary Provisions) Convention, 1975 (No. 143)}

The General Conference of the International Labour Organisation,

Having been convened at Geneva by the Governing Body of the International Labour Office, and having met in its Sixtieth Session on 4 June 1975, and

Considering that the Preamble of the Constitution of the International Labour Organisation assigns to it the task of protecting "the interests of workers when employed in countries other than their own", and

Considering that the Declaration of Philadelphia reaffirms, among the principles on which the Organisation is based, that "labour is not a commodity", and that "poverty anywhere constitutes a danger to prosperity everywhere", and recognises the solemn obligation of the ILO to further programmes which will achieve in particular full employment through "the transfer of labour, including for employment ...",

Considering the ILO World Employment Programme and the Employment Policy Convention and Recommendation, 1964, and emphasising the need to avoid the excessive and uncontrolled or unassisted increase of migratory movements because of their negative social and human consequences, and

Considering that in order to overcome underdevelopment and structural and chronic unemployment, the governments of many countries increasingly stress the desirability of encouraging the transfer of capital and technology rather than the transfer of workers in accordance with the needs and requests of these countries in the reciprocal interest of the countries of origin and the countries of employment, and

Considering the right of everyone to leave any country, including his own, and to enter his own country, as set forth in the Universal Declaration of Human Rights and the International Covenant on Civil and Political Rights, and

Recalling the provisions contained in the Migration for Employment Convention and Recommendation (Revised), 1949, in the Protection of Migrant Workers (Underdeveloped Countries) Recommendation, 1955, in the Employment Policy Convention and Recommendation, 1964, in the Employment Service Convention and Recommendation, 1948, and in the Fee-Charging Employment Agencies Convention (Revised), 1949, which deal with such matters as the regulation of the recruitment, introduction and placing of migrant workers, the provision of accurate information relating to migration, the minimum conditions to be enjoyed by migrants in transit and on arrival, the adoption of an active employment policy and international collaboration in these matters, and

Considering that the emigration of workers due to conditions in labour markets should take place under the responsibility of official agencies for employment or in accordance with the relevant bilateral or multilateral agreements, in particular those permitting free circulation of workers, and

Considering that evidence of the existence of illicit and clandestine trafficking in labour calls for further standards specifically aimed at eliminating these abuses, and

Recalling the provisions of the Migration for Employment Convention (Revised), 1949, which require ratifying Members to apply to immigrants lawfully within their territory treatment not less favourable than that which they apply to their nationals in respect of a variety of matters which it enumerates, in so far as these are 
regulated by laws or regulations or subject to the control of administrative authorities, and

Recalling that the definition of the term "discrimination" in the Discrimination (Employment and Occupation) Convention, 1958, does not mandatorily include distinctions on the basis of nationality, and

Considering that further standards, covering also social security, are desirable in order to promote equality of opportunity and treatment of migrant workers and, with regard to matters regulated by laws or regulations or subject to the control of administrative authorities, ensure treatment at least equal to that of nationals, and

Noting that, for the full success of action regarding the very varied problems of migrant workers, it is essential that there be close co-operation with the United Nations and other specialised agencies, and

Noting that, in the framing of the following standards, account has been taken of the work of the United Nations and of other specialised agencies and that, with a view to avoiding duplication and to ensuring appropriate co-ordination, there will be continuing co-operation in promoting and securing the application of the standards, and

Having decided upon the adoption of certain proposals with regard to migrant workers, which is the fifth item on the agenda of the session, and

Having determined that these proposals shall take the form of an international Convention supplementing the Migration for Employment Convention (Revised), 1949, and the Discrimination (Employment and Occupation) Convention, 1958,

adopts this twenty-fourth day of June of the year one thousand nine hundred and seventyfive the following Convention, which may be cited as the Migrant Workers (Supplementary Provisions) Convention, 1975:

\section{PART I. MIGRATIONS IN ABUSIVE CONDITIONS}

\section{Article 1}

Each Member for which this Convention is in force undertakes to respect the basic human rights of all migrant workers.

\section{Article 2}

1. Each Member for which this Convention is in force shall systematically seek to determine whether there are illegally employed migrant workers on its territory and whether there depart from, pass through or arrive in its territory any movements of migrants for employment in which the migrants are subjected during their journey, on arrival or during their period of residence and employment to conditions contravening relevant international multilateral or bilateral instruments or agreements, or national laws or regulations.

2. The representative organisations of employers and workers shall be fully consulted and enabled to furnish any information in their possession on this subject.

\section{Article 3}

Each Member shall adopt all necessary and appropriate measures, both within its jurisdiction and in collaboration with other Members -

(a) to suppress clandestine movements of migrants for employment and illegal employment of migrants, and 
(b) against the organisers of illicit or clandestine movements of migrants for employment departing from, passing through or arriving in its territory, and against those who employ workers who have immigrated in illegal conditions, in order to prevent and to eliminate the abuses referred to in Article 2 of this Convention.

\section{Article 4}

In particular, Members shall take such measures as are necessary, at the national and the international level, for systematic contact and exchange of information on the subject with other States, in consultation with representative organisations of employers and workers.

\section{Article 5}

One of the purposes of the measures taken under Articles 3 and 4 of this Convention shall be that the authors of manpower trafficking can be prosecuted whatever the country from which they exercise their activities.

\section{Article 6}

1. Provision shall be made under national laws or regulations for the effective detection of the illegal employment of migrant workers and for the definition and the application of administrative, civil and penal sanctions, which include imprisonment in their range, in respect of the illegal employment of migrant workers, in respect of the organisation of movements of migrants for employment defined as involving the abuses referred to in Article 2 of this Convention, and in respect of knowing assistance to such movements, whether for profit or otherwise.

2. Where an employer is prosecuted by virtue of the provision made in pursuance of this Article, he shall have the right to furnish proof of his good faith.

\section{Article 7}

The representative organisations of employers and workers shall be consulted in regard to the laws and regulations and other measures provided for in this Convention and designed to prevent and eliminate the abuses referred to above, and the possibility of their taking initiatives for this purpose shall be recognised.

\section{Article 8}

1. On condition that he has resided legally in the territory for the purpose of employment, the migrant worker shall not be regarded as in an illegal or irregular situation by the mere fact of the loss of his employment, which shall not in itself imply the withdrawal of his authorisation of residence or, as the case may be, work permit.

2. Accordingly, he shall enjoy equality of treatment with nationals in respect in particular of guarantees of security of employment, the provision of alternative employment, relief work and retraining.

\section{Article 9}

1. Without prejudice to measures designed to control movements of migrants for employment by ensuring that migrant workers enter national territory and are admitted to employment in conformity with the relevant laws and regulations, the migrant worker shall, in cases in which these laws and regulations have not been respected and in which his position cannot be regularised, enjoy equality of treatment for himself and his family in 
respect of rights arising out of past employment as regards remuneration, social security and other benefits.

2. In case of dispute about the rights referred to in the preceding paragraph, the worker shall have the possibility of presenting his case to a competent body, either himself or through a representative.

3. In case of expulsion of the worker or his family, the cost shall not be borne by them.

4. Nothing in this Convention shall prevent Members from giving persons who are illegally residing or working within the country the right to stay and to take up legal employment.

\section{PART II. EQUALITY OF OPPORTUNITY AND TREATMENT}

\section{Article 10}

Each Member for which the Convention is in force undertakes to declare and pursue a national policy designed to promote and to guarantee, by methods appropriate to national conditions and practice, equality of opportunity and treatment in respect of employment and occupation, of social security, of trade union and cultural rights and of individual and collective freedoms for persons who as migrant workers or as members of their families are lawfully within its territory.

\section{Article 11}

1. For the purpose of this Part of this Convention, the term "migrant worker" means a person who migrates or who has migrated from one country to another with a view to being employed otherwise than on his own account and includes any person regularly admitted as a migrant worker.

2. This Part of this Convention does not apply to -

(a) frontier workers;

(b) artistes and members of the liberal professions who have entered the country on a shortterm basis;

(c) seamen;

(d) persons coming specifically for purposes of training or education;

(e) employees of organisations or undertakings operating within the territory of a country who have been admitted temporarily to that country at the request of their employer to undertake specific duties or assignments, for a limited and defined period of time, and who are required to leave that country on the completion of their duties or assignments.

\section{Article 12}

Each Member shall, by methods appropriate to national conditions and practice -

(a) seek the co-operation of employers' and workers' organisations and other appropriate bodies in promoting the acceptance and observance of the policy provided for in Article 10 of this Convention;

(b) enact such legislation and promote such educational programmes as may be calculated to secure the acceptance and observance of the policy;

(c) take measures, encourage educational programmes and develop other activities aimed at acquainting migrant workers as fully as possible with the policy, with their rights and 
obligations and with activities designed to give effective assistance to migrant workers in the exercise of their rights and for their protection;

(d) repeal any statutory provisions and modify any administrative instructions or practices which are inconsistent with the policy;

(e) in consultation with representative organisations of employers and workers, formulate and apply a social policy appropriate to national conditions and practice which enables migrant workers and their families to share in advantages enjoyed by its nationals while taking account, without adversely affecting the principle of equality of opportunity and treatment, of such special needs as they may have until they are adapted to the society of the country of employment;

(f) take all steps to assist and encourage the efforts of migrant workers and their families to preserve their national and ethnic identity and their cultural ties with their country of origin, including the possibility for children to be given some knowledge of their mother tongue;

(g) guarantee equality of treatment, with regard to working conditions, for all migrant workers who perform the same activity whatever might be the particular conditions of their employment.

\section{Article 13}

1. A Member may take all necessary measures which fall within its competence and collaborate with other Members to facilitate the reunification of the families of all migrant workers legally residing in its territory.

2. The members of the family of the migrant worker to which this Article applies are the spouse and dependent children, father and mother.

\section{Article 14}

A Member may -

(a) make the free choice of employment, while assuring migrant workers the right to geographical mobility, subject to the conditions that the migrant worker has resided lawfully in its territory for the purpose of employment for a prescribed period not exceeding two years or, if its laws or regulations provide for contracts for a fixed term of less than two years, that the worker has completed his first work contract;

(b) after appropriate consultation with the representative organisations of employers and workers, make regulations concerning recognition of occupational qualifications acquired outside its territory, including certificates and diplomas;

(c) restrict access to limited categories of employment or functions where this is necessary in the interests of the State.

\section{PART III. FINAL PROVISIONS}

\section{Article 15}

This Convention does not prevent Members from concluding multilateral or bilateral agreements with a view to resolving problems arising from its application.

\section{Article 16}

1. Any Member which ratifies this Convention may, by a declaration appended to its ratification, exclude either Part I or Part II from its acceptance of the Convention. 
2. Any Member which has made such a declaration may at any time cancel that declaration by a subsequent declaration.

3. Every Member for which a declaration made under paragraph 1 of this Article is in force shall indicate in its reports upon the application of this Convention the position of its law and practice in regard to the provisions of the Part excluded from its acceptance, the extent to which effect has been given, or is proposed to be given, to the said provision and the reasons for which it has not yet included them in its acceptance of the Convention.

\section{Article 17}

The formal ratifications of this Convention shall be communicated to the DirectorGeneral of the International Labour Office for registration.

\section{Article 18}

1. This Convention shall be binding only upon those Members of the International Labour Organisation whose ratifications have been registered with the Director-General.

2. It shall come into force twelve months after the date on which the ratifications of two Members have been registered with the Director-General.

3. Thereafter, this Convention shall come into force for any Member twelve months after the date on which its ratification has been registered.

\section{Article 19}

1. A Member which has ratified this Convention may denounce it after the expiration of ten years from the date on which the Convention first comes into force, by an act communicated to the Director-General of the International Labour Office for registration. Such denunciation shall not take effect until one year after the date on which it is registered.

2. Each Member which has ratified this Convention and which does not, within the year following the expiration of the period of ten years mentioned in the preceding paragraph, exercise the right of denunciation provided for in this Article, will be bound for another period of ten years and, thereafter, may denounce this Convention at the expiration of each period of ten years under the terms provided for in this Article.

\section{Article 20}

1. The Director-General of the International Labour Office shall notify all Members of the International Labour Organisation of the registration of all ratifications and denunciations communicated to him by the Members of the Organisation.

2. When notifying the Members of the Organisation of the registration of the second ratification communicated to him, the Director-General shall draw the attention of the Members of the Organisation to the date upon which the Convention will come into force.

\section{Article 21}

The Director-General of the International Labour Office shall communicate to the Secretary-General of the United Nations for registration in accordance with Article 102 of the Charter of the United Nations full particulars of all ratifications and acts of denunciation registered by him in accordance with the provisions of the preceding Articles. 


\section{Article 22}

At such times as it may consider necessary the Governing Body of the International Labour Office shall present to the General Conference a report on the working of this Convention and shall examine the desirability of placing on the agenda of the Conference the question of its revision in whole or in part.

\section{Article 23}

1. Should the Conference adopt a new Convention revising this Convention in whole or in part, then, unless the new Convention otherwise provides -

(a) the ratification by a Member of the new revising Convention shall ipso jure involve the immediate denunciation of this Convention, notwithstanding the provisions of Article 19 above, if and when the new revising Convention shall have come into force;

(b) as from the date when the new revising Convention comes into force this Convention shall cease to be open to ratification by the Members.

2. This Convention shall in any case remain in force in its actual form and content for those Members which have ratified it but have not ratified the revising Convention.

Article 24

The English and French versions of the text of this Convention are equally authoritative. 


\section{Migrant Workers Recommendation, 1975 (No. 151)}

The General Conference of the International Labour Organisation,

Having been convened at Geneva by the Governing Body of the International Labour Office, and having met in its Sixtieth Session on 4 June 1975, and

Considering that the Preamble of the Constitution of the International Labour Organisation assigns to it the task of protecting "the interests of workers when employed in countries other than their own", and

Recalling the provisions contained in the Migration for Employment Convention and Recommendation (Revised), 1949, and in the Protection of Migrant Workers (Underdeveloped Countries) Recommendation, 1955, which deal with such matters as the preparation and organisation of migration, social services to be provided to migrant workers and their families, in particular before their departure and during their journey, equality of treatment as regards a variety of matters which they enumerate, and the regulation of the stay and return of migrant workers and their families, and

Having adopted the Migrant Workers (Supplementary Provisions) Convention, 1975, and

Considering that further standards are desirable as regards equality of opportunity and treatment, social policy in regard to migrants and employment and residence, and

Having decided upon the adoption of certain proposals with regard to migrant workers, which is the fifth item on the agenda of the session, and

Having determined that these proposals shall take the form of a Recommendation,

adopts this twenty-fourth day of June of the year one thousand nine hundred and seventyfive the following Recommendation, which may be cited as the Migrant Workers Recommendation, 1975:

1. Members should apply the provision of this Recommendation within the framework of a coherent policy on international migration for employment. That policy should be based upon the economic and social needs of both countries of origin and countries of employment; it should take account not only of short-term manpower needs and resources but also of the long-term social and economic consequences of migration for migrants as well as for the communities concerned.

\section{EQUALITY OF OPPORTUNITY AND TREATMENT}

2. Migrant workers and members of their families lawfully within the territory of a Member should enjoy effective equality of opportunity and treatment with nationals of the Member concerned in respect of -

(a) access to vocational guidance and placement services;

(b) access to vocational training and employment of their own choice on the basis of individual suitability for such training or employment, account being taken of qualifications acquired outside the territory of and in the country of employment;

(c) advancement in accordance with their individual character, experience, ability and diligence;

(d) security of employment, the provision of alternative employment, relief work and retraining; 
(e) remuneration for work of equal value;

(f) conditions of work, including hours of work, rest periods, annual holidays with pay, occupational safety and occupational health measures, as well as social security measures and welfare facilities and benefits provided in connection with employment;

(g) membership of trade unions, exercise of trade union rights and eligibility for office in trade unions and in labour-management relations bodies, including bodies representing workers in undertakings;

(h) rights of full membership in any form of co-operative;

(i) conditions of life, including housing and the benefits of social services and educational and health facilities.

3. Each Member should ensure the application of the principles set forth in Paragraph 2 of this Recommendation in all activities under the control of a public authority and promote its observance in all other activities by methods appropriate to national conditions and practice.

4. Appropriate measures should be taken, with the collaboration of employers' and workers' organisations and other bodies concerned, with a view to -

(a) fostering public understanding and acceptance of the above-mentioned principles;

(b) examining complaints that these principles are not being observed and securing the correction, by conciliation or other appropriate means, of any practices regarded as in conflict therewith.

5. Each Member should ensure that national laws and regulations concerning residence in its territory are so applied that the lawful exercise of rights enjoyed in pursuance of these principles cannot be the reason for non-renewal of a residence permit or for expulsion and is not inhibited by the threat of such measures.

\section{A Member may -}

(a) make the free choice of employment, while assuring migrant workers the right to geographical mobility, subject to the conditions that the migrant worker has resided lawfully in its territory for the purpose of employment for a prescribed period not exceeding two years or, if its laws or regulations provide for contracts for a fixed term of less than two years, that the worker has completed his first work contract;

(b) after appropriate consultation with the representative organisations of employers and workers, make regulations concerning recognition of occupational qualifications acquired outside its territory, including certificates and diplomas;

(c) restrict access to limited categories of employment or functions where this is necessary in the interests of the State.

7. (1) In order to enable migrant workers and their families to take full advantage of their rights and opportunities in employment and occupation, such measures as may be necessary should be taken, in consultation with the representative organisations of employers and workers -

(a) to inform them, as far as possible in their mother tongue or, if that is not possible, in a language with which they are familiar, of their rights under national law and practice as regards the matters dealt with in Paragraph 2 of this Recommendation;

(b) to advance their knowledge of the language or languages of the country of employment, as far as possible during paid time;

(c) generally, to promote their adaptation to the society of the country of employment and to assist and encourage the efforts of migrant workers and their families to preserve their 
national and ethnic identity and their cultural ties with their country of origin, including the possibility for children to be given some knowledge of their mother tongue.

(2) Where agreements concerning the collective recruitment of workers have been concluded between Members, they should jointly take the necessary measures before the migrants' departure from their country of origin to introduce them to the language of the country of employment and also to its economic, social and cultural environment.

8. (1) Without prejudice to measures designed to ensure that migrant workers and their families enter national territory and are admitted to employment in conformity with the relevant laws and regulations, a decision should be taken as soon as possible in cases in which these laws and regulations have not been respected so that the migrant worker should know whether his position can be regularised or not.

(2) Migrant workers whose position has been regularised should benefit from all rights which, in accordance with Paragraph 2 of this Recommendation, are provided for migrant workers lawfully within the territory of a Member.

(3) Migrant workers whose position has not been or could not be regularised should enjoy equality of treatment for themselves and their families in respect of rights arising out of present and past employment as regards remuneration, social security and other benefits as well as regards trade union membership and exercise of trade union rights.

(4) In case of dispute about the rights referred to in the preceding subparagraphs, the worker should have the possibility of presenting his case to a competent body, either himself or through a representative.

(5) In case of expulsion of the worker or his family, the cost should not be borne by them.

\section{SOCIAL POLICY}

9. Each Member should, in consultation with representative organisations of employers and workers, formulate and apply a social policy appropriate to national conditions and practice which enables migrant workers and their families to share in advantages enjoyed by its nationals while taking account, without adversely affecting the principle of equality of opportunity and treatment, of such special needs as they may have until they are adapted to the society of the country of employment.

10. With a view to making the policy as responsive as possible to the real needs of migrant workers and their families, it should be based, in particular, on an examination not only of conditions in the territory of the Member but also of those in the countries of origin of the migrants.

11. The policy should take account of the need to spread the social cost of migration as widely and equitably as possible over the entire collectivity of the country of employment, and in particular over those who profit most from the work of migrants.

12. The policy should be periodically reviewed and evaluated and where necessary revised.

\section{A. Reunification of Families}

13. (1) All possible measures should be taken both by countries of employment and by countries of origin to facilitate the reunification of families of migrant workers as rapidly as possible. These measures should include, as necessary, national laws or regulations and bilateral and multilateral arrangements. 
(2) A prerequisite for the reunification of families should be that the worker has, for his family, appropriate accommodation which meets the standards normally applicable to nationals of the country of employment.

14. Representatives of all concerned, and in particular of employers and workers, should be consulted on the measures to be adopted to facilitate the reunification of families and their co-operation sought in giving effect thereto.

15. For the purpose of the provisions of this Recommendation relating to the reunification of families, the family of the migrant worker should include the spouse and dependent children, father and mother.

16. With a view to facilitating the reunification of families as quickly as possible in accordance with Paragraph 13 of this Recommendation, each Member should take full account of the needs of migrant workers and their families in particular in its policy regarding the construction of family housing, assistance in obtaining this housing and the development of appropriate reception services.

17. Where a migrant worker who has been employed for at least one year in a country of employment cannot be joined by his family in that country, he should be entitled -

(a) to visit the country of residence of his family during the paid annual holiday to which he is entitled under the national law and practice of the country of employment without losing during the absence from that country any acquired rights or rights in course of acquisition and, particularly, without having his employment terminated or his right to residence in the country of employment withdrawn during that period; or

(b) to be visited by his family for a period corresponding at least to the annual holiday with pay to which he is entitled.

18. Consideration should be given to the possibility of giving the migrant worker financial assistance towards the cost of the travel envisaged in the preceding Paragraph or a reduction in the normal cost of transport, for instance by the arrangement of group travel.

19. Without prejudice to more favourable provisions which may be applicable to them, persons admitted in pursuance of international arrangements for free movement of labour should have the benefit of the measures provided for in Paragraphs 13 to 18 of this Recommendation.

\section{B. Protection of the Health of Migrant Workers}

20. All appropriate measures should be taken to prevent any special health risks to which migrant workers may be exposed.

21. (1) Every effort should be made to ensure that migrant workers receive training and instruction in occupational safety and occupational hygiene in connection with their practical training or other work preparation, and, as far as possible, as part thereof.

(2) In addition, a migrant worker should, during paid working hours and immediately after beginning his employment, be provided with sufficient information in his mother tongue or, if that is not possible, in a language with which he is familiar, on the essential elements of laws and regulations and on provisions of collective agreements concerning the protection of workers and the prevention of accidents as well as on safety regulations and procedures particular to the nature of the work.

22. (1) Employers should take all possible measures so that migrant workers may fully understand instructions, warnings, symbols and other signs relating to safety and health hazards at work. 
(2) Where, on account of the migrant workers' lack of familiarity with processes, language difficulties or other reasons, the training or instruction given to other workers is inadequate for them, special measures which ensure their full understanding should be taken.

(3) Members should have laws or regulations applying the principles set out in this Paragraph and provide that where employers or other persons or organisations having responsibility in this regard fail to observe such laws or regulations, administrative, civil and penal sanctions might be imposed.

\section{Social Services}

23. In accordance with the provisions of Paragraph 2 of this Recommendation, migrant workers and their families should benefit from the activities of social services and have access thereto under the same conditions as nationals of the country of employment.

24. In addition, social services should be provided which perform, in particular, the following functions in relation to migrant workers and their families -

(a) giving migrant workers and their families every assistance in adapting to the economic, social and cultural environment of the country of employment;

(b) helping migrant workers and their families to obtain information and advice from appropriate bodies, for instance by providing interpretation and translation services; to comply with administrative and other formalities; and to make full use of services and facilities provided in such fields as education, vocational training and language training, health services and social security, housing, transport and recreation: Provided that migrant workers and their families should as far as possible have the right to communicate with public authorities in the country of employment in their own language or in a language with which they are familiar, particularly in the context of legal assistance and court proceedings;

(c) assisting authorities and bodies with responsibilities relating to the conditions of life and work of migrant workers and their families in identifying their needs and in adapting thereto;

(d) giving the competent authorities information and, as appropriate, advice regarding the formulation, implementation and evaluation of social policy with respect to migrant workers;

(e) providing information for fellow workers and foremen and supervisors about the situation and the problems of migrant workers.

25. (1) The social services referred to in Paragraph 24 of this Recommendation may be provided, as appropriate to national conditions and practice, by public authorities, by approved non-profit-making organisations or bodies, or by a combination of both. The public authorities should have the over-all responsibility of ensuring that these social services are at the disposal of migrant workers and their families.

(2) Full use should be made of services which are or can be provided by authorities, organisations and bodies serving the nationals of the country of employment, including employers' and workers' organisations.

26. Each Member should take such measures as may be necessary to ensure that sufficient resources and adequately trained staff are available for the social services referred to in Paragraph 24 of this Recommendation.

27. Each Member should promote co-operation and co-ordination between different social services on its territory and, as appropriate, between these services and corresponding services in other countries, without, however, this co-operation and co-ordination relieving the States of their responsibilities in this field. 
28. Each Member should organise and encourage the organisation, at the national, regional or local level, or as appropriate in a branch of economic activity employing substantial numbers of migrant workers, of periodic meetings for the exchange of information and experience. Consideration should also be given to the exchange of information and experience with other countries of employment as well as with the countries of origin of migrant workers.

29. Representatives of all concerned and in particular of employers and workers should be consulted on the organisation of the social services in question and their co-operation sought in achieving the purposes aimed at.

\section{EMPLOYMENT AND RESIDENCE}

30. In pursuance of the provision of Paragraph 18 of the Migration for Employment Recommendation (Revised), 1949, that Members should, as far as possible, refrain from removing from their territory, on account of lack of means or the state of the employment market, a migrant worker regularly admitted thereto, the loss by such migrant worker of his employment should not in itself imply the withdrawal of his authorisation of residence.

31. A migrant who has lost his employment should be allowed sufficient time to find alternative employment, at least for a period corresponding to that during which he may be entitled to unemployment benefit; the authorisation of residence should be extended accordingly.

32. (1) A migrant worker who has lodged an appeal against the termination of his employment, under such procedures as may be available, should be allowed sufficient time to obtain a final decision thereon.

(2) If it is established that the termination of employment was not justified, the migrant worker should be entitled, on the same terms as national workers, to reinstatement, to compensation for loss of wages or of other payment which results from unjustified termination, or to access to a new job with a right to indemnification. If he is not reinstated, he should be allowed sufficient time to find alternative employment.

33. A migrant worker who is the object of an expulsion order should have a right of appeal before an administrative or judicial instance, according to conditions laid down in national laws or regulations. This appeal should stay the execution of the expulsion order, subject to the duly substantiated requirements of national security or public order. The migrant worker should have the same right to legal assistance as national workers and have the possibility of being assisted by an interpreter.

34. (1) A migrant worker who leaves the country of employment should be entitled, irrespective of the legality of his stay therein -

(a) to any outstanding remuneration for work performed, including severance payments normally due;

(b) to benefits which may be due in respect of any employment injury suffered;

(c) in accordance with national practice -

(i) to compensation in lieu of any holiday entitlement acquired but not used;

(ii) to reimbursement of any social security contributions which have not given and will not give rise to rights under national laws or regulations or international arrangements: Provided that where social security contributions do not permit entitlement to benefits, every effort should be made with a view to the conclusion of bilateral or multilateral agreements to protect the rights of migrants. 
(2) Where any claim covered in subparagraph (1) of this Paragraph is in dispute, the worker should be able to have his interests represented before the competent body and enjoy equal treatment with national workers as regards legal assistance. 